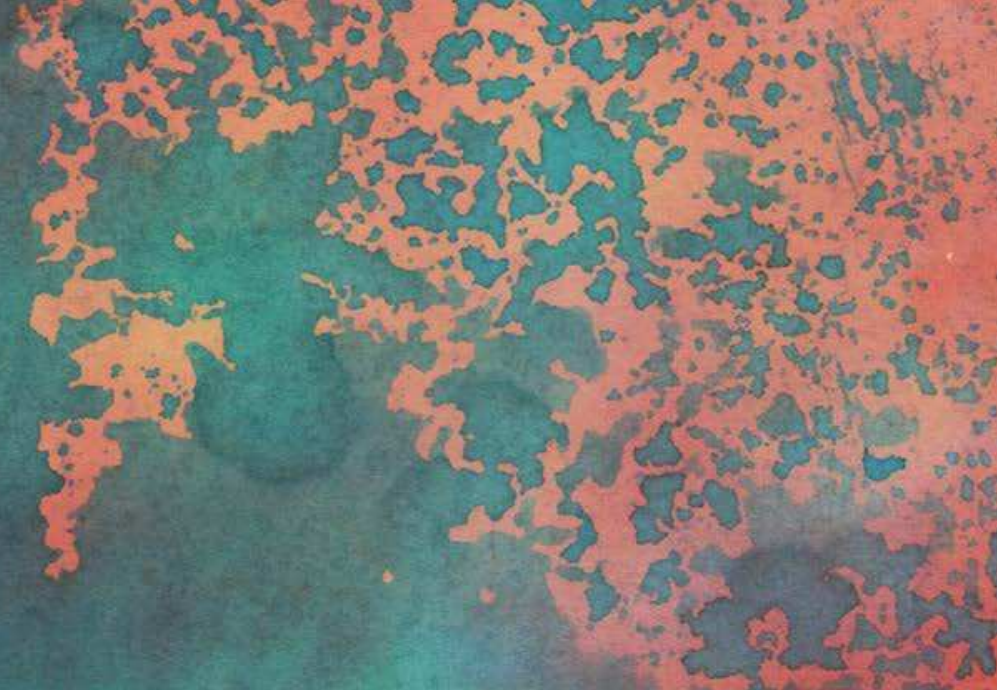

Routledge Studies in the Modern History of Africa

\title{
RETHINKING WHITE SOCIETIES IN SOUTHERN AFRICA
} 1930s-1990s

Edited by

Duncan Money and Danelle van Zyl-Hermann
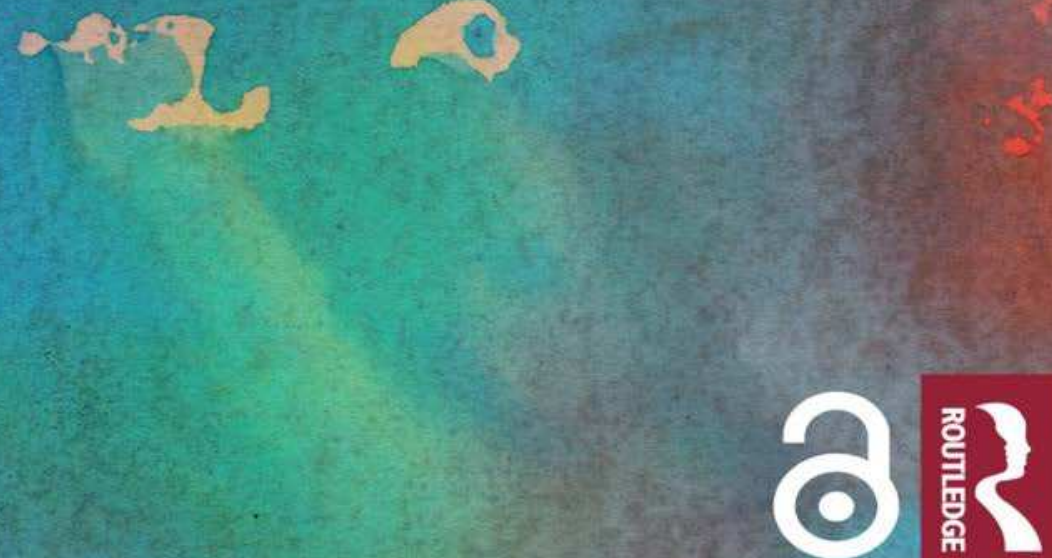


\section{Rethinking White Societies in Southern Africa}

This book showcases new research by emerging and established scholars on white workers and the white poor in Southern Africa.

Rethinking White Societies in Southern Africa challenges the geographical and chronological limitations of existing scholarship by presenting case studies from Angola, Mozambique, South Africa, Zambia and Zimbabwe that track the fortunes of nonhegemonic whites during the era of white minority rule. Arguing against prevalent understandings of white society as uniformly wealthy or culturally homogeneous during this period, it demonstrates that social class remained a salient element throughout the twentieth century, how Southern Africa's white societies were often divided and riven with tension and how the resulting social, political and economic complexities animated white minority regimes in the region. Addressing themes such as the class-based disruption of racial norms and practices, state surveillance and interventions - and their failures - towards nonhegemonic whites, and the opportunities and limitations of physical and social mobility, the book mounts a forceful argument for the regional consideration of white societies in this historical context. Centrally, it extends the path-breaking insights emanating from scholarship on racialized class identities from North America to the African context to argue that race and class cannot be considered independently in Southern Africa.

This book will be of interest to scholars and students of Southern African studies, African history and the history of race.

Duncan Money is a historian of Southern Africa whose research focuses on the mining industry. He is currently a researcher at the African Studies Centre, Leiden University, Netherlands and was previously a postdoctoral fellow at the International Studies Group, University of the Free State, Bloemfontein, South Africa.

Danelle van Zyl-Hermann is a historian of race and class in modern South Africa. She holds a $\mathrm{PhD}$ from the University of Cambridge and is currently a postdoctoral research fellow in the Department of History, University of Basel, Switzerland. 


\section{Routledge Studies in the Modern History of Africa}

This series includes in-depth research on aspects of economic, political, cultural and social history of individual countries as well as broad-reaching analyses of regional issues.

Themes include social and economic change, colonial experiences, independence movements, post-independence governments, globalisation in Africa, nationalism, gender histories, conflict, the Atlantic Slave trade, the environment, health and medicine, ethnicity, urbanisation, and neo-colonialism and aid.

\section{Forthcoming titles:}

Miscegenation, Identity and Status in Colonial Africa Intimate Colonial Encounters

Lawrence Mbogoni

Displaced Mozambicans in Postcolonial Tanzania

Refugee Power, Mobility, Education, and Rural Development

Joanna T. Tague

\section{Africans and the Holocaust}

Perceptions and Responses of Colonized and Sovereign Peoples

Edward Kissi

Photography and History in Colonial Southern Africa

Shades of Empire

Lorena Rizzo

Women's Lived Landscapes of War and Liberation in Mozambique Bodily Memory and the Gendered Aesthetics of Belonging Jonna Katto

Rethinking White Societies in Southern Africa

1930s-1990s

Duncan Money and Danelle van Zyl-Hermann

For more information about this series, please visit: www.routledge.com 


\section{Rethinking White Societies in Southern Africa}

1930s-1990s

Edited by Duncan Money and

Danelle van Zyl-Hermann 
First published 2020

by Routledge

2 Park Square, Milton Park, Abingdon, Oxon OX14 4RN

and by Routledge

52 Vanderbilt Avenue, New York, NY 10017

Routledge is an imprint of the Taylor E Francis Group, an informa business

(C) 2020 selection and editorial matter, Duncan Money and Danelle van Zyl-Hermann; individual chapters, the contributors

The right of Duncan Money and Danelle van Zyl-Hermann to be identified as the authors of the editorial material, and of the authors for their individual chapters, has been asserted in accordance with sections 77 and 78 of the Copyright, Designs and Patents Act 1988.

The Open Access version of this book, available at www.taylorfrancis.com, has been made available under a Creative Commons Attribution-Non Commercial-No Derivatives 4.0 license.

Trademark notice: Product or corporate names may be trademarks or registered trademarks, and are used only for identification and explanation without intent to infringe.

British Library Cataloguing-in-Publication Data

A catalogue record for this book is available from the British Library

Library of Congress Cataloging-in-Publication Data

A catalog record for this book has been requested

ISBN: 978-0-367-37642-0 (hbk)

ISBN: 978-1-003-00230-7 (ebk)

Typeset in Bembo

by Apex CoVantage, LLC 


\section{Contents}

Acknowledgements

Introduction: Rethinking white societies in Southern Africa, 1930s-1990s

DUNCAN MONEY AND DANELLE VAN ZYL-HERMANN

1 Workers called white and classes called poor: The "White Working Class" and "Poor Whites" in Southern Africa, 1910-1994

JONATHAN HYSLOP

2 Rhodesian state paternalism and the white workingclass family, 1930s-1950s

IVO MHIKE

3 Immigration and settlement of "undesirable" whites in Southern Rhodesia, c. 1940s-1960s

GEORGE BISHI

4 White people fit for a new South Africa? State planning, policy and social response in the parastatal cities of the Vaal, 1940-1990

BILL FREUND

5 Whites, but not quite: Settler imaginations in late colonial Mozambique, c. 1951-1964 
6 "Village Portugal" in Africa: Discourses of differentiation and hierarchisation of settlers, 1950s-1974

CLÁUdia CASTELO

7 Labour and mobility on Rhodesia's railways: The 1954 firemen's strike

NICOLA GINSBURGH

8 The dog that didn't bark: The Mufulira strike and white mineworkers at Zambian independence

DUNCAN MONEY

9 Social engineering and scientific management:

Some reflections on the apartheid public service and historical process

NEIL ROOS

10 White workers and the unravelling of racial citizenship in late apartheid South Africa 


\section{Acknowledgements}

The chapters collected in this book were presented and discussed during a February 2018 workshop, 'Poor, Precarious, White? Rethinking white societies in Southern Africa, 1930s-1990s', hosted by the International Studies Group at the University of the Free State, Bloemfontein, South Africa. The event was generously funded by a grant from the University of the Free State. For this, we would like to express our sincere gratitude to Lis Lange, then Deputy Vice Chancellor (Academic), for her immediate enthusiasm and support for the project, which were key to facilitating the financial, intellectual and organisational support it received. We were thrilled by the suggestion from Leanne Hinves, Routledge's editor for African Studies, to turn this intellectual project into a book and are grateful for the excellent support we have received from her throughout the process. This book has benefitted immensely from the intellectual generosity of colleagues in related fields. We were delighted when David Roediger, whose inspiring work played an important role in shaping the conception of this project, agreed to provide a Foreword to the book. Our heartfelt thanks to those colleagues who provided feedback on earlier drafts of the book. In particular, we would like to thank Ian Phimister, David Roediger, Deborah Posel and Rory Pilossof for their comments on the introductory chapter and extend a special thanks to Neil Roos for his intellectual input. We are also grateful for the suggestions received from the anonymous reviewers, which helped refine the book. We would like to warmly thank Jenny Lake and Ana Rita Amaral for their editorial and technical assistance in preparing the text. Finally, a special and heartfelt thank you to Ian Phimister. It has been a privilege and pleasure to benefit from his mentorship, encouragement and good humour, not to mention his expertise. This project is a product of and tribute to the convivial and supportive atmosphere which he facilitates at the International Studies Group. 


\section{Foreword}

A lot was on my mind when I made opening remarks at a workshop held at University of the Free State: 'Poor, Precarious, White? Rethinking white societies in Southern Africa, 1930s-1990s.' The gathering of scholars there and the ideas discussed and exchanged provide the basis for this impressive book. The hope here is that some of those thoughts will help frame the book and, especially, help us think about how critical studies of whiteness do and ought to travel. Of all my positive impressions from the conference - from Neil Roos's brilliant welcoming lecture to the important work being done by junior scholars - what perhaps struck me most was the inclusion of such great and varied work from beyond South Africa itself. Indeed, the conference and this book represent the fullest flowering of a study of whiteness based in workplaces, unions, and everyday life yet produced. The implicit lesson, that taking white society beyond a particular national framework leads to new questions and new answers, pervaded the conference and shapes my remarks here.

I taught at University of the Western Cape in 1991, a heady time in which that institution sometimes billed itself as UWC, the University of the Working Class. Its modestly named Marxist Theory Seminar sometimes drew upward of a thousand participants. I had not returned to South Africa in the intervening 27 years. My glib remark in explaining this absence professed a fear of being overcome by sadness for the fate of the South African revolution. But actually, we in the USA can't be judgmental about the state of anyone else's social movements or forget how much our failures condition what is possible everywhere. The truth is that I felt I had too little to say about South African struggles and regretted not opening and pursuing conversations regarding the white workers in both societies while there.

My most read book on whiteness, The Wages of Whiteness, came out during that stay in 1991, but I hardly spoke about it during my visit. There were good reasons. I arrived in South Africa, invited by a movement organization, near the end of the academic boycott. They and I very much saw the trip as focused on a local initiative - a people's history project at UWC, not a speaking or book-selling junket. I spoke in public very little and never outside the Western Cape. When I did speak, it was to (re)introduce C.L.R. James to South African 
audiences through Tariq Ali's obituary tribute film - which, I felt, was not a bad choice of priority.

But partly I felt overmatched speaking about whiteness in that time and place. One of my mentors, George Fredrickson, had set a high bar for learning much before writing and speaking to the comparative history of race in South Africa and the USA. If, through the work of Toni Morrison, Alexander, Saxton, Ted Allen, and James Baldwin, the explicit study of whiteness as a problem was finding a footing in US universities, the movement in South Africa had confronted sharply posed problems of race and class in such sophisticated and grounded ways that it seemed better for me to simply listen.

What I learned was critical. The insights of Luli Callinicos, for example, on the place of fiercely exploited European immigrant newcomers to South African mines generated ideas that would find their ways into my much later work on immigrants, whiteness, and "race management," which was done in concert with Elizabeth Esch. At one private but pivotal moment during the visit I tried out the term "so-called whites." Doing so was a reaction to widespread movement use of the term "so-called Coloured," a phrasing designed to underline the constructed and state-sponsored nature of such a category. From the time I had first heard it used by my friend and colleague Dennis Brutus, the late poet and activist, "so-called Coloured" seemed to get at something that also ran through the history of whiteness as a category. But veteran activists in the Cape urged caution. They rightly worried that to see a dominant social position as constructed would lead some to conclude that it was "merely constructed" at the very moment when it was crucial to emphasize that "the way to nonracialism was through race." The situated clarity of such an insight probably confirmed my reticence to speak in public about my (at that time) new work on whiteness. It was worth it.

And in general the stepping outside national, familiar frameworks is worth it. We see this in the first words of this book, which the editors use to address the vogue for explaining all manners of things from Brexit to Trump around the supposed existence and perfidy of a "white working class." The most forceful analyses of why this is a cul-de-sac and of how much whiteness operates to keep those whom its hails as white from joining working class mobilizations comes predictably from the USA and the UK. It is also the UK and its moment of danger that give us the recent work of Satnam Virdee, with its theorizing and historicizing of the "racialized outsider," a powerful contribution to the study of whiteness. That is to say that the critical study of whiteness turns on the making of claims of whiteness into a set of problems that is at once historical, moral, and political. Therefore, it is often in settings in which whiteness most urgently presents itself as a problem that analyses of it are sharpest and most energetic. It is no small wonder, then, that the most fully realized study of a movement of white workers and its limits, Jeremy Krikler's White Rising: The 1922 Rand Revolt and Racial Killing in South Africa, had the setting and timing that it did.

The best recent examples of a not only national but also transnational story that defamiliarizes the ways that whiteness is constructed comes in the work of 
Australian, especially those who are indigenous, scholars. In 2017, I attended a conference that convened in Queensland, "Race, Whiteness, and Indigeneity." That long and large event was conducted by the National Indigenous Research and Knowledges Network, which, alongside the Australian Critical Race and Whiteness Studies Association, has produced a critical whiteness studies uniquely shaped by the thought of racialized people for whom whiteness is an urgent problem. We in the USA - and, I think, scholars in South Africa imagine whiteness both as formed over and against a "Black" other and as rooted in enslavement, such that the Australian example should rightly arrest us. Without a large African presence or mass slavery, Australia has managed to (sadly) approximate the USA both in the depth of its commitment to white supremacy and, now again, in its brutality toward racialized outsiders. To think, as the indigenous Australian philosopher Aileen Moreton Robinson urges us to do so, of the indigenous peoples and their reverence for land as the equally important "Other" in the formation of whiteness is changing the face of US and Canadian scholarship.

It has potential to do so in other places. Fredrickson, for example, emphasized that race-makers in South Africa studied as models not only Jim Crow but also US reservation policies toward indigenous peoples. Fanon's searing insights in Black Skins, White Masks make the settler a focus. Such an emphasis perhaps maps awkwardly onto those in the white societies described in much of the present book - late-coming; separated in time both from conquest and, sometimes, even from the nationalities of original white settlers; and working alongside Africans who are themselves not necessarily local. But it repays consideration in a broader story, especially since, both in the USA and in South Africa, it so lurks in the dream work of collective white identities.

David Roediger 


\title{
Introduction
}

\section{Rethinking white societies in Southern Africa, 1930s-1990s}

\author{
Duncan Money and Danelle van Zyl-Hermann
}

White workers and the white underclass are (back) in the spotlight. The emergence and success of right-wing populist movements across Europe and North America are provoking debate and discussion about the attitudes and role of the "white working class", and all manner of political outcomes are attributed to this group. While definitions of this class are often unclear, it is generally regarded as a dynamic and reactionary force, largely motivated by hostility to "non-white" migrants, and when mobilised, it pushes politics and society to the right. ${ }^{1}$ For historians of Southern Africa, this contemporary discourse has unerring parallels with the historical experiences of white settler societies in the region, where working-class and poor whites have been regarded as the most ardent supporters and beneficiaries of the white minority regimes which were, one by one, overthrown during the latter part of the twentieth century.

Despite its recent prominence, the idea of a racialised working class is not a new one. Race and class have animated historians of Southern Africa perhaps more than any other issue. Yet in the literature on the region's history and in popular understanding, race and class are often treated as synonymous. Whites are regarded as a homogenous group which is uniformly wealthy and comfortable and atop a binary power structure, especially for later decades in the twentieth century. Indeed, as will be discussed in this book, existing scholarship on white workers and the white poor is overwhelmingly concentrated in the early twentieth century, with the implicit assumption that these categories of analysis are no longer valid for white societies in later periods. This book challenges this assumption and demonstrates its inaccuracy through new research on nonhegemonic whites in Southern Africa - that is, those whites who, due to their class position, were not firmly established in the dominant political, economic and social structures of the racial state from the 1930s to the 1990s. In this, we draw on the work of Ann Stoler, who argued that whites in colonial societies 'were neither by nature unified nor did they inevitably share common interests and fears', and that, far from being unimportant, internal divisions amongst whites shaped the practice and intensity of racial policies in different colonial settings. ${ }^{2}$ As the case studies in this book show, social class remained a salient and tension-producing element within white society throughout the century. Homogenising understandings of white societies not only are unconvincing 
and unhelpful for understanding race in the region but also actively obscure many of the social, political and economic complexities which animated the regimes in question. Moreover, the assumption that there were no real class divisions within white societies inadvertently reproduces the propaganda and myths propagated by white minority regimes: e.g. the classless volk of apartheid South Africa or the supposed egalitarianism of white Rhodesia.

In this book, early career and established historians offer a reassessment of Southern Africa's white societies as being often divided, fraught with tension and subject to constant state surveillance and intervention. This, we argue, reveals the workings and constructions of race and class in a wider sense. Indeed, there has been a lack of interest in the everyday experiences and agency of ordinary whites, how they lived, the jobs they performed, their relations with other whites, as well as with other "non-white" Africans, and how this was viewed by states. ${ }^{3}$ Similarly, the empirical grounding of much of the literature on white identity and power has been insufficient. ${ }^{4}$ Scattered work has been produced on this topic since the late 1990s, but it has not previously coalesced, and it has mostly been within a national framework with little scope for comparison. ${ }^{5}$ Yet as Jonathan Hyslop notes in this book, the economic integration of the Southern African region has long been established and recognised - not least by various moves towards and efforts at political integration since 1910. It is curious, then, that beyond the economic, historians have continued to approach states in the region as individual entities with hard and fast borders. ${ }^{6}$ This book argues for a regional approach and demonstrates how the history of white workers and the white poor reveal the social, political and cultural connections which, in addition to the economic, characterise the Southern African past.

In this book, class emerges in a variety of guises. Some authors - particularly those studying white labour movements - employ the concept in a materialist sense to identify those bound together by their position within workplace relations of production and by the organisational forms and the consciousness and collective action this engendered. Other contributors use class to refer to socio-economic indicators such as education, income and associated life chances - or the lack thereof. Still other authors adopt a cultural approach, attending to issues of taste, values, traditions and everyday life. In the various contributions, these different conceptions or emphases are seldom clear-cut; rather, they intersect with each other, producing a striking synergy both within and between chapters which would have been unthinkable some 30 years ago, when debates about class were last en vogue. This, we contend, is the result of two premises - the first has now become established; the second is what we are seeking to establish in this book. Firstly, it is now well established that class like race - is constructed and relational, and that for historians, the challenge is to examine what this meant in practice in various temporal and geographical contexts. The different approaches in this book all conceive of class in this relational sense. They also share, indeed demonstrate, a second premise: race and class cannot be considered independently - we cannot talk about race without talking about class. Path-breaking scholarship on "whiteness" and racialised 
class identities emerging in the American academy in the 1990s established this understanding in the United States. David Roediger, a central figure in this 'new labour history', argued that, for the USA, 'working class formation and the systematic development of a sense of whiteness went hand in hand'. ${ }^{7}$ Drawing on these insights, this book seeks to establish this claim for the Southern African context. By concentrating on white workers and the white poor, it seeks to counter the tendency in existing literature which unproblematically associates white skin with privilege or even defines white identity as power and privilege. ${ }^{8}$ The societies considered in this book were all organised along racial lines, and those living in them who were racialised as white certainly enjoyed related privileges. Yet as the case studies presented here clearly show, whites were not always privileged in the same way. The social histories of whites presented in these chapters reveal that there were multiple and different kinds of whiteness across the region, and these were inextricably connected to the manner in which different whites were classed. In parallel to familiar representations of colonial- and apartheid-era Southern Africa's bourgeois white societies, living in the lap of luxury on the back of black exploitation, there remained elements of a white underclass, a working poor and a consciously blue-collar contingent. Within these groups, too, there were important variations. As will be shown, the white copper miners in Northern Rhodesia buying yachts with hefty pay cheques lived very different kinds of lives from those of recently transplanted Portuguese peasants eking out an existence as subsistence farmers in Angola and Mozambique.

Despite such variations, there were important points of commonality within the region. In contrast to the emphasis placed on the invisible or unmarked nature of whiteness in white majority contexts such as North America or Europe, different classes of whites in Southern Africa were all subject to what has been termed the 'hypervisibility of white skin in Africa'. ${ }^{9}$ In all the societies considered in this book, whites were minorities, often small minorities, making their presence glaringly obvious. Yet power and privilege did not always automatically follow from the presence of white skin. As Deborah Posel has shown, for instance, South Africa's 1950 Population Registration Act defined a white person through appearance, as well as through markers pertaining to lifestyle and social acceptance. ${ }^{10}$ We argue here that the meanings and consequences accompanying white skin were always historically contingent, constructed, contextual and entangled with class. In other words, in order to move beyond a one-dimensional understanding of white settler society and the interracial dynamics which underlie white minority rule, we need to consider that power, status and hegemony were not necessarily fixed, secure or self-evident for all those raced as white. While in the context of a racially organised society white skin certainly bestowed a significant measure of dominance and privilege, it could also attract the disciplinary power of the state in ways which resonated with state attitudes towards and regulation of the black majority. As this book shows, the manner in which historical subjects were raced was very much contingent on how they were classed. 
The research presented here investigates how race was made and sustained in practice. The case studies presented here are drawn from the former Southern African territories of the British Empire, most prominently South Africa and Rhodesia, as well as Portugal's African colonies. Of course, these are not exhaustive, and the absence of scholarship on Botswana, Katanga or Namibia reflects the state of this field of historical inquiry and points to crucial future avenues of inquiry. We hope that the present book will encourage further research and test the validity of the arguments advanced here against case studies drawn from elsewhere in the region.

Centrally, the new research presented in this book demonstrates the persistence of class amongst Southern African whites and how this was entangled with the ways race was made and sustained in practice. In contrast to established understandings, white workers and poor whites were features of the colonial landscape throughout the twentieth century, right up to the last days of minority rule, and, indeed, beyond. Where they were less visible due to the privileges, protection and opportunities afforded within these racist contexts, they remained present nonetheless, and their upwards social mobility was typically much less solid than has been assumed. Social distinctions within the white population - whether based on status, ethnicity or income - therefore remained a feature of Southern African society throughout the colonial period. Minority rule did not produce a solid block of equal, race-based privilege. And as the next section shows, white colonial regimes were ambiguous at best and hostile at worst to the subaltern whites it perceived to lurk and loiter around the edges of race-based societies.

\section{Social history and suitable subjects in Southern Africa}

Southern Africa, and South Africa in particular, has a rich tradition of social history.This scholarship emerged in a particular politicised context, namely the revival of black trade unionism, student revolts and the great upsurge in resistance to apartheid in the 1970s. As a result, many historians at the time pursued an openly, entirely justifiable political aim to link historical research with these movements and make it available to those engaged in these struggles. ${ }^{11}$ As a result, their work had relatively little to say about whites beyond highlighting the racialised power blocs produced by the capitalist political economy of the Southern African region. Other scholars, similarly observing the grassroots activism of the liberation struggle, sought to incorporate the agency of ordinary people in analyses of the development of racial capitalism. This gave rise to a tradition of social history scholarship which included important work on white societies focused on the turn of the twentieth century. The tumultuous clashes between the white labour movement and the South African state, culminating in a full-blown armed insurrection in 1922; industrial diseases that decimated the ranks of the first generation of white mineworkers; rural poverty that forced Afrikaners from the land and into the cities; and the ferment of radical and revolutionary politics amongst working-class whites offered rich 
subjects for historians. ${ }^{12}$ Particularly noteworthy is Robert Morrell's White but Poor, an edited collection which is very much a predecessor to this present book. In his introduction to Morrell's book, Bill Freund (also a contributor to this book) argues that white society in South Africa 'consists and consisted of deeply differentiated, sometimes antagonistic classes whose fragile unity under a segregated society represented a difficult political achievement'. ${ }^{13}$

This argument is taken up and extended in this book. In doing so, we seek to amend two interrelated limitations suffered by the existing scholarship: one chronological and the other geographic. The first is that it is largely concentrated in the late nineteenth century and early decades of the twentieth century in the context of the mineral revolution and associated processes of industrialisation and urbanisation. ${ }^{14}$ There are only a handful of studies which extend our knowledge on the topic beyond this period..$^{15}$ The neglect of white labour and the white poor as historical subjects in South Africa after the 1940s can be attributed to assumptions about the "solving" of the poor white problem following the so-called civilised labour policy enacted by the Nationalist-Labour Pact government from 1924 and the success of the National Party's (NP) apartheid policies in bringing about the embourgeoisement of the white population after $1948 .{ }^{16}$ State intervention in the form of racialised employment protection, social security, and the harnessing of the post-war economic boom primarily for the benefit of whites has given rise to the implicit assumption in the literature that white workers and the white poor effectively ceased to exist after the mid-twentieth century. One corollary of this was that scholars no longer deemed the analysis of white societies in these terms valid. Scholarly attention for the period following the 1940s, therefore, turns elsewhere, and little attention is paid to the lives of ordinary whites in these societies until the postapartheid period. Since the 1990s there has been a flurry of work, primarily by anthropologists and sociologists, on poor whites and interest, bordering on fascination, in the media with the so-called re-emergence of white poverty mostly in South Africa but also in Zimbabwe. ${ }^{17}$ This demands the historicisation of white precarity and the probing of the fragility of race-based privilege.

This is not to deny that the lives of whites across Southern Africa underwent significant changes in the twentieth century. Developmentalist, interventionist states did improve the living standards of their white inhabitants. In South Africa, many of those regarded as poor whites and unskilled white workers enjoyed greater material prosperity and higher incomes, along with attendant shifts in status and consumption patterns. The numbers of whites also rose markedly, as the economic boom drew hundreds of thousands of European immigrants to Angola, Mozambique, Northern Rhodesia and Southern Rhodesia. The various political regimes also sought to attract new settlers in the post-war period to bolster their position. This period, therefore, also saw shifts in the nature of white societies. With the exception of white workers on the Northern Rhodesian Copperbelt, the powerful white labour movement of the early twentieth century was either repressed or co-opted by the state. In South Africa, following the bloody suppression of the Rand Revolt, the 1924 Industrial Conciliation 
Act incorporated white trade unions into state structures and 'marked the end of effective white labour militance'. The same occurred in Southern Rhodesia following the passing of the 1934 Industrial Conciliation Act, which was closely modelled on South African legislation. ${ }^{18}$ Repression predominated elsewhere. The army was used to break the 1923 strike by white railway workers in Angola, while in Mozambique the combative white workers' movement was crushed after a military coup in 1926 installed a dictatorship in Portugal, and the last major strike by white workers there took place in $1932 .{ }^{19}$ In Belgian Congo's Katanga province, Union Minière du Haut Katanga, the mining company which dominated the region, successfully suppressed the nascent white labour movement on the mines in the early $1920 \mathrm{~s}^{20}$

In much of the existing scholarship, it appears as though white labour movements' transformation from militancy to quiescence during the 1920s resulted in the assumption that whites ceased to be workers, as they no longer offered a serious or sustained challenge to capital. One account, of Wankie Colliery in Southern Rhodesia, for instance, argued that although white miners had taken serious strike action in the 1920s, by the 1950s there was no industrial unrest as 'almost all settlers saw themselves as whites rather than workers'. ${ }^{21}$ This argument bears more than a passing resemblance to the historical orientation of the South African Communist Party. The Communist Party had initially drawn its support from white male workers, which it regarded as the only real proletarians in South Africa. Yet following the 1922 Rand Revolt and the subsequent shift of white working-class loyalties to the Pact Government, the party reorientated itself towards African workers and their organisations. ${ }^{22}$ Historians seem to have followed suit, and the historiography on the period after the 1940s discusses a working class that is uniformly black. ${ }^{23}$ This perspective characteristic of traditional or 'old' labour history writing - conflates the history of white workers' organisations with the history of white workers themselves. ${ }^{24}$ Beyond developments in labour specifically, the long post-war economic boom is understood to have fundamentally altered the nature of white societies. Scholarship emerging in the 1970s, therefore, not only advocated a focus on black labour but also debated the role and questioned the very existence of the white working class in South Africa beyond the early decades of labour militancy. Scholars in this debate - in which white miners generally stood in as proxies for the wider white working class - placed a heavy emphasis on class structure and concluded that most, if not all, white workers should be regarded as part of the middle class; thus, they were best categorised as 'white wage earners', according to Robert Davies, or the 'new middle class', according to Harold Wolpe. ${ }^{25}$ These designations were regarded as more appropriate both because whites predominately performed supervisory jobs and because the high wages paid to white workers were dependent on low wages for African workers, with the former extracting surplus value from the latter. The number of whites still employed as productive workers, these scholars argued, were so few that they could usefully be considered part of a broader white group outside the working class. ${ }^{26}$ 
The second limitation of the existing scholarship is geographical: it concentrates overwhelmingly on South Africa and, within South Africa, on the Witwatersrand. White communities in Angola, Katanga, Mozambique, Namibia, Northern Rhodesia and Southern Rhodesia have received comparatively little attention. Only two of the nine chapters in White but Poor, for instance, are not on South Africa. Morrell notes that he unsuccessfully tried to solicit chapters on the white poor elsewhere in the region to generate comparative insights. ${ }^{27}$ What scholarship does exist largely conforms to the chronological limitations described earlier in this section. ${ }^{28}$ One noteworthy exception is the relatively substantial scholarship on whites and whiteness in post-colonial Zimbabwe, despite the comparatively small size of this population. ${ }^{29}$ Here, however, the focus has overwhelmingly been on white farmers, and issues of white selfrepresentation and notions of belonging. The catalyst for this literature was Zimbabwe's chaotic and often violent land reform programme in the 2000s, which seized control of white-owned land and thrust the country's white farmers into international prominence as easily the most discussed white population in the entire region. ${ }^{30}$ The experiences of white farmers are typically taken to be characteristic of whites in the country - though they constituted only a small proportion of a white population that has long been predominately urban $^{31}$ - and there is little in this literature on white workers and the white poor. Indeed, discussions of divisions within the white population largely focus on attitudes towards and integration with black Africans. ${ }^{32}$

One reason why South Africa has attracted by far the most scholarly attention is that it contained the bulk of the region's white population. To be sure, numbers of whites elsewhere were not insubstantial. At the peak of their respective white populations, in the mid-1970s, there were 280,000 whites in Southern Rhodesia, an estimated 335,000 whites in Angola and some 200,000 whites in Mozambique, though whites never constituted more than about 5 per cent of the total population in any of these states. ${ }^{33}$ Yet South Africa's white population exceeded these by far, with over 4.1 million in 1974, an estimated 17 per cent of the total population. ${ }^{34}$ The white population continued to grow until the early 1990s.

Although South Africa had by far the largest white population, the numbers do not tell the full story. Whites in Southern Africa were highly mobile, both within and beyond the region. South Africa's large white population did not remain within the country's borders. Afrikaners were to be found in Angola, Namibia, Northern Rhodesia and Southern Rhodesia. ${ }^{35}$ Many whites in Southern Rhodesia were born in South Africa, while others had spent time living there, and large numbers of whites came into Rhodesia from Angola and Mozambique when Portuguese colonial rule collapsed in $1975 .{ }^{36}$ Considerably larger numbers of Portuguese whites arrived in South Africa via Angola and Mozambique. ${ }^{37}$ Many white workers also habitually crossed borders in search of work. It was not unusual for a white miner working on the Rand to also have worked on the Northern Rhodesian Copperbelt and vice versa, and white railway workers often worked across the railway network linking South 
Africa, Northern and Southern Rhodesia and Mozambique. One consequence of constant movement is that the figures for the total white population in any given territory do not accurately reflect the numbers of whites who had actually lived there, as beyond South Africa these relatively low figures masked high rates of immigration and emigration. For instance, an average of 10,207 whites arrived in Southern Rhodesia every year between 1955 and 1979 (255,175 in total), but the total white population in 1979 was only $228,583 .{ }^{38}$ Clearly, white settlers across Southern Africa were often not settled at all. In some ways, physical mobility constituted another form of race-based privilege, and this mobility of whites in the post-war period contrasted sharply with the intensifying control to which Africans were being subjected. At the same time, contributions to this book show that for many whites, physical mobility represented a precarious and unstable unsettledness.

Debates surrounding the role and position of white labour and scholarship on early-twentieth-century white working-class lives took place in a context in which white labour formed an important political constituency in Southern Africa. While this is no longer the case today - for either this specific class or this race - the arguments offered by scholars such as Davies and Wolpe remain unsatisfactory, and the contributions in this book forcefully demonstrate how and why class remained a salient feature within white society. White miners in South Africa, who featured so prominently in scholarly debates, saw their wages increase markedly during the early apartheid period. Indeed, the gap between white and African wages widened significantly in the course of the 1950s and 1960 s. ${ }^{39}$ Yet whatever upwards mobility these workers enjoyed as a result of their inflated wages, their material and subjective privilege remained dependent on state patronage. This became clear in the late 1970s, when labour unrest and economic instability forced the apartheid government to consider reforming race-based labour legislation. As Danelle van Zyl-Hermann shows in this book, white workers vehemently resisted reform efforts. Blue-collar workers in both the mining and the steel industries consciously defined their collective identities and interests in this regard as being rooted in the workplace, and they articulated this as being opposed not only to the African workers whose labour competition they feared, but also to white employers and the capitalist exploitation from which they demanded state protection. Even in the hey-day of apartheid, white identities remained classed and closely linked to work. Similar arguments are made in Nicola Ginsburgh's chapter on white railway workers in Southern Rhodesia and Duncan Money's chapter on white mineworkers in Northern Rhodesia, two groups whose identities and defence of their perceived interests were based on the work they performed. Both these chapters and Bill Freund's chapter on white workers in South Africa's state-owned industrial enterprises point to the continued recruitment of skilled white workers from Europe. Clearly, a demand for such workers and their skills remained in the region's economies. Most of these workers continued to perform the same kinds of jobs in Southern Africa that they had done on mines, railways and steel plants in the UK and elsewhere. 
The most obvious form of subordination and marginalisation which stratified white societies in the region was the continued presence of poor whites. Typically, stratification in white societies is examined along national and ethnic lines - for instance, in South Africa, marginalised whites are almost exclusively cast as Afrikaners $^{40}$ - but this book moves beyond such conceptualisations. ${ }^{41}$ Contributions from Cláudia Castelo and Caio Simões De Araújo detail the rural settlement schemes whereby poor and often illiterate peasants from metropolitan Portugal were moved to newly-created, isolated agricultural communities in Angola and Mozambique to bolster Portuguese colonial rule. There was little materially that distinguished these white peasant farmers, disliked and mistrusted by other whites and the colonial authorities, from the Africans alongside whom they lived. George Bishi's chapter on "undesirable" white immigrants in Southern Rhodesia shows how the state regarded the maintenance of a certain level of material prosperity as a core component of white identity and continually intervened to remove those who failed to meet the proscribed and shifting material standards of white "desirability". Indeed, persistent state intervention directed at whites is an important indication that the perceived problem of "poor whiteism" endured. In Southern Rhodesia, fears that children of impoverished white families would "degenerate" prompted extensive state control over white families that, as Ivo Mhike's chapter explains, undermined the state's guiding ideology of white supremacy. Similarly, Neil Roos's chapter on white public servants in South Africa explores how a huge expansion of the public service sought to provide jobs for lower-class whites, but these same public servants were mistrusted by white elites and hence were carefully monitored, disciplined and subjected to intrusive scientific management techniques.

Together, these chapters demonstrate the class dimensions of racial power: despite their considerable privileges, many whites lacked much of the mastery and dominance associated with white power in colonial Africa. Their fate was largely decided, and their agency limited, by others. Both white workers and the white poor occupied a position within white society which was often an ambiguous or uneasy one, and their actions, individually or collectively, could upset established racial boundaries or destabilise white societies.

It should be apparent from this section that there is an important distinction to be made between white workers and the white poor, which are too readily conflated in the existing literature. Many white workers, for instance, were relatively wealthy, and as will be seen, the kinds of histories that can be written about these two groups are often very different. At the same time, boundaries between the two groups were not hard and fast, and there are some instances where a certain historical trajectory might connect the two groups. For one, as a result of sustained state intervention, the white poor often became white workers. Freund, for instance, explores how racially preferential employment in new state-owned industries in South Africa was seen as a solution to white poverty. Many white workers themselves feared not only that this process of upwards mobility could be reversed but also that they would once again slip 
into the indignity of being "poor whites". This was the case, for instance, for the semi-skilled white mineworkers discussed by Van Zyl-Hermann, who saw the spectre of white poverty lurking menacingly about the discussions surrounding labour reform in late-apartheid South Africa.

Despite these historical connections, it is helpful to maintain a distinction between white workers and the white poor, not least because they appear in the historical record in different ways. Sources produced by the former, especially material relating to work, are relatively easy to discover. White workers often gave evidence to government enquiries, were quoted regularly in newspaper articles and formed organisations which generated their own, often substantial, archives. Ginsburgh, then, can draw upon publications produced by the whitesonly Rhodesia Railway Workers' Union along with newspaper interviews with white trade unionists. Money, similarly, utilises documents produced by striking white mineworkers, along with records of negotiations in which white mineworkers made their demands forcefully clear. The white poor, on the other hand, only infrequently produced sources about themselves - Will Jackson has noted, 'the voices of poor whites in their own words' have been 'elusive'. ${ }^{42}$ This was a category of people which others wrote about - usually in a disapproving, interventionist manner. Mhike, for instance, provides rich information on state efforts to discipline and rehabilitate indigent whites, but there is little surviving information on how the white poor themselves regarded such state interventions. Castelo's chapter presents a similar reality, where there is abundant evidence on how state officials and institutions regarded Portuguese peasants, but these peasants left few impressions about how they saw themselves and their place in this new setting. Unlike white workers, the white poor were scattered and atomised in this period and did not form their own organisations. Where the white poor gathered in any numbers - or, more often, where they were gathered by state intervention, such as in Angola's colonatos - they were subject to close supervision and control, which generated a different kind of documentary record than that produced by white workers.

The kinds of sources which are available has consequences for the kind of histories which appear in this book. Our contributions focus on the relationships between whites and the state, to the unavoidable neglect of histories of personal spaces, families, intimacies and emotions, though Mhike's chapter touches on some of these. The main regrettable absence is an in-depth consideration of gender. Roos's chapter describes how the patriarchy of Afrikaner nationalism both enlarged and limited employment opportunities available to white women, in a manner resembling the employment of black workers, where white labour shortages were evident - but closer attention needs to be paid to the experiences and agency of white female workers in their relations to the state..$^{43}$ These important histories would reveal much about the internal life of Southern Africa's white societies. It would, however, entail a very different project from the one we have attempted here and would have to grapple with the problem of sources. It is possible that historical biography, which Hyslop utilises in his contribution, could be a way forward for these kinds of histories. 


\section{Emerging themes}

The following chapters present new scholarship on white societies in colonialera Mozambique, Angola, Zambia, Zimbabwe and South Africa. The chapters are arranged chronologically, rather than by country, in order to facilitate the regional conversation and render visible continuities and discordances throughout the period under investigation which have otherwise been overlooked. The first chapter sees Jonathan Hyslop suggesting a trinity of analytical axes for approaching the history of white workers and impoverished whites in Southern Africa. Historians would do well, Hyslop argues, to employ comparison between states, seek connections across the region and consider contemporaneous global ideologies and events. This would serve to revise existing understandings of and reveal new insights into white society in Southern Africa. These methodological propositions are born out in a number of the empirical case studies presented in the remainder of the book. In this regard, a number of themes come into focus.

\section{Class-based distuption in white societies: Indocility and transgression}

In Southern Africa, as in other settler colonial contexts, white rule depended on a sharply delineated boundary between colonisers and colonised. This was upheld by the mythology of fixed racial categories, a fiction maintained only by conscious and determined interventions on the part of political and social elites. Existing scholarship has demonstrated how, in the late nineteenth and early twentieth centuries, poor and working-class whites were the main objects of elite anxieties. Their poverty as well as their proximity to black Africans - living alongside, performing the same kinds of work, maintaining social relations with or, perhaps more than anything, having sex with - provoked acute fears of racial degeneration and the disruption of the carefully constructed racial boundaries on which white rule depended. ${ }^{44}$ But these themes fade from scholarship on the latter part of the twentieth century. As Southern Africa basked in the glow of the post-war economic boom, its white societies are generally considered to have attained uniform wealth and displayed unvarying support for state policies. White societies, it seemed, had settled into comfortable homogeneity, without significant subsections causing concern and requiring intervention.

Yet a number of contributions in this book demonstrate the persistence of class-based racial disruption throughout the century and across the region. Whether this persistence related to perception (the gaze of the state and elite anxieties) or to reality (the agency of nonhegemonic whites) is not always clearly distinguishable in the available sources. But both clearly continued to characterise the region and saw class and race intersect with age, ethnicity and gender. Social interaction between white and black continued to raise concerns. Ivo Mhike's chapter tracks the manner in which white working-class children playing with their African counterparts, or young white petty criminals consorting with blacks, attracted the attention of police and welfare officers 
in inter- and post-war Southern Rhodesia and marked these white youths out for state intervention. The financial insecurity and hence assumed moral fallibility of their home lives was often blamed for their disruptive behaviour. Many were placed in single-sex corrective institutions. But these were not guaranteed to turn out model white citizens. As Mhike shows, white youths resisted state intervention, often absconding from rehabilitative schools to return to their previous ways of life. George Bishi identifies workers of Italian, Greek and Portuguese origins as another section of Southern Rhodesian society which was marked out as potentially threatening racial boundaries. In the post-war context, the proximity in which these immigrants lived and worked with Africans was identified as disruptive by the state. Revealingly, this was compounded by their non-British origins - their ethnicity, evidently, identified them as potentially racially nonconformist, amplifying the threat they posed.

In direct contrast to fears aroused by multiracial mixing and congeniality, however, there was another, seemingly contradictory way in which white workers and the white poor were seen to threaten the established racial order. This was revealed in the course of the century. As local imperatives and international pressures shifted, white authorities became increasingly concerned about lower-class whites' ostensible propensity for hostility towards Africans. While earlier colonial histories readily provide an abundance of examples of crude and violent racism amongst political and social elites, racial prejudice - at least in public life - became more subtle in Southern Africa by the mid-twentieth century. For Southern Rhodesia, for instance, Alison Shutt has shown how perceived manners and social etiquette became an important part of white identity. ${ }^{45}$ Politicians in the Central African Federation stressed the policy of "partnership" between whites and Africans, Portugal championed the idea of a multiracial empire, and South Africans reformulated apartheid as the ostensibly equal but distinctly separate development of the country's different "nations". White elites across the region came to regard open expressions of racism as impolite and uncivilised - and potentially dangerous to political arrangements which cloaked continued white power in a veneer of nonracialism.

In this context, racial tensions were blamed on the actions of white workers and the white poor. These lower-class whites were seen to inflame racial friction by their proximity to Africans, whom they were thought to abuse, be violent towards and compete with economically, thereby frustrating Africans' aspirations. One contemporary apologist for the Central African Federation claimed racial tensions arose because 'the attitude of the British artisan towards the black people is very much less liberal than that of other grades of [white] society' and due to the behaviour of white women like 'the mechanics' wife, who has never had a servant' and so treated servants with 'downright contempt' ${ }^{46}$ In this book, Caio Simões de Araújo details similar complaints by white settler elites in Portuguese Mozambique that poor whites mistreated and antagonised Africans, disrupting the colony's supposedly harmonious race relations. Here, the colonial vision of whites as a superior race guiding Africans towards civilisation and development was seen to be imperilled by those whites 
who lived and worked alongside Africans. Similarly, in South Africa, the intransigence of the white workers described by Van Zyl-Hermann and their hostility towards Africans was blamed for slowing economic growth and antagonising African workers.

The idea that both sociable contacts as well as overt hostility by poor and working-class whites disrupted racial hierarchies reveals the manner in which social distance from racial others was a necessary component of white identity throughout this period, even if the manner in which this was demonstrated or lived changed over time. Throughout, however, white workers and the white poor were regarded as unable to maintain proper relations with Africans. As one "liberal" colonial civil servant in Northern Rhodesia put it:

The basic difference between us and the settlers is probably that we feel that Europeans, as rulers and with their more absolute moral standards, have, by the principles of their own religion and culture, a responsibility towards the under-privileged. ${ }^{47}$

This is not to say that these nonhegemonic whites jettisoned their privileged position in the racial state. The disruption they caused was more in the line of indocility than transgression. This argument is most clearly advanced in the chapter by Bill Freund. The South African parastatals Iscor and Sasol formed a key part of the "civilised labour" policy first championed by the Pact Government in the 1920s, and continued by the National Party after 1948. But civilised labour was not simply a matter of employing white workers and paying them higher wages to maintain a certain standard of living. The workers themselves, Freund contends, needed to be "civilised" - disciplined and regulated to adopt certain ideas of productivity, temperance and respectability suited to the interests of the racial state and urban industrial capitalism. The company towns of the Vaal built to accommodate blue-collar families reflected such top-down efforts to create civilised white labour. But 'regimentation bred rebelliousness', Freund argues, and many white workers sought to escape the 'dictates of civilised labour' by living outside the parastatal towns in peri-urban spaces, supplementing their incomes with small-scale farming or illegal business activities, both of which involved employing or working with Africans. These disruptions did not, however, amount to actually transgressing social boundaries upholding the racial state. Rather than transgression, Freund argues, such white workingclass practices may be more accurately described as indolence. In other words, the decision of some - although hardly all - white workers to forsake the world of "civilised" working-class living for the physical and racial borderlands did not necessarily amount to a forsaking of their racial privilege and power, but a choice for exercising it on their own terms.

Indeed, throughout this book, there is really only one example of an individual who transgressed the boundaries of whiteness - Charles Taylor, the militant trade unionist who was deported from Southern Rhodesia in 1954 for instigating a strike on the Rhodesian Railways. As Nicola Ginsburgh relates, Taylor openly 
criticised the treatment of coloured prisoners by the South African authorities, defended African workers' right to strike, and expressed his lack of concern at borrowing money from an African or allowing his daughter to enter into an inter-racial marriage. In the eyes of the colonial authorities, these views demonstrated a dangerous lack of racial propriety on Taylor's part. Yet Taylor is clearly an exception - one of a handful of transgressions recorded in existing scholarship on white racial states of working-class individuals rejecting or renouncing whiteness. ${ }^{48}$

As this book demonstrates, indocility was much more widespread than existing literature recognises. Duncan Money shows that the Copperbelt's white mineworkers were a truculent, disruptive presence on the mines, quick to defend their autonomy against white managers. Yet even at their most militant, they did not question or transgress racial boundaries, and sought to maintain their status as a racially bound class. Neil Roos similarly highlights instances of indocility and even occasional defiance amongst lower-class Afrikaner civil servants, despite their superiors' efforts to subject them to disciplinary interventions designed to eliminate dissidence, tighten ideological adherence and produce conformity. Roos offers examples of low-level officials acting compassionately across the colour line, of nurturing relationships of trust and even accepting support from blacks. Such instances demonstrate the limits of state's capacity to manage whites lower down the public service hierarchy, and reveal the agency of white subalterns in a manner which challenges existing certainties about apartheid society. At the same time, there is no evidence that such moments of indocility and defiance ever amounted to outright opposition to the racial state. In fact, Roos argues, the public service simultaneously provides a lens unto the complicity of lower-class whites in the production and maintenance of apartheid society through their participation in the institutions of the state.

White workers and poor whites therefore continued to threaten racial hierarchies throughout the twentieth century. The fact that this involved perceived disruption as well as real indocility, but not actual transgression or sustained opposition to reigning racist practices, codes and behaviours, opens up the possibility of rethinking racial interaction and identities in the racial state. A focus on lower-class white agency reveals race as functioning not in terms of clear dividing lines or borders, as the mythology held, but in terms of zones or spaces in which working-class realities produced room for manoeuvre and space for ambiguity.

\section{Discipline, rehabilitation - and the failure of state interventions}

From the preceding discussion on class-based disruption, it is clear that both analytically and methodologically, nonhegemonic white agency cannot be examined without attention to the role and nature of the racial state. A significant body of literature on Southern Africa's white-ruled states around the turn of the twentieth century has focused on efforts to demolish racially mixed 
urban areas, provide work or welfare for whites, assign children to their supposed proper racial group, prevent Africans from owning property, and prohibit interracial intercourse - all motivated by the desire to uphold white power. ${ }^{49}$ This revealed official uneasiness about whether whites' ostensibly innate racial superiority - the legitimising basis for white minority rule - was indeed grounded in biological fact. But existing literature suggests that, by the middle of the century, unruly white elements within Southern Africa had been successfully uplifted and co-opted into racial capitalism, and state attention could shift more intently to the suppression or appeasement of African demands. As already indicated, a number of contributions in this book challenge this view by tracking continued state efforts to discipline and rehabilitate lower-class whites perceived to be disrupting, or threatening to disrupt, the racial order. These continuities reveal the constructed, and historically and contextually contingent nature of race, even during the heyday of colonial power: "whites" in Southern Africa were not a natural category - they were only white in as far as they were socially constructed as such. The process of drawing racial boundaries, Hyslop argues, was crucial to how states constituted themselves. White workers and the white poor disrupted ostensibly self-evident racial hierarchies and categories, and states' responses to such disruptions reveal the variety of forms the constitution of the racial state took.

Welfare and punitive measures such as those discussed by Mhike in the Southern Rhodesian context were part of a broader repertoire of interventionist racial disciplining. In South Africa, the apartheid state had vast resources at its disposal. Roos directly links the dramatic expansion of white public sector employment during the 1950s to Afrikaner elites' fears of the risk which poor, disabled or delinquent whites posed to the ideological and racial purity of the volk. The material upliftment of lower-class whites was driven not by the elite's altruism but by nationalist fervour born of racial fear and by distrust and disdain resulting from class prejudice. ${ }^{50}$ Demonstrating one of the many contradictions inherent in the apartheid project, efforts to absorb large numbers of relatively unskilled whites into the public service led to uneconomic forms of employment which clashed with reigning ideas about scientific management and workplace efficiency. Politically and ideologically, too, the process was hardly watertight. Afrikaner elites apparently had little faith in their more humble brethren's ability to provide the productive and ideological labour their project required off their own accord. Thus white civil servants were routinely subjected to often invasive and intimate forms of regulation and surveillance. The accommodation of lower-class whites into the apartheid state was clearly viewed as a necessary, if uncomfortable, requirement if white minority rule was to survive.

A number of chapters reveal the manner in which European settlers were perceived by the colonial state and by more established settlers as either wavering in or even failing to be white. While this related to familiar colonial taboos of, for instance, fraternising with Africans or engaging in politics which challenged the racial status quo, it also extended beyond intentional behaviour - that 
is, beyond those who, as it were, did not behave white. Recently settled Europeans in particular - those whose racial status might have been expected to be most secure, having so recently arrived from Europe - could fall into racial ambiguity by virtue of circumstances beyond their control. The lack of agency inherent in such shifts highlights the manner in which dominant definitions of what constituted acceptable whiteness was inherently fluent and historically contingent. George Bishi shows how, in mid-century Southern Rhodesia, amid a massive state-led immigration campaign, this perceived failure was indexed by the notion of "undesirability". The appearance of this term in contemporary sources may come as a surprise to historians of this region with its characteristic racial demography: surely, within the context of white minority rule, the force of numbers would dictate that no white could ever have been undesirable? Yet different colonies upheld different entry requirements depending on the kind of settler they sought to attract, even within the same empire. Requirements for prospective white settlers in Kenya were, for instance, more stringent than British colonies in Southern Africa. ${ }^{51}$ Bishi's case study demonstrates that both standards of morality - ranging from respectability to outright criminality - as well as economic position shaped assessments of a person's commitment to "colonial virtues" and hence their desirability within the settler community. Bishi notes several individual instances in which white settlers - all men - were deported on account of engaging in socially or morally unacceptable practices, including homosexuality, laziness, insubordination in the workplace, and parental neglect.

In the Portuguese colonies of Angola and Mozambique, too, Simões de Araújo shows how, in the 1950s and 1960s, "class inequality within white settler society informed understandings of race relations and was crucial in defining what counted as proper, civilized, or racist behaviour'. In this context, ethnicity played little role in defining ways of being white - new settlers were, after all, themselves Portuguese citizens, transplanted from the metropole to the colonial territories in an effort to bolster the colonial project amid advancing decolonisation on the continent. In this context, official discourses formulated in the metropole sought to reconceptualise the Portuguese empire as consciously, proudly and harmoniously racially integrated. The Salazar regime, with its priorities of rural colonial development, regarded Portuguese peasants as the most suited agents of this "civilising" mission. Indeed, Simões de Araújo and Castelo both show how white settlers were regarded as agents of progress, harbingers of European civilisation and conservative Catholic virtue who would bring about economic development of the colonies.

But such efforts to obfuscate race by reformulating the Portuguese colonial project as a 'Luso-tropical civilisation' nevertheless saw culture or civilisation understood in racial terms. This was vividly demonstrated in the newly established peasant colonatos, where established settlers and colonial officials soon objected to the manner in which the ignorance and poverty of the new immigrants threatened to disrupt the colony's established racial hierarchy. Continuing 
the discourse of "civilisation", but with seeming disregard for that of "multiculturalism", they argued that it was whites' vocation to simultaneously instruct and rule over Africans, who should themselves pursue civilisation, but remain respectful and obedient. In the context of such discourses, "civilisation" and engaging in behaviour and practices deemed "civilising" in nature, became the way to be white, and peasant immigrants' poverty and lack of education saw them fail to live up to this vocation. It emerges that both in the Portuguese and British colonial contexts, rural life and agricultural activity was regarded as particularly suited to or even rehabilitative for struggling whites. In Southern Rhodesia, rehabilitation schemes aimed to turn recalcitrant white youths into productive farmers. It was the failures on the part of some white settlers to live up to their vocation as bearers of superior civilisation which evoked state efforts to supervise, discipline and rehabilitate problematic whites. As the various instances of subaltern white indocility discussed in this section demonstrate, such efforts, too, often failed.

\section{The opportunities and limitations of physical and social mobility for nonhegemonic whites}

Physical mobility has been a key focus of work about whites in earlier periods, ${ }^{52}$ and a number of contributions in this book demonstrate that it remained a central feature of many white working-class lives and communities throughout the century, even in colonies generally regarded as established settler states. Hyslop's chapter demonstrates this reality in three colourful and remarkable vignettes which follow the lives of individual working-class or poor white figures across the region. The physical mobility visible in these border-crossing lives is mirrored in a number of the subsequent chapters and runs against much of the accepted wisdom in existing literature. Global mobility was a crucial formative factor in the white working-class identities of miners in Northern Rhodesia. As Duncan Money shows, white mineworkers stayed on the Copperbelt for an average of less than six years before moving on to other workplaces in the imperial network. Effectively labour migrants, they were by definition transient and transitory. This shaped the very nature of white working-class mobilisation on the Copperbelt, and Money shows how in the context of the rising tide of African independence struggles, these white workers showed little interest in propping up the white-run state in which they lived. To be sure, Copperbelt miners were no less racist than their counterparts to the south - but in contrast to the South African labour movement, their trade unions had remained largely autonomous from the state, and, as highly mobile workers, they were to a great degree detached from local political and citizenship arrangements. Copperbelt miners' white privilege was mainly determined by their relationship with management and resulting workplace arrangements. This resulted in a particular way of being white. Hence, during the 1963 strike, white workers emphasised their position as workers rather than whites, and 
unperturbed by the challenge of black nationalist demands, even appealed to African labour and politicians. Yet they remained a racially delineated class, committed to white supremacy in the workplace, if not in the political sphere.

Mobility was also a necessary feature of the job and identity of the railway workers discussed by Nicola Ginsburgh. Ginsburgh contends that the fractures and divisions created by the arrival of working-class immigrants during this period remains a blind spot in the existing literature. As hers and a number of other chapters demonstrate, European immigration to settler colonies did not unproblematically strengthen the hand of the racial state. In labour terms, states struggled with the high attrition rates of immigrant European workers. Insufficiently committed to the colony and unsatisfied with what it had to offer, many workers resigned or simply absconded. Employers bemoaned the "wandering" tendency of white workers. And Ginsburgh shows that the physical mobility of its white labour force could pose further problems to the racial state. Unaccustomed to the racialised practices of the colonies, new arrivals were routinely ignorant of or resistant to the racialised behaviours they were expected to perform. Those who did not fall into line threatened to attract the ire of the state, trade union officials or fellow white workers. This could lead to cases of such whites being deported. Physical mobility and returning to Europe was, therefore, not always a matter of choice. Bishi's chapter similarly shows that whites deemed "undesirable" by the colonial state ran the risk of being expelled, returning them to the often dire prospects they faced in their home countries.

Indeed, the socialisation of newly arrived white settlers was clearly a central concern for established white communities and racial states alike. Contemporary observers in Rhodesia stressed the role of "old hands" in explaining the acceptable boundaries of behaviour to new settlers and enforcing those boundaries through social ostracism rather than state intervention. ${ }^{53}$ Labour disputes such as the 1954 firemen's strike on the Rhodesia railways provide a helpful window onto the challenges the transient European workforce posed to the settler state in terms of their unfamiliarity with or potential hostility towards the racialised behaviours and practices of colonial life. Ginsburgh argues that the existing literature's concentration on either rural or middle-class whites results in an overstatement of the degree of social cohesion and successful socialisation which characterised white society. A focus on the urban working class offers new insights. It reveals the contradictions inherent in the settler project - the colonial state's dependence on white working-class immigrants to maintain racial labour hierarchies and ameliorate skills deficits, when these very immigrants held the potential of importing radical ideologies and nonracialist sympathies into settler society. Arguably, scholars have been too quick to assume that immigrant workers rushed to embrace the wages of whiteness offered by the racial state. The acceleration of white immigration to the Central African Federation witnessed in the 1950s should therefore not unproblematically be assumed to have served the goal of strengthening white hegemony in the region. ${ }^{54}$ 
White dominance in political, economic and social terms was an interimperial concern, closely connected to prevailing conditions in Europe and colonial empires at large. It is therefore unsurprising that immigration featured as a central concern, despite the fact that the states under consideration here at times harboured very different understandings of themselves. As Simões de Araújo shows, the mid-century context of decolonisation saw the Portuguese empire under Salazar reconceptualise itself as an ostensibly multiracial unitary state variously consisting of European and overseas territories. This constitutional and semantic effort at unifying the metropole and its colonial provinces came in the face of the rapid collapse of British and French imperial power. Simões de Araújo and Castelo's chapters demonstrate the Portuguese state's concern with promoting immigration to Mozambique and Angola in the context of advancing African independence. Indeed, Simões de Araújo identifies an 'explosion of efforts and debates' on emigration from Portugal to its colonies, to the extent that by the late 1950s, the Portuguese National Assembly viewed this as 'the fundamental question' dominating all other issues. The same period saw Southern Rhodesia, too, launch an immigration campaign in a bid to increase its white population and address skills shortages. Opportunities for physical mobility offered by transnational industrial and imperial connections were, therefore, not just pursued as an individual life choice. It was also actively promoted and driven by imperial states for whom white immigration formed a key part of strategies for political consolidation and economic development, both overseas and in the post-war metropole, and hence involved substantial public investment.

Physical mobility, crucially, created opportunities for social mobility and was often entered into for precisely this reason. As in the case of Portuguese Africa, many of the skilled workers who travelled to the Rhodesias were attracted by the upward social mobility which colonial employment promised, and which was embodied by prominent figures like railway fireman-turned-prime minister Roy Welensky. But material and social ascendance was neither universal nor automatic. Colonial newspapers reproached new arrivals for having too high expectations. Ginsburgh demonstrates the hardship suffered by many immigrant workers, with many in employment becoming reliant on relief funds evidence that the colonial government recognised that some workers were struggling to maintain a European standard of living. When the railway worker Charles Taylor was deported, he lost no time informing the British workingclass public of the fallacy of social mobility in the colonies. In addition to insufficient pay, strikers complained of inadequate public services, housing shortages, and the disdain which they were treated by other classes of whites. Clearly, racial identity was not enough to ensure upwards social mobility or social cohesion in the racial state.

Like "undesirable" whites being deported back to their European homelands, social mobility, too, could potentially be reversed. Van Zyl-Hermann's chapter reveals the anxiety which labour reforms evoked amongst white workers in South Africa at a time when assertive African labour movements and economic 
recession already posed threats to blue-collar whites' status and material position. Hyslop's three vignettes, too, demonstrate that white workers' upwards social mobility and the so-called "solving" of white poverty in South Africa was never as solid as scholars tend to assume.

This book demonstrates that an integrated history of white societies in Southern Africa is possible, and becomes particularly clear when the historian's focus is broadened to include issues of class alongside race. In contrast to prevailing understandings which cast the period of white minority rule in terms of a racialised binary power structure, the chapters presented here render visible the fact that racial identity was never the sole marker of social status and power in the region. In context of the racial state, individuals, communities and classes identified as workers and were conversely identified as poor, "undesirable" and deviant. For this hyper-visible, numerically small and - for most of the century - politically dominant group, class disrupted as much as race bound together in twentieth-century Southern Africa.

\section{Notes}

1 For the conceptual confusion around the term "white working class", see Bhambra, 'Brexit, Trump, and "Methodological Whiteness"'; Roediger, "Who's Afraid of the White Working Class?'

2 Stoler, 'Rethinking Colonial Categories', 137-138.

3 Roos, 'South African History and Subaltern Historiography'.

4 Arnesen, 'Whiteness and the Historian's Imagination'.

5 See Posel, 'Whiteness and Power'; Roos, Ordinary Springboks; Grundlingh, “"Are We Afrikaners Getting Too Rich?"';Van Zyl-Hermann, 'White Workers and South Africa's Democratic Transition'; D. Money, “No Matter How Much or How Little They've Got, They Can't Settle Down"'. One important exception here, though he discusses a slightly earlier period, is Van der Walt, 'The First Globalisation and Transnational Labour Activism in Southern Africa'.

6 One exception to this, which demonstrates the value of a regional approach, is Adhikari's edited collection Burdened by Race.

7 Roediger, The Wages of Whiteness, 8.

8 Michelle Brattain, for instance, argues that 'Whiteness was, and continues to be, a very real determinant of social relationships and material benefits.' Brattain, Politics of Whiteness, 4.

9 Van Zyl-Hermann and Boersema, 'Introduction'; Steyn, 'As the Postcolonial Moment Deepens'.

10 Posel, 'Race as Common Sense'.

11 Bozzoli, 'Intellectuals, Audiences and Histories'; Bonner, 'New Nation, New History'; Freund, 'Labour Studies and Labour History'.

12 Katz, A Trade Union Aristocracy; 'Part Five: White Workers and Political Ideology' in Bozzoli, Class, Community and Conflict; Katz, The White Death;Vincent, 'Bread and Honour'; van Onselen, New Babylon, New Nineveh, 309-326; Lange, White, Poor and Angry; Hyslop, The Notorious Syndicalist; Krikler, White Rising; Higginson, 'Privileging the Machines'; Van der Walt, 'Anarchism and Syndicalism in South Africa'.

13 Freund, 'Introduction', xiii.

14 For instance, the contributions in Morrell's edited collection White but Poor all focus on this period.

15 Teppo, 'The Making of a Good White'; Grundlingh, 'Are We Afrikaners Getting Too Rich?'; Hyslop, 'The White Poor'; Jackson, 'Shame of Not Belonging'; Posel, 'Whiteness 
and Power in the South African Civil Service'; Mooney, 'Ducktails, Flick-knives and Pugnacity'.

16 Freund, 'A Ghost from the Past'.

17 Kruger, '(Dis)empowered Whiteness'; Sibanda, 'Social Pain and Social Death'; Sibanda, 'Wounded Citizenship'; Schuermans andVisser, 'On Poor Whites in Post-Apartheid Cities'; Sharp and Van Wyk, 'Beyond the Market'; Bottomley, Poor White. In terms of media coverage, see for instance 'The Editors: Do White People Have a Future in South Africa?' BBC News, first broadcast 27 May 2013; 'Reggie Yates Extreme South Africa:The White Slums', BBC Three, first broadcast 20 February 2014; 'Trevor MacDonald: White Poverty After Apartheid', ITV, first broadcast 21 June 2018.

18 Yudelman, The Emergence of Modern South Africa, 235; Phimister and Van Onselen, 'The Labour Movement in Zimbabwe', 44-45.

19 Penvenne, 'Labor Struggles at the Port of Lourenço Marques', 230.

20 Perrings, Black Mineworkers in Central Africa, 51-54.

21 Phimister and Tembo, 'A Zambian Town in Colonial Zimbabwe', 53. On the ostensible retreat and delegitimisation of class identities in favour of racial identification in the South African context, see Kenny, 'Servicing Modernity', 374, 377; Van der Westhuizen, White Power, 10-11; O'Meara, Forty Lost Years, 78.

22 Drew, Discordant Comrades, 67-73.

23 Van Zyl-Hermann, 'Baas or Klaas?', 142-143.

24 Van der Linden, 'Labour History'.

25 Davies, 'The White Working-Class in South Africa', 49; Wolpe, 'The "White Working Class" in South Africa', 223-230; Davies, Capital, State and White Labour, 25. For the contrary view on white workers in the gold industry, see Johnstone, Class, Race and Gold, $25,56-61$.

26 Scholars on Angola made a similar argument, that class differences among the white population were blurred and subsumed by race. Clarence-Smith, 'Class Structure and Class Struggles', 113-115.

27 Morrell, White but Poor, xi-xii. The chapters on Southern Rhodesia are Challis, 'Education and Southern Rhodesia's Poor Whites'; Stigger, 'Minute Substance Versus Substantial Fear'.

28 See Phimister, 'White Miners in Historical Perspective'; Lunn, Capital and Labour on the Rhodesian Railway System, 77-106; Money, “"There Are Worse Places Than Dalmuir!””

29 Nyamnjoh, 'Blinded by Sight', 70.

30 Fisher, Pioneers, Settlers, Aliens, Exiles; Hughes, Whiteness in Zimbabwe; Pilossof, The Unbearable Whiteness of Being; Law, "'Mostly We Are White and Alone"”; Alexander, 'Orphans of the Empire'.

31 Pilossof and Boersma, 'Not All Whites Are Farmers'.

32 Hartnack, 'Whiteness and Shades of Grey'.

33 Brownell, The Collapse of Rhodesia, 3; Bender and Yoder, 'Whites in Angola on the Eve of Independence'; Penvenne, 'Settling Against the Tide', 86.

34 Department of Statistics, Statistical News Release: Mid-Year Estimates - Republic of South Africa (24 October 1974) (Pretoria: Department of Statistics, 1974).

35 Hodder-Williams, 'Afrikaners in Rhodesia'; Stassen, Afrikaners in Angola.

36 Mlambo, A History of Zimbabwe, 79-83.

37 Glaser, 'Portuguese Immigrant History'.

38 Brownell, 'The Hole in Rhodesia's Bucket'.

39 Johnstone, 'White Prosperity and White Supremacy', 135.

40 Steyn, 'Rehabilitating a Whiteness Disgraced', 143; Guillaume and Teppo, 'Le Privatisation Du Destin'.

41 Glaser, 'White but Illegal'; Chichava, 'Unlike the Other Whites?'; Brownell, Collapse of Rhodesia, 14.

42 Jackson, 'Shame of Not Belonging', 86. 
43 There is emerging scholarship on this in Zimbabwe, see Kufakurinani, Elasticity in Domesticity, 73-105; Mhike, 'Intersections of Sexual Delinquency and Sub-normality'.

44 Koorts, “"The Black Peril Would Not Exist If It Were Not for a White Peril”'; Bundy, Poverty in South Africa, 40-53, Seekings, "'Not a Single White Person Should Be Allowed to Go Under"'; Kufakurinani, 'Empire and Sexual Deviance'.

45 Shutt, Manners Make a Nation.

46 Lucas Phillips, The Vision Splendid, 177.

47 St. John Wood, Northern Rhodesia, 63.

48 Perhaps the best example of this is Dimitri Tsafendas, a Mozambican-born revolutionary who assassinated Hendrik Verwoerd, and had attempted to have himself reclassified from 'white' to 'coloured' under apartheid laws, see Dousemetzis and Gerry, The Man Who Killed Apartheid. The Polish journalist Ryszard Kapuścińki also encountered white guerrillas in the ranks of the Movimento Popular de Libertação de Angola while reporting on the collapse of Portuguese rule in Angola: Kapuścińki, Another Day of Life, 54, 67, 78.

49 Posel, 'The Apartheid Project, 1948-1970'.

50 In an earlier article, Deborah Posel has similarly pointed to the stigmatisation of white civil servants. See Posel, 'Whiteness and Power'.

51 Kennedy, Islands of White, 43.

52 Jonathan Hyslop has produced a large and diverse body of scholarship in this area. See for instance Hyslop, 'The Imperial Working Class Makes Itself "White"'; Hyslop, The Notorious Syndicalist; Hyslop, 'The World Voyage of James Keir Hardie'; Hyslop, 'Scottish Labour, Race, and Southern African Empire'; Hyslop, "'Undesirable Inhabitant of the Union"'; Hyslop, 'The Politics of Disembarkation'.

53 Lessing, Going Home, 202-203; Kennedy, Islands of White, 179-180.

54 This can usefully be linked to debates on whiteness in North America on whether whites from poorer regions of Europe - Italians, Greeks or Slavs - became white in their new society, or whether they were 'white on arrival'. See Barrett and Roediger, 'Inbetween Peoples'; Guglielmo, White on Arrival. 


\title{
1 Workers called white and classes called poor
}

\author{
The "White Working Class" and \\ "Poor Whites" in Southern Africa, \\ 1910-1994
}

Jonathan Hyslop

\section{Introduction}

By 1910, the countries of Southern Africa represented more than just geographical contiguity; they were coalescing into an economically connected region. In that year, the line of rail from the south reached the mines of Katanga in the southern Congo, joining Elisabethville to a steam-powered transport network stretching through the Rhodesias, to the South African ports and Lourenco Marques. Yet too often the history of the unified South African state, which was being established at the same time, has been dealt with in relative isolation from the region, in a kind of South African exceptionalism. And amongst the subjects that South African historiography treats of, that of the "white working class" and "poor whites" has been particularly strongly assumed to reflect the peculiarities of the country. In superficial accounts, the notoriously confused slogan of the Rand 1922 miners' strike, 'Workers of the World, Unite and Fight for a White South Africa', is sometimes presented as a kind of emblem of the uniquely bizarre history of South African white labour. But the white labour question in South Africa was much less unique in its dynamics than is often assumed. What happened within the boundaries of the South African state was paralleled in, and connected to, a wider world. So how could the question of white workers in southern Africa look if we thought about it in a transnational, Southern African framework? Does the manner in which "subaltern" whites figured in the social order and politics of the South African racial state, between its formation in 1910 and its political democratisation in 1994, appear different if reconsidered in relation to what we know about similar groups in the other countries of the region?

There are two relatively obvious ways in which such a rethinking can proceed. The first is to take a comparative approach. There were for example some clear similarities and important differences in how political issues played out in Southern Rhodesia and in South Africa. But this method has its limitations. It tends to assume the existence of neatly separate entities which can be compared. This can lead to attributing greater coherence to what transpired within territorial boundaries than is necessarily warranted, and to ignore the way in which networks of power, and social struggles, spilled across national 
or imperial borders. In Southern Africa, with its unfenced and often thinly patrolled borderlines, and its long-lasting flows of capital and labour across imperial boundaries, it is especially misleading. Both workers and those who sought to dominate them, cooperated and competed across borders to a far greater extent than a nationally constrained imagination allows for. So it is crucial to consider, as a second approach, the connections which contemporary scholarship calls "transnational". But I also want to pursue a third axis of inquiry. Workers, capitalists and state leaders responded not just to local or regional concerns, but to the great global ideological struggles over political and economic questions and to the economic conjunctures that accompanied them. I call this dimension "contemporaneity": here one considers the way in which political actors framed what they were doing in relation to globalscale ideologies and to events to which they may or may not have had direct connections. Actors read, or creatively misread, the wider world for their own purposes. White workers and white elites often made reactionary choices - but they were not parochial. They often had an astute awareness of the global political contexts in which they operated.

This chapter then, uses the three methodological tools of comparison, the study of connections and the study of contemporaneity to reconsider the literature on the poor white and white working class in South Africa in a regional and a global context. What questions though are we attempting to answer? Three lives which cross regional boundaries provide a starting point for formulating lines of inquiry.

E.J. Brown came from Australia to the Rand before the First World War. He participated in the leadership of the great New Kleinfontein strike of white workers in 1913, which resulted in a bloody general strike in Johannesburg and short-term victories for the miners. They were crushed by the imposition of martial law in the next year. Brown moved on to the Katanga mines of the Belgian Congo. There, in 1919 to 1920 he led an extraordinarily militant strike wave of the predominantly British and South African white miners around Elisabethville, which included a dynamite attack on the office of the attorney general and the blowing up of a trestle bridge and railway engine. Deported back to South Africa, Brown last shows up in the historical record in a 1921 letter from the embryo South African Communist Party to the Comintern headquarters in Moscow, listing their leading militants. ${ }^{1}$

"Anna Prinsloo" was born in 1916 in the Afrikaner community of Humpata in Angola. These Boers lived in an only partially monetised economy, grazing their cattle and trading and bartering with the Portuguese, the Moemereya and the Ovambo. They were targeted for "saving" as "poor whites" by Afrikaner nationalist ideologues and in 1928 many, including Anna's family, were persuaded to move to South African-ruled South West Africa. Anna's father was allocated some land there, but it was inadequate to support the family. The teenage girl, who was not fully literate, was forced to seek work as a cleaner and washerwoman first in Gobabis, then in Windhoek. She had two children, possibly out of wedlock. Taking her daughter to Cape Town for medical treatment, 
she was a domestic worker for a doctor in Rondebosch, before happily moving to a much better paid job in a garment factory. Returning to South West, she eked out a living making charcoal on her father's farm. In 1945, Anna married a marginal Afrikaner farmer from Ghanzi in Bechuanaland and moved with him to the British territory. The struggling couple tried to break into small business: they set up a modest transport business and Anna borrowed money to run a café for African migrant workers. After her husband's death left her deep in debt, Anna, who had acquired a heavy-duty license, went back to the transport business. She drove her truck along the desert roads accompanied by four or five African employees, sleeping on the ground at the side of the vehicle by night. By 1973, she was planning to take out citizenship in the now independent Botswana. ${ }^{2}$

Born in 1930, Maria de Lurdes Delgado grew up in central Portugal's Beira Baixa region. She emigrated to Mozambique in 1953 to marry a local man who had gone to work as a foreman on the railways. Maria, who had not completed primary school, took this step to escape a life of manual labour in her tyrannical father's vegetable garden. Daniel however turned out to be a brutal and unfaithful husband. Maria spent fifteen miserable years in remote rail stops in the Mozambiquan interior, suffering illness, a sense of social isolation, and fear of the animals, snakes and scorpions. The couple had two children, but their daughter contracted polio. Maria took her to Johannesburg several times for treatment: there she felt humiliated by her lack of English and her struggle to pay the bills. By 1968, alarmed by the Frelimo insurgency, Maria and Daniel decided to move to South Africa. They had to evade the secret police in order to do so, as emigration was not permitted by the authoritarian Portuguese regime. In Johannesburg, Daniel found work as a welder. Maria's daughter became pregnant by a relative, and Maria took on raising the child. Then Daniel and their son were in a terrible car accident. The boy survived, but Daniel died. Only now did Maria's life change for the better. Her house was paid off by Daniel's insurance, and she also received a small but significant cash payment. She found work and learned to drive. Maria then met a Portuguese refugee from Angola, a kind man called Fernando. They married and were happy together. The couple moved to East London and opened a restaurant, which was highly successful. For the first time in her life Maria experienced a modest prosperity, and her children also did well in South Africa, establishing middle-class careers for themselves. ${ }^{3}$

The by now very considerable social history literature on South Africa has paid a great deal of attention to the questions of the histories of poor and working-class whites. But the stories of E.J. Brown, "Anna Prinsloo" and Maria Delgado are striking because they run, if not exactly in contradiction, then at tangents, to the accepted wisdom. On the one hand work on the white working class in South Africa has largely concentrated on the labour movements created by in the early decades of the Twentieth Century. This literature has explored the vicious class conflicts between white unions and the Rand mine owners and other capitalists. ${ }^{4}$ It has emphasised the racial protectionist politics 
of these unions, and has provided an understanding of how the leadership of a number of them were captured by Afrikaner nationalists in the 1940s. ${ }^{5}$ On the other hand scholarship has shown how poverty and unemployment amongst whites during the period of urbanisation in the first three decades of the century, provided the context for the political construction by white, and especially Afrikaner, intellectuals of the "poor white question". 6 The gap between the racial status and the economic position of a white underclass was seen as a threat to white dominance. Across the range of work carried out in these fields, there has tended to be a belief that these social cleavages in white South African society were ultimately overcome by the action of the South African state. The 1930s saw the mobilisation of the radical wing of Afrikaner nationalism under D.F. Malan around the poor white question. It is now widely assumed that the policies of the Apartheid government, initiated from 1948 by Malan as prime minister, eliminated white poverty and created mass-scale transformation of white workers and poor people - or at least their children - into the middle, professional and business classes. This view that the white working class ceased to be a significant social or political force in South Africa is what I would call the "thesis of incorporation". But as will be shown, this is a mischaracterisation of the changes in the class structure of South Africa, and a misreading of its political dynamics. And it is equally misleading when it is applied to the other countries of the region.

The stories of these border-crossing lives provoke different kinds of questions from those which have conventionally been posed. Should not the migration of white workers across national boundaries in the region become a more central part of our understanding of white labour questions? Does Brown's career point to a white labour movement history which need to be read regionally? Does that career also not suggest the need to give greater weight to the influence of global forms of labour political radicalism on white workers Southern Africa? At the same time Anna and Maria's lives remind us that the history of white workers cannot be conflated either with the histories of white labour organisation or of Afrikaner nationalism. Why have the histories of Portuguese workers and other continental European-origin ethnic groups not been much integrated into the stories we have told about white labour? Was the upwards mobility which many white working-class people - including Anna and Maria - certainly did experience across time actually as solid as is often assumed: or was it - as in Anna's case - in reality somewhat tenuous? And if there was a transformation in the conditions of the white poor in South Africa, is the standard narrative about the role of Afrikaner nationalism in it really justified? Anna, after all, despite being the recipient of the beneficence of an early and energetic manifestation of the politics of poor-white-saving, and despite certainly partaking in some of the racial attitudes of white Southern Africans, seems to have been impervious to the appeals of Afrikaner nationalism. Turning her back on the considerable racialised social benefits she would have enjoyed in South West or South Africa, she saw her future in a now-independent black ruled state. Just how incorporated were the white working class? 


\section{Artificial boundary-drawing and naturalised racial categories}

We need to question the tendency to naturalise the very terms "white working class" and "poor white". To be "white" was not of course to possess any particular biological attribute or national origin. To take a striking example the term "gens du couleur" (people of colour) was commonly and indeed legally used in the Belgian Congo's Elisabethville to denote the marginal Italian, Greek and Portuguese traders who catered to African customers. ${ }^{7}$ Colour could, as it were, be acquired or lost. White people were simply people who the social order called white. Who was included or excluded from such a category was a matter of extremely arbitrary historical contingency.

There were important divergences in the racial ideologies of different colonial states, which affected the way white identity was managed - and these techniques themselves varied across time. This made processes of drawing racial boundaries crucial to the way states constituted themselves. The existence of people called "white" whose standard of living was similar to or below that of colonial subjects, and the physical and cultural proximity to colonial subjects that this inherently involved, was almost universally seem by dominant groups as threatening the assumptions of superior white propensity to achievement. ${ }^{8}$ But very different strategies were pursued to "solve" this problem.

"The Poor" has historically tended to be a category imposed from outside: through it, dominant classes constitute groups of people as objects of charity, or of coercion, or as targets for projects of social reform, and in the process reinforce their own power. In Southern Africa category of "poor white" tended to be one imposed from above on working-class and lumpenproletarian people by elites, seeking both to name them as a problem for to be solved, and as a group to be mobilised around the imputed racial identity. This often - although not always - involved removing them from zones of social ambiguity in which they were living in boundary-blurring proximity to people designated as "nonwhite". The term "Poor White" seeks to displace a potential class identity with a racial identity by constituting poverty as an anomaly in racial status rather than a product of capitalist social relations.

The "white working class" on the other hand tended initially to be selfdesignated, as white workers sought to leverage prevailing racial discourses to demand particular privileges on the basis of an assumed racial identity. This selfidentification was however often manipulated by elites, who, in the interests of increasing their own political advantage, sought to move white workers to more intense forms of boundary policing. One could thus say that poor whites were workers who were told from above that their racial identity was more important than their poverty, while the white working class were workers who demanded of capital and the state that their racial status should be specially protected in the labour market (sometimes with encouragement from more privileged strata).

The different ways in which racial boundaries were drawn in different states had real effects. There is a tendency to assume that because all the states we are 
looking at here were racist - as indeed they were - the differences in the ways in which they operated can be regarded as minor. But this is an error - the differences were real and significant. Perhaps the most important example arises in the case of the Portuguese colonies after the Second World War. As the Portuguese government turned towards the new colonial policy, it adopted an ideology based in the writings of the Brazilian scholar Gilberto Freyre. His term, "Lusotropicalism" put forward a notion of the Portuguese colonial enterprise as based in a supposed natural genius of the nation for racial boundary-crossing. This was a blatant attempt to sell the Portuguese Empire to a world in which narratives of racial superiority were under attack. And it has consequently been rightly debunked by many scholars, who have correctly pointed out the racist nature of the imperial project. ${ }^{9}$ Yet this debunking can lead to a neglect of the ways in which Portuguese policies were actually at variance with those of South Africa or Southern Rhodesia. Boundaries were more porous in the Portuguese colonies and that created a set of different dynamics in the social situation of the white poor and working class. Schools and working-class residential areas were not rigidly segregated, whereas in the South Africa and Rhodesia of the time they were. All countries in the region were racially structured societies, but their racial structures worked in significantly different ways.

Nor were "whites" a solid bloc of equal status. There were also aspects of intra-white ethnic or status distinction which cut across the logic of a primary racial identification, such as the very intense Anglophone - Afrikaner divisions in the British empire countries. The Portuguese attempt to create a colonial community was bedevilled by the self-inflicted wound of a difference in status between the Portuguese-born, referred to as "first class whites", and the colonial-born descendants of settlers, known as "second class whites". ${ }^{10}$ The latter were not eligible for significant positions in the colonial administration and had no automatic right to travel to Portugal. Although the legal distinction was set aside late in 1950, it was embedded in settler culture as a status distinction right to the end of Portuguese rule. ${ }^{11}$ Moreover, in South Africa and the Rhodesias, anti-Semitism and intense hostility to Portuguese, Greeks and other white minorities, often underpinned by racist ideologies, were quite common.

\section{The persistence of class}

The persistence of class amongst Southern African whites, and its continuing political effects are important to recognise. The South African white occupational structure remained strikingly pyramidal right to the end of apartheid. And intra-white class differentiation was even more strikingly the case in the Portuguese colonies, especially Angola, where there was a very substantial marginalised white underclass throughout the colonial period. Class divisions amongst whites continued to affect politics to the end of the racial states, in ways which cannot be understood purely by focusing on the racial politics side of the equation. This is not in any way to diminish the centrality of the racial systems, and the extent of the social advantages they gave to those identified 
as white. But it is to say that we cannot assume class differentiation amongst whites declined into relative social and political insignificance. The thesis of incorporation is far from valid either for South Africa, or for other countries in the region.

Certainly there was at particular times, large scale white upwards social mobility or improvement in living standards. In South Africa, the white working class experienced remarkable levels of wage increases between the 1940s and the early 1970s. In that country, there was also a growth of the white middle class, in a halting and uneven way from the interwar years, and spectacularly in the 1940s to 1970s. In Southern Rhodesia there was also widespread growth in white affluence in the post-Second World War years. Portuguese colonists improved their economic and educational position in the same period compared to the population in the home country (although not to the same extent as white South Africans or people in the richer west European countries). ${ }^{12}$ However, it is important not to fall for the idea of a universal prosperity or the disappearance of class. Moreover, there was a clear economic decline of the working class in the region from the 1970s. The economic security of the white working class in Rhodesia faltered in the last decade of white rule. In South Africa, by the 1980 s, with a turn to free marketisation, very visible white poverty had reappeared.

It is important to note though for all the relative prosperity and upwards social mobility of the 1940s to the 1970s, neither South African nor the Portuguese colonial whites were predominantly middle class. In South Africa most white employees remained in working-class positions. In the mid-1960s whites occupied the vast majority of artisan and apprentice positions, three quarters of all routine white collar jobs and nearly half of the mostly low-skilled security jobs, as well as constituting significant minorities of semi-skilled operatives and low level service workers. Only at the lowest level of unskilled jobs, were whites more or less absent. ${ }^{13}$ In the Portuguese colonies class differentials were even more striking. In the Angolan cities of the 1950s there was a clear elite layer, living in almost exclusively white suburbs. But below that was a very modest middle stratum of artisans, clerks, minor civil servants, poor farmers and skilled transport workers. In stark contrast to the rigid social segregation prevailing in the South Africa and Rhodesia of the time, this group were somewhat socially integrated with the displaced descendants of the old, mixed-race and black trading elite and the assimilados (Africans granted Portuguese citizen status). The poorest whites - unskilled workers, struggling craftsmen, taxi drivers and the indigent, lived in the slums of Luanda, Lobito and other towns amongst black and mixed-race neighbours. ${ }^{14}$ In Mozambique during the 1970s, there is evidence of significant class distinction in white society; for example, in urban schools, white working-class pupils experienced a strong sense of social discrimination, and unlike the white elite often had social links with black pupils. ${ }^{15}$

Even at the end of apartheid, it is important to note how large the section of South African whites who had not risen into the middle classes remained. Notwithstanding changes in production processes towards techniques such as 
modularised concrete building, which did not require traditional artisan skills, white numbers in the artisan trades and apprenticeships remained steady. There were over half a million white clerical employees, with women occupying a significantly increasing proportion of the workforce. There were still large numbers of white semi-skilled operatives and the numbers of white security employees had actually grown. ${ }^{16}$

\section{Working-class access to political power}

Varying forms of white working-class access to political power and the different levels of organization that allowed, was crucial to the political shaping of these societies. Participation in formal political systems and meaningful unions was central in white workers' ability to shape politics, and the degree of power they exercised had real effects. This is demonstrated in a negative way by the direction of events in the Portuguese colonies. With the imposition of a dictatorship in metropolitan Portugal in 1926, which was to last for another nearly five decades, Portuguese-origin workers in the colonies lost the democratic rights that they had enjoyed and exercised during the liberal republic founded in 1910. In Lourenco Marques the substantial wage and benefit structure built up over previous decades by the port and railway workers was demolished. ${ }^{17}$ In 1930-1 serious political disturbances in Angola by political deportees, provincial autonomists and soldiers was crushed by the army, and troublesome white working-class radicals were repatriated to Portugal in significant numbers. ${ }^{18}$ While it is possible to debate whether Antonio Salazar's Estado Novo (New State), founded in 1934, was exactly fascist, it certainly belonged to the family of European authoritarian governments of the interwar years, and it outlasted all of them except Franco's Spain. ${ }^{19}$ Although political activity was not entirely suppressed, white workers lacked any form of meaningful unionisation or political representation. Bogus sindicatos substituted for labour organisation and local government was subordinated to the central state. Not only did this repression prevent workers from shaping the politics of the colonial era, but it also meant that they lacked the political resources to impose their demands in the moment of the collapse of the empire in 1974-5. In September 1974 a hopelessly bungled settler coup in Mozambique against the Portuguese revolutionary government's political handover to Frelimo, crumbled rapidly. It precipitated a mass flight of whites to South Africa. ${ }^{20}$

Somewhat similarly, in the Congo, during the early 1920s, mine management replaced white South African and British workers with Belgians, especially economically vulnerable miners from the depressed Hainaut region. On short-term contracts and cowed by the prospect of unemployment at home, they remained quiescent throughout the inter-war years. Elizabethville became a conservative Catholic-dominated enclave. ${ }^{21}$ There was some brief labour insurgency by Belgian workers at the start of the 1940s, precipitated by the special conditions of wartime, but by and large they had little opportunity to express themselves politically throughout the rest of the colonial period. 
By contrast, white workers in South Africa and Southern Rhodesia, having attained effective participation in the parliamentary system from 1910 and 1923 respectively, were at times able to use it quite effectively to advance their perceived interests. The South African Labour Party (SALP), a trade union based party rooted in the British immigrant working class was able to conclude an alliance with General Hertzog's National Party to form a "Pact" government in 1924. The SALP's influence on the policies of the Hertzog cabinet resulted in pro-white labour legislation that formed the template for the policies that were to prevail for over five decades. The creation of a parastatal electricity provider and iron and steel company was carried out with a special mission to provide jobs for working-class whites. The favouring of white workers on the state owned railway system drove out workers of colour from unskilled jobs on a huge scale. The "rate for the job" protecting white artisans against African labour competition was institutionalised. Wage boards were empowered to uphold minimum wages, and this was used to push employers to hire more white labour, creating a considerable influx of white Afrikaner women into industrial work in this period. Most importantly of all, the Hertzogites implemented an extensive system of white pensions, disability grants and welfare payments. This general approach was maintained and actually extended by the coalition of Hertzog with Smuts from 1933. The 1934 Slums Act created the basis for extensive social housing construction for whites. And when a now more socio-economically pragmatic Smuts took over in 1939 he continued in the same direction. ${ }^{22}$ The idea that the post-1948 Nationalist government "saved" the white working class is greatly exaggerated and owes a lot to its own propaganda. After 1948, Malan and his successors merely continued established social policies, with a somewhat higher level of spending and a greater emphasis on Afrikaner ethnic interests.

The Rhodesias represent an intermediate case, with an initial very hostile environment for the white working class later shifting to a more hospitable one - although never quite as favourable as in the South African case. In the 1920s and 1930s, Southern Rhodesia was a particular bastion of rigidly free market politics. In these years white workers there suffered repeated wage cuts and retrenchments. State health care, pensions, housing and welfare services were almost entirely lacking. Management and government took a tough stance towards labour organisations, in the context of a generally depressed economy. ${ }^{23}$ Unsuccessful white farmers also suffered economic devastation as commodity prices declined: experiences of absolute white rural indigence are recounted by Daphne Anderson in her autobiographical novel The Toerags. ${ }^{24}$ In response, the Rhodesian Labour Party became strong, capturing about a third of the seats in the legislature by 1939. The Second World War marked an important break, with Huggins absorbing some Labour leaders into his government and turning towards a more economically interventionist state.

Roy Welensky was able to use his position as an originally labour-based leader of the whites in Northern Rhodesia during the 1940s, to leverage a massive political transformation of the region. The son of a ne'er-do-well Jewish father 
and an Afrikaner waitress mother, and famously, in his own description " $100 \%$ British", Welensky had grown up on the literal wrong side of the tracks in his parents' seedy boarding house on Salisbury's Pioneer Avenue. As a teenager he trained as engine driver and became a boxing champion. He was an activist in the railway union, where he became steeped in the classical literature of the British socialism. After being transferred to Broken Hill in Northern Rhodesia as a punishment for his union militancy, he applied his considerable political talents to become leader of the labour group in the legislature and from there was able to become dominant figure in Northern Rhodesia settler politics. It was from his base in the labour movement, and success in the legislature that Roy Welensky launched his bid for a Central African Federation. ${ }^{25}$ Welensky's project was perhaps the most ambitious to emerge from the world of white labourism in the modern history of Southern Africa. His aim was, through the Federation, to unite the settler political power of Southern Rhodesia with the now fabulous copper-mining based wealth of Northern Rhodesia. ${ }^{26}$ It was the growing presence of Afrikaner workers in the Rhodesias that seems to have been crucial to the British government's ultimate accession to the Federation. Particularly after Malan's "Purified" Nationalists took power in 1948, the fear of both British Conservatives and British Labour was that rejection of the settlers' demands would drive the Rhodesian whites into the hands of the South Africans, creating a huge and aggressive white geopolitical bloc that would come into conflict with future independent African states, and impose South African - style policies internally. The misguided British conclusion that the Federal structure would allow Westminster to moderate racial policy, gradually create greater African representation and resist South African influence, provided Welensky with the gap in which he could pursue his policy. ${ }^{27}$

\section{Regional working classes and global politics}

White working-class political organisations need to be understood not just as local phenomena but as possessing specific links across the region, and into the outside world, which had important local effects. Before the First World War, there was a global British labour network, connecting the settler colonies and the empire, and it articulated an ideology of white labourism, in which colonised workers were seen as a "cheap labour" threat to white workers. This programme for protecting the position of white workers was crucial to the political development of South Africa and Australia especially, but was also largely accepted in Britain itself. ${ }^{28}$

In Southern Africa the period from 1910 to 1923 was one of harsh confrontation between, on the one hand, politically powerful capital and weak but violent states, and on the other militant white workers, most of whom supported racial protectionism. The great strikes of white workers on the Witwatersrand in 1913 and 1914 and the insurrectionary Rand general strike of 1922 were the high points of this movement. The South African Labour Party became a powerful embodiment of this politics. Because of the multiple connections 
of British immigrant and white South African activists to other countries in the region, this militant mood spread. On the Rhodesian railways and mines, there were large scale strikes in 1919 and 1920. A Rhodesian Labour Party emerged with an anti-big business message. ${ }^{29}$ And as we have seen, the period also saw militant action by British and South African workers on the mines of Katanga. White Labourism never again returned to this level of mobilisation, but it continued to be a transnational force in the region. Their mobilisation of British and South African workers on the Northern Rhodesia mines in 1940, for example, laid the basis for the highly favourable post-war employment conditions which they attained. ${ }^{30}$

But white labourism was not the only global trend to influence white labour in the region. There are four other important international networks that are notable in Southern Africa. The first is that of the syndicalism of the period of roughly 1910 to 1923 . Small numbers of Syndicalists, with their brand of revolutionary trade unionism, emerging out of the British and Australasian movements of the early twentieth century were often in those years able to seize the leadership of significant numbers of workers, even though unionists were usually more conservative or white labourist than they. The Syndicalists' effective organisational tactics - although not their relatively advanced views of racial politics - attracted broad support at moments of crisis. A number of key individuals in the Rhodesias had been exposed to international syndicalist militancy in Britain or South Africa in the pre-war years. For instance, Jack Keller, the leader of the Rhodesian railwaymen and founder of the Rhodesian Labour Party had participated in the 1911 British railway strike. ${ }^{31}$ Union militancy fed into a wave of white populism, as white workers played a prominent part in defeating a proposed unification with South Africa in the 1922 referendum, with activists viewing the Smuts governments repression of the Rand miners' strike as a manifestation of the fate that awaited Rhodesian workers.

There was also a strain of syndicalism in the Portuguese colonies, but on a more minor scale and inhabiting a different, Iberian cultural world. Syndicalist activism and industrial action was particularly strong amongst the railway workers of Angola (especially Lobito) and in the port and railway system of Lourenco Marques. ${ }^{32}$ The role of syndicalists - many of them after 1917 sympathetic to the Russian Revolution - and the intensity of the labour struggles up to 1923 , is crucial to understanding the intensity of upper class fear of the potential for white workers to be drawn into potentially dangerous political paths, across a very long subsequent period.

Secondly, partially but not entirely overlapping with white labourism, the mainstream of British social democratic politics and trade unionism had considerable links to labour groupings and unions in Southern Africa into the 1950s. Gradualist projects of social reform and Fabian attempts to moderate the harshness of the racial politics of empire had some impact in these circles. In the early 1940s, both South African and Rhodesian Labour Parties reflected the contemporary social policy radicalisation of the British Labour Party and 
the shift in the progressive British intelligentsia towards a more critical view of "scientific" racism. The SALP Mayoress of Johannesburg, Jessie McPherson, and the labour-connected mayoress of Salisbury (Harare), Gladys Maasdorp, for instance, were leaders who sought to move their organisations away from racist policies and towards a full social democratic programme. ${ }^{33}$

Thirdly, there were international communist networks, which though thinly represented in the white labour movement, attained positions of considerable influence on white workers at particular moments. Particularly remarkable was the success of the communist led servicemen's organisation, the Springbok Legion, in winning support amongst white South African troops in the North Africa in 1941-3. ${ }^{34}$ The figure of Frank Maybank stands at the confluence of white labourist, social democratic and communist political strands: a British-born Australian Communist who led the crucially important, racially protectionist 1940 white miners' strike in Northern Rhodesia, and who very successfully mobilised the leadership of the British Labour Party and trade unions to defend him. ${ }^{35}$ There was also a small scale level of underground activism of the Portuguese Communist Party in the Colonies. There was clandestine Portuguese communist labour activism in Angola and amongst white dockworkers in Lourenco Marques, which played a role in strikes there in the 1940s and 1950s. Dissent also surfaced in the form of the particular popularity in Angola and Mozambique of the leftist General Humberto Delgado, whose opposition shook the regime, first from within, and later from exile, before his assassination in $1965 .^{36}$

Fourthly, on the other side of the spectrum, the influence of international right-wing anti-communist trade unionism - strong especially in US, Australian and to a lesser extent British unionism in the late 1940s and 1950s - has perhaps been underestimated. Anti-Communism had a palpable effect on white trade unionists in the Rhodesias and South Africa between the 1940s and 1960s. Within the Afrikaner nationalists drive to take over the South African unions, Anti-communism was an ideological commitment of its own, and not just a cover for nationalism and racism. There was a genuine sense of fear that white workers were succumbing to the left-wing ideas of some of their union leaders. Senator Jan De Klerk characterised the campaign as an attempt to 'stem this wild flood of Communism'. ${ }^{37}$ Roy Welensky forms an interesting bridge, through anti-Communism, between the Southern African white labour tradition of the first half of the twentieth century and the rise of the international far right in the second half. By the early 1960s, Welensky attracted a significant section of British Conservative parliamentarians for his last-ditch attempt to save the Central African Federation: they included the young Margaret Thatcher. ${ }^{38}$ In Southern Rhodesia, in the late 1950s, white workers, reacting against the relatively liberal and paternalist racial policies of Prime Minister Garfield Todd, swung behind the populist racial protectionism. They ended up in the fold of Ian Smith's Rhodesian Front, which was saturated with "anti-communist"ideology and became closely aligned with the British and American extreme right. Anti-Communism has often been assumed to have been simply a cover 
for racial ideology in the region, but it was also a force with a life and political dynamics of its own. ${ }^{39}$

\section{The ambiguities of immigration}

Fear of the white working class and the creation of a poor white stratum was a major brake on the immigration of Europeans to the region throughout this historical period. One would perhaps assume on logical grounds that the authorities of racially constituted states where the politically dominant group was a minority, would have wanted to boost their numbers. Yet for much of the period, elites held back because they saw incomers as potentially disruptive elements, political radicals, or as disturbers of racial boundaries. The view was put in extreme form in the early 1930s by Belgian Congo Governor Pierre Ryckmans, who opined that "the "poor whites", blancs pauvres, are pariahs. ... Sending emigrants to the Congo in order for them to reconstruct their lives equals condemning them to the destiny of natives' ${ }^{40}$ In Southern Rhodesia, the new state authorities took an extremely sceptical view of immigrants, driven by fears of the "poor white" problem. This was underpinned by concerns about the perennially depressed condition of the economy and thus the need to protect white Rhodesian unemployed. In the 1930s Rhodesian Prime Minister Huggins quite explicitly articulated the view that Rhodesia could not absorb large numbers of white immigrants; settler society was not under immediate political threat and Huggins's view was that that a large white working class would, dangerously push for high wages and seek to exercise political power. ${ }^{41}$ Portuguese policy towards immigration to the colonies in the 1930s was focused on sending technical cadres, engineers, specialists and managers. Those wanting to emigrate to the colonies on a private basis had to show a high income or an invitation guaranteeing employment. This approach was driven by the fear of creating a stratum of unemployed and poor whites. ${ }^{42}$

Even when such policy was reversed, as it was in the Portuguese colonies from the late 1940s to the end of the colonial period, there was often dismay at the actual settlers who materialised. A Portuguese official report in 1970 concluded that

The settler who comes to [Mozambique] ... is of such a modest social and economic standing that he is frequently more of a disruptive element than a useful one. With a happy few exceptions [these settlers] show themselves completely lacking in any skills, and are largely difficult, if not impossible, to keep on the virtuous path (particularly those that arrive clandestinely). The majority lacks the mentality to secure their livelihood, much less to be attentive to their civilizing function with respect to the native population. ${ }^{43}$

It was only after the Second World War that Portuguese and Rhodesian leaders warmed towards immigration. Under new pressure in a decolonising world, and with more money to spend as a result of the post-war boom, they were 
now ready to put racial demographics ahead of considerations of how to manage the white lower orders. There was a temporary explosion of the size of the white population in the region outside South Africa, from about 200,000 at the end of the Second World War, to approaching a million at the start of the 1970s. Southern Rhodesia moved from only 69,000 whites in 1940 to 27,100 in 1970 , and Northern Rhodesia from a paltry 13,000 in 1940 to 75,000 in 1960. Most proportionately spectacular though was the growth of the white population of the Portuguese colonies. In 1940 there were under 100,000 whites in Mozambique and Angola combined. By 1970, there were at about half a million and possibly more, roughly 60 per cent in Angola and 40 per cent in Mozambique. ${ }^{44}$ In addition, by the early 1970s there well over 100,000 Portuguese troops in Angola and Mozambique.

In the future South Africa, the great inflow of British settler population occurred under the impetus of the gold mining expansion of 1890 to 1906. After the formation of the Union in 1910, state immigration policy was largely hostile to immigration. Afrikaner nationalists feared that British immigrants would oppose them at the ballot box, and elites in general feared the import of working-class radicalism. There were only two moments of large scale United Kingdom immigration. In the immediate aftermath of the Second World War, the Smuts government turned towards immigration from Britain and elsewhere in Europe, but the Nationalists quickly shut down this policy after coming to power in 1948. In the early 1960s, a shortage of white artisans led to a modest opening to British immigrants. A large proportion of these were artisans. Stone's study of this cohort suggested that contrary to stereotype, they were by and large not reactionaries attracted by apartheid, but rather were pursuing economic opportunities. He showed they tended to absorb South African racial attitudes fairly quickly, but that they were notably sympathetic to trade unionism, including for black workers. ${ }^{45}$

Intra-regional white migration is a phenomenon that needs to be better understood. As Robert Bickers usefully suggests, this "unsettled" dimension of supposed "settler" life is worth investigating. ${ }^{46}$ The world of the British Empire was often one of searches for short-term opportunity rather than long-term settlement. "Settler" is a misnomer for such a strikingly unstable social category of trans-imperial sojourners. Two instances of this are worth particular comment. One is the peculiar turbulence of Rhodesian migration. Rhodesia always had a huge immigration turnover. South Africans and Britons especially, flowed in and out with remarkable velocity, throughout the life of the Rhodesian state. ${ }^{47}$ They appeared remarkably sensitive to the pushes and pulls of Rhodesia's highly changeable economic and political prospects. Another is the history of Portuguese migration to South Africa, mainly via Mozambique. ${ }^{48}$ Starting with the flow of mainly very poor Madeirian workers, often working under conditions of mutual exploitation in fellow-islanders' market gardens that fed South African cities, it developed through a more gradual and socially differentiated migration of mainlanders through the post-Second World War period. It culminated in the mass migration following the collapse of the empire which made 
a significant impact on South African cities. Portuguese immigrants formed a number of communities in South African cities, most notably in Johannesburg southern suburbs areas like Turffontein, La Rochelle and Rosettenville. Though many had lost everything in the collapse, over time they were able to get upwards social mobility through success as artisan skills and small business. Across the whole period, South African resistance to Portuguese migration was considerable, and certainly informed by anti-Catholic religious ideologies.

\section{Struggles for cultural dominance}

The white working classes of Southern Africa were a field of struggles for cultural dominance. In the British Empire countries there can be little doubt that, early in the twentieth century, imperial elites were determined to impose their cultural hegemony on whites and indeed to a considerable extent on blacks. However, British working-class immigrants also brought their subaltern cultural institutions, organisations and practices, from dog racing to fraternal organisations. And even by the 1920s, with the arrival of the silent movies and the spread of the gramophone, the challenge of American influence on white workers was bothering both Afrikaner and Anglophone elites.

In South Africa, Southern Rhodesia, and the emerging enclave of white labour on the Northern Rhodesia Copperbelt, there was a stabilisation and quasi-indigenisation of the British models of working-class life that had been brought to the region by the mass migration of the 1890 to 1906 . The apprenticeship system and the pivotal position of artisans in industry and services had become very firmly established. The artisan world was initially British dominated to a massive extent, with a large majority of "skilled men" being immigrants as late as the 1920s. This created a tension between artisan unions and the new Afrikaner workforce. There were also quite a number of "Coloured" qualified artisans, trained in the Cape. Over time however the system became both more racialised and more Afrikanerised. A specifically artisan culture stamped a number of the industrial towns of the area. Bulawayo, as the Rhodesian rail and industrial centre, was perhaps the classic example, with its white skilled workers clubs, communal activities and even a labour movement store, and the Rhodesian Labour Party dominating electoral politics in working-class areas. ${ }^{49}$ The British artisan tradition had a last wave of reinforcement with the $1960 \mathrm{~s}$ emigration to Southern Africa. In 1960s Johannesburg, British artisans were a visible presence; soccer and dirt track motorbike racing flourished, popular British television personalities made tours, and the Daily Mirror was the standard reading in Johannesburg barber shops.

The region saw two spectacular attempts to impose cultural autarky on the working class. These were the projects of the Portuguese Estado Novo and of Afrikaner nationalism. Both were anti-modernist at a cultural level, while at the same time being invested in the idea of technological modernity. And both had a particular emphasis on shielding subaltern whites from the supposedly disintegrating effects of cosmopolitan culture. Both offered workers a nostalgic 
vision of an idealised rural world. In the long run the subaltern whites who they were intending to protect succumbed to external forces, in particular, the power of Americanised global consumer culture.

An extraordinary example of this cultural anti-modernism was the attempt by the Portuguese to establish model agricultural colonies in Angola. Based on a fantasy of the idealised virtues of the Portuguese peasantry, it aimed to set up villages which would not only embody Catholic and authoritarian political ideals, but also provide African peasants with a model of how farming should be carried out. In the areas of Cela and Cunene peasant families and extremely poor rural workers from the metropolis were settled. But they faced harsh conditions and the planning of the projects left much to be desired. Many of the farmers gave up, drifting into the towns, where they worked in low level civil service posts, office jobs or as petty traders ${ }^{50}$ But the vast majority of settlers came at their own initiative, albeit with state encouragement, and chose to settle in the cities, where the hegemony of Salazarism gradually weakened. In Angola, by 1970, 77 per cent were urban. In Mozambique, the influence of consumer culture on Lourenco Marques became very strong via the South African tourist presence and commercial connections to Johannesburg. And also cutting against cultural conservatism, the vast scale of Portuguese migration to France during the 1950s and 1960s diffused dissident ideas into the home country and thence into the colonial world.

During the 1950s and 1960s, amongst Afrikaners a high level of social discipline and cohesion was ensured through the incorporation of working-class and lower-middle-class Afrikaners into a network of organisations designed to regulate every sector of life, from women (Vrouefederasie) to youth (Voortrekkers). But these attempts to round up whites into a volk culture were constantly threatened. Already in the 1950s, the state was worried though about white working-class youth groups like the "Ducktails", whose blend of British and American rocker youth styles, drug taking, blurring of racial boundaries in clubs and casual violence made them a prime example of what officials feared about cultural globalisation..$^{51}$ While the degree of upwards class mobility in this period has probably been overstated, the size of the improvement in white working-class living standards had been underestimated. White real wages in manufacturing and construction doubled between 1948 and 1972, and in mining by only a little less. ${ }^{52}$ The new consumption patterns this enabled changed white working-class life. Near-universal car ownership enabled families to enjoy new leisure activities like the drive-in cinema, roadhouse meals and seaside holidays. ${ }^{53}$ “Ag Pleez Daddy," Jeremy Taylor's famous song of the early 1960s, reflected the contempt of Johannesburg's Anglophone bourgeoisie for the new affluence of the white workers, sending up their outings to the "bioscope" (cinema), funfair, the wrestling and trips to Durban ('only eight hours in the Chevrolet'). But such snobbish resentment was surely scarcely noticed by its targets. The Afrikaner cultural organisations and reformed churches, with their strong association with the political establishment, over time lost their appeal to the working class. By the 1980s the growing preferences of Afrikaner workers 
for Country and Western over Boeremusiek and Pentecostalism over the Dutch Reformed Church were apparent. These were important and serious issues, because the viability of the political projects of state leaders and of activists to an important extent stood or fell by the ability to marshal political identities. And while in theory extreme white right wingers looked back to a golden age of ethnic identity, social unity and conservative discipline, in practice they were susceptible to the cosmopolitan attractions of casino gambling, American television sitcoms and videotape pornography.

\section{Endings: workers between Racial Keynesianism and free marketism}

In our contemporary global perspective, free market ideology is the favoured viewpoint of those who are indifferent or hostile to issues of racial and class equality, whereas more racially and economically egalitarian political actors tend to support interventionist policies. By contrast, in twentieth-century white-ruled Southern Africa, both free market and statist economic policy was harnessed in various ways to racial domination, with economic interventionism being particularly favoured by white populists. One might characterise this phenomenon as Racial Keynesianism.

The Botha-Smuts governments of 1910 to 1924, the Estado Novo before 1945, and the political regime of pre-Second World War Southern Rhodesia, did relatively little for the white working class. In contrast, as we have seen, South African governments from 1924 took an interventionist course, with favourable, racially discriminatory outcomes for the white workers. This lead was followed by settler governments in the Rhodesias and the Portuguese colonies after the Second World War. These regimes moved in an increasingly white-welfarist direction and poured money into employment-generating prestige projects, whether dam building, the development of airlines, road construction or the establishment of new schools and universities.

However, in the end, the elites abandoned the white working class. In Portugal, during 1974-5 the new, democratised state moved quickly to depart from Africa, leaving the colonial white workers to their own devices. From 1974 to 1975 , when Ian Smith began negotiating seriously with African nationalist leaders, Rhodesia rapidly moved away from white worker protectionism. The protests of extremist groups like the Rhodesia Action Party failed to prevent the ultimate transition of power. ${ }^{54}$ In South Africa, the growing Afrikaner middle class were increasingly uncomfortable in the embrace of the populism. They aspired to globalised patterns of consumption and acceptance by their metropolitan peers. They gradually lost their social connections to the white working class. Moreover, white business was aware that the low black consumption levels and labour shortages which apartheid had produced were strangling the economy. The leaders of the National Party found the sacrifice of the special privileges of the white working class increasingly easy to contemplate as part of their search for solutions. One after another, regulations and laws protecting 
white workers began to be reversed. The rapid increases in white working-class standards of living of the previous period were not sustained: white real wages fell substantially from the second half of the seventies. ${ }^{55}$ As black trade union movements became powerful, white workers faced challenges to their racial authority from their black counterparts. A palpable sense of dislocation existed amongst white workers, finding expression in support for the parties of the extreme right: but ultimately their resistance to the move away from apartheid was to be of no avail.

\section{Conclusion}

In Southern Africa, "the white working class" and the "poor whites" were neither simple sociological categories, nor ones that can adequately be thought through within the boundaries of individual states. Who white workers and poor whites were, and what their significance was, was an endlessly refought political battle. They did not live in single national space but moved across the region. Their concerns were not purely parochial but related to transnational politics. They should perhaps be thought of not so much as "white people", as but members of particular classes who were called "white", by others, or by themselves, for particular ends, in distinct moments of global, regional and local historical time.

\section{Notes}

1 Fetter, Creation of Elisabethville, 66-68; Perrings, Black Mineworkers in Central Africa, 50-53; Report by D.I. Jones to Comintern, 13 August 1921, Davidson, Filatova, Gorodnov and Johns, South Africa and the Communist International, 87; Sidney Ball, 'Belgian Congo', Engineering and Mining Journal, 22 January 1921, 191.

2 Russell and Russell, Afrikaners of the Kalahari, 24-26.

3 Brás, 'The Twists and Turns of Life', 148-160.

4 Katz, Trade Union Aristocracy; Krikler, White Rising.

5 O'Meara, Volkskapitalisme, 78-95.

6 Morrell, White but Poor is a key text.

7 Boonen and Lagae, 'A City Constructed', 59.

8 See Stoler, 'Rethinking Colonial Categories'.

9 Notably in Bender, Angola Under the Portuguese.

10 Pimenta, 'Angola's Whites'.

11 Errante, 'White Skins, Many Masks', 21-22.

12 According to Lubkemann, 'Unsettling the Metropole', 265-266, Portuguese citizens returning from the colonies in 1974-1975 has a significantly higher level of education and employment skills than their metropolitan counterparts.

13 Crankshaw, Changing Division of Labour, 141-171.

14 Pimenta, 'Angola's Whites', especially 178.

15 Errante, 'White Skins, Many Masks'.

16 Crankshaw, Changing Division of Labour, 141-177.

17 Penvenne, 'Labor Struggles at the Port of Lourenco Marques'.

18 Clarence-Smith, Third Portuguese Empire, 1825-1975, 178.

19 Ribeiro de Menzes, Salazar:A Political Biography.

20 Harvey, 'Counter-Coup in Lourenco Marques'. 
21 Fetter, Creation of Elisabethville, 68-71, 97, 101, 173.

22 Giliomee, The Afrikaners, 336-345.

23 Leys, European Politics in Southern Rhodesia, 180-185; Lowry, 'Rhodesia 1890-1980', 113-149.

24 On Anderson, and poor whites more generally, see Cairnie, Imperialists in Broken Boots.

25 Schwarz, Memoirs of Empire, 361-363.

26 Welensky, 4000 Days, 21.

27 Hyam and Henshaw, Lion and the Springbok, 208-227. Also interesting on the politics of the Afrikaner presence in the Rhodesias in this period is Winch, 'Rhodesia, Rugby and the Afrikaner'.

28 My original statement of this position can be found in Hyslop, 'The Imperial Working Class', 398-421.

29 Lunn, Capital and Labour, 90-96; Phimister, 'White Miners in Historical Perspective'; Henderson, 'White Populism in Southern Rhodesia'.

30 Money, 'The World of European Labour'.

31 Lunn, Capital and Labour, 93.

32 Van der Walt, 'Transnational Labour Activism in Southern Africa, 235.

33 For McPherson see Walker and Weinbren, 2000 Casualties, 204, 300, 324-326, 335; for Maasdorp see Steele, 'White Working-Class Disunity'.

34 Roos, Ordinary Springboks.

35 Money, 'The World of European Labour', 235-239, 248-251.

36 Clarence-Smith, Third Portuguese Empire, 178.

37 Hepple, Verwoerd, 66.

38 Schwarz, Memories of Empire, 367-377.

39 Lowry, 'The Impact of Anti-Communism'.

40 Boonen and Lagae, 'A City Constructed', 55.

41 Mlambo, White Immigration into Rhodesia, 44-45.

42 Castelo, 'Reproducing Portuguese Villages', 272.

43 Errante, 'White Skins, Many Masks', 20.

44 The statistics for the region are usefully brought together in Pimenta, 'Angola's Whites', 171.

45 Stone, Colonist or Uitlander; see 197 for views on trade unionism.

46 Bickers, Empire Made Me, 242.

47 Mlambo, White Immigration into Rhodesia, 5.

48 Glaser, 'Portuguese Community in South Africa'.

49 Ranger, Bulawayo Burning, 31-38.

50 Castelo, 'Reproducing Portuguese Villages', 267-281.

51 Mooney, 'Ducktails, Flick-knives and Pugnacity'.

52 Lipton, Capitalism and Apartheid, 409-410.

53 Beinart, Twentieth Century South Africa, 179-190.

54 Godwin and Hancock, Rhodesians Never Die.

55 Lipton, Capitalism and Apartheid, 409. 


\title{
2 Rhodesian state paternalism and the white working-class family, 1930s-1950s
}

\author{
Ivo Mhike
}

\section{Introduction}

The 1930s witnessed Southern Rhodesia's most severe socio-economic problems since colonial occupation in 1890, giving rise to new state social engineering initiatives about family and children's education which influenced policy into the 1960s. The Great Depression engendered a poor and reprobate class of white juveniles whom the state viewed as an ominous sign of the cataclysmic rupture of white settler family and its values. It undermined the capacity of the working class to reproduce itself; white parents were unable to raise children with the skills and character to work for and defend the colony. More broadly, the condition of the white family violated the sustenance of "white standards" of living, the prestige of the white race and the hegemonic discourse of colonial control. "White standards" were discursively constructed in colonial Rhodesia. All whites were expected to live up to the self-proclaimed superior culture by virtue of being white. They were supposed to be better educated than Africans, occupy superior positions in the workplace and be able to access and afford the material goods manufactured for Europeans. Their possessions and behaviour were supposed to be markedly different from that of Africans. The 1929 Children's Protection and Adoption Act provided the framework for state intervention in youth rehabilitation and child welfare programmes for several decades following its promulgation. This followed a stern warning in 1928 from Southern Rhodesia's first female legislator, Ethel Tawse-Jollie, saying that, 'We [the state] cannot rely on parents of this country to do their duty invariably in regard to these children'. State exasperation with white parents to fulfil their duty in regard to their children pushed state policy into paternalism after 1930.

This chapter considers the history of Rhodesian state paternalism towards the white working-class family regarding the upbringing of white children (education and maturity) as part of building a robust colonial white society and preserving empire. The colonial state maintained considerable influence on the white family since the inception of colonial settlement in the 1890s. However, the 1930s saw the emergence of a multidimensional socioeconomic crisis, characterised by high unemployment amongst white youths and the breakdown of the family unit. In response, state policy morphed into a multifaceted, 
intrusive and coercive state welfarism. White settler desire to maintain a multigenerational model of colonial development resulted in state solicitude over the education of white children. This study analyses the establishment of state welfarism under the Children's Protection and Adoption Act (1929) with a bias towards state guardianship in state-run child institutions. State control of white children to provide skills education and mould character for white maturity were key in the reproduction of the white working class and in building a robust colonial white society in Africa.

This study uses the 1929 Children's Law as a lens to understanding the transformation of state ideas about education and maturity for children from poor and "degenerate" backgrounds. In juvenile rehabilitation homes and other land schemes, the Rhodesian government sought to engineer a white youth who was "rural minded"; who was willing to take up jobs in agriculture or became a future farmer. The curriculum at St Pancras's home for delinquent boys, established in the town of Bulawayo in 1936 in response to an upsurge in delinquency cases, reflected the 1930s government thrust of practical skills training for blue-collar jobs. State programmes under the Children's Protection and Adoption Act revealed colonial authorities' anxiety about the development trajectory of white society, and state ideology of preservation was aimed at achieving three main objectives. The first of these was to prepare white children from the lower classes for a social educational model that was responsive to the productive needs of the economy, departing from the elitist educational model for whites which had, hitherto, been used. Secondly, it was to manage those who could not meet white expectation by setting the moral and social tone of white society in line with the state's vision of ideal colonial society. Thirdly, it was to sustain a robust colonial society and consolidate the Empire. Rhodesian white society was ossified to a considerable degree and the family welfare programmes and child rehabilitation were intended to restore the normative values for social cohesion. The state had intrusive powers over white society through the surveillance of the white working-class family and laying out penalties for violations to child rights. In addition, Rhodesian state usurpation of child guardianship aimed at ensuring the proper values in children could be likened to the controversial colonial separation of indigenous children from their parents in Australia and Canada. ${ }^{1}$ In the same way that colonists in the dominions did not want native children to inherit their parents" "savagery", the Rhodesian state wanted to save white children from their parents' "degeneracy".

This chapter reflects on state fears and ideas, and the extent to which it was prepared go in order to preserve a racialised system. The state saw its necessary to act as "parent" to certain groups of whites who failed to meet its expectations. However, by shepherding these groups, the state subverted its own legitimising ideology of white supremacy and minority rule by demonstrating that not all whites were superior and autonomous. This chapter also speaks to broader debates about how states intervened in the lives of children in colonial settings by forcibly removing white children from their parents. 
It was a universal colonial claim that unregulated youth development threatened both national and imperial demise. ${ }^{2}$ In the structuring of white communities and the problem of poor whites in white settlements, particularly in Southern Africa, children were deemed particularly vulnerable to cultural contamination. State officials were anxious about so-called "evil" home influences, which referred to, amongst other things, failure by parents to provide their children with food and shelter, "drunkard" parents, "immoral" mothers living with multiple men, exposure of children to "cultural contamination" (racial mixing of all forms), begging and prostitution. ${ }^{3}$ The years before adulthood made a significant difference in producing either the next generation of responsible citizens, national leaders, heads of family and good mothers, or moral and physical degenerates. ${ }^{4}$ The 1929 law indicated that the state viewed white children not as mere possessions of their parents but as individuals in their own right whose future was inseparable from that of the state and empire.

This study is largely based on the Rhodesian colonial archive housed at the National Archives of Zimbabwe, Harare, generated by various proto-civil organisations such as the Child Welfare Society and government departments, particularly the departments of Education and Social Welfare. The colonial archive is a rich repository of state programmes on poor and "degenerate" families. However, the power relations were so paternalistic that categories like the poor, children, and "degenerates", amongst others, did not have a voice and were often spoken for by the state. This top-bottom structure of the narratives limits our understanding of the views, attitudes and perceptions of these categories of people towards state programmes of rehabilitation and self-preservation. Those who operated on the fringes of state-defined parameters were objects of the state gaze and seldom had a voice. However, these sources are important in that they articulate government programmes and the intended outcomes allow for appraisal of government initiatives.

\section{State and the Rhodesian white settler family, c. 1900-1930}

State paternalism toward the white family was forged in the history and nature of Rhodesian white society. In 1890, Cecil John Rhodes and the British South Africa Company (BSAC), through a British Royal Charter, established commercial interests over the Zimbabwean plateau. In the first two decades of settler colonial occupation, the white population was highly transient and remained so to varying degrees for the duration of the colonial period. ${ }^{5}$ As a response, the company government actively encouraged white immigration and settlement to exploit the natural resources (land and minerals) of the territory. At the turn of the twentieth century, the government encouraged immigration of white women and settlement of families because the Rhodesian pioneers were largely freebooter white males. ${ }^{6}$ Rhodesia aggressively pursued demographic engineering through immigration policies that actively courted Europeans to come and settle permanently north of the Limpopo. ${ }^{7}$ White immigration was politically vital to the state because it sought to stabilise a white population for 
administrative purposes as well as to sustain a sense of nation. ${ }^{8}$ Migration in settler colonialism involved permanent settlement, creating a sense of sameness, and the attempts by the settler or colonist to remake his society in the new place. ${ }^{9}$ In the Rhodesian context, European immigration was a facet of wider economic policy and national development.

The white family unit became an essential tool in developing a specific set of values upon which Rhodesian settler society was based, and the settler state actively assisted in family welfare. For example, Ordinance 19 of 1904 was designed to prevent destitution of and provide for the relief of wives and families (children) that had been deserted. ${ }^{10}$ Rhodesian state policy was designed with a view to encouraging young white families to choose to settle in Rhodesia over other territories of British settlement such as Canada, Australia, New Zealand and South Africa. ${ }^{11}$ There were other regulations that incentivised the settlement of families and child rearing. For example, married white men in the civil service received a family allowance to cushion them from economic hardship because the Rhodesian cost of living was higher compared to that of neighbouring South Africa. ${ }^{12}$ Civil service regulations also encouraged the employment of unmarried women only. A woman was supposed to resign upon marriage to concentrate on her domestic duties, particularly the raising of children. These regulations were inspired by Victorian domesticity, which confined women to the physical space of the home. Rhodesian society regarded domesticity and motherhood as sufficient emotional fulfilment for females. ${ }^{13}$ In colonial societies, women were perceived as mothers of the imperial race, as symbols of moral chastity and beauty, and conduits of good behaviour. ${ }^{14}$ As such, Rhodesian society also shaped women's gender roles for the sustenance of an ideal society and these defined motherhood as key to national and imperial success.

Child bearing and child health were state priorities in Rhodesia. The first white child born in colonial Rhodesia was Cecil John born to the Tullochs of Umtali in August of 1891 and by the 1923 census, the "second generation" of Rhodesians numbered some $8,308 .{ }^{15}$ The colony's post-World War One birth rate improved from 27.85 around 1918 to 31.10 per 1,000 by 1923 . Natural population increase was critical in propagating Rhodesian values and would arrest the transient nature of the white population in the colony. In order to consolidate the improving birth rate, the government appointed a Medical Inspector of Schools for the systematic examination of children to improve child health. The Inspector identified the tropical disease malaria, dental hygiene and eye diseases as constituting a risk to child health. The Medical Inspector suggested the establishment of school clinics and feeding schemes so that there would be no need to hesitate bringing a young family to the country because of health concerns to would-be immigrants. ${ }^{16}$ In view of this fact, the Rhodesian state was solicitous about the welfare of white children with whom the future of the colony rested. The post-1930 period would test the state's resolve in child welfare and the reproduction of white dominance in a colonial setting. 
The colonial education policy was linked to Southern Rhodesia's efforts at creating an international image of itself as a colony conducive to family life by providing a competitive system of education comparable to any in the world. ${ }^{17}$ Colonial education transformed significantly during the first three decades of white settlement. In the 1890s provision of education was the responsibility of religious bodies. The Education Ordinance of 1899 enabled the creation of an Education Department and in 1903 government-aided schools were introduced. ${ }^{18}$ In 1907 some 50 per cent of white children of school-going age were receiving some form of education. ${ }^{19}$ However, by the 1920 s Southern Rhodesia had a relatively well-structured system of schools involving state-aided, state controlled and denominational schools. In 1923, some 6,000 white pupils were in school at an average attendance of 88 per cent. ${ }^{20}$ In 1930 the Southern Rhodesia Compulsory Education Act was passed making white education compulsory for children between the ages of 7 and 15 years.

\section{Unemployment, racial and cultural contamination}

The 1930s and 1940s saw economic insecurity, the imperial ideology of white supremacy, and colonial fears of racial "degeneracy" collide in real time. The honeymoon of relative economic and social stability that Rhodesia had enjoyed since the turn of the century evaporated, giving way to unprecedented white unemployment which exacerbated state fears of white "degeneracy". The Great Depression of the 1930s and the ensuing economic and social shocks transformed the social fabric of Southern Rhodesian society. Thousands - black and white - lost their jobs in industry and commerce due to viability crises, farmers were forced off the land as commodity prices fell, and national income plummeted. The onset of the depression and the fall of commodity prices saw cotton and tobacco farmers moving to maize production to offset losses, but between 1930 and 1931 maize prices also dropped from 10 to 4 shillings per bag. However, the production cost remained at 8 shillings per bag. In addition, Southern Rhodesia's national income fell from \&13.9 million to $£ 8.7$ million between 1929 and 1931. ${ }^{21}$

Even more frightening for Rhodesian authorities, the period raised the spectre of the "poor white" problem. In 1932, of the 21,500 settler wage earners in Southern Rhodesia, 8 per cent or 1,720 were unemployed. ${ }^{22}$ In 1933 , a conservative estimate placed white male unemployment at 830 , of whom 400 were married men. ${ }^{23}$ Rhodesian white male poverty was the source of a strong strain of disillusionment because society perceived them as breadwinning patriarchs whose duty it was to provide for their families and uphold white prestige. Loss of jobs resulted in economic insecurities that created "unwholesome" home and social environments that incubated youth delinquency. ${ }^{24}$

The ranks of the unemployed also included youths who were leaving school and could not find job vacancies. The question about white education was no longer one of access to education because the Compulsory Education Act (1929) had resolved this issue. The pertinent question became the relevance of 
a general education and its suitability and desirability to the changing needs of the economy. ${ }^{25}$ From the 1900 s, white education was elitist and aimed to prepare white youth for the civil service, but by the 1930s the public service could no longer absorb all the school leavers. The colonial economy was no longer a useful place for those generally trained for white-collar jobs. Youths had to prepare for blue-collar jobs if they were to keep the mantle of safeguarding white civilisation and carry the settler's mission in colonised lands. ${ }^{26}$ However, the competitive edge of white youths over Africans was compromised by their lack of practical skills. From the outset, Africans were taught practical skills for manual labour. Statistically, about 369 white pupils left school at the end of 1931 and this figure was far less than the annual average of $700 .{ }^{27}$ The Director of Education speculated that the 1931 figure was lower than usual on account of parents keeping their children in school because there were no job vacancies. $^{28}$ In 1932, some 341 white youths left school and 247 required work. ${ }^{29}$ The remaining 94 (28 per cent) entered higher education or left the colony. By May of 1933, some 91 white youths still required employment. ${ }^{30}$ Such statistics vindicated suggestions that there should be a "weeding out" of children who did not have the capacity to proceed to higher education and fill posts requiring such an education to avoid the state wasting resources on a general higher education. ${ }^{31}$ The 1934 report of the Labour commissioner further emphasised that the school system was producing insufficiently equipped youths and this was reflected in the data relating to unemployed adults. ${ }^{32}$ Sections of white society blamed this development on the calibre of the Rhodesian teacher who was a product of England's public school system who found a rural life and the challenges of mining unattractive. ${ }^{33}$

Unemployment, poverty and lax parental control combined to incubate youths who were not amenable to parental control and some who flouted racial restrictions. White children had to be lifted from the morass in which their parents had sunk if the dream of a multigeneration model of colonial development was to be sustained. Rhodesian state paternalism was rationalised to perform the function of guardian in place of "failed" parents. However, it was underpinned by local and Empire-wide anxieties. In the wake of the First World War, imperial authorities noted with concern the low birth rate and poor health of children. ${ }^{34}$ There was a worry in the British Empire about efficiency and decline marked by the South African War (1899-1902) and to a degree the ravages of First World War and the Spanish influenza. Although "degeneracy" was not defined in physical terms but in terms of astuteness of character and qualities to sustain imperial control, the ravages of war and disease did not go unnoticed. Ideas about imperial decline were particularly worrying for Rhodesia because the colony was trying to boost its population and firmly establish a settler colony predicated on specific values. Rhodesian legislator, Lionel Cripps, had earlier warned that, 'The white men were the aristocrats of this country and it behoved them to keep that position for themselves'. ${ }^{35}$ The state harnessed its coercive apparatus and increase its bare-faced paternalism in order to reproduce appropriate settler values. 
In the harsh economic environment of the 1930s, the Rhodesian state recognised juvenile delinquency as a social problem. Juvenile crime was most suggestive of the erosion of white values and incipient social disarray because white children did not exhibit the "aristocratic" values needed to sustain white dominance. Officials took the correlation of poverty and deviance as the basis for identifying delinquents and potential delinquents. Children from poor families were viewed as potential delinquents because they lived on the fringes of white society and, therefore, did not conform to the ideals of whiteness. In 1931, the director of education observed that poverty amongst whites resulted in parents' failure to provide for their children and such children developed delinquent tendencies with the most common offence being theft. Other offences included malicious injury to property, assault and housebreaking. In particular, delinquency labels were attached to children from large poor families who were in receipt of government rations and considered likely to indulge in delinquent behaviours. ${ }^{36}$ In 1932, representatives from the CID, Department of Education and Department of Justice submitted to the government a document on the incidence of juvenile delinquency. ${ }^{37}$ Although the report did not provide any statistical data, it identified poverty and lax parental control as common denominators in the identified cases. ${ }^{38}$ In this respect, juvenile delinquency was framed as a lower-class white problem and common mischief amongst white children from poor families was likely magnified as a harbinger of delinquency.

Eugenic rhetoric aided the Rhodesian discourses of "degeneracy" and juvenile delinquency which formed the basis for state intervention in the white family. Colonial eugenic thinking manifested itself not in the direct importation of metropolitan practices such as sterilization, but in a translation of the political principles and social values that eugenics implied. Eugenics helped identify a range of roles including gender-specific work and productivity, described in social, medical and psychiatric terms. Applied to colonial Rhodesia, eugenics defined white maturity and how white children should be brought up and with whom they should socialise.

The Rhodesian state also framed white poverty as a harbinger of white social and cultural contamination. Through the influences of social Darwinism, inferior races were believed to have a contaminating effect on superior ones and, in particular, poor whites had to be rescued to preserve the purity and superiority of the white race. ${ }^{39}$ In 1931, the Rhodesian Criminal Investigation Department (CID) at Que Que recommended that Douglas (13) and Ronald (9) be considered for a proposed Industrial School largely because, 'it is well known that these children mix with natives in play, and are not cared for as they might be by their parents who are in receipt of government rations and are in a very poor way (sic).${ }^{40}$ In a similar report from Bulawayo, juveniles Peter and James Quinn were deemed "out of control". However, what worried authorities the most was that, 'they frequent native compounds and return with Bicycles Cigarettes [an African brand] and other articles'. In addition, 'they beg or steal these from natives as they have no money to buy them' ${ }^{41}$ While theft was socially abhorred and legally punishable, Rhodesian authorities regarded stealing from Africans 
as sacrilegious in a colonial context where perceived white superiority was sometimes synonymous with infallibility. Stealing from Africans by a member of a "superior" white race transgressed racial, cultural and legal boundaries of colonial society. In this respect, poverty increased white social indecorum and the Rhodesian state had to protect white children from struggling poor families in order to secure the future of the white race.

\section{The state and child guardianship}

The Children's Protection and Adoption Act of 1929 became a quintessential instrument of state control over the white family. Initially promulgated to align Rhodesian child law with that of South Africa, white unemployment and suggestions of the emergence of a "poor white" problem in post-1930 Rhodesia changed the functional nature of the new law. The law came in handy for the state when white parents could not fulfil their obligation over child welfare. The law consolidated state control over white children by giving the courts the power to remove a child from the custody of its parents where certain offences were committed and passing the parental rights either to a relative or to the state. ${ }^{42}$ This provision protected children against the so-called "evil" home influences, which referred to, amongst other things, parental failure to provide food and shelter, "immoral" mothers living with multiple men and exposure of children to racial and cultural "contamination" through begging and prostitution. ${ }^{43}$ However, being poor was enough of an offence for a parent to lose custody. Furthermore, the law sought to minimise the plight of illegitimate white children by providing a mechanism where their status could be legitimised in relation to their parents in line with British law.

The transfer of guardianship largely targeted poor families. The case of the Van der Zandt family typified state paternalism under the Children's law. This was a large family of seven children whom the authorities declared "poor white" because they were in receipt of government relief. In addition, the family was squatting on a piece of alienated land allocated by the Lands Department. ${ }^{44}$ Officials ruled that 'in their interest and the interests of the state', the Van der Zandt girls Johanna (15) and Aletta (13) ought to be sent to an established institution away from their parents to protect them from a poor home environment. ${ }^{45}$ This resonated with state recommendations for Douglas, Ronald and the Quinn brothers mentioned earlier. Practically, the state had assumed control over these children because it judged the parents unable to bring them up in a proper way that upheld "white standards". Rhodesian white society believed that unregulated female child development increased the likelihood that young women would cross the racial divide in their sexual associations. Interracial sex and miscegenation represented the worst form of racial and cultural contamination in white Rhodesia. For the male child, he had to be trained to become a breadwinning patriarch and support a family.

The term "Children In Need of Care" enshrined in the Children's Law encompassed a broad spectrum of "delinquents" and female children who were 
labelled as children in "Moral Danger" and these were identified through the courts and were housed in certified institutions by the authority of the magistrate. The 1929 law established a probation system, formation of juvenile courts, places of safety, government Industrial Schools and other certified institutions for the broad category of "Children In Need of Care", particularly those with no homes and who were not under proper parental control or were subject to immoral influence. Such children had to be sent to certified institutions until they were 18 years of age. ${ }^{46}$ The Probation and School Attendance Officer Sydney Caley, appointed in 1936, acted as guardian ad litem.

State policy of usurping child guardianship contradicted Rhodesia's decades-old white immigration policy that portrayed the colony as a conducive environment for young families. But in the crisis of the 1930s such radical measures were deemed necessary in order to save white society from imminent collapse. Beginning in 1936 the Southern Rhodesia Education Department operated machinery for dealing with neglected and delinquent children under the age of 16 . This comprised several orphanages, boarding houses (with facilities for clothing indigents and boarding them during holidays), working boys and girls hostels, and a moral welfare home for the senior girls and a home for delinquent boys. By 1939 government-certified institutions for destitute and maladjusted white children included St. Joseph's and Rhodesia Children's Home Orphanage (Salisbury), Daisyfield Orphanage (predominantly Afrikaner), and St Clare's Home for white juvenile mothers (Bulawayo).$^{47}$ There were other institutions operating on government grants which received children through the voluntary committal process. This network of institutions or "Places of Safety" provided alternative home environments and propagated good moral values.

\section{Agricultural training in a state certified institution}

\section{St Pancras home for delinquent boys, 1936-1940}

The 1930s-1950s spawned a precipitous trajectory of "white men and boys who lacked the education, discipline and diligence necessary to raise white families' and these 'were perceived as an internal threat to settler visions of multi-generational success' and a liability to the colonial fiscus. ${ }^{48}$ In particular, the white male child was regarded as the defender of colonial establishment and imperial designs. According to Stephanie Olsen, the white boy had upon his shoulders the safeguarding of civilisation and carried the white settler's mission in colonised lands. ${ }^{49} \mathrm{With}$ problems in industry and commerce, the state sought to produce breadwinning patriarchs by fostering a 'rural-mindedness' in male youth for agriculture sector jobs, providing instruction in elementary engineering, woodwork and metalwork. This would increase the number of whites on the land and create new avenues of youth employment. More broadly, the new educational model was enmeshed with the colony's long-term goal to build a white skills base for future industrial development as well as establishing an 
artisanal class that would serve as a bulwark against the economic mobility of Africans to the higher echelons of the colonial economy. ${ }^{50}$

St Pancras home for delinquent boys was established in 1936 near the town of Bulawayo and was run by the Education Department in partnership with the Church of England. The state intended it to be a hybrid institution which combined behavioural reform and industrial training because boys at St Pancras represented all that the colonial officials feared in white male youths: a calibre of male youth who could not mature to support a family. Rehabilitation started with the very location of St Pancras. The director of education recommended a country location as the ideal environment for juvenile rehabilitation and effective control of delinquents as opposed to an urban one. The urban environment and working-class culture were believed to have a morally corrupting influence on children and a country environment was envisioned as most ideal in the process of rehabilitating the delinquent. ${ }^{51}$ In the case of Victorian Britain, Steadman Jones argues that years of exposure to the decaying urban environment gave rise to a degenerate populace unfit to reach maturity and reproduce its kind. ${ }^{52}$ Indeed, images of social pathology, poverty and deviance in the Empire were linked with theories of urban degeneracy. In addition, the rural location of the rehabilitation institution could well have been a way to break urban delinquency networks. Exposing urban juveniles to an alien country environment would bring them out of their rut of misdemeanour. In this respect, the rural location of the new institution was believed to have a therapeutic effect for juvenile rehabilitation.

Practical subjects were a particular focus at St Pancras because 'the boys ... expressed a loathing for school and they required much patience in teaching, ${ }^{53}$ Secondary education was thrown out of the window and agriculture was a prime subject. In 1938, the institution purchased 14 cows and one bull at a cost of $\mathcal{E} 111$, and pig runs were constructed with a view to teaching animal husbandry. ${ }^{54}$ Inmates were also engaged in chicken projects and a dozen animal books were purchased for the library. ${ }^{55}$ In addition, some 25 acres of land were put under the plough for the production of maize, potatoes, beans, corn, cowpeas and sweet potatoes. When T.W. Stead from Natal was appointed as School Master in 1938, the Superintendent at St Pancras wrote, 'He is enthusiastic and reliable and the right man for the job. With his influence, there will be an added emphasis on physical fitness and the practical side of Agriculture' ${ }^{56}$ There was a deliberate effort to hire people with experience in South African reformatory work as South Africa had a longer history of juvenile delinquency and Industrial Schools. In this respect, the Superintendent's enthusiasm about the new appointment indicated the core values of the government programme at St Pancras. The fostering of a 'rural-mindedness' in white youths was a central rehabilitation objective.

However, state efforts were frustrated because the project at St Pancras remained small, drawing no more than a dozen boys for each calendar year. As an industrial school, the institution was also an overall failure because not a single graduate of St Pancras made it into farming. It was equally a failure as a 
reformatory. William Laurent (17) became troublesome and authorities at the institution labelled him an 'evil influence' and danger to others only a year into his four-year committal period at St Pancras. 'Willie' was found in possession of stolen goods including an automatic firearm. In addition, he had sold stolen clothes to Africans on the school premises and attempted to poison the Superintendent with cattle dip. He also bullied and cheated other inmates at games. At their wits' end, the St Pancras Committee and administration sent the boy home to be supervised by his parents until such a time when the Ministry of Internal Affairs found an alternative for him. ${ }^{57}$ William epitomised the colossal failure that St Pancras was in achieving character reform and instilling industrial training in delinquent youths from "degenerate" homes. By 1939, the institution had acquired a bad name for financial mismanagement, low numbers of inmates, and an increasingly negative public opinion, so much so that magistrates were reluctant to commit juveniles, forcing the government to close it down in 1940.

The collapse of the agricultural training at St Pancras reflected the general sentiment in the colony. When the depression began to bite and youth unemployment rose, captains of industry also pinned delinquency and the youth labour crisis on the character of the Rhodesian lad. Appraising the character and stamina of Rhodesian youth as a candidate for employment, Captain W.H. Kimpton of the Motor Traders' Association, described the average youth as 'indolent and imputed, without initiative or ambition', faults he ascribed to 'lack of parental control, poor physique and undue native assistance'. ${ }^{58}$ Although A.J. Somerville, representing Principals of Salisbury Schools, vehemently disagreed with this view, it was endorsed by the representative of the Salisbury Municipality, M.E. Cleveland, who perceived the youths as 'lacking manners' ${ }^{59}$ The Rhodesia Agricultural Union (RAU) also alleged that the 1930s labour shortages were, to some degree, artificial and expressed disappointment at the fact that offers of permanent employment on tobacco farms at $£, 10$ per month with lodgings had been turned down by white youths on the ground that 'this was no suitable reward for the sacrifice of the attraction of town life which it entailed'. ${ }^{60}$ Similarly, Salisbury and Bulawayo experienced difficulty in getting youths to accept work on the mines. ${ }^{61}$ In view of this fact, white youth were ill equipped and unwilling to respond to the demands of the changing colonial economy and the business community did not have confidence in them.

Government officials were also concerned about unemployed youths who drifted into government relief works in road construction and in European Labour Afforestation Operations (ELAO) in Mtao and Stapleford. ${ }^{62}$ In 1934, there were 59 youths of 21 years of age and under at the relief camps. ${ }^{63}$ The basic daily rate of pay in these camps was $3 \mathrm{~s} .6 \mathrm{~d}$., with efficiency pay at $6 \mathrm{~d}$. and $1 \mathrm{~d}$. per day as bonus. ${ }^{64}$ Some made up to $6 \mathrm{~s} .9 \mathrm{~d}$. per day against the cost of meals, which ranged between $1 \mathrm{~s} .6 \mathrm{~d}$. and $1 \mathrm{~s} .9 \mathrm{~d} .{ }^{65}$ However, the government did not consider the money paid in relief works as a wage but a token given to enable the men to maintain themselves. Barring the social stigma associated with being in a Relief Camp, relief works were an attractive option for 
youths who did not have any family to support. However, officials viewed the youths who were unwilling to take up proper jobs for relief work as running the risk of developing a dependency on the state. For example, a young man under 20 years at Stapleford refused an offer of employment at 5 pounds a month and 'all round', and another left work at 10 pounds per month, plus a free servant, vegetables and fruit, as he 'preferred the life' at Stapleford. ${ }^{66}$ This was exacerbated by the fact that some men were pulling their children, some as young as 16 years of age, from school to join them in relief work to supplement family income. ${ }^{67}$ At Umvuma School, it became a habit for youths to leave school and wait until they were old enough to enter relief camps for adult unemployed whites. Such youths could never be relied upon to sustain an industrious life, become breadwinners and maintain family. Relief schemes, therefore, caused idleness and bred indolence. The commissioner of labour lamented that;

It is highly undesirable that a youth, during his most impressionable years, should be permitted to do relief work. . . Quite apart from the influences with which they are brought into contact, the very nature of the work itself makes it undesirable for the uninformed character, offering as it does but little scope....A more important aspect is that the youth is guided into that frame of mind which makes the acceptance of relief work or charity not distasteful. $^{68}$

This calibre of youth, the commissioner claimed, would most certainly grow up to become a poor white. Indeed, the ELAO at Mtao had been established in 1925 to absorb 'unemployables' - a term referring to those who could not keep employment, apparently due to alcoholism, nomadic habits, and inadequate training - and acted as a temporary relief for those men who were unemployed at the time.

One could argue that white youths wanted something very different from the vision of white masculinity which their leaders considered so critical. Being willing to stay in relief camps with a day wage suggests an affinity for a homosocial fraternal environment rather than the white male paternalistic domestic farm head, or even the working-class father. Young 'delinquent' men wanted what elite white men feared. The failure of St Pancras in engineering a youth with 'rural-mindedness' reflected wider state failures at making this model work. The attempted youth settlement scheme would further reveal the limits of the state paternalism over white youths.

\section{Still birth: Rhodesian youth land settlement scheme, 1934-1952}

The government proposed to introduce a youth settlement scheme in 1934 at a time when farmers were the most affected of all occupations. The objectives of the scheme were the provision of an outlet for youths leaving school and 
securing a larger white population on the land. Opponents of the scheme questioned the logic of trying to attract the youth to farming under such difficult circumstances. However, the Agriculture Department insisted that the scheme was designed to nurture the future class of farmers. Rhodesian-born youths (21-25 years), with some form of agricultural training, or those resident in the colony for not less than five years, were eligible for settlement on Crown Land subdivisions, preferably in the Mashonaland Watershed. The farm sizes were pegged at 500-1,000 acres and the settlers would be mandated to adopt mixed farming; dairying, pigs, poultry and general crops. In addition, every farm had to have small fenced paddocks and close rotational grazing of the pastures. These lands would be leased free of rent for a period and those who proved suitable would acquire the land. The Agriculture Department would make advances of up to $\mathcal{E} 400$ for the construction of small buildings, water supplies, dip tanks and stumping of land. These loans would be free of interest and terms of payment would be relatively easy. The Agriculture Department compelled these young farmers to live frugally and would not permit them to get into debt except to the Lands Department and the Land Bank. ${ }^{69}$

The programme targeted lower-class urban whites and children from farming communities who the state felt did not need a high education for non-existent white-collar jobs. However, state ideas were not in harmony with white attitudes towards agriculture as a career path. The white youths' loathing of manual work was sufficiently captured in the common adage "Digging and hoeing are the privilege of "Jim" and "Sixpence" and white boys are not to be degraded by such work'.$^{70}$ Both the youths and their parents had a prejudice against manual occupations which they viewed as 'kaffir work' (manual labour usually done by Africans). Following the collapse of Matopos Farm School in 1927, Hillside Experimental Station closed down by mid-1930 due to high operational costs and very low numbers of youth trainees. ${ }^{71}$ Ironically, Hillside closed at a time when the state gospel of rural-mindedness was reaching a crescendo. It was difficult for the state to encourage youths to take farming as a career because in the 1930s agriculture was one of the worst hit economic sectors. ${ }^{72}$

The settlement programme suffered a lack of funding and low uptake. In 1935, the Land Bank flatly refused to fund the programme highlighting the depressed prospects in the agricultural sector and instead urged the Agricultural Department to concentrate on making the sector more attractive to young Rhodesians for job prospects. ${ }^{73}$ Meanwhile, the number of youths willing to work on farms continued to dwindle. In 1934 the total number of youths placed with farmers was 26, and by 1935 only four of these remained in agricultural employment. Of the remaining 22 , nine reportedly gave satisfactory service to their employers during their employment varying from nine to 12 months; and ten were discharged as unsatisfactory or left their employers dissatisfied with the conditions. There were clear indications in the mid-1930s that there was neither the money nor the appetite for the land settlement programme to take off. The overarching government policy to train and settle young Rhodesians on the land as part of cushioning them from the vagaries of unemployment and 
as a way to increase white settlement on land did not resonate with a society struggling with the loss of its traditional job markets in the civil service, industry and commerce. Even youths from farming communities aspired to get jobs in the urban areas.

The policy of economic nationalism or 'Rhodesia for Rhodesians' which had gained some momentum in the civil services and sectors of industry where Africans were replaced by white teenagers, was failing in agriculture and land settlement. ${ }^{74}$ Indeed, the Rhodesian economy was dependent upon agricultural prosperity and elites in government preferred to have young Rhodesians take up careers in agriculture and become farmers, but with little success. In 1937 the colonial state relaunched an incentivised scheme for the settlement of young white male Rhodesians on farms to commence in $1938 .^{75}$ The new scheme was supposed to be limited to ten settlers who would have completed a two to three-year agricultural training in up-to-date and efficient methods applicable to the colony. The government anticipated that these youths would be settled on private land donated for this purpose and only the successful ones from the trials would get Crown Land, the loan payment period was stretched to 15 years and again the Land Bank was unwilling to fund the scheme. ${ }^{76}$ When the war broke out in 1939 not a single youth had been settled under the scheme. ${ }^{77}$ A good number of unemployed youths and 'delinquents' were enlisted into the Rhodesian army under the 1926 Defence Act. After WWII the land settlement scheme suffered another false start in 1949 and eventually in 1952 there were ten eligible youths, but no land. Much of it had been taken up by the post-war Ex-Servicemen land settlement scheme.

\section{Conclusion}

Through extensive and ambitious social engineering initiatives for the white settler family, the state in Southern Rhodesia tried to redraw the moral boundaries of an ossified white community. Colonial officials articulated an aggressive state paternalism that sought to intervene in the white family and usurp parental authority. New laws allowed the state to transfer legal guardianship of children to the state and the state also arrogated to itself the right to determine the kind of education suitable for the different classes of white children without seeking parental consent. New educational policies, juvenile rehabilitation institutions and other juvenile facilities became instruments of state social engineering which cultivated the values deemed appropriate by the state. Overall, this chapter points readers to Southern Rhodesia's efforts at manufacturing an ideal white society. However, by acting as "parent" for certain groups of whites in colonial society, the state exposed the limits of the colonial discourse of white supremacy. The fulcrum of white minority rule was the perceived white superiority and by shepherding some whites to maintain white expectation, the Rhodesian state was subverting its own legitimising ideology; not all whites were superior or autonomous. Sections of white society had to be hand-held to toe the line in order to preserve colonial racial and social order. 
Colonial social policy designed to homogenise white society had some unintended consequences.

Racial hierarchy and privilege were not simple products of colonial conquest, but were expanded through arduous work by politicians and bureaucrats to protect and expand them. Performance of power became an everyday thing aimed at galvanising both the coloniser and subject to accept the structure of colonial society. This chapter also speaks to debates about the extent of colonial states' intervention in the lives of not only the colonised but also the white communities. The forced removal of children from indigenous families in Australia and Canada is well documented. However, the colony of Southern Rhodesia used a similar model to take legal guardianship from "failed" white parents into its custody. The overarching state goal to reproduce white supremacy for successive generations made it imperative to pursue paternalistic policies and directly determine the future of white children. The state determined that the future (children) of Southern Rhodesia could not be left in the hands of individual parents but rested with the central authority of the state. The Rhodesian case presents one of those exceptional cases in colonial societies where such a model was used to control the children of the white race.

\section{Notes}

1 Paisley, 'Childhood and Race', 240-259.

2 Olsen, 'Adolescent Empire', 19-41.

3 Southern Rhodesia, Children's Protection and Adoption Act (1929).

4 Olsen, 'Towards the Modern Man', 159.

5 Brownell, The Collapse of Rhodesia, 3.

6 Law, Gendering the Settler State.

7 Hancock and Godwin, Rhodesians Never Die, 11.

8 Mlambo, White Immigration into Rhodesia, 12.

9 Belich, 'The Rise of the Anglo World', 53. See also Belich, Replenishing the Earth.

10 Southern Rhodesia Ordinance No. 19 of 1904.

11 On Rhodesian Immigration Policy see Mlambo, White Immigration into Rhodesia.

12 Kirkwood, 'Settler Wives in Southern Rhodesia', 147.

13 Kufakurinani, 'White Women and Domesticity in Colonial Zimbabwe', 144.

14 Bush, 'Gender and Empire', 77-111.

15 Tawse-Jollie, The Real Rhodesia, 229.

16 Ibid., 230, 232.

17 Education Committee, Southern Rhodesia Education Committee Report 1908 (Salisbury, Argus: 1908), 4.

18 Southern Rhodesia Education Ordinance No. 1 of 1903.

19 National Archives of Zimbabwe (hereafter NAZ), SRG 3, Legislative Council Debates, 1907.

20 Gann and Gelfand, Huggins of Rhodesia, 136.

21 Phimister, An Economic and Social History of Zimbabwe, 171-172.

22 Government of Southern Rhodesia, Report on the Unemployment and the Relief of Destitution in Southern Rhodesia (n.p., 1934), 4.

23 Ibid., 5.

24 NAZ, S824/42/2, Government of Southern Rhodesia, Juvenile Affairs Boards, 19321934; Director of Education, Southern Rhodesia to the Secretary, Department of the Colonial Secretary, 3 February 1932. 
25 Summers, 'Boys, Brats and Education', 132-153.

26 Olsen, 'Adolescent Empire', 20.

27 NAZ, S824/42/2, Government of Southern Rhodesia, Juvenile Affairs Boards, 19321934; Director of Education, Southern Rhodesia to the Secretary, Department of the Colonial Secretary, 3 February 1932.

28 Ibid.

29 Government of Southern Rhodesia, Report on Unemployment, 8.

30 Ibid.

31 Southern Rhodesia, Southern Rhodesia Legislative Assembly Debates. Volume 7, 849.

32 Government of Southern Rhodesia, Report on Unemployment, 10.

33 Ibid.

34 Paisley, 'Childhood and Race', 240-241.

35 NAZ, SRG 3, Southern Rhodesia Legislative Council Debates, 9 August 1915, Column 198.

36 NAZ, S824/345/1, Education: European, Asian and Coloured Division: Industrial Schools, 1931-1934, Director of Education to all Magistrates, Circular, 3 July 1931.

37 Government of Southern Rhodesia, Report on Juvenile Delinquency in Southern Rhodesia, December 1935 (n.p., 1935), 1.

38 NAZ, S824/345/1, Education: European, Asian and Coloured Division: Industrial Schools, 20 July 1931-1 February 1934; Inspector of Schools, Bulawayo, to Director of Education, 17 March 1932.

39 Dubow, 'Race, Civilisation and Culture', 5-8.

40 NAZ, S824/345/1, Institutions for Juvenile Delinquents, 20 July 1931-1 February 1934, CID Detective Sergeant, Que Que, to Assistant Magistrate, Que Que, 1 October 1931.

41 NAZ, S824/345/1, Institutions for Juvenile Delinquents, 20 July 1931-1 February 1934, Sergeant, Bulawayo Police Station to Chief Superintendent CID, 16 October 1933.

42 Ibid.

43 Children's Protection and Adoption Act (1929).

44 NAZ, S824/345/1, Institutions for Juvenile Delinquents, 20 July 1931-1 February 1934, Assistant Magistrate Chipinga to the Director of Education, Salisbury, 28 July 1932.

45 Ibid.

46 Children's Protection and Adoption Act (1929).

47 NAZ, S824/346/1, Destitute European and Coloured Children Maintained at Institutions, 1936.

48 Summers, 'Boys, Brats and Education', 132-133.

49 Olsen, 'Adolescent Empire', 20.

50 The Industrial Conciliation Act of 1934 was the key legislation designed to impede African social mobility on the job market. It reserved industrial apprenticeship for whites and removed Africans from the definition of 'employee'.

51 Chisholm, 'Reformatories and Industrial Schools in South Africa', 92.

52 Stedman Jones, Outcast London, 285.

53 NAZ, S824/345/3, Institutions for Juvenile Delinquents, 1937-1939; St Pancras Superintendent report for the period 1 July 1936-31 September 1937, 3.

54 NAZ, S824/345/3, Institutions for Juvenile Delinquents, 1937-1939; Minutes of Meeting of the St Pancras Home Committee Held at Southern Life Offices, 7 October 1938, 1.

55 NAZ, S824/345/3, Institutions for Juvenile Delinquents, 1937-1939; St. Pancras Superintendent, PC Sykes report to the St Pancras Home Committee, 19 May 1938, 1.

56 NAZ, S824/345/3, Institutions for Juvenile Delinquents, 1937-1939; St. Pancras Superintendent's report to the St Pancras Home Committee, 18 May 1938, 1.

57 Ibid.

58 NAZ, S824/42/2, Government of Southern Rhodesia Juvenile Affairs Boards, 19321934: Minutes of the Inaugural Meeting for the formation of a Juvenile Affairs Board, Salisbury, 4 March 1932, 12.

59 Ibid., 13.

60 Ibid. 
61 Government of Southern Rhodesia, Report on Unemployment, 9.

62 Ibid.

63 Ibid., 11.

64 NAZ, S1194/1660/1, Government of Southern Rhodesia, White Labour Afforestation Camp: Mtao Report, Memorandum from Minister of Agriculture to the Department of the Colonial Secretary, 10 December 1930, 1.

65 Ibid., 2.

66 Government of Southern Rhodesia, Report on Unemployment, 16.

67 Ibid., 18.

68 Government of Southern Rhodesia, Report on Unemployment, Extract from Education Commission, Report of the Education Commission, 1929 (Cape Town: Cape Times, 1929).

69 NAZ, S1194/190/23, Settlement of Young Rhodesians on the Land, 1937-1952.

70 NAZ, S1194/198/1, Farm Training for Youths at Mtao and Stapleford: Report of Committee on Unemployment, Relief and Destitution in Southern Rhodesia 1934, 7.

71 NAZ, S1194/190/23, Settlement of Young Rhodesians on the Land, 1937-1952.

72 Ibid.

73 Ibid., Land and Agricultural Bank to Secretary Department of Agriculture and Lands, $15 / 01 / 35$.

74 Machingaidze, 'The Development of Settler Capitalist Agriculture', 255.

75 S1194/190/23, Settlement of Young Rhodesians on the Land, 1937-1952.

76 Ibid.

77 There is a yawning gap in the material on the youth settlement scheme between 1939 and 1949. 


\title{
3 Immigration and settlement of "undesirable" whites in Southern Rhodesia, c. $1940 \mathrm{~s}-1960 \mathrm{~s}$
}

\author{
George Bishi
}

\section{Introduction}

This chapter focuses on the immigration and settlement of so-called undesirable white immigrants in Southern Rhodesia, or simply Rhodesia, in the 1940s to the 1960s. In the post-Second World War years, Rhodesia embarked on a massive immigration campaign to attract more British settlers to increase the white population for economic, social and political reasons. This chapter argues that besides the exploitation of Africans, racism and restrictive immigration policies, notions of white undesirability troubled the Rhodesian settler community during this period. This chapter seeks to demonstrate that white undesirability was a contested, fluid and ambiguous concept influenced by political, social and economic circumstances prevailing at the time. Rhodesian settler communities often conflated race, class and culture to classify other white groups as undesirable despite their strong economic position and white skins. It relied on assumptions and stereotypes directed towards other immigrants officially known as white aliens, mainly Italians, Greeks and Portuguese considered to be economically "poor". In the post-war years, Rhodesian officials expressed dismay at the quality and type of British immigrants the country received. Later in the 1950s, the country received non-British immigrants and deported some of them as undesirable characters because of their class, moral conduct and criminal records.

Rhodesian settlers fashioned undesirability against its perceived settler standards - white respectability, moral purity and acceptable behaviour, and high wages, amongst other colonial rhetoric virtues. Curiously, instead of fashioning white undesirability against Africans, Rhodesian settlers crafted it against the so-called desirable whites. As this chapter will show, Rhodesian immigration officials had powers to define, according to the law and opinion, the desirability and undesirability of white immigrants. This chapter deals with social histories of undesirable whites and introduces human stories at the expense of laws and policies. It shows that although whiteness was a rallying point for the Rhodesian settlers, there were some divisions and tensions within the white community based on class, ethnicity, culture and political aspects. Despite the existence of these divisions, in a racialised society such as Rhodesia, whites certainly enjoyed colonial privileges and power compared to Africans. Rhodesian 
settlers would consider it a disgrace if new white immigrants had similar living standards to Africans.

\section{Desirable and undesirable white immigrants, whiteness and Britishness in Rhodesia}

Immediately after the war, the Southern Rhodesian government embarked on a massive drive to attract white settlers of the "right type", mainly from Britain. Generally, the right type meant white immigrants from Britain and English-speaking South Africans with capital, acceptable moral and political views, sound health, and with no criminal records, amongst other requirements. Section 3(d) of the Southern Rhodesian immigration regulation provided a definition of the legal immigrants which the country was willing to either accept or deny entrance to. Rhodesian immigration officials and the governor had the power to classify immigrants as desirable and undesirable after receiving positive or suspicious information from any foreign government or through diplomatic channels. ${ }^{1}$ Immigration officers were supposed to issue a written statement to immigrants either granting or denying entry or asking them to leave the country as undesirable. If immigrants were deemed undesirable, they had the right to appeal to the nearest magistrate court within three days after receiving a notice of deportation. ${ }^{2}$ Evidently, besides the provisions of the law, immigration officials played a significant part in defining the desirability and undesirability of immigrants depending on circumstances.

The issue of white population stability remained centrally important to settler politics throughout the colonial period and immigration remained the main way of increasing the white population. ${ }^{3}$ However, Rhodesian immigration policies were selective, restrictive and less accommodating, especially to those immigrants who were not of British cultural extraction. ${ }^{4}$ Ethnic chauvinism reflected itself in the immigration policies of Southern Rhodesia at least before the 1960s. This factor, amongst others, discouraged large-scale white immigration into Rhodesia especially from 1890 up to the 1940s, despite the officials' desire to create a "white man's country". ${ }^{5}$ After the Rhodesian Front government unilaterally declared independence (UDI) from Britain in 1965, white migration and demographic patterns took a different twist and scholarly attention has focused on this period. ${ }^{6}$ For example, Peter Godwin and Ian Hancock discuss the impact of the war on white politics in the 1970s and the contradictions whites encountered in trying to defend what they called the "Rhodesian way of life". 7 In his study of the final days of white Rhodesia, Josiah Brownell argues that the state capitulated primarily because it lost the battle of numbers to stand against Africans. ${ }^{8}$ The selectivity of Southern Rhodesian immigration regulations was not unique. In the 1940s, Canada, Australia and New Zealand were not willing to allow entry to whites of perceived poor quality. ${ }^{9}$ While the literature on Rhodesia discuss patterns of white migration and the selective nature of immigration policies, it assumes that only the socalled desirable whites settled in the country. 
One striking feature of the Rhodesian settler community was its Britishness, a situation that remained dominant up until the late 1950 s. ${ }^{10}$ Rhodesian settlers appropriated the sense of Britishness to distinguish themselves from the Afrikaner-dominated South Africa. The state preferred settlers of British origin who could develop the country and be good citizens and this explains Rhodesians' desire to create a British fragment north of the Limpopo River. For white Rhodesians, the inclusion of non-British "types" would create, in effect, an entirely new fragment in Rhodesia, but one which was not entirely British. ${ }^{11}$ Frank Clements reveals that in white Rhodesian society, 'status depended more on origin than on class or education. Where a man's father came from mattered more than anything else'. ${ }^{12}$ Unsurprisingly, as John Parker observes, 'Rhodesia remained in many ways the most British of all the colonies' ${ }^{13}$ The influence of civil servants and the jingoism of Rhodes, the founder of the colony, were instrumental in propping up this ultra-British flare making Rhodesia 'more English than the English'. ${ }^{14}$ Therefore, in the years before the turbulent 1960s, non-English speaking whites occupied a second class position within the Southern Rhodesian settler community.

Rhodesian whites created an image of a thriving settler community presiding over the African majority. One of the reasons for screening immigrants was to avoid "poor white aliens" entering the colony. ${ }^{15}$ Rhodesian settlers considered whites who lived below their expected standards as deviants and undesirable, or they were simply known as the "other". This was different from the early Rhodesian settler self-image fashioned in relation to Africans, the imperial homeland of Britain and white South Africans. ${ }^{16}$ This is different from Linda Colley's argument that common threats, real or imagined fears, or interests united British people in the Dominions and settler colonies acting as points of convergence at different times. Colley postulates that 'whatever their own differences, Britons could feel united in dominion over, and in distinction from, the millions of colonial subjects beyond their own boundaries'. ${ }^{17}$ In South Africa, John Lambert observed that British whites constructed their identities in relation to Afrikaners and Africans. ${ }^{18}$ In an ambivalent scenario, Rhodesian settlers not only fashioned their identities against Africans but also in relation to desirable whites. However, the definition of undesirability was fluid depending on the prevailing circumstances, especially in the post-war years when the state judged other white immigrants as undesirable. As a result, the definition of desirability and undesirability depended on political, social and economic factors. The government granted resident permits to some whites who initially entered the country as desirable, but later these same whites came to be regarded as undesirable.

\section{Post-war white immigration, assimilation and "Poor White Trash"}

During the Second World War, there was a drop in white immigration as overseas travelling was difficult and the Rhodesian government wanted to keep jobs open for the demobilised white soldiers. As part of its war effort for the British 
Empire, Southern Rhodesia hosted over 12,000 German, Austrian and Italian internees as well as Polish refugees. ${ }^{19}$ Deliberations were made after the war to accept Italians who made applications to stay in the country provided they had employment and were "of good character", in order for them to be assimilated into the settler community. ${ }^{20}$ Immigration officials placed emphasis on their moral conduct to ascertain whether their desirability was compatible with established settler standards. However, many internees of different nationalities and Polish refugees chose not to remain in the country after the war. Even so, after the war, white immigration increased as hundreds of demobilised British soldiers entered the country under the Rhodesian land settlement scheme to attract British and Royal Air Force (RAF) ex-servicemen and their families. ${ }^{21}$ The UK provided free passage into Rhodesia for a limited number of suitable British ex-servicemen and women together with their dependants. ${ }^{22}$ Rhodesia wanted white immigrants with a certain amount of income who had friends in Rhodesia who were already involved in farming. ${ }^{23}$ The government expected immigrants to possess a sum of money and/or property exceeding $\ldots 50$, a further sum exceeding $£, 10$ for each dependent they brought with them, and bona fide employment for a period of not less than six months. ${ }^{24}$ Arguably, few whites could meet these criteria and this provision deliberately excluded a large number of prospective immigrants.

The Selection Immigration Board was responsible for selecting suitable and desirable white immigrants with almost complete autonomy. Some members of the government made up the Board and worked closely with other departments for consultation in unclear circumstances, but it had the final decision. During the war, refugees without income were a source of concern to the Board. The Board noted that Jewish refugees and non-English speaking whites who entered the colony during the pre-1940 period were keen to bring in their relatives of varying degrees of kinship without the necessary means or qualifications to earn a living. ${ }^{25}$ However, their relatives in Rhodesia attempted to overcome this setback by giving promises of maintenance. For fortuitous reasons, such promises were of no effect before the law and repudiated in the event of death or a change of mind by the local sponsor, leaving the applicant to charity. ${ }^{26}$ The Board did not regard these applicants as useful and desirable citizens. It considered that accepting such cases would lead to organised immigration of non-English speaking whites to the probable prejudice of ex-service and other British immigrants. ${ }^{27}$ The Board confined their acceptance to compassionate cases involving wives, children under sixteen and aged parents or grandparents. In this case, class played a crucial role in determining the undesirability of these white groups. The Appeal Board made their selections on the basis of personal opinion and not on law, in deciding on the desirability and undesirability of immigrants. Therefore, there was a possibility for the Selection Board to refuse individual applications made on identical grounds. For instance, the Appeal Board could decide to admit the unqualified whites on compassionate grounds or could refuse the application. ${ }^{28}$ Even if repeatedly overruled by the Appeal Board the Selection Board would adhere to its view and continue to reject 
applications of this type, thus exposing the contradictions within the immigration policies of the country.

The state was unable to fulfil its intended ambition of attracting large numbers of whites and to assimilate them into the Rhodesian settler community. Authorities doubted the feasibility of simultaneously bringing large numbers of whites to Rhodesia and assimilating them with the ideas and habits of the country. ${ }^{29}$ As Shutt notes, new immigrants flocking into the country after the war were to be educated in the nature of white Rhodesian culture and manners by older settlers. ${ }^{30}$ Considering the racial nature of Rhodesia, it was difficult for the old settlers to integrate large volumes of new immigrants holding liberal views. However, some immigrants were officers leaving newly independent India who found Rhodesia to be the best place for them because they believed in white supremacy. ${ }^{31}$ There were also adventurous immigrants from South Africa who were perturbed by assertive Afrikaner nationalism and the election victory of the National Party. By the late 1940s it became apparent that the influx of immigrants was greater than the country could possibly absorb. ${ }^{32}$ To deal with this challenge, the government introduced immigration restrictions to manageable proportions by compelling employers to give a guarantee for the repatriation expenses of immigrants introduced into the country. This regulation encouraged employers to engage immigrants from other territories in Southern Africa rather than the UK. ${ }^{33}$ This incentivised employers to hire migrants from so-called undesirable white groups in South Africa and Mozambique. The government introduced a flat rate of immigration guarantees, irrespective of whether an employer brings the immigrant from Southern Africa or from the UK. By 1950 the government had relaxed the immigration regulations into the country. After two years, the government returned financial deposit guarantees to employers on behalf of British immigrants.

When the Federation of Southern Rhodesia, Northern Rhodesia and Nyasaland came into being (1953-1963), aspects of the desirability of white immigrants remained topical. Rhodesian settlers flaunted the idea of maintaining the ambiguous British way of life in the Federation. Southern Rhodesia attracted more white immigrants because it was the most economically developed territory in the Federation. The 1954 Immigration Act and the Immigration Regulations governed the selection of immigrants into the Federation. The Federal government took over the responsibility of immigration from the three territorial authorities placed under the Ministry of Home Affairs based in Salisbury, Rhodesia's capital and the Federal capital. The government's immigration policy was to bring into the Federation the greatest number of suitable immigrants that the country could absorb in order to develop the country's natural resources. ${ }^{34}$ There were two selection boards: one in Salisbury and the other at Rhodesia House in Britain, which considered applications for permanent residence in the Federation from British subjects. According to immigration regulations, immigrants were supposed to get residence permits before entering the Federation. The London board considered applications for permits 
only from British subjects who at the date of application were resident in the UK or the Republic of Ireland. The Salisbury board considered applications for residence permits in the case of all other British subjects.

In considering applications for residence permits, the boards followed the procedure set out in the immigration Act and Regulations. The boards were to be fully satisfied that the desirable immigrants were of good character, sound physical and mental health, that they had sufficient means to pay for their maintenance, and were in possession of sufficient capital. ${ }^{35}$ The boards could refuse residence permits to any applicant likely to pursue occupations already congested in the Federation. They also considered the productivity, suitability and efficiency of qualified immigrants before granting them residence permits. ${ }^{36}$ The Federal board could refuse to issue residence permits to aliens if not satisfied that such whites were likely to become desirable inhabitants or were harmful to the welfare of the Federation within a reasonable period after entry. ${ }^{37}$ Authorities expected immigrants who applied to stay in Rhodesia to have knowledge of the English language. This was in line with the national language policy and helped to preserve the Britishness of Rhodesia.

Rhodesian settlers expressed mixed perceptions towards some of the postwar British immigrants. Some well-placed Rhodesian officials, such as Alan D. Hutchison Lloyd, claimed that a greater proportion of the post-war immigrants belonged to the lower class. Lloyd joined the Education Department in 1933, transferred to the Department of Justice, and later became a member of Garfield Todd's short-lived Cabinet. Lloyd averred that after the war, British immigrants were of the poor type endeavouring to get away from the austere post-war conditions in Britain. ${ }^{38}$ Old settlers expressed unsympathetic attitudes towards the class of new immigrants whom they accused of diluting the racial boundaries of Rhodesia. Lloyd recalls a revealing incident that sheds light on how other non-Rhodesian whites expressed similar disgust at the class of the post-war immigrants:

I remember well going down for an appeal by air to Bloemfontein in the Union of South Africa. I was sitting next to a man who told me he was a Director of the Hong Kong and Shanghai Bank and lived many years in Ceylon, who, knowing I was a Rhodesian, said to me that he was surprised at the amount of the poor white trash that he saw in Bulawayo. ${ }^{39}$

Evidently, in this quotation, Lloyd was eager to express his status and position because he could fly to South Africa and meet top officials. The idea of calling new British immigrants trash is quite revealing of how class and poverty were important in defining undesirability. It also reveals that even British immigrants, despite being of the officially accepted cultural group, could be considered undesirable if they were not sufficiently wealthy. Moreover, some new British immigrants freely mixed with Africans, transcending racial boundaries. Ralph Drew Palmer, who came to Rhodesia in the 1920s, 
alleged that it was the nature of post-war immigrants that changed the political landscape of the colony:

They used to go and have tea in the kitchen, and speak to [Africans], as they would do to another European, and eventually the African would let them down - he would pinch all the sugar or go away and not come back on the time he said he would. Moreover, all these sort of things would upset these chaps and they immediately went over to the right wing. It is one of the reasons for a sudden political change and feeling in the country; it was a result of the new immigrants. ${ }^{40}$

This kind of racial indifference angered the older settlers who considered themselves as heirs to the so-called Rhodesian way of life and guardians of the pioneering and imperial tradition in the country. Old Rhodesians cynically directed their intolerance to new immigrants as the scapegoats for political and economic pressures in the country.

Rhodesian settlers were not comfortable in welcoming immigrants holding different political views, and grew progressively more hostile to anything they believed to be communism after the Second World War. The example of Charles Taylor is a clear testimony where authorities used political justification to conceal deep-seated labour problems in the country. Taylor, a recent migrant from Britain, was a key figure in the 1954 Rhodesian railways strike over poor salaries. He had previously been a member of the National Union of Mineworkers in the UK. Rhodesian immigration officials deported Taylor for leading the strike and most importantly because of his communist connection in Britain. ${ }^{41}$ Taylor's wife claimed that her husband ceased to be a card-carrying member of the Communist Party before he left for Rhodesia and, upon entering Rhodesia, had denied that her husband had any connection with the Communist Party in Britain. ${ }^{42}$ Garfield Todd, the prime minister of Southern Rhodesia, alleged that his administration deported Taylor because his wife said that he had been a member of the Communist Party in Britain but he lied to immigration authorities about his connections. ${ }^{43}$ Since Taylor showed great skills in organising a strike, it was essential to find some way of removing him from the scene. ${ }^{44}$ The briefings of the British Security Liaison Officer in Salisbury revealed that Taylor had a communist background and that he maintained his communist connection in the UK until his departure for Southern Rhodesia. $^{45}$

Initially, the government accused Taylor of breaching the Rhodesian Peace Preservation Act by leading the strike. Jack Keller, a Labour member of the Rhodesian Parliament described the Act in cynical terms. He called it 'a barbarous and a measure of the Mussolini and Hitler type. It gave the prime minister power to turn Southern Rhodesia into a police state and should never be tolerated by a British possession'. ${ }^{46}$ Todd admitted that the Act did not target Europeans who should have a strong sense of responsibility. Later, Taylor complained that he did not receive any communication from Rhodesia prior to his 
deportation as a prohibited immigrant. The high commissioner in the Federation of Rhodesia and Nyasaland noted that Taylor had outstanding qualities as a demagogue. ${ }^{47}$ The Rhodesian government considered Taylor a dangerous person to remain in the colony and decided to deport him as an undesirable immigrant. The National Union of Mineworkers protested over the deportation of Taylor from Southern Rhodesia because of a labour dispute and without trial. ${ }^{48}$ However, Taylor did not bother to use the provisions of the legislation to contest his deportation. Taylor alleged that whilst in Rhodesia he did the unmentionable thing of borrowing money from his (African) house-boy to buy milk for his children. ${ }^{49}$ This was unmentionable because Taylor belonged to the broader white society expected to live above the level of Africans.

Some whites became undesirable and were declared prohibited immigrants after the government granted them permits to stay in Rhodesia. For instance, one Watch Tower Movement missionary called Cooke arrived in Rhodesia in January 1948, on a six-month visit permit for work. He was engaged as a full-time missionary and devoted most of his time to Africans. Later in 1948, four more Watch Tower missionaries arrived from Canada for the purpose of full-time employment. The secretary for Native Affairs was of the opinion that the Watch Tower organisation was now more of a nuisance than it being dangerous. ${ }^{50} \mathrm{He}$ also felt that declaring these five Europeans as prohibited immigrants - after allowing them in to the colony for two months - would make martyrs of them. He agreed with the commissioner of police that the sending of missionaries to Rhodesia by the Watch Tower Society was unnecessary and undesirable. ${ }^{51} \mathrm{He}$ therefore suggested that instead of declaring these five people prohibited immigrants, they be given a time limit and told that their temporary permits would not be renewed. The government deliberately refused the renewal of their permits and deported them as prohibited and undesirable characters. However, it was no secret that the state knew about the previous activities of the Watch Tower movements in the country around 1917. These missionaries were whites, English-speaking and possessed qualities that made them desirable in the first place. Their alleged activities amongst Africans shifted their desirable status to become undesirable immigrants.

Some cultural associations such as the District of the Sons of England and Benevolent Society of Rhodesia were deeply concerned with the emergence of divisions within white Rhodesia settler community, supposedly caused by new immigrants. The association originated in Toronto in 1874 before it spread into South Africa in 1881 and later into Rhodesia with its membership restricted to males of British birth or descent, pledging to maintain imperial interests in the subcontinent. ${ }^{52}$ The Lodge complained that non-British immigrants were diluting the British way of life in the country. The Rhodesian settler community was more egalitarian and not entirely reflective of the class-based British life. The minister of Internal Affairs, Hugh Beadle, told the Sons of England about the British foundations of white settler Rhodesia. He alluded that the preservation of the essentiality of the British character of Rhodesia and the reasonable standard of living of whites were two foundations of the country. ${ }^{53}$ 
These ideals seemed axiomatic but there was pressure on the government to introduce measures that might encroach on them. Southern Rhodesian legislators designed the Aliens Act of 1946 as a way of preserving the colony's British background. Beadle assured the Lodge that since 1946 the immigration of aliens had been limited annually to 8 per cent of the number of British immigrations who entered the colony. ${ }^{54}$ Periodic movements for admitting larger numbers of central Europeans and Italian peasants for the colony's economic progress were not sufficient for justifying the dilution of Rhodesian white values. Officials reasoned that the influx of non-British immigrants had the potential of lowering standards of living in the colony. ${ }^{55}$ However, this was an exaggeration: officials conveniently excluded other white immigrants because of their cultural heritage regardless of their socio-economic status.

Rhodesian officials were not willing to accept immigrants looking for jobs, to avoid the problem of unemployed whites. The country needed white immigrants able to start their own private business. The Rhodesian Recorder, a monthly magazine concerned with industrial development in the country, in an exaggerated manner alluded to this fantasy: 'Rhodesia is outstandingly a place where you can get on your own, in preference to getting into a job. People taking risks quite the opposite to the socialistic doctrine of so-called "security" built up the British Empire'. ${ }^{56}$ This comment captures differences between Rhodesia and the post-war British welfare state. The industrial community further advocated for more thrift and entrepreneurial settlers to immigrate into the colony. 'We do not want too many cotton-wool people in Rhodesia. ... We need all talented folk who are thinking of settling here. . . Rhodesia is one of the last bastions of private enterprise' ${ }^{57}$ The idea of attracting only talented whites and framing Rhodesia as the last bastion of private enterprise is telling of the rhetoric of settler pride. Certainly, this was an exaggeration cushioned in settler nationalism and quite opposite of the economic realities in the country. Rhodesian whites prejudiced job seeking immigrants as soft-handed and lazy because it was against the settler projection of a hardworking community. Desirable white immigrants were supposed to bring skills and money to invest in the country or establish branches in Rhodesia from overcrowded British industries. ${ }^{58}$ The idea was that this type of white immigrant would lead to the economic development of the country. White immigrants who could not take care of themselves were undesirable as they had the potential to offset established white standards within the Rhodesian settler community.

\section{Immigration of other "undesirable" whites}

During the Federation years, Salisbury, the Federal capital, attracted the most immigrants including the so-called undesirable white immigrants because it offered more opportunities. In the 1950s, the largest groups of undesirable alien whites were Italian, Portuguese and Greek. ${ }^{59}$ Soon after the Second World War, Greece was plunged into serious economic challenges leading to the exodus of many people looking for economic opportunities and the country was 
steeped in poverty in the 1960s. ${ }^{60}$ The Federation attracted Italian, Portuguese and Greek immigrants who were seeking economic opportunities. Because they were non-British and were looking for economic opportunities, Federal authorities considered them to be undesirable. Non-British immigrants for the years 1955-56 constituted 12 per cent of the total white immigration, though only 10 per cent were considered to be desirable. ${ }^{61}$ This meant that 2 per cent of the total number of white migrants were non-British undesirable immigrants, which was quite significant and the majority of them chose to settle in Southern Rhodesia.

There were particular worries within the Selection Board over Italians who opened firms and businesses in the Federation and employed their own nationals. ${ }^{62}$ The state wanted to attract investment in the Federation and limit the numbers of the so-called alien immigrants. Interestingly, even if Italians belonged to the wealthy classes, their cultural background made them undesirable. The Board encountered difficulties when non-British firms registered, acquired premises and engaged staff from outside Rhodesia to apply for residence permits. ${ }^{63}$ Officials wanted firms to employ Rhodesian settlers before engaging Italians, Portuguese, Greeks and other white immigrants.

The construction of the Kariba Dam in the 1950s exposed race and class tensions in Southern Rhodesia as the presence of Italians caused uneasiness amongst the pro-British settlers of the colony. The project itself was a source of settler pride because of its size and engineering achievement, seen to demonstrate white civilisation and progress in the region. As Julia Tischler writes, the fact that the Federation awarded an Italian construction firm the tender to construct the Kariba Dam generated much tension in Rhodesia and it was a metropolitan problem. 'It exposed colonial patronage as being incompatible with "free-market" modernisation, probing British motives behind post-war development and contributing to the ideological deconstruction of the Empire'. ${ }^{64}$ Rhodesian whites did not embrace the presence of southern Europeans whom they looked down upon as belonging to inferior cultural heritage. Their white skin and race were not enough to be on equal terms with British and Englishspeaking settlers in the country. Their class made them undesirable despite the fact that they were Europeans and not Africans.

However, it was not only during the construction of the Kariba Dam that race and class tensions were exposed within the white Rhodesian community. Perceptions about Italians continued to surface in racial partnership politics associated with the Federation period in Rhodesia. The overtly British white Rhodesians perceived Italians as "poor" whites. Their presence in the country would therefore dilute the perceived Britishness and moral standards of Rhodesian white society. Some Rhodesians called Italians and Greeks, as the novelist Doris Lessing states, "wops and dagos" or even worse "scum of the earth". ${ }^{65}$ Their white skins were not sufficient as a cultural asset, even when placed in contrast with Africans. Lessing recalls one Rhodesian liberal white saying, 'I do not mind being considered the equal of an educated African, but I object to any dregs from Europe being my equal simply because they have 
white skins' ${ }^{66}$ In this case, undesirability was quite an arbitrary and fluid concept that the state deliberately applied to include and exclude other white categories.

The Rhodesian business community perceived that non-British artisans accepted lower rates which was in direct contrast to established settler standards associated with advanced skills and higher wages. Rhodesian whites questioned the possibility of assimilating Italians who were willing to accept lower standards against the accepted settler status. ${ }^{67}$ There was no legislation restricting the proportion of alien to British employees and firms took advantage of this situation. This led to the formation of clusters of non-British nationals and Rhodesian settlers who felt that this had the potential of diluting and endangering their imagined white standards and the Britishness of Southern Rhodesia. Moreover, the situation disadvantaged British subjects in the country who felt entitled to available job opportunities. Selection Boards could refuse issuing permits to aliens if there were unemployed British white artisans available in the country. ${ }^{68}$ Overall this was not helpful as some alien firms were prepared to do without rather than employ British artisans. In 1958, the Rhodesia chief industrial officer compiled a list of 73 firms giving names of building contractors in Salisbury who employed aliens. Twenty firms employed only alien artisans and the remaining forty employed a mix, although aliens were predominant. ${ }^{69}$ This was in relation to the official desire to populate the country with British setters. In the existing circumstances of poor employment prospects, there were fewer British immigrants willing to migrate to the Federation. In Britain and South Africa, most people in the occupational categories from which the Federation obtained its immigrants enjoyed a high standard of living. ${ }^{70}$ These countries also demanded their services and no one risked being unemployed. As a result, this forced firms to hire cheaper and readily available white artisans.

Another factor worrying officials was that many foreign migrants had left their families behind, especially Italians working on the railways. This brought substantial demand for family reunion that had a great impact on the number of permits issued to aliens and irked officials when some of them used their social networks to bring in their relatives and friends. ${ }^{71}$ After the war, Italy faced economic challenges and hence many Italians abroad saw no reason for going back home. Some had lost contact and roots with home after spending many years in other parts of the world and wanted to stay in Southern Rhodesia or other territories in the Federation. After the promulgation of the Aliens Act in September 1946, by 1949 the Alien Immigrants Selection Board approved 148 applications from Italians. ${ }^{72}$ The Board received a steady stream of applications for permits from Italians living in such places as Egypt, Abyssinia, Eritrea and Somaliland because in these territories colonial rule was ending, triggering political and economic uncertainty.

The Inter-Governmental Committee for European Migration (ICEM) was responsible for bringing most of the undesirable whites into the country employed by the Rhodesian railways. Because of their cultural and national affinities, they tended to stick together in little enclaves because they entered the 
country in batches, infuriating Rhodesian whites concerned with the preservation of a British settler colony. Rhodesian settlers were also a minority mainly made up of immigrants but could not tolerate other white categories because of colonial class, ethnic, political and moral prejudices. In December 1955, the first batch of Greeks employed by the railways faced objection from their British colleagues. ${ }^{73}$ However, this apparently subsided because the numerically smaller and politically weaker Greeks did not retaliate. Rhodesian whites showed initial objection and resentment for working with Greeks because of language difficulties and prejudices related to unhygienic habits. ${ }^{74}$ Rhodesian whites associated whiteness with settler privileges, higher wages, white-collar jobs, hygiene and comfortable living conditions above those of Africans. Tischler argues that in a society founded on immense inequalities between the black majority and the white minority, settlers vehemently defended these privileges. ${ }^{75}$ Rhodesian settlers dominated the African majority using discriminative legislations in all aspects of life. As a result, settlers wanted to protect these colonial privileges and could not tolerate whites who seemed to lower these standards.

The following examples demonstrate that Rhodesian settlers conflated racial boundaries with acceptable moral conduct to ascribe undesirability to nonBritish immigrants. During the Anglo-Rhodesia steel project, the presence of Italian workers disgusted Rhodesian officials. The minister of Interior, Hugh Beadle, declared that an influx of Italians were living almost on the level as Africans. ${ }^{76}$ The Italian ambassador was anxious to dissuade the Rhodesian government from retracting their approval from the scheme to employ Italian labour. The Foreign Office was anxious to see this project progressing well to ease Italy's economic challenges and population problems, thereby diminishing the spread of communism in Italy. It would certainly be unfortunate, to the British Foreign Office officials, to abandon the project purely because of any prejudice against Italians on the part of the Southern Rhodesian government. ${ }^{77}$ The parochialism of Southern Rhodesian settlers towards other whites had the potential of tarnishing British-Italian relations in the post-war years. Identity politics amplified by the classification of other white groups as undesirable had definite political implications. Although it was anxious for the deal to work, the Foreign Office did not want to endanger the general immigration policy of Southern Rhodesia. In similar circumstances, the Rhodesian railways which employed Italian plate layers expected them be able to read, write and speak English in order to be able to understand instructions. ${ }^{78}$ Italians supervised Africans in the railways; therefore, it was mandatory for them to present settler self-image as respectable white masters. The Rhodesian government could not expect the railways to employ Italians holding extreme political views at variance with the democratic principles observed in British territories. ${ }^{79}$ Since they worked with Africans, there were fears that radical or fascist-minded Italians would influence Africans to disrespect authorities and question the settler government.

The proximity of colonial Mozambique in the east allowed for Portuguese artisans and "chancers" to infiltrate into the Federation looking for employment. ${ }^{80}$ By calling Portuguese artisans "chancers", Rhodesian settlers perceived 
these immigrants to be of poor class by their white standards. This resulted in many Portuguese entering the building industry and competing with white British artisans. Since Portuguese artisans looked for cheap employment, this was an aberration to established white views. Industrial officials complained about the alleged conduct and indecent behaviour of Portuguese workers considered inappropriate with regards to perceived white moral purity. Because of their numbers, Portuguese immigrants formed their own communities, which made assimilation impossible. Officials noted that their social contacts were Asians, coloured and African prostitutes, shebeens (unlicensed drinking establishments) and that they generally lived in squalid conditions and standards lower than that of Africans. ${ }^{81}$ In colonial Mozambique, sexual intercourse between African women and Portuguese men was not strictly prohibited, unlike in Southern Rhodesia. Marc Epprecht points out that 'Sea kaffirs' (Portuguese), carrying a reputation of sexual indiscipline from Mozambique, were especially worrisome to respectable Southern Rhodesians. ${ }^{82}$ Industrial officials complained that Portuguese immigrants deliberately broke every industrial law and were allegedly prepared to work under uncomfortable conditions, which a local white Rhodesian artisan would not tolerate. ${ }^{83}$ Allison Shutt and Tony King show that old settlers wanted to present a picture of Southern Rhodesia as a white man's colony where whites could achieve a higher standard of living than elsewhere. ${ }^{84}$

Another example of where unacceptable moral behaviour translated to undesirability is the case of Portuguese Joao Filipe Viegas. In February 1956, a member of the Criminal Investigation Department cautioned him after he harassed a 21-year-old white woman. Another white woman accused Viegas of constantly following her around Bulawayo, pestering her and abducting her nineteenyear-old daughter. ${ }^{85}$ In August 1956, there were complaints that Viegas was having an affair with a young coloured woman. In the opinion of the senior Social Welfare Officer,Viegas was wrecking what was otherwise a happy marriage, prompting his deportation. ${ }^{86}$ In addition, officials classified four Greeks as undesirable residents for homosexual practices, all of whom were firefighters on the Rhodesian Railways. ${ }^{87}$ In the early 1950s, a popular culture of intolerance against homosexuality coalesced in a less explicit but equally repressive form in Southern Rhodesia. ${ }^{88}$ The appearance of homosexuality within the Rhodesian settler community with its celebrated masculinity and machismo was unacceptable. The masculinity was associated with 'hard-drinking, womanising, laughing-in-the-face-of danger, at-ease-in-the-bundu (wilderness) and with Africans' ${ }^{89}$ Yet the state encountered difficulties and embarrassment when southern European whites with different sexual views entered the country in the post-war years. It was also difficult to ascertain one's undesirability in terms of sexual conduct; these are circumstances that officials tried to rectify by deporting individuals accused of indecent behaviours.

Rhodesian officials accepted immigrants with criminal records in their previous country of residence or who were involved in unlawful acts. However, some whites with criminal records entered Rhodesia as holiday makers under circumstances which the state could not detect. In 1953, Manuel Madeira De 
Faria entered the country on a holiday visit but did not declare his previous crimes in Mozambique. The government deferred his application for a residence permit when he admitted to two convictions in Lourenço Marques for assaulting Africans. ${ }^{90}$ In May 1955, when it appeared he was likely to become destitute, he admitted upon enquiry that he also had a conviction of robbery in Beira. ${ }^{91}$ De Faria was a serial criminal but he managed to enter Rhodesia, exposing the colonial state's porous borders. Later on, authorities were able to track his criminal record and deported him back to Mozambique as an undesirable immigrant. Even more embarrassing were cases of laziness portrayed by certain whites. For instance, the case of Joao Salgado Ferreira who entered the country on 9 November 1954. Employers dismissed him for laziness shortly after taking employment, prompting him to travel around the country accepting casual employment. ${ }^{92}$ This was an embarrassment to the acclaimed settler picture, as Shutt writes, of a hardworking class of whites determined to develop their country who could even work in their homes despite having mostly African servants. ${ }^{93}$ When he was later joined by his wife - three months pregnant by Ferreira's brother - and three children, his marital relationship came under strain. He left his children alone in dirty and unkempt conditions, completely neglected by their parents. ${ }^{94}$ In 1956, the government deemed him undesirable and he was deported on grounds of his morals and ethical conduct not resonating with Rhodesian settler social standards.

The case of Jose Joao provides another illustrative example. Following his entry into Southern Rhodesia in 1953, the courts had convicted him for threatening violence, possession of an unlicensed firearm and ammunition without a permit. Against established white standards, he lived in squalor in an African compound, habitually consorting with African women for sexual intercourse. ${ }^{95}$ When he entered the country, officials could not ascertain his behaviour leading to his deportation as an undesirable white immigrant in a situation where moral and criminal accusations overlapped. In 1956, the courts convicted Fernando Moreira Malia of assault occasioning bodily harm and allegedly living with a pregnant coloured woman. ${ }^{96}$ Arguably, there were other whites involved in such acts but these could not attract the states' attention because they probably belonged to a cultural category that was deemed acceptable. In 1955, the government declared Joaquim Antonio De Lemos as a prohibited immigrant and he returned to Lourenço Marques. He re-entered Rhodesia, worked as an insurance agent, and ran an informal employment bureau at Bulawayo before it came to the notice of the Immigration Authorities. ${ }^{97}$ Later, the police arrested him for secretly recruiting and importing Portuguese artisans, charging exorbitant recruitment fees. ${ }^{98}$ The government deported him because of his criminal activities and for circumventing the authorities. Another Italian, Luigi Grillo, faced 42 days' imprisonment for three counts of theft. He stole money totalling f22, 10 from a fellow railway employee, and the government declared him as undesirable and a prohibited immigrant. ${ }^{99}$ In another case, the Ministry of Home Affairs was perturbed to learn that L. P. Pafitis, a Cypriot, had been illegally resident in the Federation for five years without officials' notice. ${ }^{100}$ These 
cases go to show that Rhodesian settlers wanted to project an image of a law abiding community.

In some instances, class was central in defining immigrants as undesirable without placing emphasis on race. For example, in June 1956, two Greek plasterers and one Italian carpenter arrived in Gwelo. Officials reported that the carpenter was of a reasonable standard but the Greeks failed badly. ${ }^{101}$ One of the Greeks found work so strange that his hands blistered the first day and he eventually worked as a learner supervisor on the railways. ${ }^{102}$ At the same time, another Greek plasterer arrived in FortVictoria and his lack of ability was such that the ICEM representative removed him and put him on a day's trial with a Gwelo firm. The result of the trial was that the employer was prepared to continue his employment on the same conditions as the trial, that is, without payment of wages. ${ }^{103}$ The ICEM local representative then asked MacDonald Construction Ltd. to employ him and suggested, as an inducement, that they could pay him less than the minimum of the building agreement. Again at Fort Victoria, officials found an African helping a Greek plumber where he had gone wrong in making a sheet metal downpipe. On being informed, the employer was not too concerned and stated, 'these chaps are grafters and I can kick them around which is more than I can do to the Britisher' ${ }^{104}$ This quotation suggests that Greek workers were less white since employers could beat them just like Africans without any problem. They could not do this to British artisans who could sue them or even publicise the incident in the newspapers. It would be unfair to condemn the artisan in this case as there were very few countries where the plumber was required to do sheet metal work; he might have been quite a good plumber. It would have been acceptable if the Greek was the one showing the African where he had gone wrong, or at least would have preserved the white settler image.

Disobeying superiors at work, especially in front of Africans, also qualified white immigrants as undesirable. The cases discussed here demonstrate how ethical conduct at work and moral questions rendered other white groups as undesirable. Authorities defined the Italian Elio Jugovaz as undesirable because of his alleged unbecoming conduct in the work place. According to officials, Jugovaz was purposely obstructive in his work, subversive in his speech, rebellious against discipline and incited others to adopt an indifferent attitude towards work. ${ }^{105}$ Indeed, officials did not expect his conduct in front of Africans and the government severely reprimanded him, he lost his salary and he was eventually deported. Likewise, Pavlos Nikiforakis, a Greek, commenced work on 30 December 1955, as firefighter at the Rhodesian railways. Authorities made some enquiries regarding a delay in a shunting engine where Nikiforakis worked, resulting in him receiving two severe reprimands for absence from duty. ${ }^{106} \mathrm{He}$ also got a wage reduction for fifty-two days for absence from work. He agitated for his release from the railways and allegedly used the administration as a means to enter the Federation. The government eventually deported him on 14 September 1956 as an undesirable character showing negligence while on duty. 
Despite these fears, decolonisation on the African continent had some immediate undesired effects. The country received large numbers of immigrants from Mozambique and Angola in 1975 following the end of Portuguese colonial rule in those countries. ${ }^{107}$ Immediately after Belgium granted the Congo independence in 1960, the new country was plunged into civil war that had a psychological impact on Rhodesian whites. ${ }^{108}$ It created a sense of white solidarity against African nationalism. David Coltart's family hosted Belgian refugees, and he recalled they 'told harrowing tales of what was happening in the Congo ... the spectre of thousands of Belgian refugees in their country had a profound effect on the mind sets of white Southern Rhodesians'. ${ }^{109}$ In 1960, there were bloody riots in Southern Rhodesia as blacks protested against the colonial state's racist policies. Because of these insecurities, white solidarities, conservatism and rightwing extremism surfaced in Southern Rhodesia. The coming into power of the Rhodesian Front in 1962 and the subsequent hostilities between blacks and the settler regime had lasting effects. The fear of African nationalism forced Rhodesian settlers to embrace previously undesirable whites. However, the Rhodesian Front declared other whites as prohibited immigrants for political reasons in the 1970s. The period after the UDI ushered in a different historical moment in Rhodesian settler colonialism and significantly altered patterns of white migration. It marked a turning point of race relations in the country as armed confrontation between blacks and whites that lasted until 1979, with the dawn of the country's independence in 1980.

\section{Conclusion}

Southern Rhodesian officials considered some of the British immigrants who entered the colony in the immediate post-war years as undesirable and of the poor type. Inasmuch as the country was desperate to attract more British settlers of the "right type", the opposite happened. Colonial bureaucrats and industrial officials complained about lazy, "cotton-wool" type of whites flooding the country. The net effect of this was significant as far as the social and political terrain of the colony was concerned. Their liberal ideas were often less compatible with Rhodesian racial boundaries. However, this was not a permanent situation as some of them switched to right-wing conservatism in the later years. Being a British immigrant was not sufficient justification to claim desirable status in Rhodesian settler society's constructions of whiteness, respectability and identity politics. Claims to desirability called for more than just a legitimate claim to British cultural extraction. Class and acceptable moral conduct were essential aspects in the definition of desirability. The deportation of individuals classified as undesirable demonstrates the heterogeneity and divisions prevailing within the Rhodesian settler community before the political instabilities of the $1960 \mathrm{~s}$ and 1970s. However, whiteness tended to conceal internal tensions within the Rhodesian settler community. However, this is not enough reason to justify settler colonialism by showing that some whites were undesirable, trash or poor. Whatever the case, indeed, whites enjoyed better material benefits than Africans. 
The state was afraid that the so-called undesirable whites had the potential to upset the ambiguous British way of life in the colony and dilute the selfbuilt settler image. The Rhodesian settler community projected an image of a striving society, commanding respect and supremacy over Africans. The government expected post-war white immigrants to maintain this image associated with material privileges, respectability, good behaviour and acceptable social conduct. The presence of the so-called white immigrants and subsequent state action to police their alleged social conduct reveals more about the Rhodesian settler perceptions and prejudice towards other whites. Moreover, undesirability was an economic, political and social state-engineered and sanctioned category of identity. Immigration officials acted as classification officers of class categorisation and as gatekeepers against the penetration of undesirable whites in the country. While Rhodesian immigration officials worked hard to weed out the so-called undesirable whites, they were not always successful in carrying out their mission. The fact that unwanted white individuals entered the country exposes the porosity of colonial borders and immigration policies. On paper, Rhodesian immigration policies were selective, yet in practice undesirable white characters slipped into the country.

Undesirability was a fluid and contested category encompassing prejudice, unacceptable moral behaviours, extreme political views and class as well as criminality. The state arbitrarily applied the term undesirable depending on economic and political developments in the country. In describing both British and non-British white immigrants as undesirable, the Rhodesian settler community conflated class, race, cultural and ethnic aspects under different circumstances. The overlapping of these facets stretched the definition and usage of the term arbitrarily. Arguably, immigration officers' personal opinions and the ever shifting economic and political terrain of Rhodesia at any given moment altered the meaning of white undesirability.

\section{Notes}

1 The National Archives, London [hereafter TNA], DO 35/4831, Southern Rhodesia Immigration Regulation, 8 June 1954.

2 Ibid.

3 Lowry, 'Rhodesia 1890-1980', 123.

4 Mlambo, 'Some are More White Than Others', 139-160.

5 Mlambo, 'Building a White Man's Country', 140.

6 Good, 'Settler Colonialism in Rhodesia', 10-36; Watts, 'Killing Kith and Kin', 382-415; Murphy, 'An Intricate and Distasteful Subject', 746-777.

7 Hancock and Godwin, Rhodesians Never Die.

8 Brownell,'The Hole in Rhodesia's Bucket', 591-610; Brownell, The Collapse of Rhodesia.

9 Constantine, 'British Emigration to the Empire-Commonwealth', 25; Cavell, 'The Imperial Race and the Immigration Sieve', 346.

10 Lowry, 'Rhodesia 1890-1980', 128.

11 Schutz, 'Political Change in Rhodesia', 24.

12 Clements, Course to Collision, 65.

13 Parker, Little White Island, 25.

14 Ibid., 31. 
15 National Archives of Zimbabwe, Harare [hereafter NAZ] NAZ Oral/FL1, 13 June 1973.

16 Bonello, 'Early Settler Identity', 346.

17 Colley, 'Britishness and Otherness', 325.

18 Lambert, 'Unknown People', 602.

19 Rupiah, 'Internment Camps and Refugee Settlements', 138-139.

20 NAZ, S482/47/42, Post-war settlement and migration to Southern Rhodesia and dominions from UK, 2 October 1945.

21 Mlambo, White Immigration into Rhodesia, 4.

22 NAZ, S482/47/42, Immigration, Review of immigration into Southern Rhodesia during the month of January 1948.

23 NAZ, S482/47/42, Post-war settlement and migration to Southern Rhodesia and Dominions from UK, 2 October 1945.

24 Tavuyanago, Muguti and Hlongwana, 'Victims of the Rhodesian Immigration Policy', 954.

25 NAZ, S482/47/42, Immigration, 9 January 1947.

26 Ibid.

27 Ibid.

28 Ibid.

29 NAZ, S3556/3/332/42, Mass immigration from Britain, Satellite Towns, 2 October 1947.

30 Shutt, Manners Make a Nation, 78.

31 Clements, Course to Collision, 87.

32 Legislative Assembly Debates, 25 May 1950.

33 Ibid.

34 NAZ, F170/18, Report of the Economic Advisory Council on Immigration Policy, 5 December 1957.

35 Federal Assembly and Legislative Debates, 23 February 1956.

36 Ibid.

37 Ibid.

38 NAZ, ORAL/LL2, 2 July 1972.

39 Ibid.

40 NAZ, ORAL/PA 4, 1 March 1973.

41 TNA, DO, 35/4831, Deportation of Charles Taylor, 9 June 1954.

42 Ibid.

43 TNA, DO, 35/4831, Deportation of Charles Taylor, 28 July 1954.

44 TNA, DO, 35/4831, Commonwealth Relations Office to the High Commissioner in the Federation of Rhodesia and Nyasaland, 5 June 1954.

45 TNA, DO, 35/4831, Commonwealth Relations Office to the High Commissioner in the Federation of Rhodesia and Nyasaland, 11 June 1954.

46 TNA, DO, 35/4831, Deportation of Charles Taylor, 28 July 1954.

47 TNA, DO, 35/4831, High Commissioner in the Federation of Rhodesia and Nyasaland to the Commonwealth Relations Office, 12 June 1954.

48 TNA, DO, 35/4831, National Union of Mineworkers, 15 July 1954.

49 Daily Worker, 6 July 1954.

50 NAZ, S482/132/49, Prohibited Immigrants, 19 April 1949.

51 Ibid.

52 Lambert, 'Maintaining a British Way of Life', 59.

53 TNA, FO 371/80195, 27 January 1950.

54 Ibid.

55 Ibid.

56 Rhodesian Recorder, April 1951.

57 Ibid.

58 Association of Chambers of Rhodesia, Report of proceedings of the third annual meeting of the Association of Chambers of Industries of Rhodesia, 28 September 1944.

59 NAZ, F119/IMM/3,Vol.2, Immigration file Aliens Policy, 17 July 1958.

60 Politakis, Post-war Reconstruction of Greece, 1. 
61 NAZ, F119/IMM/3,Vol.2, Immigration Aliens Policy, 17 July 1958.

62 NAZ, F119/IMM/3,Vol.2, Alien business firms in the Federation, 17 July 1958.

63 Ibid.

64 Tischler, Light and Power, 155.

65 Lessing, Going Home, 95.

66 Ibid.

67 Tischler, Light and Power, 155.

68 NAZ, F119/IMM/3, Vol.2, Alien business firms in the federation, Immigration file Aliens Policy, 17 July 1958.

69 Ibid.

70 Ibid.

71 Ibid.

72 NAZ, S482/132/7/48, Immigration Artisans, Italian immigration, 11 February 1949.

73 NAZ, F119/IMM/3, Undesirable Greeks, Italians and Portuguese, 17 August 1956.

74 Ibid.

75 Tischler, Light and Power, 155.

76 TNA, FO, 371/80195, 21 January 1950.

77 TNA, FO, 371/80195, 5 April 1950.

78 TNA, FO, 371/80195, 7 January 1950.

79 Ibid.

80 NAZ, F119/IMM/3, Office of the chief industrial office to the secretary of home affairs, 8 January 1957.

81 Ibid.

82 Epprecht, 'Black Skin, “Cowboy” Masculinity', 257.

83 NAZ, F119/IMM/3, Undesirable Greeks, Italians and Portuguese, 22 February 1956.

84 Shutt and King, 'Imperial Rhodesians', 363.

85 NAZ, F119/IMM/3, Undesirable Greeks, Italians and Portuguese, 22 February 1956.

86 Ibid.

87 NAZ, F119/IMM/3, Undesirable Greeks, Italians and Portuguese, 4 April 1956.

88 Epprecht, 'Black skin, “Cowboy” Masculinity', 257.

89 Ibid.

90 NAZ, F119/IMM/3, Undesirable Greeks, Italians and Portuguese, 22 February 1956.

91 Ibid.

92 Ibid.

93 Shutt, Manners Make a Nation, 81.

94 NAZ, F119/IMM/3, Undesirable Greeks, Italians and Portuguese, 22 February 1956.

95 NAZ, F119/IMM/3, 4 April 1956.

96 NAZ, F119/IMM/3, 8 April 1956.

97 NAZ, F119/IMM/3, 4 April 1956.

98 Ibid.

99 Ibid.

100 NAZ, F119/IMM/2/5, British immigrants: Cypriots policy and individuals, 30 August 1960.

101 NAZ, F119/IMM/3, Undesirable Greeks, Italians and Portuguese, 4 April 1956.

102 Ibid.

103 Ibid.

104 NAZ, F119/IMM/3, 8 January 1957.

105 Ibid.

106 Ibid.

107 Mlambo, White Immigration into Rhodesia, 4.

108 Historical Papers Research Archive, University of Witwatersrand, Johannesburg, A1296, Milward, 1960-1961, 23 January 1961.

109 Coltart, The Struggle Continues, 14. 


\title{
4 White people fit for a new South Africa? State planning, policy and social response in the parastatal cities of the Vaal, 1940-1990 ${ }^{1}$
}

\author{
Bill Freund
}

\section{The poor white problem}

During the first half of the twentieth century, no issue exercised the white politicians of South Africa more than the problem of the "poor whites", remarkable if compared to the later stereotype that saw South African whites as almost all living in the lap of luxury. Johan Fourie traces written references to this apparent scourge back to $1886 .^{2} \mathrm{He}$ also characterises most explanations for white poverty to the difficulties of farming in South Africa where the AngloBoer War and then the Great Depression greatly accelerated crisis conditions and drove large numbers off the land. ${ }^{3}$ In a somewhat off-hand way however, Fourie lists a whole set of other causes and in fact these were probably also relevant often enough. Individual poverty cases will differ and may well have a dimension that is not due to macro-economic trends. ${ }^{4}$ I have argued years ago that both poverty and that "poor whites" are categories that can be defined in different ways depending on the historical context; they are not really scientific terms of any sort. ${ }^{5}$ The poor white problem was taken up as a political issue and with great enthusiasm by politicians and, for the National Party, as Lindie Koorts's recent biography of Malan reminds us, like almost no other over decades. $^{6}$ As such, economists are unable entirely to capture how the issue was understood and what really lay behind it.

The deepest connection lay in the link to racial thinking about the nature of South African society. ${ }^{7}$ Jeremy Seekings cited some years back a typical parliamentary response of the past:

The political imperative was explained by an NP MP, Dr. Stals, who had just won his seat from the South African Party. The "poor white" problem, he said: is a question which not only concerns the poor; it affects the whole white civilisation of this country. It confronts us with the question whether we, the descendents [sic] of the staunch old pioneers, will maintain their civilisation and hand it over to our children... It may be asked whether there is poverty only in South Africa and whether other countries do not suffer from the same thing. There are poor people everywhere, but the circumstances in South Africa are unique. ... In this country, there is 
a small number of whites against the natives, a few civilised people against uncivilised hordes, and for that reason it is so important that not a single white person should be allowed to go under. . . There is no greater problem than this, because the existence of the European civilisation in this country hinges on it. ${ }^{8}$

There was a more prosaic reason as well. The majority of the poor whites were potential voters and they were largely Afrikaans speakers. As Hendrik Verwoerd addressing the 1934 Afrikaner Volkskongres in the role of South Africa's first professional sociologist pointed out: 'Insover ' $n$ baie groot deel Afrikaanssprekend is, moes ons skat dat ongeveer een kwart van ons Afrikaanssprekende bevolking blanke armes is'. ${ }^{9}$ Thus the poor white question was directly political but also a cudgel for Afrikaner nationalists to take up as political competitors. Verwoerd even insisted that for the entire population, keeping whites up to reasonable civilised level was critical for the future of the country. In effect, one had to hold up the banner for what was referred to as "civilised labour". ${ }^{10}$

So how was this problem to be resolved? Thanks to the writing of Jeremy Seekings, we have a recent window on debates which marked the inter-war years in this connection. Seekings has convincingly shown that the US sponsored Carnegie Commission, meeting after 1931, was not on closer examination a turning point here as has been imagined. ${ }^{11}$ With a psychologist on its key research team and a big representation from the Dutch Reformed Church, the Commission was actually relatively hostile to the role of the state in alleviating poverty. Indeed Seekings argues that the Commission saw the poor white problem as fundamentally psychological. ${ }^{12}$ From this point of view, there were continual murmurings about the dangers of dependence, of the poor failing to meet their obligation as self-reliant Calvinists and the poisonous effect of a dole from the state. Poverty had to be linked to the troubles and weaknesses of particular individuals. This can probably also be linked to a rejection of urban life as the bright future of white South Africans. Back to the land was the sound movement. The Church (but the state as well) sponsored new agricultural settlements, for instance on the Orange River. The old view had been to leave the problems of poverty and destitution to family and church. The question of secularisation - and the resentment of the Church at being sidestepped - was an important one.

Yet Seekings argues that during the 1920s the Pact government particularly did intervene, and fairly effectively, in fighting poverty amongst white, and to a lesser extent, Coloured people (some of whom had the vote). Indeed General Hertzog liked to think that he had brought the poor white issue to a close, rather prematurely, as prime minister. Seekings goes further in taking the emphasis away from the shadowy poor white paradigm and the moralism with which it was suffused towards specific material reform in the direction of training social workers and offering material aid to dependent children and oldsters. A hallmark here was the establishment of a non-contributory old age pension scheme which took effect from the start of 1929. Another was the 1937 
Children's Act. In general, he argues that white South Africans did benefit from what was for the time a considerable start to a welfare state. Interestingly, this focus on state intervention was strongly promoted in a particular form by Verwoerd. He was particularly interested in the systematic training and diffusion of social workers, a new profession in South Africa in which he had himself been trained in the USA, who could direct the upliftment of the poor in the right way. In introducing the question of state intervention, he even referred to the potential nationalisation of the mining industry which towered over the South African business horizon.

The 1922 strike had been fought over the role of whites in the gold mines and it was a struggle which a state, determined to back the mining industry, won. ${ }^{13}$ There continued to be white workers on the gold mines but they were essentially supervisors of labour and tools of management, or genuinely skilled labour.They formed a very small percentage of the total labour force albeit that they won a much larger proportion of total take-home pay. The National Party largely, if begrudgingly, accepted this situation, but what about state employment and what about secondary industry? Well before Carnegie, a major factor as well was the willingness of the state to take on white and Coloured workers, at the expense often of Africans, in state employment. The chief exhibit for the interwar years was the railway system, ${ }^{14}$ but there were some others as well. When Parliament approved the creation of a state Iron and Steel Corporation in 1928, it was understood that it would be a resort for white workers to the greatest extent possible.

To go back for a moment to Verwoerd, he was far from the only force who thought about poverty as a sociological, not merely or even primarily, an economic construct. Parnell points us already in 1992 to the idea that proper state-initiated and supervised housing were thought also to play a civilising role in a civilising community and the Slums Act of 1934 cleared the way to the erection of what were seen as decent housing schemes to replace life in squalid pondokkies. ${ }^{15}$ Fourie also points to a feature which perhaps is the most under-researched: the role of education. ${ }^{16}$ This too can be a source of ideological intervention where workers' children are instructed in a way of behaviour and orientation and he mentions the growing educational levels of Afrikaans medium teachers during the inter-war years. However there is also the question of technical education aimed at jobs-orientated skills acquisition. This too took off in South Africa. On the whole, secular state intervention won the day in terms of the arguments for combatting white poverty. However other dimensions remain part of the picture and the assault against social ills has many prongs.

\section{Parastatal employment}

Here there was an opportunity to create entirely new settlements with no need to destroy slums and a large build-up of urban people where there had previously been none. In taking this on, there seem to be two central themes. The 
most direct is the provision of large numbers of jobs restricted to whites. The connection here to poverty alleviation was highly significant. The second, to be taken up later, is the subtler connection between what was considered advanced town planning at the time and an attempt to turn feckless white workers into what was called civilised labour. There is no automatic link between planned housing, whether or not state-owned, and racial or any other particular exclusion. This depends on the context of the society. It is true that any large-scale development built "to scale", however necessary and useful, will not please all inhabitants. This chapter seeks to explore the link that South African society held out to planning, not to condemn all planning.

There was once a very strong tendency on the part of liberal scholars and historians to contrast modern English ways of confronting social problems and organising society with the backward Boers progressing at an ox-wagon pace. Indeed segregation and apartheid were conveniently collapsed into this kind of perspective. As Seekings states, ${ }^{17}$ the range of state interventions already in place before the Carnegie Commission were themselves a deliberate thrust towards modernity married to "scientific" ideas about race and segregation, significantly promoted by Afrikaners. This is the way Steve Sparks has written about Sasol and Sasolburg, and Alan Mabin on urban planning generally, and I have tried to do the same in forthcoming work on developmentalism in South Africa. ${ }^{18}$ This is not to dismiss modernity as a racist plot but rather to understand it as an outlook that could take many forms and embrace racial division with white domination as common sense. This was true both before and after the fateful election of 1948 when the Purified Nationalists returned to power using apartheid as a slogan.

The creation and development of the parastatals had a huge impact on the economy of an increasingly prosperous South Africa, not only in the promotion of these very large firms with requisite infrastructure but in the general benefits for the expansion of heavy industry, notably in metals and chemicals. This chapter wishes to supply some evidence for this in the continuing national development after 1940, especially with reference to the entirely new towns of Vanderbijlpark and Sasolburg, created to serve the new state-initiated parastatals of ISCOR and Sasol respectively. During the 1940s and 1950s, African colonies were the site of numerous development efforts by the state which often went ludicrously or tragically wrong, but not all of the planning of that era failed to produce the desired effects. For all their social and environmental aspects which could be condemned, the key state-created industrial operations, ISCOR (steel) and Sasol (coal into oil), were in their own terms extremely successful. The London-linked money associated with the gold mines was very hostile to the creation of ISCOR. However, in time, Anglo American, the biggest private firm in South Africa, itself got into steel manufacturing on a big scale. South Africa had been Britain's largest customer for steel; this ended in the decade after World War II. For a generation, it was a great economic success story. ISCOR's privatised successor, Mittal, succeeded in selling large amounts of steel to China in more recent years moreover. Sasol today is South Africa's 
Table 4.1 Employment at Iscor by race ${ }^{19}$

\begin{tabular}{lrc}
\hline & Whites & Others (Natives, 1934) \\
\hline 1934 & 2,000 & 1,500 \\
1954 & 9,000 & 11,500 \\
1972 & 18,700 & 17,800 \\
\hline
\end{tabular}

biggest source of tax revenue and its massive new operations in the USA may well make it a major international player in the chemicals industry. These are anything but economic failures and at peak they employed very large labour forces. ${ }^{20}$

Yet already in the 1930s when ISCOR opened up its Pretoria plant, it quickly became fairly obvious that the initial idea of an all-white workforce was a fantasy. ${ }^{21}$ This was never going to be a viable case. However, it was a remarkable feature that the proportion of white workers was high, that it remained high right up to 1989 when ISCOR was privatised, and that hiring was policed in such a way that black workers were barred from all but the most primitive kinds of skill acquisition often described as "semi-skilled". ${ }^{22}$ Large numbers of whites were very well paid compared to blacks in the same factories. Thus in ISCOR in mid-1954, 9,000 whites earned $£ 50$ million, while 11,500 "Natives" earned f13 million. ${ }^{23}$

These proportions were in contrast to the mines where whites usually formed roughly only 10 per cent of the workforce. Gold, of course, was South Africa's number one export and the gold mining companies' imperative to keep white worker numbers down - admittedly with a huge percentage of the total wage bill - was consequently tolerated. As for ISCOR, worker numbers reached a peak of $76,000^{24}$ (dropping to 60,700 in mid-1982 and 49,560 at the end of 1985). ${ }^{25}$

The creation of new ISCOR mills in Vanderbijlpark in 1940 and in Newcastle in 1972 both resulted in management being obliged to cope with the requirement of maintaining a very large white labour force while the conditions of employment were such as to mop up white unemployment and indeed, until the final years, the industry created a job surplus that was problematic to fill. This was not met by excessive wages initially. Many white workers making $f^{2-3}$ per month or less in the 1950s received subsidy payments from the Department of Social Welfare. These bottom wages improved but apprentices continued to be a special category at the bottom of the wage ladder.

There remained the idea that unskilled workers were necessary but not worth much to capital. In South African terms, therefore, the issue was consequently how to train and keep genuinely skilled workers who had to be white on the job. This was a constant struggle.

There were several responses. One, about which more could certainly be researched, was education and training. The parastatals themselves ran training facilities, which were very important in producing acceptable workers. ${ }^{26}$ 
ISCOR had an excellent rate of completion of training bursaries on schedule 65 per cent instead of the usual 20 per cent - and 45 per cent of its working artisans had been trained by the company as of the start of the 1970s. ${ }^{27}$ This did not mean of course that artisans and other trained workers necessarily stayed at ISCOR or other state corporations for their entire career. Other employers paid better. However, they still entered the overall labour pool from a much improved starting point. Vanderbijlpark particularly attracted a number of industrial employers using ISCOR metal and metal products.

The parastatals were an important reason why "poor whiteism" largely disappeared as a social and political question in South Africa. It was still significant when the first two Purified National Party politicians, Malan and Strijdom, held power up to 1958 , but actually very little changed in 1948. It is a mistake from this point of view to see a dramatic shift with the onset of apartheid if by that one means the 1948-90 years when the National Party held power and promoted this slogan to replace segregation before it gave way in turn to "separate development". Concern with poor whites as a national question tended to give way to the search for a largely Afrikaans management class, particularly in state agencies. With Verwoerd in power, the system started to change significantly taken as a whole since the regime became obsessed with finding a means of building separation of the races within a white-dominated regional structure. For black South Africans, forced removals and the attempt to disrupt black urban life, although the latter was never entirely successful, meant a big change after 1958. However, for whites, the rules which enshrined earlier practices remained much the same. The economic empowerment of whites in the early apartheid years was an apotheosis of earlier policy. ${ }^{28}$

There was a constant but growing labour shortage. ${ }^{29}$ Stuart Coupe showed that for the metal and engineering trades generally, the number of white workers monopolising skills hardly increased in the boom years. ${ }^{30}$ Moreover, white South African workers with real skills were potentially quite mobile and the retention rates in the small town plants for ISCOR at Vanderbijlpark and Newcastle, were not good. Pretoria, with its more diverse economy, was better placed in this regard. However, the ISCOR plant in Pretoria lacked the space for expansion and met with increasing awareness of pollution problems, so it came to hold only a small share of operations.

A second answer lay in recruiting skilled workers in Europe, a policy that did not end for ISCOR until the last gasp of prosperity at the start of the 1980s. ${ }^{31}$ To take the example of ISCOR, these workers came not only from

Table 4.2 Iscor turnover rates p.a. $1971^{32}$

\begin{tabular}{ll}
\hline "Non-whites" & $59 \%$ \\
Operatives & $56 \%$ \\
Short service & $100 \%+$ \\
Artisans & $31 \%$ \\
Engineers & $12 \%$ \\
\hline
\end{tabular}


Britain, but from Germany, Switzerland, Sweden, Norway, Italy and the Netherlands, and later Greece. Particularly desirable were bricklayers, electricians, fitters and turners. ${ }^{33}$ In key periods such workers got a free passage to South Africa and housing with rentals fixed at a maximum of 20 per cent of their income. Beyond that, they were eligible for a Home Ownership Scheme and were required to join a workers' club. Some 27 engineers, 381 production workers and 421 artisans were hired from overseas in 1975, a late banner year. Integrating these foreigners was defined as a major task for the social services and schools. This kind of worker was unlikely to evolve quickly into a diehard Afrikaner Nationalist but everything was done to turn him into a civilised South African worker. It is also true that he was unlikely to object strongly to the racial policies which underwrote his own good wages.

A third strategy was to look for space in the workforce where management could situate white women, Coloureds and Indians. Already in the 1970s, management began to experiment with hiring women for what would previously been male jobs. This shift was obviously considered far less explosive than one fiddling with the racial ceilings. ${ }^{34}$ In addition, the 1976 Annual Report announced that there were 979 women employed in production, mostly in Vanderbijlpark and Pretoria, and there were additionally many administrative workers. However, women were still not deemed acceptable as artisans. ${ }^{35}$ The facility in Newcastle, with its large black population nearby in parts of the Zulu "homeland" and the presence of an Indian community better-primed for skilled jobs after the 1960s, also offered management some relief. ${ }^{36}$ In the middle of the 1970s, however, the refusal to train or accept workers of colour, especially in Vanderbijlpark and Pretoria, remained salient. ${ }^{37}$ Newcastle was less of a problem in theory with its Indian minority, but in fact this major new expanding facility in a town that did not have much appeal to white workers had its own difficulties in the form of high turnover. All in all, however, conditions evolved in the 1940s and 1950s so that it was the "poor whites" who began to have the upper hand in bargaining, and were able to enforce racial boundaries through their trade union, and armed by more upskilling in a very favourable labour situation. ${ }^{38}$ The problem only became less acute as the industry itself fell into crisis due to an economic downturn and slackening demand for workers. Sasol was not very different and indeed Crompton suggests that in the 1980s, security considerations favoured continuing dependence on regime-friendly whites. ${ }^{39}$ The managing director of ISCOR in 1985 pointed out to his minister that all ISCOR personnel, including management, came under systematic police and security surveillance. ${ }^{40}$

During the 1950s, the national archival record reveals ongoing concern with the question of Afrikaner employment at the parastatals. However, this was primarily a concern affecting top management and it connected most with the thrust for promoting national development under the Afrikaner nationalist aegis. It affected lower levels of staff to a limited extent, especially given the real-life conditions of labour shortages. The most important figures in the history of the parastatals were in fact Afrikaners who had emerged under the aegis 
of J.C. Smuts's United Party, notably the brilliant scientist and organiser H.J. van der Bijl, H.J. van Eck of the Industrial Development Corporation and Etienne Rousseau, key figure in Sasol. Rousseau, smarting from such criticism, quoted a message from Van der Bijl in his prime in 1945: 'Through ISKOR and other undertakings, he was doing more for the economic insertion of the Afrikaans speaker than what we are doing in Federale Volksbeleggings'. ${ }^{41}$ In a speech in his honour in 1972, Rousseau called Van der Bijl a "kampvegter" [champion] in the struggle to advance the Afrikaner. ${ }^{42}$

Despite the large numbers of whites, of course the workplace also employed a large black workforce, mainly consisting of contract workers staying in hostels and inured to harsh conditions from previous employment on the mines. The differentiation between black and white was extreme and enforced in the crudest of ways. Black overseers at ISCOR came equipped with sjamboks; white security guards and supervisors carried guns. The regime was particularly stark for hostel dwellers who had to wear special bracelets different from the house residents outside the hostel perimeter and could be confined to a detention room provided in the hostel. Hostel dwellers were largely recruited from rural sites in the Homelands, often with the assistance of chiefs, although ISCOR employees went out on recruitment drives. There was also humiliation from the naked medical examinations and the corporal punishment sometimes administered, as it was in the mines. The paternalist regime of Sasol and ISCOR and the industrial hegemony that underpinned all the early planning, based as it was on extreme inequality, was acceptable more from constraint than accord.

Furthermore, there was little or no mobility for blacks, unlike for whites. In 1967, ISCOR, which dominated the economy of Vanderbijlpark, opened up a training facility for black workers. The training consisted of a) an induction course, b) instruction in the bastard work language of Fanakalo, c) pre-school education, d) safety instructions, e) training of instructors and f) training of operators. That was it. Workers themselves remember training as being only to a limited extent about performing tasks and focussing mostly on the need to work hard and obey all whites. Fanakalo was in fact not extensively used on this account. Instead, workers were obliged to understand Afrikaans, which they resented acutely. Accident risk was discussed but in practice accidents were always defined as the fault of the worker. The compound dwellers especially were trained to see the world with racialised lenses but without of course the inherent racial assumptions of those responsible for the system. At least one popular work song summed it up: Qubula zasha, Abalungu ngodem (Lift up, damn the whites). Victor Munnik recorded the views of veteran ISCOR workers recently: 'Blacks were like tools. Where there was hard work, blacks were always taken. . . We were the first people to be the machines of ISCOR. We were the people who were doing the work of the machines of today'. ${ }^{43}$ Whites in stark contrast formed part of a Vaal Command and Sasolburg notably was the one constituency won by the far-right Herstigte Nasionale Party in a 1985 byelection. The racialised set-up in this extreme form was a major consequence of 
the "solution" to a national problem of policy confined largely to one minority racial group.

\section{Planning for race, class and family}

The core towns built for whites lay at the apex of the planning exercises. These are therefore classic suburban towns built according to plans in which particular areas reflected closely the cost and appropriate status in the parastatal world that went with positions at work, even though an increasing number of residents worked for firms other than the parastatals, albeit with parallel hierarchies. Alan Mabin has pointed out that the greatest common view of the time amongst the rising stars of urban planning was their hatred for messy, unsightly slums, their dislike of laissez-faire in urban development and their faith in what planning could do. He asks this question: 'Does this urge to control disorder and create separations characterise all modern planning?' These planning exercises were a 'marriage of modernity and racism' ${ }^{44}$

The assumption here is that the common view was applicable to most situations globally at a time when planning was gospel. However, it is important to note that the marriage to which Mabin refers was not necessarily the case universally. Thus a fascinating study of New York public housing at this time characterises its reforming proponents (often Communist Party members) as specifically intending to construct public housing in Manhattan to break down racial separation on the edge of Harlem. ${ }^{45}$ The construction of numerous housing projects at this time in some of the most affluent neighbourhoods of London where land had been cleared by wartime bombing was also in a different vein. Slum clearance also, of course, is not a despicable goal. This chapter takes the point of view that it is important to link the planning paradigm with particular South African norms and mores, not to denounce all planning or all modernity while understanding limitations and the consciousness around these trajectories.

Vanderbijlpark was laid out in 1941 on 25,000 acres purchased by the Iron and Steel Corporation of South Africa, including five miles of Vaal River frontage amounting to 40 square miles in all. For H.J. van der Bijl, who was then directing the South African economic war effort, Vanderbijlpark was a prize project that encapsulated his sense of the good life:

I visualised a town with people living in surroundings and under conditions which will be conducive to a healthy, happy and productive life. For this reason I was determined to make ample provision for parks, playing grounds, health clinics, hospitals and schools. A town, like a flower or a tree, should at each stage of its growth possess symmetry and completeness and the effect of growth should never be to destroy that unity but to give it greater purpose, not to mar that symmetry, which at all stages makes it a comprehensive whole. ${ }^{46}$ 
The 'roads [were] named after postal districts or scientists, engineers, musicians, medical men and the like' to give the town an elevated character. ${ }^{47}$ Van der Bijl had a fine house built on Beethoven Street. Great emphasis was placed on tree planting. While the town was to have a business centre with some apartment buildings, the dominant mode was suburban with an emphasis on green space and recreation and supposed isolation from industries, which were themselves to be relatively clean. The wealthiest neighbourhood around Beethoven Street still passes today, like the wealthier Northern suburbs of Johannesburg, as an urban forest.

The Vanderbijl Park Estate Company was created to produce houses on a mass scale efficiently and quickly. The goal of a new house finished every day was often realised. All of this was well developed before planning for the "Natives" even began - except on blueprint. Class differences in the white population were defining in terms of space. Particular blocks were all of a muchness in terms of size and amenity. The oldest modest parts of white Vanderbijlpark had no garages, although this changed in the 1950s. In Sasolburg, all purchased houses originally had garages but in an early phase, others were rented with only carports. In response to an indignant resident who felt demeaned by this, Minister of Economic Affairs Nico Diederichs felt obliged to respond that this was a gesture intended to benefit those who would struggle to pay higher rentals. $^{48}$

The town designer of Vanderbijlpark was Roy Kantorowich, a student of Carl Feiss at Columbia University, known for his enmity to the grand urban renewal plans of Robert Moses in New York City. Kantorowich was also implicated in the construction of the much-excoriated corporate/administrative high-rises on the reclaimed Cape Town Foreshore. Vanderbijlpark and the Foreshore evoked the two ideal forms in modernist thinking in architecture at the time: the green belt suburb with curving streets and easy avoidance of the growing menace of automotive traffic and the imposing dense high-rise for the city centre. It could be said that Kantorowich was one of a number of South African architects and planners eager to bring these ideas from the metropolitan high culture to South Africa: his greatest pride with regard to Vanderbijlpark was its contour road plan. ${ }^{49}$

Sasolburg, just south of the Vaal and inside the Orange Free State, proclaimed a white urban area in 1955, grew very rapidly until the economic crisis of the 1970s manifested itself. As with Vanderbijlpark, the plans, over which the architect-planners for a long time continued to hold control, saw Sasolburg in relative isolation, a world unto itself which was not really integrated into the farming and mining environment around the valley of the Vaal. Here, with the planning situated in the early apartheid period, streets were typically named for Afrikaners, or at least South African political figures and national heroes. Sasolburg was established under the direction of Max Kirchhofer, a Swiss immigrant who believed strongly in the green belt and was profoundly concerned with the issue of school location. He too believed that 'a town is an entity, a whole 
living organism' and that planners needed to focus on the 'self-contained residential precinct', a model easily adaptable to racial segregation. ${ }^{50}$

For Kirchhofer, as with Edwin Mallows, the British-born 'doyen of South African planning' at the University of the Witwatersrand, who worked closely with him on the site, the question of separation of automobile traffic from pedestrian usage was perhaps his biggest concern. The chief menace facing the South African town was 'the nerve-racking and dangerous intermixing of pedestrians and motor cars'. ${ }^{51}$ The cornerstone of a neighbourhood was to be the primary school to which resident children could walk safely without crossing busy roads. ${ }^{52}$ The principal environmental idea in both cities, apart from functional separation, was the massive planting of trees, including in the black locations. This forest effect is noticeable to the present day when it incurs worry as shrubbery hides criminals and pathways become littered or unkempt.

Kirchhofer was inspired by the New Towns being constructed in post-war Britain on top of ideas that came from his native Switzerland about urban citizenship and urban tidiness. He would have identified himself as a liberal and liked to consider that potentially as much thought was given to black housing in Sasolburg as to white. ${ }^{53}$ In the factors that he took as professionally important, the black population had the same needs as the white and these were accordingly accommodated, or so he was convinced.Yet "organisms" could display gross inequalities and in Sasolburg, they did. Moreover in Sasolburg, typical of many South African cities of the day, a curfew for Africans operated by decree after 9 PM. The Vanderbijl Park town clerk opined in 1952 that it is the Committee's policy to endeavour to keep the natives out of the European areas as far as possible. For this reason steps have been taken to provide shops, recreation and social centres and a clinic at Bopelong'. ${ }^{54}$ Not only did these small townships have little planned business districts, there was even a hope that they would develop craft centres and reach the ideal that blacks would rarely have to be spotted in the white town.

However, what is perhaps even more striking than the tiered layers of demarcation created by housing is the extent to which the white town in both cases was intended to civilise the paler skinned natives. White louts unused to urban living were to be made accustomed to a regime of suburban neatness and order and hopefully rendered suitable for further social and material mobility, while foreigners unused to the South African "way of life" had to be domesticated. Club membership for immigrant ISCOR employees was a requirement. It was hoped that the system of amenities, much of it sporting, would also have a socialising effect. In time, VESCO, the planning agency, actually introduced large African fauna to Vanderbijlpark (which abutted the Vaal) as a symbol of desirable appreciation of the national environment. ${ }^{55}$ Sasolburg was equipped with a botanical garden and a bird sanctuary. ${ }^{56}$ Those numerous men hired who were not married were placed in controlled situations - specially designed hostels with appropriate recreational facilities nearby. Residential areas were placed separately from business premises. Churches were located far from spots where 
men might take to drinking. Neat lawns were supposed to stay clear of rusting old cars and other working-class or farm boy appurtenances.

In a correspondence over what was termed "backyard development", the Swiss Kirchhofer considered that untidy backyards were a throwback to rural living that needed to be eliminated through strict regulation according to his big plan. They were due to the fact that

living in towns is a new experience for a large portion of the white population of this country. It is understandable that the backvelder when he moves into the closely knit urban pattern will bring with him a mode of life conditioned by the vast open spaces.... A certain amount of guidance would be helpful and strict application of the laws should do the rest. ${ }^{57}$

This, he argued, was better than the official idea of concentrating on hiding views of the backyards. For a long time in both towns, authorities attempted to enforce planning regulations that fitted the original plans of the architects approved by the state. It was claimed in 1949 by ISCOR that 'the Company will not permit any alterations or additions to the existing buildings, which will tend to destroy the character of the buildings in terms of the Establishment designed for use as a dwelling for a single family'. The Archives are replete with detailed correspondence about proposed alterations through the 1970s. However, this and other aspects of the model town order, was a never-ending struggle.

Reality was a bit more complex than the exhaustive planning exercise. Sasolburg was probably created with the desideratum that domestic workers should be forced to live in the location rather than 'accommodating them on the European premises' - something that proved impossible to enforce. Kirchhofer fended off any responsibility for this later. 'All squatting was to be prohibited' ${ }^{58}$ However, before permanent dwellings were available, where were the workers to stay? From the beginning, squatting was hard to control. ${ }^{59}$ The female domestic workers who were permitted to live on premises inevitably had male visitors and, more furtively, resident lovers or husbands whose residence promoted the availability of workers to the employer. It could not possibly be illegitimate for these women to go to church and worship God, but that required inevitably large black crowds walking through white Sasolburg, for instance, on a Sunday. Another anomaly in the system, critical in the phase where black labour was in heavy demand, was the apparent right of potential workers to spend the first 72 hours in a proclaimed white area without an endorsed pass while looking for work. Finally, there was the problem of legitimate workers for whom there was no legitimate space in the townships. A fascinating memorandum from 1958 points to the large presence in Sasolburg of men and children in servants' quarters; the domestic workers were successful in agitating to the end that there would be no work for the white household if these were expelled with nowhere to go. ${ }^{60}$ Such households were obviously tempted to wink at regulations vis-à-vis Sasol workers if they had a satisfactory arrangement with their employees. 


\section{Indocility}

Life in a regulated small industrial city was less attractive to a workforce than was imagined in the dreams of van der Bijl and the city planners. Workers had their own ideas about what they were doing with their lives ${ }^{61}$ It is not entirely by chance that the most famous Afrikaner anti-establishment rock and roller, Johannes Kerkorrel, came from a modest home in Sasolburg. Whites exhibited both a loyalty critical in some respects to the whole parastatal-governmental authority but they sought to carve out space that did not always fit what the authority desired or sometimes even opposed. Regimentation for whites bred rebelliousness.

Real life did not by any means entirely follow the dictates of civilised labour. Whites who did not like the controlling regime of the company towns also turned to the countryside where they could lead an unregulated or much less regulated existence. This also involved business possibilities, illegal or unregulated. On a little property, a man could keep a few cows and grow some maize as well as tinker at rusty machinery and fix cars. In time, many white families, for example, settled in what became known as Greater Steel Valley, close to the ISCOR factory, on some 600 smallholdings. ${ }^{62}$ This was originally defined as a waste disposal area but got settled anyway. Here ISCOR employees engaged in multi-tasked, multi-income lives on land that was disastrously polluted well outside the regulated world of the town.

The Verwoerdian system tried to put itself forward as apartheid, racial separation. It put itself forward as different from crude racial mastery by whites or, to take the familiar Afrikaans expression, baasskap. I would propose that workingclass whites generally enjoyed and profited from baasskap but were not necessarily taken with racial separation. Resident whites may have been keen on racism and racial laws, but they also sometimes profited from illegal activities and sponsored them themselves. Like the black residents, they often preferred to shop in the multi-use Vereeniging centre rather than the planned precincts of the new towns. ${ }^{63}$ As was generally true in the Vaal Triangle region, smallholdings housed not only white individuals and families but workers and other black residents in time-honoured fashion. In 1967, a survey by the Vanderbijlpark Council found 4,555 Africans in the surrounding area. ${ }^{64}$ This was also true south of the Vaal around Sasolburg, albeit less densely. ${ }^{65}$ Some were temporary ISCOR construction workers. Only 353 were farmworkers legally employed but the largest number were domestic workers, employees doing work other than agricultural work, and minors. In the official records, bureaucrats were plagued with complaints by white residents about supposedly illegal black activities and presence, although generally found to be more or less legal in fact.

The Vaal Triangle towns were very largely a black and white world. Only in Vereeniging were there established communities of Indian traders and workers and a small settled population of mixed race. Neither Indian nor Coloured people were officially welcome in Vanderbijlpark or Sasolburg. ${ }^{66}$ Sasolburg was in fact located south of the river in the Orange Free State, where Indian residence 
was illegal. The small Coloured presence in Vanderbijlpark (even smaller in Sasolburg) was a source of ongoing if low-key official anxiety, as there was no "group area" to house the handful employed there. ${ }^{67}$ Finally, an attempt was made to move all the Coloured people in the Triangle to Grasmere outsideVereeniging. ${ }^{6}{ }^{6}$ However, apart from the misery it caused, this was quite impractical and led to Coloured people living illegally on peri-urban properties or elsewhere. ${ }^{69}$

Moreover, for other transactions involving sex and other relations between men and women, marijuana, gambling opportunities or, above all, beer, there was a difficult to control world of peripheral peri-urban properties. In the Verwoerd era, trawling the peri-urban sea was an important but unending task for mariner policemen. ${ }^{70}$ Here it was possible to find ramshackle businesses of all sorts. Owners might be absent; in a few cases, they were themselves not white and here transgressions could occur. Thus, in 1954, officialdom discovered that a whole row of Indian-owned shops and houses could be found at the southern border of Vanderbijlpark on the property of a Coloured woman, Susan Wessels, married to an Indian man described as a general dealer named Kajee Omar. However, some of these shops appeared to be rented from white men in Vereeniging. This typical anomaly was shut down but would reappear in new guises. ${ }^{71}$ In 1961, state agents found once again the row of Indian shops on the south end of Bophelong, rented from white women in Vereeniging, this time full of white shoppers who preferred it to the carefully planned town centre. This zone included Chinese businesses that bore the traces of gambling for the day's horse races. ${ }^{72}$ From Zamdela, the Sasolburg township, while it was true that it was rather easy for black residents to walk to the Sasol entrance, the reality was one of littered, unsanitary and potentially even dangerous footpaths by the dozen. Moreover, Sasolburg had attracted African Explosives and Chemicals Industries and other employers, creating more complicated trajectories that could hardly be stopped. ${ }^{73}$ This irregularity had already irritated the planners twenty years earlier in Vanderbijlpark. ${ }^{74}$ These very conditions that had so horrified early city fathers in Johannesburg, in Vrededorp and Fordsburg early in the twentieth century, simply recreated themselves, albeit on terms rather more favourable to white workers.

An apocryphal bit of Sasolburg urban legend was the monthly encounter at the Sasol factory gate between husband and wife. The wife took the money required for household necessities immediately on payment and the husband then went off with his mates for a major weekend drinking bout, marking an incomplete if perhaps predictable social transition from the point of view of the planners. Whites occasionally exploded outside the confines of the company controls. In Vanderbijlpark, a resident who worked for Metal Box recalled that in the early days, 'there was one pub and it saw fights every night' ${ }^{75}$ This in turn meant that white civil society required not merely the intervention of the churches but of welfare and charitable organisations with a mission to intervene in acute social problems. Far from sounding the knell on religious and aligned interventions, these company towns offered extensive new possibilities. The Red Cross, Noodhulpliga, Kindersorg, Family and Marriage Society of 
South Africa, the Cancer Union, Kreupelsorg and the South African National Council for Alcoholism had no problem keeping busy on the Vaal. ${ }^{76}$

These activities could not be considered as resistance to ISCOR; indocility captures the reality better. ${ }^{77}$ It was only after the end of the apartheid government that residents felt empowered to engage in protest against the big employer, which apart from employing the majority, was also sometimes the provider of credit. ${ }^{78}$ Until apartheid broke, it was reported that ISCOR people tended 'to work for ISCOR for their whole lives and you step into a culture of how people do things'. ${ }^{79}$ Moreover, even the white smallholders were bound to ISCOR by the accepted dictates of security in a beleaguered white South Africa; many were members of an ISCOR Command.

\section{Conclusion}

The new towns of the Vaal went hand in hand with massive new job opportunities for the poor whites of South Africa. Whites had many arrows in their quiver to rule out African competition for their jobs even though considerable migrant labour was necessarily brought to ISCOR and Sasol to meet part of the needs of management. Indeed by the end of the 1950s, the situation in the parastatals was best characterised in terms of labour shortage. There were extensive opportunities for whites to acquire skills that made them increasingly independent of state patronage with time. It is less clear if what we might term high modernist cultural forms, notably in the planning and organisation of these towns, were very successful in diffusing notions of suburban respectability. The former poor whites had their own ideas about how they wanted to organise their lives under increasingly favourable conditions.

Fourie has made a very welcome and important intervention in proposing that current analyses of poor whites ought to consider the situation of poor black South Africans today, even if his insistence on the efficacy of home ownership as a solution may be less than convincing. ${ }^{80}$ Nothing is more central than the struggle against unemployment and overly precarious forms of labour even though, as a recent collection reminds us, this can only be a long and complex set of interventions that will also require far more co-ordination. ${ }^{81}$ The role of skill endowment and of education cannot be overestimated here. This enables individuals to find new possibilities and new situations even if a particular employer is no longer able to provide work. Parnell's point about the centrality of housing, carried through in our assessment of the planning involved in the Vaal Triangle towns, is not without a strong echo in the social housing policies carried through by the African National Congress since 1994. Moreover, there is probably an equivalent, even under the most positive conditions, of discomfort and rebelliousness as the beneficiaries of development programmes take up directions that authorities do not expect. It is important to see historical development as the result not only of state legislation and decrees, not only as the product of the plans of private and public sector bureaucrats, but that the poor, whether or not white, also have agency. The poor white question entangled 
moral and racial ideology together with practical economic questions. This analysis hopefully takes the positive benefits of modernisation in tow without missing the negative side, which abstracted from economic considerations to insist on a paternalist vision that was impossible to be enacted without struggle and indocile reactions.

\section{Notes}

1 I have to thank for their personal guidance on this material in particular Steve Sparks, Alan Mabin,Victor Munnik and Mark Oranje. This work draws heavily upon material from within B. Freund, Twentieth Century South Africa: A Developmental History, 2019 (C) published by Cambridge University Press, reproduced with permission.

2 Fourie, 'South African Poor White Problem'.

3 See also Seekings, 'The Carnegie Commission', 518.

4 For a sordid tale that dramatically highlights the interrelationships of small town and rural poor whites, landowners and black farmworkers, economic, criminal and social behaviour at the turn of the twentieth century, see Krikler, 'South African Murder'. The plot concerns the alleged murder of a white tenant by the landowner who is having an affair with the tenant's wife in the Volksrust area of the Transvaal.

5 Freund, 'Introduction: The Poor Whites', xiii-xxiii.

6 Koorts, D.F. Malan.

7 Dubow, Scientific Racism.

8 Seekings, 'Origins of South Africa's Welfare State'.

9 'Insofar as a very large part [of the poor white population] is Afrikaans-speaking, we must estimate that perhaps one-quarter of our Afrikaans-speaking population are poor whites.' My translation. Hendrik Verwoerd in Joubert, Toe Witmense Arm Was, 54.

10 Seekings, 'Origins of South Africa's Welfare State', 9.

11 Seekings, 'The Carnegie Commission'.

12 Ibid., 520.

13 Davies, Capital, State and White Labour; Krikler, White Rising;Yudelman, Emergence of Modern South Africa.

14 Pirie, 'White Railway Labour'.

15 Parnell, 'Slums, Segregation and Poor Whites'.

16 Fourie, 'South African Poor White Problem'.

17 Seekings, 'The Carnegie Commission', 519.

18 Freund, Twentieth Century South Africa; Mabin, 'Legacies of Modernism', 560; Sparks, 'South Africa's Oil from Coal Project'.

19 NASA MES 232, H 4/12 pts 1/2; MPP 45, A3/10/9, part 1.

20 For more on this, see my volume with Cambridge University Press, Twentieth Century South Africa; A Developmental History. I am very grateful to CUP for allowing me to excerpt material from this manuscript in this paper.

21 Morris and Kaplan, 'Labour Policy in a State Corporation'; Davies, Kaplan, Morris and O'Meara, 'Class Struggles'.

22 Webster, Cast in a Racial Mould looks at the heavy metal sector of industry from the perspective of the labour process and the conjuncture of Taylorism and South African racial divisions. He paid attention to the general situation of black labour migrants as well as whites with recognised skills and did some research in the Vanderbijlpark firm of Vecor.

23 National Archives of South Africa (hereafter NASA) MES 232, H 4/12, pts. 1/2, Annual Report 1955.

24 NASA MPP 17, A3/1/6/4/4 part 1, Unconfirmed Board Minutes, ISCOR, 30 January 1985.

25 NASA MPP 17, A3/1/6/4/4, ISCOR Annual Report to Minister, 31 December 1985. 
26 NASA MPP 233 H/4 12 vol. 3, Memorandum from Admin. Director J. P. Coetzee to Minister of Economic Affairs O. Horwood, 10 September 1974.

27 NASA, MPP 23, A3/10/1 part 1, LCJ de Villiers, ISCOR Personnel Manager, Report on Manpower, May 1971.

28 For an extensive articulation of this, dividing the apartheid years into three periods, see Freund, Twentieth Century South Africa.

29 Schirmer, Sunday Times, 26 January 1969; NASA MES 244, H4/12/3 v.2, ISCOR Annual Report 1965.

30 Coupe, 'Divisions of Labour'.

31 NASA MPP 51, A3/10/9 Verslae en Notules, ISCOR Monthly Report, 30 September 1981.

32 NASA MPP 23, A3/10/1 part 1, LCJ de Villiers, Personnel Manager, Report on Manpower, May 1971.

33 NASA BTS no volume 8/19/5, Facts about employment with ISCOR in Vanderbijl Park cyclostyled, for prospective employees; Secretary of Domestic Affairs to Secretary, Foreign Affairs, 29 May 1951; AES 13, AM 7/7 part 1; Annual Report ISCOR 1963; Secretary, Ministry of Trade and Industry to Secretary, Ministry of Foreign Affairs, 9 September 1963.

34 NASA MPP 23, A3/10/1 part 1, LCJ de Villiers, Personnel Manager, ISCOR, Report on Manpower, May 1971.

35 NASA MPP 45, 3/10/9 part 1, ISCOR Annual Report 1976.

36 Ibid.

37 NASA AFE 30, E4/12/3.

38 Webster, Cast in a Racial Mould.

39 Crompton, 'The South African Commodity Plastics Filiere', 157.

40 NASA MPP 17, A3/1/6/4/4 part 1, F P Kotze, Mg Director, ISCOR to D J de Villiers, Min of Trade and Industries, 1 April 1985, extremely secret.

41 NASA MES 218, H 46/6 v. 1 and 46/7. My translation.

42 Engineers' Liaison Committee of Pretoria, Hendrik van der Bijl Lesings-Lectures 196372, Address by P.E. Rousseau 1972, 123.

43 Munnik, 'Discursive Power and Environmental Justice'.

44 Mabin, 'Legacies of Modernism', 560. Mabin has also shown that the model outlined below was prefigured in existing settlements from the time that industrial-level economic activity took off in Mabin, 'Origins of Residential Segregation in Kimberley'. In Kimberley however what were defined as slums needed to be destroyed.

45 Zipp, Manhattan Projects.

46 Sasol Papers, Cullen Library, University of the Witwatersrand (hereafter Sasol Papers), AG 2207, F21 P. Nell, An Historical Review of the Town of Vanderbijl Park for the Period 1941 to December 1951, Van Riebeeck Festival Committee, Vanderbijl Park, 3.

47 Ibid., 5.

48 NASA MES 218, H 46/6 v. 1 and 46/7, Diederichs to Mev. C. F. Cilliers, 28 July 1959.

49 Kantorowich, Interview with Alan Mabin, 1991.

50 For Kirchhofer's vision, see Kirchhofer, 'Sasolburg OFS'. See also Sasol Papers, AG 2207, B4, Notes on the Planning of Sasolburg, 1957.

51 Sasol Papers, AG 2207, B4, Max Kirchhofer to D.P. de Villiers, 3 August 1957. As occasionally appears in correspondence, Kirchhofer's largest anxiety insofar as the Plan was adhered to, was the inevitable proximity of white suburbia to a giant chemical plant. He believed that Sasolburg was too hemmed in and would be prey to the chemical plant's 'smoke and smell'. However, he also thought that tree planting would solve the problem. In fact he had far less space with which to work than did Kantorowich atVanderbijlpark.

52 Kirchhofer, 'Sasolburg OFS', 26.

53 Beavon records for Johannesburg also apparently benign plans to suit garden city cities both for Orlando before World War II and Dube afterwards in considering the origins 
of Soweto, Beavon, Johannesburg, 121-130. However, such plans were trimmed down dramatically in reality and the Vaal Triangle would also display this truncated planners' vision when it came to African inhabitants' neighbourhoods.

54 Sasol Papers, AG 2207, F21, Nell, Town of Vanderbijl Park, 15.

55 The game park near the river housed at peak four rhinoceroses, two lions, 57 springbok and 29 impala. However, the lions were overly confined and the rhinoceroses ate up the bush excessively. Most of the game died out. The goal remained 'quality outdoor recreation'. Sasol Papers, AG 2207, F30, Mallows, Louw and Hoffe, Vanderbijlpark Riverside: A Proposed Development Plan for the Vaal River Front, 1973

56 NASA GMO v. 1/ 7234, Max Kirchhofer, Guide Plan for Sasolburg, November 1975, Notes. In effect Max Kirchhofer was really concerned with the aesthetic and did not come to grips with the basic environmental issues. For early environmental issues that were surfacing in Sasolburg from 1960, see NA ARB 1226, 1042/11/952.

57 Sasol Papers, AG 2207, B4, Max Kirchhofer to D.P. de Villiers, 3 August 1957.

58 Sasol Papers, AG 2207, B1, Interview with Director, Native Labour, 23 July 1951.

59 NASA NTS 6134, 481/313N, P.E. Rousseau to Verwoerd, 26/8/52.

60 NASA BA9268, A15/1603. Regulations for Management of Bantu Residents, Sasolburg; WHS Sharp, Secretary-Treasurer, Village Administration of Sasolburg to Native Commissioner, Vereeniging, 15 January 1958.

61 For an interesting parallel, see Harrison and Zack, 'The Wrong Side of the Mining Belt?' Especially their comments on South Hills (Johannesburg) public housing. Here too the planners originally entitled their project Welfare City and were filled with good intentions aimed at civilising poor white residents.

62 See map, NA BAO 1561,A18/1709 pt. 1.

63 Prinsloo (ed), Yskor; Vanderbijlpark-Werke 1943-93, Unpublished ms. (Potchefstoom Universiteit vir Christelike Hoër Onderwys 1993).

64 NASA, BAO 8005, 164/1708, part 1, Head Commissioner, Bantu Affairs to Secretary, Bantu Affairs, 9/6/67.

65 NASA NTS 5846, 481/313/M, Memorandum, Secretary, Administration of Native Affairs, 4/4/57 with further letter 29/4/57 and record of meeting 27/3/58.

66 The 1960 census counted no Asians and 110 Coloured persons in Sasolburg, largely domestic workers. NASA ARG v. 163 VK 132/1/14, 1 Verwysings van Beplanningskomitee, verslae: Town Council of Vanderbijl Park, 1953 Memorandum on the Proclamation of Group Areas. NASA GMO v. 1/7234, Sosiografie.

67 NASA, NTS 7064, 404/322, P Nell, Town Clerk to Native Commissioner, Vereeniging, 18/3/56; BEP 506, G7/550 1 and 2, W H S Sharp, Secretary,Village Board of Management to Provincial Secretary, Bloemfontein, 8/8/60.

68 NASA, BAO 1561, A18/1709/pt. 1, JS Campbell, Ag. Town Clerk to Secretary, BAD, 6/7/ 1962.

69 NASA, BAO 1747, A19/1603 v. 1, W H Sharp, Town Clerk, Sasolburg to Secretary, Department of Planning, 22/5/69.

70 This official suggested setting up a Labour Tenants Control Board to this end. NASA, BAO 9575, B23/5/1603, CP Barnaard, official entrusted with the carrying out of Chapter 4 regulations to First Administrative Official, Squatter Management, 11/10/62.

71 NASA BEP 228, G7/170/7, Enclosure in P R Nell, Town Clerk, to Land Tenure Advisory Board, 24/5/54.

72 NASA, BEP 228, G7/170, Groepsgebiede te Vanderbijlpark, 2/10/62, Gemeenteskapreport.

73 Sasol Papers, AG 2207, K1, M. C. Tisdall, Manager, Production of Co-ordination and Despatch, to General Manager, SBD, Sasol, 16/7/76.

74 NASA NTS 7064, 404/322, P Nell, Town Clerk to Native Commissioner, Vereeniging, 25/3/54.

75 Prinsloo (ed), Yskor; Vanderbijlpark-Werke, 166. 
76 Ibid., 167.

77 My larger project concerns itself in some detail with the changing situation of black residents in these urban areas far from any so-called Homeland and without any urban tradition largely left out here.

78 Prinsloo (ed) 'Yskor'; Munnik, 'Discursive Power and Environmental Justice', 118.

79 Munnik, 'Discursive Power and Environmental Justice', 274.

80 Fourie, 'The South African Poor White Problem'.

81 Black, Towards Employment-Intensive Growth. 


\title{
5 Whites, but not quite \\ Settler imaginations in late colonial \\ Mozambique, c. 1951-1964
}

\author{
Caio Simões de Araújo
}

\section{Introduction}

The poor white problem remains an ever-present, although elusive, topic in the literature on Portugal's late colonialism in Africa. While the social and political life of the white settler community in Angola has been studied in some detail and resulted in important book-length publications, ${ }^{1}$ in the case of Mozambique this issue has not yet received the same scholarly attention, with the notable exceptions of Cláudia Castelo and Jeanne Marrie Penvenne. ${ }^{2}$ This relative silence can be only partially explained by the drastic imbalance in the demographic make-up of those two settler colonies: while the black African population of Mozambique was always significantly larger than that of Angola, the former's European community never grew to the same dimensions as the latter. ${ }^{3}$ Relative proximity to Portugal and intense economic development in the post-war period made of Angola a prime destination for Portuguese settlers. Yet it was the racial politics of decolonising Africa that brought this case to the spotlight, in both academic and political circles. As the Congo Crisis unravelled beyond the northern border, in March 1961 Angola was witness to a series of violent clashes between anti-colonial actors, the African population and white settlers, resulting in a sizeable death toll on both sides of the colonial divide in the ensuing months. ${ }^{4}$ In comparison, while an armed struggle was waged in Mozambique from 1964 onwards, settler-led violence, or white terrorism, did not take place in such a widespread manner until 1974, when formal decolonisation was already in motion. ${ }^{5}$ Unlike their Angolan counterparts, moreover, Mozambique settlers did not launch a formal political movement even when their discontent against the metropole ran high. ${ }^{6}$

Of course, while one can certainly argue that the "settler colonial situation" in Mozambique was unusual, that is not to say it was a minor or irrelevant affair. If the relatively scant white presence resulted from a lack of opportunity on the ground, the long-standing economic dependency on its neighbours worked to entangle colonial Mozambique in a regional system of white privilege and rule. While historians tend to agree that here this "proximity" - however understood - to South Africa and Southern Rhodesia was consequential in shaping settler culture and society, this is a point made generically, and, therefore, 
still invites further study and scrutiny. ${ }^{7}$ In my view, this is important because, despite the increasing scholarly interest on the transnational nature of racial and imperial formations, race and empire remain compartmentalised fields of study, particularly along geographic or linguistic lines. ${ }^{8}$ Even though "settler colonial phenomena" have been described as "inherently transnational and transcultural', ${ }^{9}$ the specialised literature has been typically restricted to former British colonies..$^{10}$ Indeed, the emerging field of Settler Colonial Studies has resonated little in the historiography of, say, the French or the Portuguese empires. ${ }^{11}$ Likewise, histories of colonial racism tend to reify formal political boundaries by concentrating on the relationships between coloniser and colonised alone, which can work to sideline the often influential role of inter-imperial or transcolonial conversations and connections in shaping racial politics and thinking, in the metropole and colonies alike. ${ }^{12}$

In this chapter, I intend to bridge this gap by articulating the scholarly debate on settler colonialism to my own research on the racial politics of late Portuguese rule in Mozambique. Here, I am interested in exploring the analytical potential of Veracini's argument that the "settler colonial situation" is a distinctive historical formation, both transnational and relational in nature. ${ }^{13}$ In particular, Veracini has argued that a settler colonial project is always entrenched in a "spectrum of comparison", i.e. comparison between the settler society and the metropolitan "home", and between different settler states and their respective projects. ${ }^{14}$ This transnational and comparative dimension, I argue, puts in evidence some contradictions and dynamics that are otherwise sidelined in histories centred on the metropole-colony axis alone. In this chapter, I examine the settler situation in Mozambique not only as a Portuguese imperial affair, but also as a context associated to broader international debates on the future of European presence in Africa and to the analogous experience of South Africa. In order to do so, I engage sources that are evocative of both local concerns and transnational sensibilities, from the colonial press to diplomatic correspondence. The "poor white problem", I contend, can be productively read in this way, across different scales. This is relevant because, while most historians tend to briefly mention the lower-class status of settlers as a distinctive attribute of Portuguese colonial society, much is yet to be done in the way of exploring what Cláudia Castelo has identified as the representations and phantoms surrounding this group. ${ }^{15}$

\section{Luso-tropical visions, settler paradise: Colonial settlerism in theory and practice}

In 1953, Portugal's minister for the Overseas Territories, Sarmento Rodrigues, publicly spoke of the principles and goals orienting the country's overseas policy. His speech focused on the newly launched First Development Plan (Plano de Fomento), a substantial public investment package geared to boost economic growth in Portuguese territories by supporting agricultural production, facilitating the exploitation of natural resources and, above all, improving 
transport and communication networks. ${ }^{16}$ Beyond infrastructural development, Rodrigues emphasised the decisive role white settlement was to play in the near future. Without a considerable increase in the white population overseas, he argued, 'we cannot expect true progress, which includes the efficient and permanent defence of our territories, and their perfect nationalization. ${ }^{17}$ While 'improving living conditions and economic growth' would facilitate white settlement overseas, the state should proceed with caution. After all, Rodrigues remarked, white settlement 'does not mean transferring - without studies, preparation and sometimes painful experiments - the human masses that find themselves vulnerable in Europe'. ${ }^{18}$

In my view, Rodrigues's speech is expressive of the tensions and contradictions permeating Portuguese - and, more generally, European - colonial thought and policy in the mid-century. Although, in retrospect, the post-war era may appear to have been inevitably heading to decolonisation as an endpoint, historical scholarship has showed that the late 1940s and 1950s were a period of recalibration and restyling of Europe's relations to the colonial world. ${ }^{19}$ Certainly, this included steps towards greater autonomy and, at times, negotiated transfers of power. But it also involved European aspirations and strategies of revival and renewal of empire. This "second colonial occupation", as Low and Lonsdale convincingly put it, ${ }^{20}$ animated political, economic and ideological change, ranging from legal and constitutional reforms, unprecedented commitment to colonial development, and the espousal of various gradations of an anti-racist rhetoric, particularly at a time when racial thinking and discrimination were rapidly falling into disrepute. ${ }^{21}$ Portugal was not immune to these continental and global tendencies, even though here they assumed a particular expression, shaped by financial constraints and the political and ideological conservatism of the Salazar regime. ${ }^{22}$ The Portuguese post-war settlement policy must be situated against this background.

Politically, Portugal resorted to the reaffirmation of national-imperial unity by introducing a constitutional revision whose main innovation was to abandon the concept of "colonial empire". The term "overseas province" conveniently replaced the politically charged word "colony" to suggest that the non-European territories were integral parts of the motherland. As Bandeira Jerônimo and Costa Pinto have argued, this constitutional unmaking of the empire 'reinvented national identity [and] reinforced mythologies of national and imperial exceptionality'. ${ }^{23}$ As the same authors point out, in addition to legal change, increased public investment in modernisation and development also intended to encourage the integration of all parts of the newly defined nation. ${ }^{24}$ While the First Development Plan was the most significant expression of this policy, other measures were devised to cultivate closer ties within the "Portuguese world". This included an unprecedented investment in colonial scientific research, an expanded bureaucratic and security apparatus, and the encouragement of migration flows to the overseas provinces, by either voluntary movement or under the auspices of settlement schemes. ${ }^{25}$ It is in this context that Minister Sarmento Rodrigues stressed that white settlement was a 
condition for 'the efficient and permanent defence of our territories, and their perfect nationalization'. ${ }^{26}$

Besides its political expediency, the turn to state settlerism as an imperative of post-war imperial renewal was, too, marked by the critical recalibration of Portuguese colonial discourse and thought, of which Rodrigues's tenure at the head of the Ministry for the Overseas Territories was in itself an indicator. It was with Rodrigues's approval that, in 1951, the Brazilian sociologist Gilberto Freyre conducted a notorious research trip to Portugal and its overseas territories as an official guest. Since the 1930s, Freyre had espoused the idea that the Portuguese colonisation of the tropics had been benign and largely free of racial prejudice. ${ }^{27}$ During his 1951 travels, Freyre coined the term "Luso-tropical" to refer to the "complex of civilization" resulting from the Portuguese ability "to integrate [non-European] native peoples and cultures' into a new society. ${ }^{28}$ As Castelo has showed, while in earlier periods Freyre's ideas had failed to resonate amongst a Portuguese elite still committed to racial thinking and eugenics, ${ }^{29}$ from the mid-century his "Luso-tropicalism" was embraced as a semi-official ideology of the regime. ${ }^{30}$ At a moment when the national-imperial politics were being redefined in Portugal, the Freyrian argument that social plasticity and the "vocation to colonise" were hard-wired into Portuguese culture gained currency. Culture, however, was understood in clearly racialised terms. As Castelo pointed out, the 'psychosocial characteristics that Freyre attributed to the Portuguese were innate and were present at any time or place'. ${ }^{31}$ The white settler - as a racial and cultural agent - was the main protagonist of the process of Luso-tropical formation.

That white settlement and a multiracial rhetoric were to so decisively rise to the frontline of the post-war politics of imperial renewal may appear odd if examined against the historical record. Much effort has been invested in showing how the Luso-tropical thesis was inaccurate at best, if not simply wrong. ${ }^{32}$ For instance, while racial mixing in Portuguese Africa existed as a historical practice, it was not generalised or free of social stigma. ${ }^{33}$ Neither did it result from a peculiar vocation to miscegenation. ${ }^{34}$ Likewise, for most colonial history, white settlement in Portuguese Africa had been rather scarce. Although Mozambique and Angola had been deemed as potential settler colonies since the late nineteenth century, no consensus existed on whether massive European settlement was desirable or even possible, in racial and climatic terms. ${ }^{35}$ While in the first half of the twentieth century the white population of these territories increased as a result of expanding colonial bureaucracy and economic development, ${ }^{36}$ no public initiative was carried out, as the few existing projects failed to materialise. ${ }^{37}$ The state position until the 1940s was, in fact, marked by public inertia coupled with the active discouragement of private initiative. ${ }^{38}$ In face of tight state control intended to fight unemployment and prevent the formation of a class of poor whites, migration to the colonies was limited to civil servants and skilled labourers. ${ }^{39}$

What, then, explains the rise of colonial settlerism in the mid-century? Here, I borrow the term from James Belich's work to name a more or less articulate 
ideology by which the standing of colonial migration shifted in official discourse, public debate and popular culture. ${ }^{40}$ Contextual differences aside, the mid-century saw an explosion of efforts and debates on how to better channel Portuguese emigration to the overseas provinces, to a point at which, by the end of the decade, settlement was dubbed, in the Portuguese National Assembly, as 'the fundamental question that dominates all other issue'. ${ }^{41}$ In the literature, this shift in political tone and policy priorities has often been described as an anachronism, the product of a conservative regime unable to face and digest the reality of impending decolonisation..$^{42}$ While this might be true in relation to specific policies, I suggest that looking at the broader colonial world affords us another reading. To many observers in the immediate post-war moment, empire was to play a vital role in European reconstruction. A popular neologism in the political vocabulary of the period - "Eurafrica" - conveyed the idea that Africa represented the natural and rightful solution to Europe's economic and demographic problems, for it provided a fertile terrain for investment and emigration. ${ }^{43}$ Here, the notion of "multiracial partnership" promised to deliver the benefits of "modern civilisation" to Africa without authorising Africans' anti-colonial aspirations or settler's blatant racial exclusivism. ${ }^{44}$ Yet by upholding the centrality of the white official, skilled labourer or settler as its driving force, multiracialism served to advance a conservative and racially defined model of social and economic change, essentially summarised in the phrase 'whites carrying the Africans along. ${ }^{45}$ To the proponents of white settlement, the settler carried the promise of material development and multiracial cooperation. In the political climate of the 1950s, the notion that Europeans could settle and thrive in Africa's multiracial societies was both "rational and convincing." 46

In this context, thus, Portugal's turn to white settlement and multiracialism as colonial policies becomes less an anachronism and more a political engagement with a rather contemporaneous predicament - and one that was shared by other European countries as well, albeit in different terms. At any rate, in the mid-century the problem of stepping up metropolitan migration to Africa became a political imperative: it was frequently featured in the press and carefully discussed at the National Assembly. A prominent figure in this regard, the Congressman Armando Cândido, was adamant in his call for state intervention: white settlement, he argued, was 'an imperative duty, a frontline necessity', because 'Angola and Mozambique are promises that our blood ought to fulfil' . ${ }^{47}$ "Europe", he goes on, "wants to resurface. Africa wants to advance. (...) No rivalry can surpass this argument of common salvation. (...) Eurafrica is not a new idea, but now it is urgent to follow it through' ${ }^{48}$ In an exposition delivered to the National Assembly and later published as a book, Cândido suggested a concerted state policy to carry out the "ethnic occupation" of the African provinces with metropolitan settlers. ${ }^{49}$ In this position, he was not alone.

Indeed, by the mid-century very few would vocally deny that white settlement to Africa was a national priority and, consequentially, should be translated into public policy. In the 1950s, development plans offered the budgetary resources to sponsor a new settlement programme..$^{50}$ In Southern Mozambique, 
a megaproject of "irrigation and colonization" of the Limpopo Valley directed major investment to infrastructures - particularly to dam the Limpopo River for irrigation and to expand the railway network to the Rhodesian border - but also allocated funds for rural colonisation, including expenses for white settlement. ${ }^{51}$ As Castelo has persuasively argued, the Limpopo scheme and parallel megaprojects - e.g. the Cunene settlement in Angola - encapsulate the contradictions and tensions underlying late Portuguese colonialism. On the one hand, they were a deliberate effort to modernise colonial economy through engineering and agronomical science. On the other hand, they were designed to foster an antiquated model of rural production based on the nuclear peasant family working small land units. In transferring Portugal's traditional structures and rural lifestyles to the tropics, these settlements (colonatos) embodied the regime's conservative politics and nationalist ideology better than other processes of social and economic change, such as industrialisation and urbanisation..$^{52}$

Surely, the picture was much different when seen from the point of view of the existing settler community. As Castelo has argued, even though a romanticised image of the poor "peasant settler" was disproportionately represented in colonial discourse, this group remained relatively marginal in relation to the global pattern of Portuguese migration and settlement to Africa. ${ }^{53}$ While potential settlers with little or no resources could apply for travel subsidies and join rural settlement programmes, the majority of the newcomers disembarking in Luanda and Lourenço Marques were voluntary migrants attracted by economic development and not allured by promises of agricultural labour and land ownership. Of these new arrivals, many would enlarge the ranks of colonial bureaucracy or join the mostly urban middle class working in services or commerce. During the late colonial period, the level of education and professional qualification of the settler population remained higher than the national average in the metropole. ${ }^{54}$ To this urban, educated and privileged settler community, a colonial project predicated on rurality, tradition and frugality was perhaps too obviously doomed to fail.

\section{Settlers of 'the lowest category': Poor whites and the multiracial myth}

On 3 August 1954, the leading Mozambican daily Notícias covered the arrival of a group of settlers to Lourenço Marques, aboard the vessel Império. Written by the novelist Guilherme de Melo, the article was peppered with lyric flavour and laudatory remarks. The first batch of peasants to settle in the Limpopo Valley, they were 'rude and simple', the men with their 'untied shirts' and the women in 'modest dresses'. In their simplicity, however, they embodied 'the soul of the people, the simple and crude soul of the eternal Portuguese people'. ${ }^{55}$ Later that year, Melo visited the settlement. He saw a 'rude but sane, humble but hospitable' people: a woman missing 'two or three teeth', and children in their 'bare feet and torn clothes'. There was something familiar at work here. After all, 
Melo pondered: 'this is the Portugal of the villages, [...] which is being built [on the African bush]'. The whole process should not be taken lightly. European settlement was a serious matter, and the entire enterprise was being closely supervised by engineers and technicians, whose offices were adjacent to the farmers' houses. In the future, it was expected, no supervision would be required, for the settlers would become 'accustomed to this new environment, $[\ldots]$ they will own their houses, their own oxen. The land will be theirs'. ${ }^{56}$

The odd juxtaposition of a romanticised portrayal of humble peasant life and a patriotic praise of what was essentially an effort in state-driven modernisation was fairly common in official and popular narratives of Lisbon's settlement programme. To another observer, the great transformation of the Limpopo Valley, made possible by 'a legion of technicians,' marked the dawn of a time of 'renewal and progress'. Yet irrigation systems and agricultural planning coexisted with ideals of home, family and catholic morality. If new buildings, the dam and the railway symbolised modernity, the church built in the settlement 'assert[ed] the spiritual nature of Portuguese colonization'. ${ }^{57}$ This type of narrative was rather common amongst the most conservative voices in the metropole - including Salazar himself - to whom Portuguese society and national identity were based on Catholic morality, on the idea of obedience of hierarchies, on traditional rurality and devotion to the land as epitomes of national virtue, and on the myth of noble poverty, i.e. the valourisation of modesty and resignation to poverty. ${ }^{58}$ The colonatos were designed to reproduce and propagate this set of conservative and traditionalist values in Portuguese Africa, while being at the same time a nationalist - and nationalising - gesture of evidently political implications.

Multiracialism was, too, a crucial trope underlying public debates on white settlement. In the Limpopo region, where white settlers were to work in the vicinity of their African counterparts, policy-makers hoped that contact and collaboration would further multiracial conviviality and serve to diffuse Salazarist values. As an official pamphlet put it,

we want (...) white families from the metropole (...) to grow roots to the land, to own the land where they work, exercising here the traditional virtues of the Portuguese peasant - tenacity, modesty, commitment to work and love to the family, therefore serving as an example to their African brothers. ${ }^{59}$

As Castelo has argued, the schemes of rural colonisation relied on the false assumption that the white peasantry would operate as exemplary models to be emulated by the "erratic" African masses, thus leading to increased productivity and social assimilation into the national body. ${ }^{60}$ At work here was the Freyrian notion that the Portuguese settler possessed the innate ability to cooperate with African populations and thrive in the tropical climate, regardless of their level of education, technical training or familiarity with modern methods of agricultural production. Political debate on this matter often depended on problematic 
stereotypes and a rather idealised image of the settler. As a Congressman told the National Assembly in 1952: 'the Portuguese peasant, holder of racial virtues, will carry to the bush the qualities of work, persistence, affection for the land, sobriety and candour in behaviour, frugality, all of which will certainly have an effect on the education of the black Portuguese'. ${ }^{61}$ Poverty was not necessarily detrimental to the civilising mission. Rather, a common assumption in Portuguese colonial thinking was that lower-class settlers were more prone to co-exist with Africans on cordial terms, given their relative proximity in the civilisational and social scale. ${ }^{62}$

Unsurprisingly, the picture was much different when seen from the standpoint of settler society itself. Both colonial officials and so-called naturais (i.e. second generation, Mozambique-born, whites) ${ }^{63}$ expressed their reservations, when not open disapproval, about Lisbon's settlement policy. Criticism was found at all levels of society and civil service for various reasons. Some of the detractors voiced their grievances to members of diplomatic missions. After a visit to the Limpopo area, the South African Consul reported that the existing Portuguese community feared that 'the semi-literate peasants [would] have no conception of the conditions and would be appalled by the reality'. Consequentially, local residents suspected, the newcomers would drift 'back to the towns, where their illiteracy would make them unemployable except on "kaffir work". ${ }^{64}$ The governor-general of Mozambique himself, Major Pinto Teixeira, showed dissatisfaction with the course of action set up by the metropolises. As he told the Consul, the "theorists" sitting in Portugal were "silly fools" with no knowledge of African realities. ${ }^{65}$ According to another diplomat, the US Consul, Teixeira shared the criticism of 'the more intelligent members of the local population' when he publicly stated that 'it is necessary not only to prepare the colony for the colonists, but the colonists for the colony' ${ }^{66}$ Interestingly, Teixeira urged Trigo de Morais, the main engineer behind the Limpopo scheme, to conduct a study visit to analogous rural settlements in South Africa, for the purpose of 'inject[ing] a little more realism into the somewhat idealistic plans for the Limpopo Valley'. ${ }^{67}$ The issue of settler selection and preparation was also openly discussed in the press. Oliveira Boléo, an intellectual who wrote several opinion pieces on the issue of white settlement, argued that the 'bar [needed] to be high' or failure and deflection would be inevitable. He feared that 'in a decade [we might] see thousands of settlers wandering the streets [of the capital], knocking on the doors, telling the story of their odyssey in this land'. ${ }^{68}$

Besides misgivings about the feasibility of the project itself, various observers also raised concerns about the possible effects the recent arrivals would have on race relations. While one of the goals of the Limpopo project was to promote multiracial contact by planning for the settlement of African farmers along their European peers, African families were introduced in the scheme progressively, in small numbers, and only from 1957 onwards. ${ }^{69}$ Still, much speculation existed about it from the offset. For instance, the US Consul noted it was 'thoughtprovoking [...] to come upon a community in Southern Africa where white men are driving bullock carts along with black men'. This peculiar situation, 
he thought, could provoke a 'significant although unascertainable impression' on the African. ${ }^{70}$ According to a colonial official placed in the area, 'white settlers [could] end up in the same position in life as the natives'. As said official told the Consul, the 'intimate association of white and black [could] destroy the "reasonable barriers" that exist'. ${ }^{71}$ Poor settlers, in this view, threatened to disrupt the racial hierarchies of colonial society. This anxiety over the possibility of racial decay was also articulated in the press. An editorial claimed that 'the life of the white men should never mirror that of a black man, for the first is expected to orient, to teach, to rule'. White unemployment and poverty could damage the 'prestige of the European', with negative results as far as the 'respect and obedience of the native' was concerned. ${ }^{72}$

Interestingly, to other observers the poor white problem was dangerous for the opposite reason, because it could aggravate racial antagonisms by creating colour bars where (presumably) none existed. While the official discourse boasted the innate non-racist attitude of the Portuguese people, confidential correspondence and news articles reveal a different picture altogether, in which poor whites were disproportionally given credit for colonial racism. In a detailed report on the social colour bar in Mozambique, for instance, the US Consul argued that settlers of 'the lowest category, such as domestic workers and manual laborers, are even more prejudiced against Blacks than better-class Portuguese'. It was not at all uncommon, the Consul claimed, to witness a white 'who cannot read or write' mistreating an African 'who is cleaner, smarter, and better educated' ${ }^{73}$ The Portuguese anthropologist Jorge Dias painted a similar picture. Dias is an interesting source because he represents a younger generation of thinkers for whom the theory and practice of colonialism needed significant reform. In the 1950s, he was sent to Portuguese Africa on several research missions to study the problem of "ethnic minorities" as part of a larger movement to recalibrate colonial governance by a closer engagement with applied social sciences. ${ }^{74}$ As a result of his travels, he reported on the social life of the settler community in both urban and rural settings. His conclusions were less than reassuring. In a visit to the Limpopo Valley in 1960, he was perturbed to find white farmers terribly ill-prepared for local conditions, including by the sight of youngsters farming the land barefooted or drinking untreated water because they had seen 'the Africans do the same'.$^{75}$ To Dias, 'some whites give the impression of being more primitive than many Africans' ${ }^{76}$ Yet despite 'their misery and difficulties in adaptation', some settlers harboured unrealistic pretentions, such as a husband who 'had promised his wife to find her a Black servant to wash her feet'. ${ }^{77}$ Going against the grain of dominant colonial thinking, Dias argued that 'we cannot count simply on the virtues of our people, [but] we need to select and prepare them. ${ }^{.78}$ Perhaps more importantly, it was imperative to "educate" settlers so "they do not feel they are superior merely by the virtue of being white'. ${ }^{79}$

Despite these recommendations, two years later the conditions in the Limpopo Valley deteriorated even further. A government report on the uplifting of the African population in the region singled out the white farmer as a source 
of racial antagonism. Contrary to what was expected, many of the new settlers did not get along with their African peers at all. Quoting from a police report on the quarrels between Europeans and Africans in the settlement, the reporting officer described the poor white in rather unflattering terms: 'approximately 70\% [of our settlers are] wicked and lazy, which causes constant hostility between them and the natives' ${ }^{80}$ The list of reprehensible, if not criminal, behaviour was long, and included trespassing on the property of African farmers, grabbing their chickens, invading their crops, reaping their corn, stealing their watermelons and pumpkins, mistreating their cows and threatening them with violence in case they reported any such offences. 'All these acts', the rapporteur concluded, 'stimulate the natives' dislike of the European'. ${ }^{81}$ In the Limpopo Valley, daily life was tainted with 'heated arguments, obscene insults, threats, and beatings, and things are worsening'. ${ }^{82}$ Local opinion was that the metropole was to blame, due to the lack of rigorous vetting of potential settlers. In fact, 'rumour had it' that settler recruitment was managed by priests and council administrators in Portugal, who were eager 'to get rid of their bad elements and for this reason convince them to come to Africa' ${ }^{83}$ To avoid further escalation of racial tensions, the reporting officer requested more policing and discipline, to be imposed energetically if necessary. The police, he advised, 'should not follow the same methods observed in a civilized context'. In the Limpopo settlement, the state needed to intervene without reservations, to 'abuse its authority' in face of the 'ignorant settler' ${ }^{84}$

The situation in the urban centres was not necessarily better. Rural settlers who could not adapt to the harsh conditions abandoned the colonatos for Portugal if they could afford it or migrated to the capital or even South Africa. ${ }^{85}$ Particularly in Lourenço Marques, they joined a growing population of unemployed whites. To be sure, the problem of settler unemployment had haunted Mozambique's economy seasonally, since at least the early $1950 \mathrm{~s} .{ }^{86}$ As the decade progressed, it served to fuel the growing local criticism of Portugal's settlement policy. Jorge Jardim, a prominent businessman and Mozambique's delegate to the National Assembly, dismissed rural colonisation as a both expensive and ineffective venture, while defending instead the industrialisation of Mozambican economy coupled with the facilitation of voluntary migration of skilled labour. ${ }^{87}$ Mozambique's Legislative Council, too, called for a more rigorous control of immigration based on the aptitude of settlers. ${ }^{88}$ Only then, Gonçalo de Mesquitela pointed out, would Mozambique 'receive the last inapt [of settlers], as we cannot expect to receive the most apt' ${ }^{89}$ Another Council member, Dias Ferreira, opposed an "open door" settlement policy, claiming this would result in a 'factory of unemployment' for which the local government would have to pay. ${ }^{90}$ In conclusion, the Council favoured larger powers to be given to the local Mozambican government in the areas of immigration and settlement while opposing schemes of rural colonisation. ${ }^{91}$

The late 1950s was also ripe for a small but rather prominent group of settlers, frequently naturais, to voice their opposition to the metropolitan government for what they regarded as an exploitation of Mozambique's resources 
without much in return. This local settler opposition was a diverse but not formally organised political force. It included liberal professionals, such as lawyers, and politically-minded members of the businesses community. Their grievances had several causes: from the conservative politics of the regime to the economic stronghold it imposed on the province and the lack of local autonomy and decision-making power. ${ }^{92}$ Lisbon's settlement policy was another critical issue through which this local elite expressed their political dissent, including by criticising it as a social liability and an imprudent spending of public resources. In May 1961, an anti-government manifesto distributed in Beira and Lourenço Marques openly targeted a policy that was producing in Mozambique 'a poverty similar to that of the metropole'. The signatories condemned Lisbon's record of indifference, which for many years had allowed voluntary Portuguese emigrants to go, 'like human ants', to Brazil, Venezuela and other destinations. After years of this 'waste of manpower, which other more capable countries put to use', the Lisbon government was now 'adopting, although too late, its colonization scheme [...] which have destined some of the settlers $a b$ inition to an almost certain life of misery'. ${ }^{93}$

Despite the local criticism, the settlement policy survived way into the 1960s, even though the rate of new arrivals decreased if compared to the previous decade. ${ }^{94}$ If anything else, the early 1960 s saw a push to the intensification of existing policy. As part of a broader legislative package of reforms, Lisbon created Settlement Boards (Juntas de Povoamento) to specifically manage white settlement in Mozambique and Angola, while establishing the free circulation of people and goods between Portugal and its overseas provinces. The relaxation of immigration procedures was intended to promote the unity between metropole and overseas territories by facilitating voluntary white settlement. Certain restrictions on settler mobility, such as the presentation of an invitation letter and proof of employment, were lifted. These measures did not sit well in local circles. In June 1962, editorials published in the newspaper Notícias bitterly criticised the 'propagandists of illusion' enticing 'poor, uneducated and ignorant agricultural workers to come to the "land of opportunity" without the slightest knowledge or assurance of employment'. ${ }^{95}$ In an open criticism of Lisbon's priorities, the editors stressed that 'there are no conditions for work, because neither industry, nor agriculture, [. . .] nor anything have been developed sufficiently'. ${ }^{96}$

While the problems of unemployment and white poverty were windows into what many settlers saw as the injustice of the imperial relationship itself, other observers were more interested in how economic competition for unskilled and poorly paid jobs was deteriorating the state of race relations. As the paper Notícias da Beira reported, 'the formation of a white proletariat is not [...] an admirable manifestation of absence of race prejudice, neither does it encourage, in the African, the sentiment of equality before the European'. Rather, because poor whites now flooded the labour market to compete for low skilled jobs with the African with no instruction, 'the doors are closing [for the latter]' ${ }^{97}$ Therefore, by limiting the employment opportunities available to Africans, 
the news article cautioned, "we may fall into a racial segregation that is [. . ] the opposite of what our vocation dictates'. ${ }^{98}$ While economic competition in urban settings was not a particularly new problem - and had been on the rise since the early $1950 \mathrm{~s}$ - it became increasingly entangled to colonial concerns about the state of seemingly deteriorating race relations.

In fact, in 1956, two years after the launch of the Limpopo scheme, Jorge Dias described with disquiet the racist behaviour within the settler community in Lourenço Marques, in what he saw as a dangerous disregard for the (presumably) traditional non-racist attitude of the Portuguese people. Yet to him this unfortunate situation did not result from the reality of colonialism itself. Rather, he was more inclined to trace the origins of colonial racism to the influence that apartheid South Africa exerted on white settlers. The poor, individuals with 'no culture or half-cultured', were an easy prey to apartheid's appeal. Dias's reading is so vivid that I will quote it at length:

Many of the Portuguese of Mozambique, [. . . because they drink whiskey, drive cars, know how to say a few things in English and have acquired the mockery of a culture, translated in the acquisition of [material goods] to which they were not used, feel an inferiority complex in relation to their neighbours [in South Africa]. [...] Placed then in the position of admirers of their neighbours, vaguely displeased with their own economic power when compared with the latter's, and convinced of their own superiority in relation to the metropole, where people of their class have a clearly inferior standard of living; these third-class Portuguese - despite their undeniable virtues - seek to imitate these neighbours. [. . .] Well, if their neighbours, in their eyes so civilized, consider the African to be inferior, it would be unreasonable to act otherwise. [. . . This general trend opens the gate to various acts of violence and rudeness by individuals with no scruples, who, once in Africa, think they are an elite by the simple fact that they are white. [...] Some of them, who in the metropole were in the lowest social rank, hold on greedily to the opportunity of upward mobility and think that in order to achieve this end they must demean the Africans, by brutalizing them at times, both morally and physically. ${ }^{99}$

In my view, the elitist bias of his remarks evidence how class inequality within white settler society informed understandings of race relations and was crucial in defining what counted as respectable, civilised behaviour. This opinion was not uncommon amongst an educated and self-proclaimed progressive class of government officials and settlers, who blamed the state of racial unrest on their poorer countrymen. Because Portuguese late colonialism was so strongly predicated on the claim to multiracialism as a civilising virtue, cordial multiracial relations were celebrated in public discourse, the press, and official functions. The type of racist behaviour associated with the lower classes was deemed as uncivilised, inconvenient and in need of reformation. The notion that poor settlers were particularly racist persisted for years to come. But what is interesting 
about Dias's observations is that he repositioned the problem of colonial racism and white settlement in a comparative frame, and explicitly relates it to apartheid South Africa. While Dias was concerned with the cultural, and as a result political, influence of apartheid on the settlers' mindset, other observers pointed out the very material, tangible shadows of South African presence in Mozambique, from economic dominance to the tourist trade. While in Mozambique regional tourism had been a recurrent topic of public debate for decades, in the 1960s it assumed greater proportions, as the industry grew steadily to represent a significant economic activity. ${ }^{100}$ At a time when multiracialism was being celebrated as a benign colonial ideology, South African tourists were accused of bringing the colour bar with them.

That Portuguese settler colonialism existed in the shadows of apartheid was a claim that gained much appeal on the eve of decolonisation. Already in the late 1950s, the American anthropologist Marvin Harris, who had spent a year in Mozambique and interviewed dozens of Africans, published what was, at the time, one of the only first-hand critiques of Portuguese colonialism. Going against the official narrative, Harris described an 'apartheid-like system of separate and unequal treatment more severe in many respects than that which exists within the Union of South Africa. ${ }^{101}$ Liberation movements, too, deployed similar arguments and analogies in their struggle to expose the evils of Lisbon's rule. As the Angolan nationalist João Cabral put it, the 'so-called anti-racialist policy' had given way to a 'classic colonialist policy' based on massive white settlement. As poor whites were now working on positions earlier occupied by assimilated Africans, Cabral argued, 'colour discrimination was taking more obvious apartheid forms'. ${ }^{102}$ Likewise, when the prominent Mozambican nationalist - and later president of FRELIMO ${ }^{103}$ - Eduardo Mondlane spoke to the United Nations in 1962 as a petitioner, he stated that Portuguese settlers 'had exactly the same attitude toward Negroes as the South Africans had'. ${ }^{104}$ Two years later, as the clash of political forces accentuated and Mozambique, as much as the rest of Southern Africa, descended into a liberation war, the entanglements between Portuguese settler society and regional white rule became perhaps too obvious to ignore. One decade later, an article by the white oppositionist António de Figueiredo published in the Anti-Apartheid News denounced that Lisbon's multiracialism 'means white domination'. ${ }^{105}$ In the long run, settler colonialism had simply imploded the multiracial myth.

\section{Conclusion}

The transfer of metropolitan peasants to Africa was a move to secure colonial sovereignty amidst what was perceived as a particularly "troubled time" (that is, the eve of decolonisation). Yet this shift to transform Mozambique into a settler colonial space necessarily strengthened social and political entanglements with the other settler states in Southern Africa in ways that often escaped and challenged metropolitan control. The unrealistic expectations that the settler, however unskilled or unprepared, could bring economic development, civilisation 
and multiracial conviviality to Africa were frustrated by the rapid deterioration of race relations and failure of settlement projects. The contrast between a state initiative centred on small-scale family farming and poor settlers, on the one hand, and the aspirations of a local settler elite, on the other, only served to emphasise the politically conservative and economically deficient nature of Lisbon's late colonial rule. Local oppositionists were aware of this contradiction and criticised Lisbon-based policy-makers for forcing on Mozambique the same poverty experienced in the metropole. At the same time, the allure of South Africa was not limited to its booming economy and promises of settler comfort. Here, the disquieting notion that racial prejudices could cross the border and come to shape the racial attitudes of the Portuguese settler community was common. In fact, to some observers, Mozambique 'had been infected by South Africa. ${ }^{106}$ Colonial officials were unable to perceive racism as a defining attribute of settler culture, but frequently singled out poor whites as "bad apples" in an otherwise healthy and colourful fruit bowl. Despite Lisbon's insistence on producing "Portugals in Africa", the poor, uneducated settler remained perpetually out of place in a system where race and civilisation were supposed to overlap. They were whites, but not quite.

\section{Notes}

1 On the political views of the white community in Angola, including forms of political organisation, see: Pimenta, Brancos de Angola; Pimenta, 'Angola's Whites'; Pimenta, Angola; Pimenta, 'Angola's Euro-African Nationalism'. On the social composition and racial attitudes of the white population in Angola, see Bender, Angola Under the Portuguese; Castelo, Passagens para a África.

2 Castelo, Passagens para a África; Penvenne, 'Settling Against the Tide'. Another significant, although less detailed, study is Middlemas, 'Twentieth Century White Society in Mozambique'. See also Zamparoni, 'Entre Narros \& Mulungos'.

3 For instance, the 1950 Census registered 78,826 whites in Angola compared to 48,200 in Mozambique. In 1960, this number jumped to 172,529 compared to 97,200 . See Penvenne, 'Settling against the Tide', 86.

4 There are no definitive figures for the number of dead in the March 1961 revolts, but most accounts vary from 200 to 1,200 whites and up to 8,000 Africans, 3,000 of whom were Bakongo and associated to nationalist movements. For a recent account on figures, see Mateus and Mateus, Angola 61 Guerra Colonial, 129.

5 To be sure, this is not to say that colonial massacres did not happen in Mozambique in the late colonial period. Hundreds of Africans were reportedly killed in Mueda, in 1959, and Wiriyamu, in 1972.

6 Pimenta has written extensively about FUA (Frente de Unidade Angolana - Front of Angolan Unity), an independent movement formed mostly by white settlers and, to a lesser extent, mestiços. See Pimenta, Angola.

7 Castelo, Passagens para a África, 380-381; Castelo, 'Colonial Migration', 122-123; Chabal, A History of Postcolonial Lusophone Africa, 111-112.

8 For groundbreaking considerations on circuits, networks, and transnationalism more generally in histories of race and empire, see Stoler and Cooper, 'Between Metropole and Colony'; Stoler, 'Tense and Tender Ties'; Cooper, Colonialism in Question; Stoler, 'Racial Histories and Their Regimes of Truth'; Lake and Reynolds, Drawing the Global Colour Line; Jerónimo and Monteiro, Internationalism, Imperialism and the Formation of the Contemporary World. 
9 Veracini, 'Settler Colonialism', 313.

10 The notable exception, which purposefully includes a more diverse plethora of cases, is Elkins and Pederson, Settler Colonialism in the Twentieth Century.

11 For recent explorations of this literature, see Pimenta, 'Colonialismo Demográfico Português em Angola'; Choi, Decolonization and the French of Algeria; Barclay, Chopin and Evans, 'Settler Colonialism and French Algeria'.

12 On the 'transcolonial' as a productive historical lens, see Ghosh and Kennedy, Decentering Empire.

13 Veracini, Settler Colonialism; Veracini, 'On Settlerness'.

14 Veracini, 'On Settlerness', 3.

15 Castelo, "'O 'branco do mato de Lisboa"' is the only available study specifically addressing the poor white question in Mozambique. In his review of the literature available in 2010, Pimenta points out that 'in spite of existing studies, a history of the Portuguese settler, properly speaking, does not exist.' Pimenta, 'Perspectivas da historiografia Colonial Portuguesa', 153.

16 For instance, when in 1957 the National Assembly reviewed the public budget for previous years, the expenses relating to the Development Plan in Mozambique were registered as follows: from a total of 1,096,834 contos invested in the country, 744,452 (around 67\%) were dedicated to the Limpopo Railway, 54,034 to the Vila Luísa de Manhiça Railway, 29,999 to the Port of Nacala, 21,067 to the Lourenço Marques Airport, and 12,732 to other aerodromes. See República Portuguesa, Secretaria da Assembleia Nacional, Diário das Sessões, Sessão Número 184, 8 March 1957, 320-391.

17 Rodrigues, 'Plano de Fomento do Ultramar', 65.

18 Ibid., 66.

19 For a pan-European view, see Buettner, Europe After Empire.

20 Low and Lonsdale, 'Introduction'.

21 On the issue of imperial revivals, see Lynn, The British Empire in the 1950s; Butler, Britain and Empire.

22 See Jerônimo and Pinto, 'A Modernizing Empire?'; Castelo et al., 'Introdução'.

23 Jerônimo and Pinto, 'A Modernizing Empire?’ 55-56.

24 Ibid., 59-64.

25 On colonial scientific research, see Castelo, 'Scientific Research and Portuguese Colonial Policy', 391-408; Martins and Albina, Viagens e Missões Científicas nos Trópicos. On colonial development, see Castelo, 'Reproducing Portuguese Villages'; Castelo, 'Developing "Portuguese Africa”'. On Salazar's emigration policy, see Galvanese, 'Os discursos sobre a emigração portuguesa'; Pereira, 'La Dictature Salazariste'.

26 Rodrigues, 'Plano de Fomento do Ultramar', 65.

27 Freyre, Casa grande \& Senzala.

28 Freyre, O Luso e o Trópico.

29 On racial thinking in Portugal until the mid-century, see Thomaz, Ecos do Atlantico Sul; Thomaz, "O Bom Povo Português"'; Matos, The Colours of the Empire; Cleminson, Catholicism, Race and Empire.

30 Castelo, O modo português de estar no mundo; Léonard, 'Salazarisme et lusotropicalisme', 211-226; Thomaz, 'Tigres de Papel'.

31 Castelo, 'Prefácio à presente edição', 17.

32 Bender, Angola Under the Portuguese; Cabaço, Moçambique; Neto, 'Ideologias, Contradições e Mistificações'.

33 Boxer, Race Relations in the Portuguese Colonial Empire; Hammond, 'Race Attitudes and Policies', 205-216.

34 For a convincing comparative analysis between the Portuguese and the British cases, see Bender, Angola Under the Portuguese. On colonial ideas of miscegenation, see Cleminson, Catholicism, Race and Empire; Vale de Almeida, 'Anthropology and Ethnology', 435-438; Vale de Almeida, 'Longing for Oneself'. 
35 On arguments against white settlement in the tropics circulating in this period, see Castelo, Passagens para a África, 49-54. On the historical constitution of Angola and Mozambique as settler colonies, see Meneses and Gomes 'Regressos?'.

36 The white population of Angola grew steadily in the first decades of the century, from 9,198 in 1900 to 20,700 in 1920 to 44,083 in 1930. In Mozambique, it grew from 2,064 in 1900 (excluding the area under the Administration of the Mozambique Company) to 11,000 in 1920 to 27,438 in 1940. See Castelo, Passagens para a África, 59; Pimenta, Angola's Euro-African Nationalism, 196; Penvenne, A History of African Labour, 421.

37 Projects on the colonisation of Southern Mozambique, for instance, had been in preparation since the 1920s but failed to materialise until the 1950s. See Lopes, 'Colonato do Limpopo'. For an excellent assessment of the settlement policy up until the midtwentieth century, see Gonçalves, 'Of Peasants and Settlers'; Bender, Angola Under the Portuguese, 97-104; Castelo, Passagens para a África, 43-106; Penvenne, African Workers, 97-100.

38 Gonçalves, 'Of Peasants and Settlers', 169-172.

39 Castelo, 'Colonial Migration', 111.

40 Belich, Replenishing the Earth, 153-164.

41 República Portuguesa, Secretaria da Assembleia Nacional, Diário das Sessões, VI Legislatura, Sessão Número 203, 679.

42 See Castelo, Passagens para a África; Penvenne, 'Settling Against the Tide'.

43 Hansen and Jonsson, 'Demographic Colonialism', 261-276; Hansen and Jonsson, Eurafrica.

44 Soske, 'The Impossible Concept'; Dixon, 'The Multiracial Myth', 61-65.

45 Tischler, Light and Power, 221.

46 Hansen and Jonsson, 'Demographic Colonialism', 272.

47 Speech delivered to the National Assembly on 10 December 1952. República Portuguesa, Secretaria da Assembleia Nacional, Diário das Sessões, VI Legislatura, Sessão Número 178, 290.

48 Ibid., 291.

49 Cândido, O problema dos excedentes demográficos, 210-215.

50 Castelo, 'Colonial Migration', 110-112.

51 The First Development Plan allocated 236,580 contos to the River Dam project and 744,452 contos for the construction of the Limpopo Railway, which ran until the Rhodesian border. Up until 1961, 324,200 contos had been invested in colonisation, of which $45,9 \%$ was dedicated to the installation of settlers and $8,1 \%$ to their transportation, while $25,5 \%$ was invested in collective infrastructure for the rural settlements. See AHD, 6569, 'Irrigação e Colonização do Limpopo', Brochure sent from Trigo de Morais to Cabinet of Political Affairs, 17 May 1961.

52 Castelo, 'Reproducing Portuguese Villages in Africa', 273-274; Gonçalves, 'Of Peasants and Settlers', 177-178.

53 Castelo, 'O 'branco do mato de Lisboa', 27-28.

54 Ibid., 30.

55 'Chegaram os primeiros colonos para o Limpopo', Notícias, 3 August 1954.

56 'Ergue-se na terra negra do Limpopo uma aldeia tipicamente metropolitana', Notícias, 19 November 1954.

57 Article published in the Mozambican newspaper Guardian and reprinted in Santos, 'Aproveitamento do Vale do Limpopo', 190.

58 Adinolfi and Costa Pinto, 'Salazar's "New State", 170-171; Rosas, 'O salazarismo e o homem novo'.

59 AHD, 6569, 'Irrigação e Colonização do Limpopo', Brochure sent from Trigo de Morais to Cabinet of Political Affairs, 17 May 1961.

60 Castelo, 'Reproducing Portuguese Villages in Africa', 97.

61 Speech delivered to the National Assembly on 6 December 1952. República Portuguesa, Secretaria da Assembleia Nacional, Diário das Sessões,VI Legislatura, Sessão Número 175, 201. 
62 Bender, Angola Under the Portuguese, 225.

63 Naturais ("naturals of"), in reference to their Mozambican roots.

64 NASA, BTS, 1/14/6-239, 'Report on a visit to the Railway Extension and Irrigation at Guija in the Limpopo Valley, 24-26 June 1953', from South African Consulate in Lourenço Marques to Department of External Affairs, 19 July 1953.

65 NASA, BTS, 1/14/6-239, Confidential Despatch 46/1, from South African Consulate in Lourenço Marques to the Secretary for External Affairs, 6 July 1953.

66 National Archives and Records Administration II, Washington, DC, USA (hereafter NARA), Record Group (RG) 59, Box 3718, 'Survey of Local Attitudes', Foreign Service Despatch no 188, From American Consulate in Lourenço Marques to Department of State, 6 May 1952.

67 NASA, BTS, 1/14/6-239, Confidential Despatch 45/2/2, from South African Consulate in Lourenço Marques to the Secretary for External Affairs, 30 November 1953.

68 Boléo, 'A propósito do Povoamento do Vale do Limpopo', Notícias, 29 September 1952.

69 As Matine has argued, the late gesture of introducing African farmers in the Limpopo scheme was pursued mostly for its propaganda value, precisely to discredit any accusation that the programme was being carried out on racially discriminatory grounds.

70 NARA II, RG59, Box 2586, 'Visit to the Limpopo Scheme', Foreign Service Dispatch no. 279, from American Consulate in Lourenço Marques to the Department of State, 28 June 1961.

71 NARA II, RG 59, Box 5041, 'Limpopo Dam and Irrigation Project - Mozambique', Confidential Section, Foreign Service Despatch no 88, 30 November 1953.

72 'Fixação de Brancos no Ultramar', Boletim Geral das Colónias, 28(1953), 113.

73 NARA II, RG 59, Box 4628, 'Social Apartheid in Mozambique', Foreign Service Despatch no 117, American Consulate in Lourenço Marques to the Department of State, 16 December 1958.

74 More on this context, see Castelo, 'Scientific Research'; Leal, Etnografias Portuguesas; Pereira, 'Conhecer para Dominar'.

75 Dias, Relatório da Campanha de 1960, 23.

76 Ibid.

77 Ibid.

78 Ibid.

79 Ibid.

80 AHD/MU/GM/GNP/060/Pt. 1, Confidential, 'Relatórios sobre a elevação da população nativa dos Governos dos Distritos de Gaza, Inhambane, Manica e Sofala, Zambézia, Tete, Moçambique, Cabo Delgado e Niassa, referents ao 1o. trimestre do corrente ano', Informação no. 45/1/CM/962, 20 December 1962, 5.

81 Ibid.

82 Ibid.

83 Ibid., 6.

84 Ibid., 7.

85 It is estimated that $8,3 \%$ of settlers abandoned colonato in the first 10 years. See Castelo, 'O 'branco do mato de Lisboa', 46-47.

86 Penvenne, African Workers, 101-102.

87 República Portuguesa, Secretaria da Assembleia Nacional, Diário das Sessões, VI Legislatura, Sessão Número 145, 926.

88 'O povoamento de Moçambique: de novo o debate, mas quanto a execução?' Notícias da Beira, 22 April 1959.

89 Ibid.

90 Ibid.

91 Ibid.

92 US Consular Files are particularly rich in regard to the activities of this opposition, as many of its members voiced their criticism to the US Consulate in Lourenço Marques. 
93 NARA II, RG 59, Box 1818, 'Anti-government Manifesto Circulated in Beira and Lourenço Marques', Full text annexed to Foreign Service Despatch no. 238, from American Consulate in Lourenço Marques to Department of State, 9 May 1961.

94 Castelo, 'Colonial Migration'.

95 NARA II, RG 59, Box 2586, 'Labor - Sharp Increase in European Unemployment in Mozambique; March of Unemployed to City Hall', Airgram A-28, from American Consulate in Lourenço Marques to Department of State, 23 July 1962.

96 Ibid.

97 'Realidades da vida portuguesa', Notícias da Beira, 4 November 1961.

98 Ibid.

99 Ibid., 8.

100 By the early 1970s, white South Africans and Rhodesians represented nearly $75 \%$ of the foreign clientele, see Coelho, 'Elementos Estatísticos', 145-161, 158.

101 Harris, 'Portugal's African Wards', 6.

102 Cabral, 'A Portuguese Letter', 60-62.

103 FRELIMO was formed in 1962 and resulted from a fusion of two other nationalist organisations' operation in Dar-es-Salaam: National Democratic Union of Mozambique (União Democrática Nacional de Moçambique - UDENAMO), Mozambique African National Union (MANU).

104 NASA, BTS/1/14/6-7, 'Committee Continues Questioning of Petitioner from Mozambique', United Nations Press Release, 10 April 1962.

105 Figueiredo, 'Portuguese "Multi-racialism" Means White Domination', Anti-Apartheid News, 10 March 1972. Figueiredo was a white oppositionist who had personally helped Marvin Harris to gather information for his pamphlet on Mozambique. After being harassed by the security police, he eventually went into exile in London.

106 NARA II, RG 59, Box 4628, 'Social Apartheid in Mozambique', Foreign Service Despatch no 117, American Consulate in Lourenço Marques to the Department of State, 16 December 1958. 


\section{6 "Village Portugal" in Africa \\ Discourses of differentiation \\ and hierarchisation of settlers, 1950s-1974}

Clándia Castelo

\section{Introduction}

Much of colonial and imperial historiography appearing soon after decolonisation, either implicitly or explicitly considered settlers - that is, people from the metropole who made their homes in the colonies as their own country - as in loco agents of colonialism and did not acknowledge their relevance as objects of study. The analysis of the structures and effects of the colonial system was privileged, as well as resistance and the national liberation struggles. In the late 1980s, however, a group of historians and anthropologists set out to explore new frontiers and themes of research that could challenge the reductive dichotomy between colonisers and colonised. ${ }^{2}$ They argued that approaching these two groups in a homogeneous, stereotyped and diametrically opposed manner did not offer much insight into the colonial situation, since it concealed the ethnic, social and cultural diversity in colonial contexts; the internal heterogeneity of each of those categories; and possible zones of contact and permeability. The idea that these categories were not immanent or static but constructed by colonial power and reused by anticolonial narratives gained ground. ${ }^{3}$

Taking the literature on settler colonialism into account, this chapter presents a case study of Portuguese colonial experience in Africa. It focuses on white settlers who were sent by the Portuguese Estado Novo, the dictatorial, conservative and colonialist regime that prevailed in Portugal between 1933 and 1974, to state-sponsored rural settlements established in Angola (Cela and Cunene) and Mozambique (Limpopo) in the 1950s as archetypes of Portugal in Africa. These settlers were only a tiny portion of Angola and Mozambique's settler societies and were not representative of the "average" Portuguese colonist. ${ }^{4}$ Although Portuguese citizens, native from the metropole, and "civilised" and Catholic, they were poor and illiterate, moved to rural areas and were supposed to work the land by themselves. Their over-representation, both visually and descriptively, in the press and in the propaganda, often connected with the discourse about the exceptionality of Portuguese colonisation vis-à-vis that of the British and the French is intriguing and calls for historical inquiry. This chapter intends to add to a more comprehensive approach to the white societies in "Portuguese Africa", proving its economic, social and cultural internal 
heterogeneity. This contributes to setting up a comparative framework between settler societies in Southern Africa.

I will seek to identify, compare and interpret the different ways of seeing, making visible and understanding the people who settled in the Cela, Cunene and Limpopo colonatos, as well as their experience of living and working in these settings. For this, I employ a variety of sources: official discourses, newspapers and propaganda publications, scientific production, self-representations, and perceptions of other settlers and of African people around the colonatos. ${ }^{5}$ I open with a brief contextual discussion on the question of planned agricultural colonisation since the late nineteenth century, before proceeding to focus on the 1950s "ideal" colonatos as evidence of the contradictions and dilemmas of the late Portuguese settler societies in Africa.

\section{Planned agricultural colonisation: background views, failures and impasses}

The establishment of white Portuguese settlers in "Portuguese Africa" was strongly influenced by environmental, economic, social and symbolic factors, and even by legal obstacles. ${ }^{6}$ In terms of effective political action, there is not much to note about state-directed white settlement in Angola and Mozambique until the mid-twentieth century. Except for the creation of Moçamedes (1849-1850) with Portuguese immigrants from Pernambuco, Brazil, and of Lubango (1884-1885) with settlers from Madeira and Trás-os-Montes, both in the south of Angola, there were only occasional efforts to create agricultural colonies and to provide free transportation for a few hundred settlers. After the sending of hundreds of settlers to Angola and Mozambique in 1891 (a hasty response to the British Ultimatum), local colonial governors severely criticised the settlement policy conceived in Lisbon without any knowledge of local realities; and complained about the burden of poor and unskilled migrants to the Public Treasury in the respective colonies, since the government was forced to repatriate settlers to Portugal on several occasions.

The physician Manuel Ferreira Ribeiro (1839-1917) and the naval physician and naturalist explorer José Pereira do Nascimento (1860-1913) were active supporters of transplanting whites from the metropole to the African colonies based on the scientific study of Portuguese Africa (climate, geography, vegetation, etc.) and the acclimatisation of settlers to tropical spaces, to guarantee their survival and reproduction without the much-feared racial degeneration. Both wrote about the places where Europeans could live without risks for their health, provided they followed the recommended hygiene habits. ${ }^{7}$

Regardless of the scientific conclusions of these two doctors, Africa continued to be seen as a dangerous and inappropriate place for the permanent settlement of Europeans. Due to the inhospitable climate and deadly diseases, it was a fate only for the degredados (deportees), the condemned and the perceived failures of the metropole. ${ }^{8}$ At the same time, it continued to be argued that the European could not adapt to the tropics without losing their civilised 
habits and moral virtues, and that the European family would hardly go beyond the second generation without losing these. ${ }^{9}$ Irrespective of the possibilities of acclimatisation, prominent Republican politicians considered that it made no sense to settle illiterate and poor Portuguese migrants, to exploit the land on their own. ${ }^{10}$ Given the existence of an abundant and cheap African labour force to run the essentially agricultural economies of Angola and Mozambique, only Portuguese people with initiative and capital would be necessary in those territories. ${ }^{11}$

Norton de Matos, high-commissioner of the Republic in Angola between 1922 and 1924, who was from Minho, a region of abundant emigration to Brazil, argued that, in the Portuguese colonisation of the Angolan plateaus suitable for white settlement, the rural establishment of families of agricultural workers in villages should be prioritised.These families, of the same geographical origin, would reproduce in Angola the households that already existed on the metropole, resulting from kinship and neighbourhood relations, and would work the land without use of African labour. Although the core of Norton de Matos's white settlement programme was rural, he also advocated an emigration of elites capable of raising the cultural level of the entire white population and contributing to the civilisation of the natives. ${ }^{12}$

After the establishment of the military dictatorship in 1926, it fell upon Vicente Ferreira, high-commissioner of the Republic in Angola between 1928 and 1929, to advocate an ambitious plan of settling the Angolan plateaus, which had several aspects: collective colonisation through the direct action of the State, singular colonisation for settlers with capital who would explore medium-sized farms, agricultural orphanages and agricultural penal colonies. However, he gave prominence to the collective colonisation with families of rural workers with few financial resources, coming from all the provinces of the metropole (continent and islands), in order to recreate the ethnic composition of the Portuguese population in Angola. In addition, they would maintain the 'immortal qualities of the race', which they would transmit 'magnified throughout the centuries' ${ }^{13}$ Nonetheless, and as a deterrent to the perceived unfitness for work and to moral misconduct, the legislative decree provided for the expulsion and repatriation of settlers. ${ }^{14}$

In the early years of the Estado Novo, the regime displayed no enthusiasm for the transfer of small-scale agriculture of the metropole to the colonies. The discourse that denigrated the Portuguese established in Africa at the expense of the State continued.Armindo Monteiro, Minister of the Colonies (1931-1935), criticised the settlers of the official rural missions for being dependent on state subsidy, for having accommodated to the condition of officials and for demeaning themselves in the eyes of the natives ${ }^{15}$ Only colonisation by capitalist private initiative won his praise. The settlers he presented as models were those who, with their own resources and without State support, embarked on the overseas adventure, bet on the creation of wealth and showed themselves capable of integrating African workers, contributing to the latter's elevation through work and education. ${ }^{16}$ 
The official view was that only individuals with technical knowledge, cadres and leaders of industry, commerce and above all agriculture, should migrate to the colonies. ${ }^{17}$ 'People who arrive without knowledge and capital are not lacking in Africa: we have millions of them. We are not in a position of spending money to transport them - and later, by force of circumstances, to repatriate them' ${ }^{18}$ This position was endorsed by the successive ministers of the colonies until the end of the 1940s.

The travel instructions for settlers, published by the Sociedade de Geografia de Lisboa (Lisbon Geographic Society) in 1945, explained the characteristics that those who set out to settle in Africa should possess: good psychological and physical conditions to adapt easily to the new environment without regretting or becoming sick. Moreover, the prospective settler should be entrepreneurial and determined to love the new land; he should be healthy, strong and relatively young. He should have some education and, at least, be able to read and write and have a trade, since, otherwise he would not have advantages over the Africans with whom he could not (and should not) compete in manual tasks. To prevent the settler from demeaning and lowering himself in the eyes of the native, he should only travel when he had a sure guarantee of work. ${ }^{19}$ While the liberal professionals would always have a sure occupation in the colonies, unskilled workers would hardly find a place there. Hence the latter were not considered suitable for Portuguese colonisation in Angola and Mozambique.

The booklet Brief Concepts for an Ideal Program of Portuguese Colonisation, published on the same occasion, conveyed the ideal type of settler: a patriotic individual, provident, exemplary, and moderate, a representative of the civilising race, who embodied 'the noblest Portuguese virtues', an example to the natives. ${ }^{20}$ And once again, besides the moral qualities, the settlers were supposed to have education and professional qualifications. Only then could a racially and socially cohesive settler community be built, protected from the threats and degrading influences of the surrounding environment and of the natives, aware of its superiority and mission, capable of welcoming newly arrived settlers, of imposing patterns of collective behaviour and ensuring their compliance. $^{21}$

It is important to note that the position favouring a small and qualified overseas migration was not ideologically hegemonic in Portugal, as can be attested by dozens of articles published in the Boletim Geral das Colónias and the presentations in the colonial congresses advocating the lifting of legal obstacles to colonial settlement and state investment in the intensive white colonisation. ${ }^{22}$

\section{Enclaves of rural Portugal in Africa}

Growing anti-colonial sentiment following the Second World War and the international dynamics towards decolonisation, on one hand, and revolts and unrest at local level on the other, imposed new development ideas and practices to reform and legitimise the European colonial empires in Africa. For 
that purpose, knowledge, planning and public funding were mobilised by the colonial governments in unprecedented ways. ${ }^{23}$ In the early 1950 s, Portugal replaced the terms "empire" and "colonies" with "Portuguese overseas" and "overseas provinces" in its Constitutional Law in order to sustain the idea of a multi-continental and multiracial country and to justify Portuguese permanence in Africa. The economic boom, due, in particular, to the rising prices of export commodities such as coffee and cotton, had a positive impact in the colonial economies, especially in Angola and Mozambique. From 1953 onwards, the Estado Novo launched a set of Planos de Fomento para o Ultramar (Development Plans for the Overseas Provinces), intended for six-year periods, to foster the economic and social development of the overseas territories and its inhabitants. ${ }^{24}$ In the initial plans the most significant expenditure was allocated to infrastructure, exploitation and use of natural resources, and settlement. Between 1940 and 1960 the European population of Angola rose from 44,000 to 170,000 , while in Mozambique it rose from 27,000 to 97,000. On the eve of independence in 1974 the European population was estimated at 324,000 and 190,000 respectively. The rapid increase in the Portuguese migration to Angola and Mozambique is linked to the economic growth of these territories - a definitive pull factor for migration not directed by the state - and the new official discourse and policy concerning demographic colonisation.

The overseas minister Sarmento Rodrigues (1950-1955) illustrated the new policy, stating that the government was willing to support all kind of measures that directly or indirectly could export the metropole's perceived demographic surplus to Angola and Mozambique:

I accept all systems, all contributions; I only see the settlement at the end of all acts. I come to subordinate everything to it, like a master idea. [It's] [p] ure deception. It is only a way - a long way - to reach the greatness of the united Nation.... It is possible that not everyone realizes this historical, genetic moment that we are going through..$^{25}$

Directed agricultural settlement was the only possible way. However, for reasons not yet fully understood, but which are partly related to the ideological foundation of Salazarism and to the agency of actors with real political influence, such as the governor-general of Angola, Agapito da Silva Carvalho, and the engineer António Trigo de Morais, the greatest public investment was directed to the creation of three major enterprises of planned agricultural colonisation: two in Angola (Cela and Cunene) and one in Mozambique (Limpopo). Its purpose was the 'tropical acclimatisation of the rural parish of the Metropole'. ${ }^{26}$

The colonato of Cela, located in the mild Amboim plateau in central Angola, was the first official colonato created in Angola during the Estado Novo. In terms of its size, the amount of public funds invested, and the number of families installed, it was also the most representative of the "model" colonatos. This was reflected in the manner it featured in the public imaginary, with Cela seen as 'a 
kind of living room of Angola, where the myth of Portuguese colonisation was exhibited to the admiration of strangers'. ${ }^{27}$

Silva Carvalho visited the Amboim plateau and was positive about its prospects, particularly after viewing the coffee farm of the Portuguese settler Gonçalves Magalhães in Gambagando (Cela), and hearing the farmer's enthusiasm for the land and the climate. ${ }^{28}$ As a result, Silva Carvalho issued a directive on 25 February 1949 for the identification and evaluation of areas potentially suitable for settlement and cultivation. With this aim, the Brigada de Estudos e Reconhecimentos Agronómicos da Repartição dos Serviços de Agricultura de Angola, headed by the agronomist Ilídio Barbosa, inspected the areas of the administrative posts of Cela, Ebo and Condé, and identified Cela as fulfilling the necessary criteria. Based on his impressions, Barbosa therefore endorsed Cela in his preliminary report, including the recommendation that a detailed survey of the area would need to be undertaken. This, however, was never requested by the colonial government. ${ }^{29}$ In 1958, the agricultural engineer Lains e Silva exposed the fact that Cela had been selected solely on account of Barbosa's impressions, not scientific analysis:

The idea that encouraged the Brigade to the venture of colonising the Cussoi valley was that of the apparent fertility of the lowland, an appearance derived from the existence of a vast plain of black humic soils, to which irrigation should ensure high productivity. [. . .] Thus was born the proposal of European colonisation of the Cussoi valley, based on the impressionist recognition, or rather, not to say, somewhat romantic recognition, which hastily led to the conclusion that the lowlands of the Cussoi valley were very fertile. ${ }^{30}$

Construction of the colonato commenced in May 1951 and the first settlers from Portugal's Trás-os-Montes, Ribatejo and Alentejo regions arrived two years later. These pioneers had been selected in the metropole by the engineer Francisco António Teixeira Boaventura of the Angolan Agricultural Services, whom the governor-general of Angola had appointed expressly for this purpose. In identifying potential settlers, the preference was for indigent rural workers with large families drawn from Portugal's most impoverished regions struggling with an excess of labour. Since the utilisation of African labour was prohibited on the colonato, selecting candidates with large families guaranteed a readily available labour supply for the cultivation of land. At the same time, recruiting families from already impoverished areas would discourage their return to their homeland. ${ }^{31}$

The first settlers who arrived in Cela were installed in the village ofVimieiro. There, they encountered serious problems: while houses were provided, these had no furniture and no piped water. In terms of the settlement and its activities, the authorities had promised to provide technical assistance and commercial infrastructure to support the farmers - yet none of this was in place. This was compounded by the proscription of the recruitment of native labour. In 
these adverse circumstances, several families decided to quit the settlement after just a few months - a development the authorities were careful to keep from becoming public. ${ }^{32}$

The regulation of the colonato of Cela ${ }^{33}$ anticipated that each settler would be assigned a plot of approximately $18 \mathrm{ha}$, an area considered to be appropriate for exploitation by a medium-sized family without use of African labour. ${ }^{34}$ Settlers were given cash advances for occupying the farm and investing in construction, implements and cattle. This credit was to be repaid over 25 years, from the fourth year after arrival. Along the margin of the lowland of the Cussoi river, fifteen villages, named after counterparts in Portugal, would be established with 25 to 30 agricultural smallholdings (casais agrícolas) each. ${ }^{35}$ According to the Missão de Inquéritos Agrícolas de Angola (Angolan Mission for Agricultural Surveys), the earmarked lowlands 'did not have an effective agricultural occupation' yet the Mission also acknowledged that this 'does not mean that, in the traditional African uses and rights, they [the lowlands] were considered without an owner'. In practice, the local African population was dispossessed and removed from the area to make way for the new settlers. ${ }^{36}$ The British Africanist historian David Birmingham published a short fictional story in 1999 about the removal of Ovimbundu farmers from the valley and the alienation of their land by the Administration of the Cela colonato. Birmingham's tale followed the archetypal Angolan peasant Kinyama, whose life personified the social and economic transformations in this community resulting from the policy of planned white colonisation. ${ }^{37}$ The agricultural engineer Jorge Bravo Vieira da Silva, at the time researcher of the Mission for Overseas Research Studies, recalls the violence of the removal during the enlargement of the colonato in 1961 as bulldozers razed native villages. The fact, which he witnessed and denounced to the overseas minister, proves that the space was not only occupied from the agricultural point of view but was also inhabited. ${ }^{38}$

Moreover, the colonato did not live up to expectations. While climate was congenial for human habitation, it was unsuited for the cultivation of either tropical or temperate climate crops. As a result, the settlers produced only poor quality products and had to sell them at very low prices, far below what they would have been accustomed to reach in Portugal. This was compounded by the great distance, or even complete absence, of suitable markets. ${ }^{39}$

Despite these poor results, the state persisted with the expansion of the colonatos, maintaining that the lands were fertile and ascribing any failures to the incompetence of the settlers and the lack of water. ${ }^{40}$ Considering the economic difficulties of the families installed in these villages, the initial theoretical framework was adjusted and adapted to the circumstances; the planned agricultural productions and the agricultural character of some villages were diversified. In 1958, it was decided to settle new families in larger farms, oriented to more profitable crops (the medium-sized farms). Generally, the results were similarly poor. $^{41}$

Initially, the sale of products was made through warehouses and the canteen of the Brigada Europeia of Cela (a technical agency of the Angola government). 
The settlers disliked this system because the debits were discounted; and in 1955-1956, they started selling their agricultural production to the merchants who had in the meantime settled in the village of Santa Comba, and with the truck drivers who transported goods to Luanda. ${ }^{42}$

Of the first 28 families that went to the colonato, only ten remained there in 1959. In 1962-1963, 224 agricultural smallholdings were occupied (containing a total of 1,166 individuals), but in 1967, there were only 192. In April 1970, the vacant houses began to be sold by public auction, and in the following year it was decided to sell 126 houses. ${ }^{43}$ By $1964,1.5$ million contos had been spent in the colonato of Cela. According to an estimate, the cost of the installation of each family in Cela was about 2,860 contos. $^{44}$

The preparation works of the agricultural explorations and the construction of the villages and the town of Santa Comba attracted hundreds of workers and technicians. Despite some mishaps and indecisions, the State invested large sums in the colonato of Cela and in the infrastructures of Santa Comba, which in the medium term became an administrative and commercial centre ${ }^{45}$ with a hospital with 120 beds, schools for about 500 children, a church (a replica of the one in Santa Comba Dão, place of birth of Salazar), public buildings, residences for workers, a market, a hotel, etc. Thanks to the heavy expenditure and to the creation of an urban centre within it, the colonato of Cela evolved and became viable. Orlando Ribeiro's notes of his two visits to the colonato, in the beginning and end of the 1960s, account for this evolution. ${ }^{46}$ In 1960, the geographer commented that the experience of Cela was desolate: it had been established in soils that had not been previously studied, it was directed to producing commodities whose sale had not been assured, it resorted to the routine techniques of the ox cart and the plough, the available agricultural machinery was not used (it was not adapted to the land, parts were missing as well as people who knew how to operate it), and the settlers led a very difficult life. In 1969 he was surprised to find 'the colonato in better conditions and the town of Santa Comba, transformed into an important services centre, lively and with a varied and prosperous commerce'. Industrial units had already been created in the area for the processing of the agricultural products. Since, in contrast to the initial project, the white settlers were not able to generate sufficient income utilising only family labour, African labour and agricultural machinery were widely used. Irrigation was in development. However, this positive picture continued to be tarnished by the lack of technical assistance, by economically irrational decisions ${ }^{47}$ and by an arbitrary and authoritarian direction without respect for settlers. In his notebook, Orlando Ribeiro wrote: 'Administrator of Santa Comba: appointed for being tough and therefore to be able to solve the impertinences of the settlers "by slap"! Admirable concept of the head of services and proof of racial indiscrimination.... A technician of the colonato uses the sjambok, which we saw in the seat of the truck'. ${ }^{48}$

The colonatos of Cunene (in the valley of that river, district of Huila, South of Angola) and of Limpopo (in the valley of the same river, district of Gaza, South of Mozambique) were established in 1954. They were based on irrigation and in 
conjunction with hydroelectric dams and arose from an idea of the civil engineer Trigo de Morais, who had been the director of the Junta Autónoma de Obras Públicas e Hidráulica Agrícola (Autonomous Board of Public Works and Agricultural Hydraulics, 1934-1949), state undersecretary of the overseas (1951-1953) and held the position of general inspector and president of the Fomento Ultramarino. According to the engineer and geographer Mariano Feio, ${ }^{49}$

irrigation has very little interest in the tropics (except in arid and semi-arid climates), unlike the Mediterranean climate, because in the latter the hot season is sterilised by the dryness, while in the tropics the rainy season is hot, so the crops suitable to these conditions can be grown with free irrigation from the clouds. Thus, in the plateaus, one can say that only orchards (to pass dry season, which is long) and gardens need watering.

He observed that these differences were not understandable, dominating 'the mystique of the transplantation of Portuguese agriculture - familial, small property, intensive cultivation, work by arm and cattle, further imposed by the strong personality of Trigo de Morais, who had already been the apostle of irrigation in the metropole'. ${ }^{50}$

Unlike the colonato of Cela, these new enterprises would include white and black settlers. In the words of Overseas Minister Raul Ventura, the option of including natives 'represents only the disguise of a reality: we could not do a work of exclusive European settlement because the place chosen [. . .] was densely populated with natives and, in our political conceptions (and our fears), native should not be expelled' ${ }^{51}$

Thus, although the proposed law took the colonato of Limpopo as a factor of white settlement (3,000 families), the Câmara Corporativa (Corporative Chamber) and the Assembleia Nacional (National Assembly) immediately drew attention to the problem of the Africans living in the area. The Overseas Ministry together with the General-Government of Mozambique opted for the mixed colonato. The undersecretary of state, the engineer Trigo de Morais, in an order addressed to the Brigada Técnica de Fomento e Povoamento do Limpopo (Technical Brigade of Development and Settlement of Limpopo), underlines that 'It is a work in which the joint life of whites and blacks has to be fraternally connected by the yearning of the spiritual and material aggrandisement of the Nation'. ${ }^{2}$ Overseas Minister Sarmento Rodrigues approved this plan.

In the colonato of Cunene, Trigo de Morais admitted at the start that the inclusion of the African population would be on a small scale. In his opinion, the native of that area was 'in a depressing degree of backwardness', which did not allow the same involvement as in Limpopo. ${ }^{53}$ The selection of white settlers to be installed focused on rural families, without any assets or material links to the metropole. Francisco de Almeida eVasconcelos, who was responsible for the recruitment of settlers to Limpopo and Cunene, informed that 435 individuals were recruited from 'amongst families of rural workers who did not have any material interests that could still tie them to the metropole'. ${ }^{54}$ 
Before presenting the Cunene colonisation project to the president of the Conselho, Trigo de Morais commissioned a study from Professor Botelho da Costa. The result of the study of an area of about 50,000 ha was discouraging: 'There are [only] some spots [of] soils suitable for irrigation, each of which has no more than 2,000 or 3,000 ha', in a total of 8,000 ha. The soils of the Cunene basin were, therefore, far from ideal for irrigation. However, Trigo de Morais managed to convince Salazar and his project was approved. ${ }^{55}$

Located in soils unsuitable for irrigation, in a region of healthy climate, at an altitude of about $1,230 \mathrm{~m}$ in southern Angola, the colonato was at a great distance from the nearest urban centres: $160 \mathrm{~km}$ to Sá da Bandeira, $230 \mathrm{~km}$ to Moçâmedes and $280 \mathrm{~km}$ to Nova Lisboa. ${ }^{56}$ Established in conjunction with the Cunene hydroelectric dam, it was formed by the town of Folgares and the villages of Freixial, Algés-a-Nova, Castanheira de Pêra and Matala.The first eleven settler families to arrive (a total of 71 people) were from the municipality of Mirandela (Trás-os-Montes). Each settler was given: a house, an irrigated property (5-10 ha), a plot of 0.5 ha in the communal land (it failed shortly after), and a plot of 30 ha of dry land for cattle (this parcel was not distributed). Settlers had to give one-sixth of their income to pay the advances, namely the cost of the irritation works and the buildings. The distance between the houses and the fields was too long (half an hour on foot). ${ }^{57}$

Both yields (of tobacco, tomato, potato, wheat and rice) and prices were low. The problem of commercialisation turned out to be very acute, because the centres of consumption (modest and locally supplied) were at enormous distances and roads were terrible. The income per settler was lower than in the metropole, although the cost of living in the colony was higher. ${ }^{58}$ The colonato services took into account the need to transform the products, having built industrial structures from the start to prepare tobacco; to grind, dehydrate and flour lucerne; tomato paste and packaging. ${ }^{59}$

By the end of 1958, 157 European settler families were established in the colonato; in 1963, the number of families had increased to 324; in 1968, it had fallen slightly to 319 . The cost of installing an agricultural couple, including irrigation and the distributed assets, was valued at 393.2 contos. ${ }^{60}$ To keep the promise of forming a mixed colonato, 39 African settlers were installed on an experimental basis, with irrigated plots of land of 2.5 ha and no buildings. ${ }^{61}$

The Limpopo irrigation project dated back to 1920, when the valley 'was still bush and poorly explored'. ${ }^{62}$ British engineer John Aylmer Balfour had been invited by the governor Moreira da Fonseca to study the possibilities of irrigation and drainage in the Limpopo valley. Despite the favourable conclusions, the policy of agricultural development through irrigation did not proceed, because it conflicted with the interests of the South African mining industry. ${ }^{63}$ Likewise, the project of Trigo de Morais, drawn in 1925 and resumed in 1936, was not put into practice. It was thought that the colonial agriculture in the South of Mozambique, even the one irrigated, could not prevent Mozambican labour from emigrating to the Rand mines. ${ }^{64}$ 
The official colonisation of Limpopo was initiated in 1954, with eight families from Alentejo and two from Madeira. The property distributed to the settlers and the legal regime imposed was very similar to that of the colonato of Cunene. ${ }^{65}$ In 1958, when the I Plano de Fomento came to an end, 262 families of European settlers and assimilados were installed in 13 villages, and 650 families of Africans (who were, however, settled on a tract of communal land), in a total of more than 5,000 individuals. ${ }^{66}$ From 1959, some assimilated African settlers were integrated into the colonato as settlers of full right, in other words, with the same conditions as the white settlers. In 1968, the colonato already had 10,000 inhabitants, making the municipality of Baixo Limpopo one of most populous in Mozambique. The number of full right African settlers grew considerably: about one-third of the 1,593 settlers installed in the colonato were of African origin. But by 1974 that number had diminished to 1,380 settlers, of whom 968 were from the metropole and 412 were African. In a portion of communal lands, 2,584 were African. ${ }^{67}$

Rice, land for grazing and dark tobacco predominated in the irrigated perimeter of the villages upstream and in the centre of the valley; downstream was better suited to the production of cotton, light tobacco, tomato, citrus fruits and textile fibres. From the beginning, the need for preparation and industrialisation of agro-livestock products of the colonato was understood, and consequently some industrial structures were built. ${ }^{68}$ However, the settlers' standard of living was generally low, the technical support and medical assistance were insufficient, and the discipline imposed in the colonato was too rigid. Despite contracts prohibiting the use of paid labour, Portuguese settlers always did so. ${ }^{69}$

Over the years, the need to increase the area of land distributed to the settlers was recognised. From the initial 4 ha it increased to 10 ha in 1960; and by 1965 it was possible to acquire up to 20 ha. However, the size of the white settlers' lands was always higher than that of Africans, averaging 8.5 ha against 5.9 ha. The introduction of machinery was also done unequally: of the 197 tractors purchased by settlers between 1961 and 1973, only 12 percent belonged to Africans, although the latter were one-third of the total number of settlers; the same unequal distribution existed in the possession of vehicles and agricultural implements. ${ }^{70}$

Regarding the prospect of a second phase of the settlement of the Cunene valley and in the Limpopo valley, under the II Plano de Fomento, the Overseas Minister Raul Ventura cautiously evaluated the results obtained so far. He stressed that 'above all it is necessary to avoid a racial conflict in Mozambique', thus reacting to the problems encountered with the natives of the Limpopo area, who did not want to abandon their lands, even if they were promised irrigated plots, which they considered too small. He referred to the high cost of the enterprises - the calculation made by the Inspecção-Geral de Fomento relative to the installation cost of each individual European settler pointed to 230 contos but assumed that the colonisation would continue up to the 3,000 families. If the settlement ended in 1958, the expense with each settler would amount to 1,322 contos. He suggested that new settlers be installed with the funds from 
the first phase, and only afterwards reflect on the convenience of extending the irrigated area. ${ }^{71}$

Despite Trigo de Morais's instructions, ${ }^{72}$ the implementation of the irrigation plan of Limpopo implied the expulsion of Africans from their lands (machambas), which created discontent. The coexistence of white and African settlers was very problematic, with daily acts of threats, violence and insults. A report by the local police blamed the white settlers sent by the Overseas Ministry for the social tension: they stole livestock from the Africans, took their cattle to graze in the Africans' lands, spent their time in the tavern drinking, and did not take care of hygiene. ${ }^{73}$ However, many Africans themselves did not blame the settlers for the problems brought by the colonato. They saw that the settlers were poor like them and worked the land with their own hands. ${ }^{74}$

The memory that persisted amongst the elders of Guija shortly after independence about the first Portuguese settlers installed in Limpopo was related to the extreme poverty of the latter. Abner Ngwenga recalled during an interview:

They did not even have shoes when they got here for the first time. The whites here gave them blankets, clothes, and shoes when they disembarked at the port of Lourenco Marques. This was done at night so that the blacks did not see that those settlers were badly dressed and barefoot. In the morning they were put on a train to Guijá. ${ }^{75}$

The Africans' expectation of the appearance of whites did not correspond to what they observed in settlers newly arrived in the colonato. The posture and behaviour of the settlers were also a source of strangeness, and generated in some Africans a feeling of superiority:

They did not employ anyone to cultivate for them, for they did it by themselves - husband and wife, with their own hands. [...] So it happened that when a Negro asked his own wife: 'My wife, can you make me this or that' the answer was 'I am not a settler ...' (to make such low services). The blacks looked at the settlers with contempt.

[...] we found it very strange to see the settlers walking from house to house selling cabbages which they carried on their heads in conical baskets, trumpeting 'cabbage, cabbage!' In this area, we did not know that whites could go around selling vegetables [...].

When they arrived here, they saw, for example, that the members of the Chambele family cycled to the machamba, while they, the settlers, walked. When they came to Guija they did not expect to find people with a good standard of living, like the Chambele. ${ }^{76}$

The fact that they were poor, and used poor clothing and footwear, were not very edifying examples for local Africans, and led to the "settler" becoming synonymous with 'poor man from Portugal'. ${ }^{77}$ An administrative inspector alerted in confidential information: 'All our steps are closely followed by the natives 
and we have to impose ourselves before them, stand by our actions: barefoot, going to the rivers and living, like them, almost in promiscuity with livestock, we do not impose ourselves'. ${ }^{78}$

The lack of schooling of the Limpopo settlers was also a cause for much criticism from the higher strata of the Portuguese settler society in Mozambique. In the initial plan, one of the admission criteria was that the head of the household knew how to read and write, but in practice illiterate settlers were chosen. Since in the Limpopo area there were assimilados Africans, it was often found that it was the latter that read the newspaper and wrote the letters to the settlers. ${ }^{79}$ The situation is reported by Commander Gabriel Teixeira in the Conselho Ultramarino session on settlement:

To send there settlers who are only good people but are inferior to the black does not work. In the colonato of Limpopo [... . many of the settlers [...] were simple hoe workers, and despite all the selection made, there were many illiterates there who asked the black to write family letters. [...] The black, in his simplicity, solved the problem in the following way: there is the white from Lisbon and the white from the bush of Lisbon. ${ }^{80}$

Professor Silva Rego, however, did not see the illiteracy of settlers as an inconvenience because 'they were as carriers of lusitanidade [Portugueseness] as the others'; and considered that 'one of the great virtues of our colonisation was to never be afraid of "poor whites"" ${ }^{81}$ He mentioned that he had seen countrymen from the village of Joane (Minho), who lived in the muceques (slums) of Luanda, living side by side with natives, asking the latter to read them the letters. He argued such a fact 'should not embarrass us' because 'This fusion between destitute whites and Africans is also a condition and a circumstance which will help mutual understanding between one another' ${ }^{82}$

A study of the social situation in the colonatos of Matala and Limpopo criticised the housing for being poorly adapted to the climate and unhygienic. ${ }^{83}$ The stables were built next to the houses, which could be acceptable in the metropole, but in Limpopo, where the climate is very hot and the insects are abundant, this was a problem. Moreover, the houses did not respect the norms of location and size followed in the province; and the cemetery was made in impermeable terrain. The study furthermore criticised the distance between houses and plots of land, the settlers' advanced age and low schooling levels and the disparity between boys and girls at marriageable age. It is said that the settlers' daughters did not want, in general, to marry the settlers' sons, because they wanted to climb socially. In this regard, the picture of Limpopo was considered alarming:

[here] is part of the reason why the boys are going to look for the native girls in the neighbourhood. And because, unfortunately, the European does not usually marry the native girl, this results in the revolt of the girl's parents and even of the tribe, as one of the Régulos da Vizinhança said: 'parents can forgive, but the difference in colour that the child presents constantly 
reminds the whole tribe of the misconduct and abandonment of which the girl was victim by the child's father', ${ }^{84}$

In the colonato of Cunene, the daughters of the settlers were forbidden to marry officials, so they would marry the sons of settlers, but 'in face of the bad results that followed, both moral and social, the prohibition was lifted' ${ }^{85}$

Few sources thoroughly provide the voice of the settlers. There is very sparse information in academic or scientific works. ${ }^{86}$ These show that settlers were generally unhappy with their economic situation, were poorly motivated, and it does not seem that they had internalised the civilising mission which propaganda attributed to them. Whereas the journalist of the newspaper A Provincia de Angola, visited the colonato of Cela and saw 'that those people, rude and healthy as the old land of Trás-os-Montes had the heart overflowing with joy and recognition', ${ }^{87}$ Orlando Ribeiro, in 1969, wrote in his field notebook: 'The "shown" settlers did not show themselves enthusiastic, how will the others be!'88

The negative views of settlers, their own discontent, and the problems that arose in model colonatos were always hidden from public opinion. Censorship services cut the articles that denounced the settlers' difficulties. ${ }^{89}$ Information from the Gabinete de Negócios Politicos of the Overseas Ministry addressed the discontent of the Cunene settlers, given the low price of the products and the delay in their payment; and the abandonment of the colonato by the settlers' children, with the aim of improving their lives, generally heading towards the Cassinga mining region. ${ }^{90}$ Facing the despondency and desertion of many settlers, it was again argued, in a private or confidential way, that the selection had not been rigorous, that they had chosen illiterates, individuals without agricultural experience, who felt superior in Africa and did not want to work alongside the natives. Negative consequences about race relations and the removal of Africans who lived in the occupied areas were also underestimated. But politicians and propaganda insisted on praising the colonato of Cela - 'within years with 100 villages, it will be an entirely white district in black Africa, a miniature Portugal inside its largest province from which it will radiate colonizing energy" ${ }^{91}$ - and the work of the engineer Trigo de Morais - 'on his own initiative [...] great overseas settlement works were executed, which are true workshops of ethnic-cultural convergence, where the process of lusotropicalism accelerates'.$^{92}$ In this last case, due to the political imperatives dictated by the involvement in the colonial wars, the emphasis was placed on the contribution to the creation of multiracial societies.

\section{Conclusion: contradictions, misapprehensions and paradoxes}

The state-connected media and propaganda apparatus of the Estado Novo represented the Portuguese settlers of the colonatos in a manner which differed significantly from representations in contemporary scientific studies, and from the dispassionate and crude perceptions held by the settlers themselves, as well as by their other white and African neighbours. The colonatos in "Portuguese 
Africa" were based on multiple misconceptions and paradoxes. They were created in a period of accelerated economic development, anchored in technical and scientific knowledge, with which it was sought to relegitimise the empire against the advance of the anticolonial movement. ${ }^{93}$ Tiago Saraiva points out that 'to fulfil the vision of a rural Portugal', those enterprises were inserted 'in large state plans where technology plays a fundamental role'. ${ }^{94}$ In turn, science (agronomic, economic and social), though mobilised by political power - a priori or a posteriori - to give the colonatos a scientific basis, was often overlooked for opposing idealised or already ongoing measures.

The rigid and subservient discipline that was imposed upon the settlers did not hold them individually and socially responsible. Land ownership, the engine of attachment to land and permanent settlement, remained elusive. Moreover, the delivery of the plots of land was arbitrary, as these could be given and withdrawn by the state. ${ }^{95}$ As a programme of deproletarianisation, ${ }^{96}$ that is, of transforming the rural wage earners of the metropole into well-rooted landowners in Africa, the colonatos failed. Unable to raise the living conditions of the populations involved, they experienced high drop-out rates. The settlers' children, when they became adults, typically sought jobs in the cities. The goal of securing national sovereignty and security in interior areas of Angola and Mozambique by populating them with white settlers in the colonatos was compromised.

As I have argued elsewhere:

settlers who were mobilised for the official colonatos occupied a sui generis place within the group of the so-called colonisers. Despite all the rhetoric, propaganda and idealisation of the rural settler, he was always a minority in the whole of the overseas migration and did not correspond to the average social profile of the Portuguese who fixated in Africa: with higher educational and professional qualifications, mostly urban and working in commerce, services and public administration. ${ }^{97}$

The settlers who established themselves in the cities, that is, the bulk of the white Portuguese in Angola and Mozambique, did not identify with the rural settlers. In fact, they perceived themselves as cosmopolitan, enterprising, and successful. The children of settlers, the so-called 'second-rate Portuguese', ${ }^{98}$ heavily concentrated in urban centres, open to cultural interactions and international mass consumption, ${ }^{99}$ were still less likely to identify with villagers, hoe workers, regarded as caricatures of an archaic Portugal. That difference was perceived and emphasised by some of the colonised, who did not see the distinctive marks of racial and civilizational superiority on the rural settlers.

\section{Notes}

1 This chapter was translated from Portuguese by Ana Rita Amaral, with the assistance of Duncan Money.

2 Cooper and Stoler, 'Introduction'. 
3 Stoler and Cooper, 'Between a Metropole and a Colony', 6-7.

4 The average Portuguese settler in Angola and Mozambique in the mid-twentieth century moved spontaneously and without state assistance, lived in the major cities, had schooling levels above the national average, and worked in the trade and services sector. Cf. Castelo, 'Colonial Migration'.

5 The archival sources used for this chapter are housed in Arquivo Histórico de Moçambique, Maputo (AHM); Arquivo Histórico Ultramarino, Lisbon (AHU); Arquivo Histórico Diplomático, Lisbon (AHD) and Arquivo Nacional Torre do Tombo, Lisbon (ANTT). The printed primary sources and the personal archive of Orlando Ribeiro were consulted in the Biblioteca Nacional de Portugal (BNP).

6 For details on the regulations controlling the migration of Portuguese nationals to Angola and Mozambique, see Castelo, Passagens para a África, 86-87, 128, 134, 136.

7 Ribeiro, Regras e preceitos de higiene colonial ou conselhos práticos aos colonos e emigrantes que se destinam às nossas colónias do Ultramar, 2nd edition; Ribeiro, Guia higiénico do colono nas terras mais insalubres da África central; Nascimento, Questões medico-coloniaes relativas à colonização Europea no Planalto de Mossamedes (Huíla:Typ. Missão Catholica, 1891); Nascimento, A colonização do Planalto de Benguella.

8 Ferreira Martins, Ensino Agrícola Colonial: Comunicação Apresentada ao Primeiro Congresso de Agricultura Colonial, Porto, 1934 (Porto:Tip. Sociedade Papeleira, 1934), 5.

9 Camacho, Questões Nacionais, 83.

10 Ibid., 183.

11 Costa, Estudos de Economia Nacional, 172-173.

12 Matos, A Província de Angola, 28-29.

13 Alto Comissariado da República, Estatuto Orgânico dos Serviços de Colonização: Aprovado por Diploma Legislativo, $n .{ }^{\circ} 704$ de 9 de Março de 1928 (Luanda: Imprensa Nacional, 1928), foreword.

14 Ibid.

15 Monteiro, 'Inimigos da colonização. Discurso proferido na inauguração da Exposição Colonial do Porto, em Janeiro de 1934', O Mundo Português, 5 (1934), 353-361.

16 Monteiro, Os portugueses na colonização contemporânea, 6; Monteiro, Para uma Política Imperial, 59.

17 Salazar, Discursos e Notas Políticas, 159, 163.

18 Monteiro, Directrizes duma Política Ultramarina, 27.

19 Santos, Como o Colono Se Deve Preparar.

20 Santos, Breves Conceitos para um Ideário de Colonização Portuguesa.

21 Ibid.

22 Castelo, Passagens para a África, 78-79.

23 See Hodge and Hödl, 'Introduction'.

24 First Development Plan: 1953-58; Second Development Plan: 1959-64; Intercalary Development Plan: 1965-67; Fourth Development Plan: 1968-73.

25 Rodrigues, Unidade da Nação Portuguesa, x-xi.

26 Ministério do Ultramar, Missão de Inquéritos Agrícolas de Angola, Recenseamento Agrícola de Angola (Luanda: MIAA, 1964), 14.

27 Ribeiro, A Colonização de Angola, 183. Orlando Ribeiro, a geographer and professor at the Faculdade de Letras in Lisbon, visited the colonato of Cela in two campaigns of the Missão de Estudos de Geografia Física e Humana do Ultramar Português.

28 Dala, 'O Colonato europeu da Cela é uma magnífica realidade que atrai as atenções do mundo', Jornal de Angola, June 1955, 2.

29 Lains e Silva, Aspectos Agronómicos e Económico-Sociais do Colonato da Cela (Lisbon: Missão de Estudos Agronómicos do Ultramar, 1961), 7-8.

30 Ibid., 8.

31 See AHU, Ministério do Ultramar, Gabinete do Ministro, Proc. 70, Sala 2, no. 280, Telegram from the Overseas Minister to the Angola Governor-General, 16 February 1953. 
AHU, Ministério do Ultramar, Gabinete do Ministro, Proc. 44 A, vol. I, Sala 2, no. 132, Portugal de Além-Mar - Emigração inopinada do colonato europeu de Cela Falando com os colonos que regressam (Frederico Filipe, correspondente de O Comércio do Porto, em Benguela)', Secção de Expediente e Cifra do Ministério do Ultramar, 3 November 1953.

32 See AHU, Ministério do Ultramar, Gabinete do Ministro, Proc. 44 A, vol. I, Sala 2, no. 132, Portugal de Além-Mar - Emigração inopinada do colonato europeu de Cela Falando com os colonos que regressam (Frederico Filipe, correspondente de O Comércio do Porto, em Benguela)', Secção de Expediente e Cifra do Ministério do Ultramar, 3 November 1953.

33 'Diploma Legislativo n. ${ }^{\circ}$ 2550, de 5 de maio de 1954', Boletim Oficial de Angola, 18, 5 May 1954.

34 The intention was to prove that European families could be self-sufficient in Africa. This prohibition was contested by the settlers and was lifted in 1963 .

35 The smallholding defined as the house serving as dwelling for the settler family with attached agricultural land, was indivisible and allotted to a head of family from the metropole.

36 Ministério do Ultramar, Missão de Inquéritos Agrícolas de Angola, Recenseamento, 13. This body was created by the Portuguese government to supply data for the 1960 World Census of Agriculture launched by the Food and Agriculture Organisation of the United Nations.

37 The story is titled 'Colonialism in Angola: the Kinyama's Experience' in Birmingham, Portugal and Africa, 122-132.

38 'Depoimento de Jorge Bravo Vieira (2016)', audio recorded by Cláudia Castelo, Paris, 27.09.2017. Interview transcript, 19.

39 Lains e Silva, Aspectos Agronómicos e Económico-Sociais, 13-14; Feio, As Causas do Fracasso, $38-50$.

40 Lains e Silva, Aspectos Agronómicos e Económico-Sociais, 15.

41 See ANTT, Arquivo Oliveira Salazar, AOS/CO/UL-40, pt.3, Memorando sobre a situação das fazendas médias da Cela em fins de Julho de 1963. AHU, Ministério do Ultramar, Direcção-Geral de Economia, Grupo de Trabalho de Povoamento, Pareceres sobre diversos estudos, vol. 3, Information no. 2/DP72, de 13.6.1972, Junta Provincial de Povoamento de Angola, which states that, in October 1971, in face of the economic failure of Cela's medium-sized farms, the concessionaires requested the Overseas Minister suspend the taxes they were subjected to until an impartial investigation of the situation was made.

42 Feio, As Causas do Fracasso, 37.

43 Ibid., 44.

44 Bender, 'Planned Rural Settlements in Angola'; Bender, Angola sob o Domínio Português, 160.

45 On Santa Comba becoming a town in 1970, see 'Santa Comba, capital do povoamento, é elevada a cidade', 38-41.

46 Ribeiro, A Colonização de Angola, 184-185.

47 Orlando Ribeiro reports that the colonato's administration distributed dairy cattle bought in Denmark to farmers, while there were breeds better suited to local conditions in South Africa. Ribeiro, A Colonização de Angola, 185.

48 BNP, Arquivo de Cultura Portuguesa, Espólio de Orlando Ribeiro, Caderno de campo de Angola, fls. 5-6.

49 Mariano Feio studied civil engineering at the Instituto Superior Técnico, and studied Geology, Paleontology and Geomorphology in Germany. He collaborated with Orlando Ribeiro in the Missão de Geografia Física e Humana do Ultramar Português, conducting several fieldwork expeditions in Angola, namely carrying out a geomorphological study of the river Cunene. Daveau, 'A obra geográfica de Mariano Feio'. 
50 Feio, As Causas do Fracasso, 59.

51 ANTT, Arquivo Oliveira Salazar, AOS/CO/UL-63, pt. 2, Document signed by Raul Ventura about the preparation of the II Plano de Fomento, dated 22 June 1957, fl. 9.

52 Cited in Almeida, 'Colonato do Limpopo', 39.

53 AHU, Ministério do Ultramar, Gabinete do Ministro, Proc. Correspondência sobre o Plano de Fomento (1951-1959), Sala 2, no. 35, Letter dated 31 September 1954, to the Overseas Minister.

54 AHU, Inspecção Geral de Fomento Ultramarino, Proc. 3-A, Sala 3, no. 3200, Letter dated 31 December 1955 to the Engineer Inspector General of Development.

55 Ricardo, Rui Pinto Ricardo, 12.

56 Feio, As Causas do Fracasso, 59.

57 Ibid., 60.

58 Margarida Silva e Castro, Monografia do Colonato do Cunene (Matala) (Luanda: MIAA, 1971), 119 ff., apud Feio, As Causas do Fracasso, 62.

59 Feio, As Causas do Fracasso, 62.

60 Barata, 'O aproveitamento do Cunene', 62, apud Feio, As Causas do Fracasso, 60. Bender estimates that the establishment of each family costed about 715 contos (one 'conto' was one hundred escudos, the Portuguese currency at the time). Bender, Angola, 160.

61 Feio, As Causas do Fracasso, 60.

62 Covane, O Trabalho Migratório e a Agricultura, 223.

63 Ibid., 147.

64 Ibid., 150.

65 See Presidência do Conselho, Secretariado Técnico, Relatório da Execução do II Plano de Fomento Ultramar: 1959-1964 (Lisbon: Imprensa Nacional, 1970), 813-815.

66 Portugal, Presidência do Conselho, Secretariado Técnico, Relatório, 809, 812.

67 Hermele, Land Struggles and Social Differentiation, 44.

68 Portugal, Presidência do Conselho, Secretariado Técnico, Relatório, 810-811.

69 Hermele, Land Struggles and Social Differentiation, 42.

70 Ibid.

71 ANTT, Arquivo Oliveira Salazar, AOS/CO/UL-63, pt. 2, Document signed by Raul Ventura, 22 June 1957.

72 See the order of the Inspector-General Trigo de Morais, 25 May 1953, which begins: 'It would have been a great error to start the action of the Brigada in the Limpopo Valley with the expulsion of the Africans from their villages (sanzalas) and their lands (machambas) ..., AHM, Fundo do Governo-geral, L/10, cx. 489, Confidential letter from the Administrator of Bilene, dated Macia, 12 February 1957.

73 Apud Covane, O Trabalho, 227.

74 Hermele, Land Struggles and Social Differentiation, 38.

75 Manghezi, Trabalho Forçado e Cultura Obrigatória do Algodão, 81.

76 Ibid., 81-82.

77 Moreira, 'Aspectos económicos e sociais', 258.

78 Cited in Castelo, Passagens para a África, 151.

79 Covane, O Trabalho, 226.

80 AHU, Ministério do Ultramar, Conselho Ultramarino, Actas da Sessão Plenária de Outubro de 1965, fl. 13.

81 This statement contradicts the position taken by A.A. Mendes Correia in the discussion about the prior warning of Armando Cândido on the demographic excess related to emigration and colonisation at the Assembleia Nacional.The deputy, a physical anthropologist and director of the Escola Superior Colonial, considered it 'a crime to create in Africa legions of white people, human rags, degraded to a more miserable condition than that of the rudest and backward blacks.' Mendes Correia, Aumento da População, Colonização, Emigração, 15.

82 AHU, Conselho Ultramarino, 1965, fl. 21. 
83 ANTT, Arquivo Oliveira Salazar,AOS/CO/UL-38, pt. 3, M. Luísa Ressano Garcia, 'Elementos de estudo dos colonatos do Limpopo e do Cunene para um subsequente plano de Serviço Social' (Typewritten document, December 1959).

84 Ibid., 18-19.

85 Ibid., 52.

86 For example,Almeida, 'Colonato do Limpopo'; Castro, Monografia do Colonato do Cunene; Moreira, 'Aspectos económicos e sociais'.

87 Dala, 'O Colonato', 2.

88 BNP, Arquivo de Cultura Portuguesa, Espólio de Orlando Ribeiro, Caderno de campo de Angola, fl. 164.

89 See AHD, MU/GNP/158/pt. 17, Note no. 766, Matias da Silva, 18 March 1971, about the 'cuts' made in a report on the village of Senhora da Graça in the colonato of Limpopo, which denounced the lack of water and the discontent of the settlers.

90 See AHD, MU/GNP/163/pt. 12C, Information no. 2689, J. Catalão, 11 November 1968.

91 Rebelo, Angola na África, 121.

92 AHD, MU/GNP/161/pt. 7, Comment no. 178, 1 August 1967, José Alberto Pereira Monteiro, titled "Um servidor da Portugalidade".

93 Cooper and Packard, International Development and the Social Sciences, 7.

94 Saraiva, 'Paisagens Tecnológicas'.

95 'As we are entitled to give land, we can also take it away.' BNP, Arquivo da Cultura Portuguesa, Espólio de Orlando Ribeiro, Caderno de campo de Angola, fl. 10. Emphasis added.

96 A discussion about the logic of deproletarianization of rural wage earners carried out in the south of continental Portugal by the Junta de Colonização Interna, in Silva, 'A Propriedade e os Seus Sujeitos', 28.

97 Castelo, 'O 'branco do mato de Lisboa', 27-28. For a demographic and social characterization of the Portuguese who settled in Angola and Mozambique between the end of World War II and the eve of decolonization, see Castelo, Passagens para a África, 174-214.

98 This category is mainly symbolic and without translation or legal implication.

99 Cardão, 'Fado Tropical', 357. 


\title{
7 Labour and mobility on Rhodesia's railways
}

\author{
The 1954 firemen's strike
}

\author{
Nicola Ginsburgh
}

\section{Introduction}

Doris Lessing's The Grass is Singing vividly captures the reality of many socially aspirant Europeans who settled in Southern Rhodesia. Freshly arrived from England, Tony Marston is hired as a farm manager for Dick and Mary Turner, poor whites plagued by years of agricultural failure and social isolation. Tony's unbridled optimism for his own future is reflected in his belief that he will soon enough profitably run his own farm. The most successful farmer in the district, Charlie Slatter, a "proper cockney" who started life as a grocer's assistant in London, makes no attempt to hide his resentment towards Tony whose accent, education and relatively liberal racial views mark him as an outsider. Charlie's unease over Tony's presence intensifies when African farm labourers rush to inform him that Mary's dead body has been found on the Turners' property. ${ }^{1}$ While Tony, the nearest European to the scene, feels "insulted" that he had been overlooked by the African farm labourers, Charlie and the police sergeant present to investigate the death 'seemed to think it right and natural that he should be bypassed in this fashion, as if his newness to the country unfitted him for any kind of responsibility'. Tony, suspicious that Mary Turner had pursued a sexual relationship with her African domestic servant, is cowed into silence by the two men. Information of this nature was feared to cause irrevocable damage to white prestige and lower the status of all whites in African eyes and Tony retreats to the city; alienated, angered and painfully aware that in order to prevent his permanent ostracism from the settler community he must rapidly adopt certain racialised behaviours and attitudes. ${ }^{2}$

The interactions between Tony Marston and the established settlers in Lessing's novel speak to a central tension at the heart of settler colonialism in Southern Rhodesia: the viability of a white settler state was reliant upon the mobility of white persons, but this movement simultaneously threatened to disrupt established racialised practices and undermine settler cohesion. Largely set in a farming district, the novel has also arguably contributed to the enduring image of white settlement in Rhodesia as a predominantly rural phenomenon. The notion of the fundamentally agrarian nature of white experience has been strengthened in recent years due to the centrality of white farmers 
in struggles over land in Zimbabwe in the early 2000s. This, in turn, has been reflected in the increasing number of studies which have attempted to grapple with issues of belonging, privilege and power in Zimbabwe through a critical framework of whiteness. ${ }^{3}$ The best of this work has been attentive to the complex processes in the creation of white racial identity, has stressed the diversity of the white population, their backgrounds, political beliefs and experiences, and has acknowledged that racial privilege and power is constructed, claimed and performed in different ways across the settler population. ${ }^{4}$ However, much of this work has perpetuated homogenising tendencies evident in earlier Manichaean colonial narratives. ${ }^{5}$ Despite some scholars recognising that land ownership was not the sole or primary foundation of white power and privilege, ${ }^{6}$ the critical literature which has emerged on settlers in recent years has mostly been bounded by a chronological focus on independent Zimbabwe, has been dominated by rural, politically liberal and middle-class whites, and has failed to investigate broader social differentiation amongst settlers.

The Central African Federation period offers historians an opportunity to examine how white identity was created and claimed during a period of increased immigration and expansion. Imperialism was underpinned by the movement of persons, commodities, knowledge, ideologies and cultures, but paradoxically this movement was accompanied by essentialising processes that sought to create fixed racial categories, erect barriers to movement and concretise national and imperial borders. ${ }^{7}$ Rhodesian authorities encouraged European settlement while placing strict restrictions on the type of white settler it allowed in, refusing those it deemed to be either nationally, ethnically, politically or economically "undesirable". 8 Settlers also policed themselves in internal processes of regulation. Established settlers instructed new arrivals in "proper" racialised behaviours and the particular standards demanded of white skin in Southern Africa. ${ }^{9}$ Alison Shutt and Tony King have stressed that the transient nature of the settler population meant that re-education was a constant task. Cecil Rhodes, early frontier myths, hostility to apartheid and promotion of the multiracial franchise as a central part of settler identity became important in the socialisation of new immigrants. Yet the success of this settler socialisation has been overstated. ${ }^{10}$ While settler ideologues stressed a shared culture, politics and way of life in order to highlight the supposed incommensurability of racial groups, restrictions on settlement, processes of internal regulation and pronouncements of racial unity ultimately failed to create a cohesive white community. Alois Mlambo has noted that post-war immigration of middle-class professionals created differences between "Old Rhodesians" and new arrivals with the latter holding relatively liberal racial ideas, preferring paternalist multiracialism than outright segregation and opposition to majority rule. ${ }^{11}$ Donal Lowry has acknowledged migrants with a more conservative outlook who desired to escape the British post-war Attlee Labour government as well as the "Bengal Chancers" and "Poonafontein Rifles" who arrived in Rhodesia from newly independent India. ${ }^{12}$ Nevertheless, historians have paid less attention to the emigration of lower class whites during this period. 
Labour historians of Southern Africa have increasingly interrogated the formation of the highly racialised identities of white workers across Empire and the global processes central to class formation and struggle. ${ }^{13}$ While attentive to the ways in which politics, ideologies and identities were circulated and co-produced within these imperial flows of labour in Southern Rhodesia, the focus of this chapter lies not on the cohesion or common ideology produced by this movement, but in the fragmentation caused by international flows of labour; the ways in which European mobility aggravated divisions within white labour and settler society more broadly. The expansion of certain industries and high turnover of labour meant that new migrants, social groups, ideas and ideologies were continually being introduced into the labour force. These new additions meant that the socialisation of new arrivals into normative behaviours was a continual process; but it also meant that existing white workers' identities, cultures and politics were constantly modified. This chapter probes this dynamism, failed settler socialisation and competing notions of idealised white behaviours through exploring an under-examined strike of European firemen on Rhodesia Railways in 1954. For white railway workers, the railways represented more than the mobility of goods and persons, they also held the promise of upwards social mobility in the settler community. However, many of the immigrants who moved from the UK failed to transcend the borders of class and status they were trying to escape. While the 1954 strike ostensibly emanated over pay and conditions, it was also fuelled by an assertion of certain rights and privileges that framed white workers' identity, including the right to organise. Certainly, the strike and subsequent fallout demonstrates the extent to which the settler government feared that white labour had a latent radicalism which could be stirred into frenzied industrial action; that they could join with African labour or simply give African labour "ideas", and shows that the Rhodesian government was prepared to use considerable force in disciplining white labour if it overstepped established boundaries. As such this chapter supports the contention of Jon Lunn and Ian Phimister that white workers engaged in struggles over the labour process and the organisation of work beyond the formalisation of the colour bar under the 1934 Industrial Conciliation Act, but also militates against the tendency of existing research to present reified, albeit internally differentiated, white worker ideologies, beliefs and cultures by stressing the dynamism of class formation and the ongoing and contested production of white worker identity. ${ }^{14}$

\section{The RRWU}

The 1954 strike was led by dissatisfied members of the largest European trade union operating on the railways, the Rhodesia Railway Workers Union (RRWU).The RRWU had been established in 1916 and sought to unite European men from all grades on the railways but favoured the employment of white British men and struggled against non-British Europeans, European women and most importantly, African men. It attempted to create a hypermasculine 
identity based upon notions of respectability and pride in work and this professed identity was most evident in the RRWU's monthly journal, the Rhodesian Railway Review. The Review reported on local union news, political and economic developments in Rhodesia and the British Empire more broadly, trade union struggles and Labour Party developments in Britain as well as day-to-day railway life, individuals and their successes, deaths, and promotions, news of football leagues, picnics, dinner dances and social functions organised by railway wives. Importantly, the Review also acted as a medium through which the trade union bureaucracy attempted to shape and regulate white worker identity and behaviour. Editorials and articles in the Review most clearly represent the views and attitudes of the trade union bureaucracy. Although on occasion the editors of the Review noted that they had heavily edited or refused to print particular submissions from members that they either did not agree with or found to be libellous, dissenting voices were not entirely erased from its contents. The contestation over trade union politics and white worker identity more generally is evidenced most clearly in its letter pages and from notes written by locally elected branch scribes. This chapter also uses RRWU Conference minutes, internal investigations and correspondence of the Railway Administration, British and Rhodesian newspapers, correspondence between the Federation's British high commissioner and the Commonwealth Office and Southern Rhodesian legislative assembly debates to analyse divisions within white labour as well as the competing responses of British and Rhodesian state officials, employers and the public to the strike and the idealised behaviours of white settlers more generally.

\section{Overview of the strike}

Envisioned as a barrier against majority rule and a route to independence and dominion status by white settlers and African critics alike, the short-lived Central African Federation joined together the Rhodesias and Nyasaland in 1953. The Federation witnessed a period of unprecedented growth. European immigration, African urbanisation and participation in wage labour had dramatically increased during the Second World War and continued apace in the post-war years. ${ }^{15}$ Established labour practices were destabilised by these interrelated phenomena. Struggles over the demarcation of white and black work and the differential racialised standard of living were reflected within industrial action taken by both African and white workers over the period. ${ }^{16}$ In Southern Rhodesia European railway workers had not taken strike action since 1929 and the last significant European strike had taken place in 1932 in the building trade. Significantly, both of these occurred prior to the introduction of arbitration machinery under the 1934 Industrial Conciliation Act, which, alongside formalising the European monopoly of skilled jobs, had effectively prohibited strikes in the colony. The 1929 strike had been seen as the last whimper of a weakened European trade union movement which had faced a concerted onslaught from employers in the early 1920s after a period of successful militancy following the 
First World War. ${ }^{17}$ Despite never fully recovering to its former strength, by the time of the strike in 1954, the RRWU had a membership of 5,728, which represented around three quarters of all European staff employed on the railways north of Bulawayo. ${ }^{18}$

In the lead up to 1954, tensions had been building amongst low paid workers for a considerable period. The RRWU had entered arbitration in February 1953 and while a basic pay increase was won for all grades, the arbitration received a mixed response from RRWU members. In particular, married men claimed they were unable to support their families on basic rates of pay. ${ }^{19}$ The high number of resignations on the railways fuelled the belief that the Administration were bringing out experienced workers with families from the UK under false pretences. For white railwaymen, an appropriate wage was determined just as much by age and marital status as it was by race and gender. The RRWU argued that men with years of experience and skill were being hired in low skilled work..$^{20}$ The existence of this layer of whites failing to attain white standards of living within the railway community threatened to bring down the prestige of railway workers more generally. White workers were keen to present an image of social mobility and respectability which demanded ensuring that every white person employed by the railways was able to project an air of prosperity and achievement. Lower skilled and lower paid positions were often understood to be appropriate only for younger, single men from which they would gradually progress after gaining relevant experience. However, staff shortages had forced the Administration to hire older experienced men in the shunting grade, which was considered a "learner" grade. As a result the fireman's wage of $f^{39}$ per month did not match what many older Europeans expected as a basic rate. ${ }^{21}$

The Railway Administration and RRWU were forced to repeatedly state that the firemen could not take action outside the arbitration machinery and threatened that any man taking illegal strike action would be prosecuted. ${ }^{22}$ Nevertheless, firemen continued to call for strike action and there were calls from some quarters to form a new independent railway union..$^{23}$ As agitation over pay from the firemen's section increased, Charles Robert Taylor, a British trade unionist and fireman who had been resident in the colony for thirteen months, was singled out as a ringleader of the continuing dissent and was expelled from the RRWU on the 31 May 1954. Particularly unnerving to the Administration and the government was the aptitude Taylor had shown in organising and rallying the men. On the first day of the planned strike the CID searched Taylor's house and found what they claimed to be a 'draft manifesto of standard communist type' which provided grounds for his arrest on the 4 June. Another new arrival from Britain, W. Raeburn, was also arrested. ${ }^{24}$ On hearing this news, firemen voted to carry on with the strike at midday on the same day and Taylor was swiftly deported to the UK.

The strike went ahead in spite of interventions by the Railway Administration, the RRWU's executive and the government, and began in Salisbury where it was reported that all but two of the 125 firemen had joined the 
strike. By the 5 June the strike had spread to Northern Rhodesia and police patrolled the railway line near Livingstone after it was claimed that railwaymen had attempted to sabotage the line. However, strike leaders claimed to know nothing of this and 'offered to protect the railway from sabotage if necessary' ${ }^{25}$ At Bulawayo, while fewer firemen were reported to join the strike, rail traffic was reported to be at "a standstill". ${ }^{26}$ While initially consisting solely of firemen, the strike gradually extended to include some sympathetic engine drivers and shunters who were angered by the heavy-handed response. They were particularly ired by the arrests of Taylor and Raeburn and the reaction of the Administration who had automatically dismissed seventy-four of the firemen who had taken strike action. ${ }^{27}$ The firemen refused to negotiate with the president of the RRWU when he met with them to convince them to return to work and demanded separate representation as they distrusted the leadership who had seemingly aided the state to deport Taylor. ${ }^{28}$ Garfield Todd, on the other hand, refused to negotiate with the strikers and would only deal with official RRWU representatives. The strikers eventually agreed to return to work on conditions of no victimisation, a fair trial for Taylor and a special commission into their claims. While strikers at Salisbury eventually agreed to end the strike on the 7 th, men at Bulawayo refused to trust reports of men returning to work from the RRWU leadership and management, and as a result did not return to work until the 10th, only after Salisbury strikers had been flown out to Bulawayo to confirm the reports. ${ }^{29}$

\section{Explanations of the strike}

The Administration, RRWU executive and the rank and file provided competing explanations as to the strike's causes. Management maintained that the ringleaders of the strike had no concerns over firemen's pay. ${ }^{30}$ They were accused of taking advantage of ill feeling in order to have a holiday, and it was noted that it was not entirely 'irrelevant that [the] strike came day or two after payment of wages for May and coincided largely with Whitsun holidays' ${ }^{31}$ The RRWU Executive Committee asserted that the initial 1953 arbitration had been generally successful and claimed that despite winning concessions and pay rises for some of the men, the firemen would not listen to "reasonable argument". 32 Two Executive Committee members described their own attempt to intervene in a meeting of firemen to persuade them not to strike:

One [fireman] had got up and said: 'Mr. Adams and Mr. Longden have persuaded us that we are wrong, but it is too late. Tomorrow we strike. Don't we chums?' and they had said yes. They would not listen to reason; the strike had all been arranged. ${ }^{33}$

The RRWU leadership repeatedly described the behaviour of the strikers in ways which served to create an image of an injudicious, malleable mob. The men, it was argued, had no real grievance but had been riled up by Taylor and 
his communist propaganda. Taylor was portrayed as a demagogue who did not care about the firemen's concerns and never turned up to branch meetings, but who was obsessed with striking and had deviously tricked the men into his own agenda which included ousting the general secretary and appointing himself as leader. ${ }^{34}$ Although Charles Taylor received support from the British National Union of Mineworkers and other trade unionists in Britain who had written to the secretary of state for the colonies to protest Taylor's treatment, solidarity within Southern Rhodesia was less forthcoming. Certainly, many in the RRWU did not only refuse to support Taylor but actively cheered his deportation. The rapidity with which Taylor was deported without trial emanated from deep-seated fears of the Administration and government that white workers could hold the country hostage through paralysing the railways. The strike was repeatedly framed in the Rhodesian press as an attack on Rhodesia itself. Addressing the annual congress of the British Empire Service League, Garfield Todd urged the audience to 'fight the foe within our borders' and declared that the strike had followed a 'communistic pattern'..$^{35}$ The government belatedly justified the deportation on the basis that Taylor had lied to enter the colony; Taylor's wife had confirmed he had been a member of the British Communist Party from 1943 to 1953 and a propaganda secretary for a local branch in Derbyshire, all of which were used to discredit Taylor and the firemen's demands. ${ }^{36}$

The fireman's strike had received widespread coverage in the British press. In the Daily Worker Taylor warned that

Rhodesian reactionaries haven't heard the last of Charles Taylor. I shall do my best to tell as many British trade unionists as I can about conditions in Rhodesia. I promised the lads I left behind that I would do this, and do it I will. ${ }^{37}$

The publicity that Taylor had garnered in his defence was seen as having the potential to jeopardise essential recruitment of skilled workers from the UK. Taylor had returned to Britain and openly challenged the myth of social mobility in Rhodesia. He hit back at the RRWU leadership as 'smug and lazy', accusing them of ignoring the rank and file and effectively acting as part of management rather than as the representatives of labour. According to Taylor, part of the reason why firemen took action was due to the Administration's offer for improved conditions being restricted to the "UK men", while Afrikaans speaking men who made up half of the frontplate staff were offered no improvements. Taylor described the offer as a "disgraceful" suggestion which "would have worsened racial feeling and destroyed all hopes of unity for a generation' and he cheered that when the strike eventually came, UK and Afrikaans men walked out together. Taylor also vocally criticised the conditions of Coloured prisoners in the Cape where he was stationed before deportation to Britain. He described the prisoners being 'stripped and whipped with metaltipped canes' as 'the most degrading sight I have ever seen'. ${ }^{38}$ He publicised 
that men were in debt and that new arrivals were disgruntled at their low pay and often 'did not know where their next meal would come from'. Taylor further described his own experiences in damning terms: "one day I did the unmentionable thing in Rhodesia: I borrowed money from my "houseboy" to buy milk for the kiddies'. ${ }^{39}$ Taylor understood that he was contravening white standards of behaviour and offered a view of reliance and dependence upon African domestic staff; an image Rhodesian white labour had put considerable effort into emphatically denying.

The Executive Committee used anecdotes of Taylor's communism and liberal racial attitudes to justify their actions towards the strikers and attempt to erode the fireman's loyalty to him. Mr. Beirowski, a Salisbury delegate at the 1954 RRWU Annual Conference, recalled that he had met Taylor in the Zawi mess room where Taylor was talking about the recent strike of Africans at Wankie and had denounced the Government's actions to break the strike. Beirowski reported that he had challenged Taylor and asked, 'Do you realise what you are saying as regards the African? Do you want the African to upset the country like that and just do as he likes, violence and breaking the law and acting illegally?'Yet according to Beirowski, Taylor had continued to defend the rights of Africans to strike and even declared that 'my views about the African are these. When my daughter grows up, if the African is fit to have my daughter, he can have my daughter'. ${ }^{40}$ Protecting white women was an axiomatic element of white masculinity within Rhodesia. By symbolically offering up his own daughter to an African man, Taylor had transgressed a constitutive element of settler manhood. Notably, it was not the physical occurrence of interracial sex which was being denounced by Beirowski, but rather Taylor's utterance of its acceptability. Taylor's beliefs and attitudes were as much on trial as his actions. As research into the production of settler boundaries has shown, settler colonial states desired not just to regulate the behaviour of their subjects; but to make them 'think and feel' in particular racialised ways. ${ }^{41}$ Taylor clearly knew the accepted boundaries of racialised interaction, recognising that his borrowing money from his servant was "unmentionable", yet he did not feel requisite humiliation to hide this transgression; neither did he apparently shy away from public declarations of support for interracial sex or African militancy. Whereas Lessing's Tony Marston was successfully shamed into silence by established settlers over the relationship between a white woman and African that he had seen, it was precisely Taylor's lack of shame or sense of racial propriety which marked him out as dangerous. For the RRWU, their broader reputation was at stake by being seen to tolerate such views; Taylor was recognised 'as a serious threat to union prestige'. ${ }^{42}$

Taylor's refusal to act in ways expected of white men in Rhodesia was directly linked to his previous political association with the CPGB. Anti-communism was a central tenet of white Rhodesian political ideology throughout the period of minority rule. ${ }^{43}$ The 1922 Rand Revolt in South Africa made a lasting impression in white Rhodesia. In the first decades of settlement, white workers and trade unions were repeatedly accused of revolutionary communism 
by employers, MPs and the press. ${ }^{44}$ One of the first general secretaries of the RRWU, Jack Keller, was nicknamed the 'Lenin of Rhodesia' and European trade unions and the Rhodesia Labour Party had to repeatedly state that they harboured neither communist nor Bolshevist sympathies. ${ }^{45}$ This fear of white labour upheaval and international Bolshevism never entirely dissipated. During the Second World War the presence of European servicemen, refugees and enemy internees heightened suspicion of communist infiltration. ${ }^{46}$ When Communist Party recruitment propaganda surfaced in the colony during the late 1940s, it was blamed upon the increasing presence of "newcomers". ${ }^{47}$

Communist ideas were dangerous not only because of the wider Cold War context and threat of industrial upheaval, but because they were perceived to encourage the erosion of racial boundaries. The propaganda which surfaced during the 1940s was particularly reviled as it embodied 'the dangerous peculiarities of the communistic thinkers ... they are firm believers in equality of race and colour' ${ }^{48}$ The presence of communist individuals was thus seen as having a wider corroding effect on the racial order of settler society. Racial thinking had to be learnt and while white labour's structural position engendered animosity towards black workers and inhibited the likeliness of solidarity, such racial attitudes could not be taken for granted. The newcomer who had not yet been adequately drilled in the racial protocols expected of Rhodesian labour had to be prevented from diluting the union's attitude to African workers. This in part reflected dominant ideas that established settlers had intricate ways of knowing the African population unobtainable to the newly arrived settler. This was reiterated by many new arrivals. Sam Wright, a railwayman employed from 1950 to 1976, acknowledged that while recent settlers could achieve amicable relations with Africans they 'never quite had the same association as those African born' who possessed an 'insight into the ways and nature of the Africans'. Wright commented that the more recent immigrants displayed an 'unfortunate variety of attitudes' with complete disregard for the 'boundaries of personal contact that was acceptable'. Unlike the established settler, newcomers did not understand the full implications and 'dangers of too much familiarity which was not to the comfort of either party'. ${ }^{49}$

Accusations of communist ideas taking root amongst white workers may have been informed by real fears, but there is no evidence for widespread communist sympathies amongst the white workforce. The strike had not been universally supported amongst rank and file railwaymen and some railway staff actively tried to break the strike. The Administration reported that virtually all clerical staff at Salisbury had volunteered to take on firemen's duties and an appeal for volunteers had also attracted a substantial response from the public. ${ }^{50}$ Moreover, liberal racial ideals found little receptive audience in the wider white worker community despite broader fears amongst settlers over the erosion of racial boundaries. When an Executive Committee directive ordered that white drivers should work with unqualified firemen to break the strike, it was vociferously condemned as an attack on the colour bar. Initial reports sent between railway management suggest that railway authorities were keen not 
to use Africans to perform work usually done by Europeans as they feared it would strengthen the strikers' resolve and garner support for their action from other sections of the European workforce. However, rank and file members accused the Executive Committee of giving 'the right to the Administration to place any human being of any colour on an engine and call him a fireman'. One delegate to the 1954 RRWU Conference argued in defence of the union that their role was to break up illegal strikes:

it even warranted the use of European convicts on the footplate. Everybody would have been done out of a job. There was also the example to the African. They were putting it in their heads how to get rid of all Europeans in the country; if the illegal strike had been successful they would have "had it". ${ }^{51}$

Threats of African industrial action could be used to discipline white workers, but also offered white labour opportunities to coalesce around race. ${ }^{52}$ Despite division between occupations, blue collar and white collar workers, skilled and unskilled trades, white workers could unite out of racialised solidarity when challenged by African workers. After an inadequate basic wage increase in 1956, the Railway African Workers Union (RAWU) called a strike which saw 7,500 Africans lay down tools for three days. ${ }^{53}$ Police were armed with truncheons and used tear gas on striking Africans who had gathered in Bulawayo. ${ }^{54}$ Bulawayo Branch admitted candidly that 'it has been our duty to do everything in our power to keep the job going which is nothing less than breaking the strike' and accused RAWU of putting its members at risk. ${ }^{55}$

Nevertheless fears of trade union militancy and the erosion of racial boundaries persisted. Rhodesia was seen as fertile ground for radicalism to take root and this was due, in part, to the transience of its settlers. The RRWU leadership argued that new arrivals had not fully adjusted to the Rhodesian trade union modus operandi or settler culture more generally, and were much more willing to revert to strike action. ${ }^{56}$ Management likewise reasoned that the cause of the strike was down to mass recruitment of new European staff. In 1954, of the 8000 Europeans employed by the railways, 5,200 had less than eight years of service. Although recruits were screened, management admitted that with their huge recruitment drive it was inevitable 'that some of the less desirable found their way into the country'. They further noted that

it was apparent for some time that many overseas recruits were fairly strongly influenced by socialist ideas and felt that labour should negotiate on more militant lines. This feeling among certain grades of recruits goes back some years. ${ }^{57}$

Sam Wright recalled that employees recruited from Britain were 'the most vociferous, in union matters . . . it was a constant ding-dong between them and management' ${ }^{58}$ European immigration was intended to maintain racialised 
employment practices and ease skilled labour deficits, but this was conditional on new arrivals being socially mobile and on being able to perform a particular imagined white identity. The social mobility that Rhodesia promised its white workers was embodied in figures such as Roy Welensky who had risen from a position as a railwayman to the premiership. But this social mobility was neither universal nor automatic. In the year of the strike the Women's Guild had dispensed Government rations of $1 \mathrm{~s} 6 \mathrm{~d}$ per person to 16 European families and 29 Coloured families every month for the preceding year. A further 96 European families and 74 Coloured families were given secondhand clothes and shoes by the Guild. ${ }^{59}$ In a bid to prevent radicalisation the Railway Administration set up a welfare fund for its European staff in 1956, whose purpose was 'to give assistance for the relief of distress amongst railway employees by means of loans or grants in cash or kind', and in its first year dealt with 1,532 cases of white distress. ${ }^{60}$ By 195728 percent of all European employees were approaching the Administration for financial assistance. ${ }^{61}$ From these statistics it is unclear what qualified as "distress" for European workers: whether this was an inability to provide for dependents, to pay African domestic staff, or to attain a social standing befitting of white skin. What is clear however is that many white workers felt themselves to be in a position of distress and invested in the idea that they impecuniously existed at the edges of white propriety.

To militate against continuing dissent, as well as initiating more stringent screening processes, it was suggested that railwaymen be forbidden from marrying until they had reached a certain wage, something which was already in place for army personnel, policemen and bank employees. ${ }^{62}$ This, it was thought, would prevent the growth of impoverished families and dissatisfaction from married employees. The Department of Labour likewise expressed a preference for men to come out individually and establish themselves before bringing out their families as the infrastructure could not bear added population. ${ }^{63}$ Without the requisite housing and services, white recruits were living in conditions below what they had anticipated and as a result were seen as being more susceptible to communist influences and involvement in industrial action. The settler state, Railway Administration and RRWU itself desired the settlement of white families; families were seen to engender stability and permanence. Yet economic conditions meant the immigration of families had a potentially radicalising effect and discontent surfaced when expectations of upwards social mobility failed to materialise.

Some strikers admitted that their primary concerns were not about pay. At Dett, railwaymen listed demands about street lighting, water shortages, shortages of electrical appliances and home conditions. They specifically complained about their Nursing Sister, who had caused a 'certain amount of friction' due to the fact she was 'of a type above the average driver, fireman and guard and does not socially mix too well' ${ }^{64}$ In a similar vein, Sam Wright, while usually at pains to emphasise uniformity amongst Europeans on the railways 'in skills [and] social sophistication', was forced to admit that 'dotted in this rather homogenous crowd, were a few exceptions who stood out a bit like sore 
thumbs'. Those he noted as standing out were not the poor, but those from the 'higher class of society', one a "pompous" superintendent and another a doctor, scarred from "duelling", who walked around "with such an air of conceit and self-importance as to become a figure of ridicule and mockery'. ${ }^{65}$ Jon Lunn has fruitfully used the notion of the bailiwick - the area in which workers could assert their limited authority and independence within wider systems and boundaries - and argued this space should be understood as a fundamental area of expression for white worker identity in which gendered and racial hierarchies were enforced. ${ }^{66}$ Railway workers attempted to influence railway spaces by controlling the movement and presence of particular racial and classed groups. Railways enabled settlement, influenced social identifications and produced hierarchies of labour in which racial status was constructed and proclaimed. Carriages and platforms marked out boundaries of class, race and gender and were sites of struggle over social identities. ${ }^{67}$ Numerous complaints over an unwanted African presence littered the Review and the managementfunded Rhodesia Railway Magazine which described 'hordes of Africans, their beds, furniture and possessions that are daily to be found scattered all over the station' and 'the hordes of "loafers" who sprawl all over the station premises at all hours of the day and night' ${ }^{68}$ Demands for separate African, Coloured and white railway stations and carriages abounded. ${ }^{69}$ Physical distance and separation reinforced claims to particular racial identities, but this animosity extended to upper class whites. Railwaymen attempted to cultivate the railways as a white space; but it was also fundamentally a classed space. The white families of the Dett railway community were angered by a middle and upper-class incursion into their delineated communities. Just as Charlie Slatter despised the middleclass accoutrements of Tony Marston in The Grass is Singing, on the railways the presence of such figures was a reminder of many railwaymen's social inferiority and the class divisions that many were trying to transcend, but also pointed to the limitations of white social integration and an inclusive Rhodesian identity. ${ }^{70}$ Workers at Dett attempted to utilise the strike action to set forward their own demands regarding the white railway community and who was and was not a part of it.

\section{Disciplining white workers}

The strike itself was also a reaction to the treatment of Taylor; this was an assertion of the right to organise and a flagrant challenge to the RRWU leadership. There was particular anger over the perceived heavy handedness of the state in squashing the strike. The government argued that they could not let a European strike continue especially as they had acted with brutal force against recent African strikers at Wankie. ${ }^{71}$ Within hours of the firemen announcing their strike, a state of emergency was declared across the colony. The CID searched the homes of strike leaders and several were arrested, dismissed from the railways, or subsequently demoted. Jack Keller, former president of the RRWU and member of parliament for the railway constituency of Raylton for 
the Rhodesia Labour Party since 1928, openly criticised the RRWU leadership and complained of "gangster" tactics claiming that Garfield Todd and Roy Welensky had descended on his home to interrogate him and his links to the strikers. ${ }^{72}$ He claimed strikers had been "shadowed" by the CID, that letters sent to the Rhodesian press in support of Taylor were suppressed and that his own phone line had been tapped by the state. ${ }^{73}$ Keller outlined his treatment and accused Rhodesia of being a one-party state in a letter he sent to a number of British media outlets and statesmen including the BBC, Clement Attlee and Winston Churchill. More broadly, in the Legislative Assembly, Keller used the strike to curb state powers against white workers. Specifically he moved a motion to repeal section 8 of the Peace Preservation Act which allowed the governor to make regulations in the event of strikes. The Act allowed the Government to pass laws without parliament; to use forced labour, to hold people without trial, and to arrest without warrant 'anyone whom they suspect ... merely suspect - of having said or done something which might in their opinion adversely affect the efficiency of an essential industry'. ${ }^{74}$ Keller denounced the Act as a fascist decree and claimed Rhodesia was a police state, reminding the Assembly that he had been assured that under no circumstances would the Act be used against white workers. ${ }^{75}$ Presumably he believed such measures were necessary to deal with industrial action involving African workers, but impinged on the civil liberties of Europeans. The Legislative Assembly upheld that the Act should be used against both black and white workers in the interests of "freedom". Europeans could not be seen to be openly flouting the law, and punishment had to be meted out. ${ }^{76}$ All union power had to be curbed and wildcat strikes in particular could not be tolerated. Europeans had a price to pay for their privileged position in the labour market. One MP reminded white labourers that:

The European artisan is not only in a specially favoured position under the law but he also in consequence has special duties to the community in which he lives ... in the presence of an almost overwhelming mass of uncivilised and unskilled labour [his duty] is to act moderately and temperately in industrial disputes. ${ }^{77}$

In the past public opinion had been mobilised against white industrial action through allusions to African rebellion. Employers, the government and the press had variously argued that white strike action was the height of irresponsibility; it not only threatened white unity but encouraged Africans to rebel against their bosses. ${ }^{78}$ Now the RRWU trade union bureaucracy also declared that strikes were counterproductive due to their potential influence upon African workers. ${ }^{79}$ They accepted principles of arbitration and came down heavily on any action outside its direct control. Yet what this episode demonstrates is precisely a lack of control over white labour on the railways. Many white workers were failing to display the outward signs of respectability which the RRWU strove to project. The Review condemned railway employees' behaviour noting 
that 'the managers and European staffs of some canteens have been insulted; African servants have been assaulted; furniture and equipment have been broken, and utensils have disappeared at an appalling rate' ${ }^{80}$ Letters to the Herald bemoaned the high expectations of new arrivals and pointed to the fact that the firemen's wage reflected its low skill. While these newcomers would have had a lowly status in Britain 'governed simply by the type of trade in which they were employed, not by the colour of their skin. After a spell in the colony it beats into their brains that they are Europeans and must therefore enjoy this so-called European standard of life'. ${ }^{81}$ Dissatisfaction was seen as a consequence of new arrivals' unrealistic expectations. Another letter expressed shock at the behaviour of new immigrants and asked 'if they are not satisfied then why do they stay, and upset others?' 82 The accused 'lawlessness and irresponsibility' of Taylor, argued one letter, amounted to 'the negation of those qualities which we term British' ${ }^{83}$ Those defending Taylor on the other hand argued that the way Taylor had been treated 'smacks of fascism' and was decidedly "unBritish". ${ }^{84}$ Within Rhodesia established settlers and newcomers offered competing definitions of who was, and who was not, authentically British. Accusing others of not being British was a way of positioning one's views and beliefs as a legitimate expression of "Britishness" while marking others out as fraudulent or degenerate, but also points to the importance of this national identity in broader settler identification. ${ }^{85}$ These contests over British identity demonstrate competing claims to a superior character, politics and way of life which were themselves rooted in different class experiences; class divisions continued to undermine any sense of a cohesive racial and national identity.

\section{Reasserting control over the rank-and-file}

In the wake of the strike the RRWU Executive's assertions of confidence and moves towards providing financial assistance to Europeans at the bottom of the wage scale failed to quell dissent. The close relationship between employer and trade bureaucracy fostered by the Industrial Conciliation Act was coming under greater scrutiny from rank and file members. While in the first decades of the twentieth century the trade union bureaucracy of the RRWU was considered to comprise the most radical and politically engaged section of white workers in contrast to a supposedly apathetic rank and file which lacked political education, ${ }^{86}$ by the 1950 s trade union bureaucracies were regarded as increasingly conservative and a barrier to militant action by sections of white labour. Large sections of the rank and file were also seen as failing to meet the standards of white respectability demanded by trade union leaders.

The general manager of Rhodesia Railways and the chief industrial officer of Southern Rhodesia were present at the RRWU Conference and congratulated the RRWU leadership and its role in bringing the rank and file into line. The chief industrial officer further noted that the behaviour and respectability had generally improved due to the 'grandfatherly attitude towards the youngsters ... you put the lads in their places'. ${ }^{87}$ The RRWU bureaucracy had built 
an image of respectability based upon partnership with employers and the state. White monopoly of skilled jobs and racially exclusive trade unionism were justified through a language of responsibility and rights that white workers had earned through jettisoning radicalism and embracing conciliation. This close relationship and regulatory role taken by the RRWU leadership did not go unnoticed by rank and file members. There were reports of raucous meetings full of insults and jeering towards officials, and editorials in the Review were forced to repeatedly extol the virtues of the current leadership and list their accomplishments in fighting for improved conditions. ${ }^{88}$ Branch scribes, on the other hand, continued to submit notes to the Review which defended Taylor and denounced the leadership. The strike, in their opinion, was not a result of Taylor's interference but of 'bureaucratic administration . . . allied with clueless but abundant supervision on the part of many junior officials' ${ }^{89}$ Branches also accused that the incumbent leadership had caused a wave of resignations from the union. ${ }^{90}$ The union bureaucracy in turn accused the branch scribes of disruption and of the 'flouting of authority', but the dissatisfaction failed to subside. ${ }^{91}$ A year on, Que Que Branch continued to call for a special conference and a motion of no confidence in the Executive Committee. ${ }^{92}$ Despite the RRWU's 1954 annual conference passing several motions of confidence in the union leadership, branch scribes complained that delegates had voted against the prevalent feelings of their branch members. Certainly, transcripts of the motions and debates held at the conference reveal that many elected officials feared being held accountable by the rank and file members. One delegate made an impassioned plea in support of a motion which attempted to make conference voting anonymous as 'in some instances if how he voted were to become known to his branch his life would be miserable'. ${ }^{93}$ The motion was lost but nevertheless reveals that some trade unionists did not see their roles as representing the wishes of their branch members, but as one of instruction and regulation.

During the 1954 Conference there were several failed attempts to remove this conservative layer from the union leadership. Lower grades in the union were keen to prohibit railway officials - including inspectors and instructors from serving on the Executive Committee, under the contention that these higher grades were effectively working as part of management. The motion was lost by nine to fourteen. ${ }^{94} \mathrm{~A}$ motion to reduce the number of years a man had to be part of the union to be elected to the NIC from five to three years was likewise summarily rejected by the conference. In a revealing defence of the stipulation, one National Committee member asserted that lowering the number of years would introduce 'foreign elements to disturb and distract them' as it took more than five years 'to become really domiciled as a Rhodesian'. ${ }^{95}$ Here, Rhodesianness and trade union principles were acquired through fixity; being sufficiently settled was a prerequisite for acquiring responsibility. Notably such notions of rootedness were also utilised in justifications of differential wages; white demands for higher wages were made through reference to European monopoly of skill and a white standard of living which was underpinned by 
stress upon the permanence of white employees in contrast with the supposed transitory and seasonal nature of African labour which allowed them to be paid 'single man's wages', despite the long-term service and urban residence of many African employees. Where a person settled also proved important. To rise to the upper echelons of the RRWU bureaucracy a man had to live and work in Bulawayo. Despite disquiet over the dominance of Bulawayo, a motion to incorporate four more members from elsewhere in Southern and Northern Rhodesia was narrowly lost by two votes. ${ }^{96}$ In this way, the union sought to control the potentially radical elements of its membership. They recognised that this meant that many delegates to the NIC were disliked and not the first choice of its members but the RRWU leadership saw this as a necessary measure to prevent newcomers with dangerous ideas from holding positions of power in the union. Not all white workers were deemed to be fit representatives of Rhodesian labour. In particular, the RRWU sought to control infiltration from communists and militant trade unionists, but it also attempted to enforce a particular racialised respectability amongst its members. In both regards, it was only ever partially successful.

\section{Conclusion}

Railways have played a central role in forging new kinds of mobility and in articulating colonial identities. They increased the mobility of persons, goods and ideas which enabled empire and simultaneously disrupted the borders and the production of difference central to the imperial project. The mobility afforded to particular Europeans to traverse imperial locations destabilised established colonial practices and frustrated labour organisations' attempts to cultivate a coherent white worker identity. The white labour upheavals during the period of Federation reveal the general weakness of a divided labour movement, but also points to the ongoing struggles to determine the boundaries of a "white standard of living". It is clear that despite the existence of the colour bar and a series of racialised welfare measures, not to mention the huge wage disparities between African and European workers, substantial numbers of white workers continued to see themselves as hard done by and living either in or on the edge of poverty. Sections of white settlers had failed to achieve the elevated social status they expected through their racial identification. While European workers had a privileged position in the labour market, this was in exchange for a regulated apathy and hamstrung trade union power. For employers and state authorities the use of repressive force was not out of the question; policing settler boundaries was a constant process.

Doris Lessing would be deported from South Africa and declared a prohibited immigrant by Rhodesian authorities two years after Charles Taylor was forcibly returned to the UK. Like Taylor, she was vilified not only because of her political leanings and attitudes to race, but because she had highlighted the hypocrisies of white society, the poor whites the settler state tried to hide from sight and, perhaps most damagingly, written explicitly about interracial sex and 
white women's sexual desire. Performing symbolic practices of differentiation was an essential part of maintaining the racial order. ${ }^{97}$ Lessing and Taylor not only failed to think and behave in properly racialised ways, but actively popularised their transgressions. These thoughts, ideas and actions were envisioned to endanger the very racial boundaries which underpinned settler rule. In the broader context of decolonisation and anti-colonial nationalism, Rhodesian authorities sought to strictly control the movement of radical ideas within its borders. The Rand Revolt had made a lasting imprint; white workers could be stirred into frenzied radicalism and were capable of inspiring widespread revolt amongst Africans. Certainly, Taylor was not the first white worker to face deportation for militant trade union activity in Southern Africa. ${ }^{98}$ Pronouncements on Taylor became a medium through which wider fears over the frailty of settler power were expressed. The RRWU expected white male workers to act in ways that supported internal boundaries of difference; but these behaviours did not occur automatically and white trade union bureaucrats struggled to control their members and cooperated with the state to remove undesirable elements from their ranks. However, the notion of what constituted acceptable white behaviour was not simply imposed from above. Neither were the boundaries of whiteness completely obvious or uncontested. Competing ideas over appropriate racialised behaviours, wages and standards of living were central to the ongoing class struggles over white identity and privilege in Rhodesia.

\section{Notes}

1 Lessing, The Grass is Singing, 13, 180.

2 Ibid., 21-26.

3 See Pilossof, Unbearable Whiteness of Being; Kalaora, 'Madness, Corruption and Exile'; Law, 'Mostly We Are White and Alone'; Alexander, 'Orphans of the Empire'.

4 Pilossof, 'Reinventing Significance', 141-142. For further criticism of the homogenisation of whites in Zimbabwean history see Hartnack, 'Whiteness and Shades of Grey'.

5 McDermott Hughes, Whiteness in Zimbabwe, 5; Fisher, Pioneers, Settlers, Aliens, Exiles.

6 Pilossof and Boersma, 'Not all Whites are Farmers'.

7 Roque, 'Race and the Mobility of Humans', 608-609; Ballantyne, 'Mobility, Empire, Colonisation', 35; Barnes, 'Control of African Women's Mobility'.

8 Mlambo, 'Some Are More White Than Others'.

9 Kennedy, Islands of White.

10 Shutt and King, 'Imperial Rhodesians'.

11 Mlambo, 'From the Second World War to UDI', 77.

12 Lowry, 'Impact of Anti-Communism', 172-173.

13 Bonner, Hyslop, and van der Walt, 'Rethinking Worlds of Labour'; Hyslop, 'The Imperial Working Class'; Money, 'The World of European Labour'.

14 Phimister, Economic and Social History of Zimbabwe; Lunn, Capital and Labour, 10-11.

15 Raftopoulos, 'Nationalism and Labour in Salisbury', 81-85; Brand, 'Politics and African Trade Unionism', 89.

16 Money, 'The World of European Labour'; Phimister, 'Lashers and Leviathan'.

17 'Editorial', Rhodesian Railway Review, March 1929, 8-16. Phimister, Economic and Social History of Zimbabwe, 190. National Archives of Zimbabwe [hereafter NAZ], S480/1460, Strikes and Labour Disputes among Railway Employees, 1926-1929: Memorandum, 21st February 1929, 1. 
18 There were 5728 RRWU members in Northern and Southern Rhodesia in 1954 and 7846 Europeans were employed north of Bulawayo in the same year, Rhodesia Railways Report of the General Manger, for the Year Ended 31st March 1954, 2.

19 'Arbitration Award', Rhodesian Railway Review, April 1954, 1.

20 RRWU Conference, 1954, 25.

21 The National Archives, London [hereafter TNA], DO 35/4831, Deportation of Charles Taylor: SECRET: Inward Telegram from High Commissioner of Federation to Commonwealth Relations Office.

22 'Firemen Told: Illegal to Strike at This Stage', Rhodesia Herald, 21 May 1954, 13.

23 'Railwaymen Give Notice to Union, Que Que', Rhodesia Herald, 4 June 1954, 1; 'Mr Went's Resignation Demanded', Rhodesia Herald, 3 June 1954, 1.

24 '2 Britons Arrested', Newcastle Journal, 7 June 1954, 5.

25 'Rhodesian Rail Strike Chief Under Arrest', Coventry Evening Telegraph, 5 June 1954, 3. Daily Herald (UK), 9 June 1954, 2.

26 'Deportation Move Extends Rail Strike', Birmingham Daily Post, 7 June 1954, 16.

27 '2 Britons Arrested', Newcastle Journal, 7 June 1954, 5.

28 Bulawayo Railway Museum Archives [hereafter BRMA], SD16: Strike, Firemen. 1954. Rhodesia Railways Letters, Press Cuttings, Etc. Letter to Chief Mechanical Engineer, 16th June 1954, no.368/33, 2.

29 TNA, DO 35/4831, Deportation of Charles Taylor: SECRET: Inward Telegram from High Commissioner of Federation to Commonwealth Relations Office.

30 BRMA, SD16: Strike, Firemen. 1954. Rhodesia Railways Letters, Press Cuttings, Etc. REPORT, 2.

31 TNA, DO 35/4831, Deportation of Charles Taylor: SECRET: Inward Telegram from High Commissioner of Federation to Commonwealth Relations Office.

32 'The Firemen and Their Drastic Action', Rhodesian Railway Review, June 1954, 5-7.

33 RRWU Conference, 1954, 227.

34 Ibid., 224.

35 'Southern Rhodesia Strike led by a Briton', Coventry Evening Telegraph, 7 June 1954, 8.

36 TNA, DO 35/4831, Deportation of Charles Taylor: Inward Telegram to Commonwealth Relations Office: From UK High Commissioner in the Federation of Rhodesia and Nyasaland.

37 Taylor, 'Why I Was Deported from Rhodesia', Daily Worker, 6 July 1954.

38 Ibid.

39 Ibid.

40 RRWU Conference, 1954, 222.

41 Jackson, 'Bad Blood'; Stoler, Race and the Education of Desire. For more on interracial sex in Southern Rhodesia see McCulloch, Black Peril, White Virtue.

42 TNA, DO 35/4831, UK Commissioner to Commonwealth Relations Office, 31 May 1954.

43 Lowry, 'Impact of Anti-Communism'.

44 'Strike Tactics', Rhodesia Herald, 23 December 1919, 13; 'Editorial', Rhodesia Herald, 30 December 1919, 13.

45 'The Strike Deadlock', Rhodesia Herald, 23 December 1919, 5.

46 See Tavuyanago, Muguti and Hlongwana, 'Victims of the Rhodesian Immigration Policy'; Rupiah, 'Internment Camps and Refugee Settlements'.

47 Letters to Editor, 'Communists and the Natives: Party Not Wanted in Colony', Rhodesia Herald, 26 March 1948, 11.

48 Ibid.

49 Wright, Tracks Across the Veldt, 45-46.

50 'Rhodesia Rail Strike', Belfast News-Letter, 7 June 1954, 4.

51 RRWU Conference, 1954, 230.

52 See Phimister,'Lashers and Leviathan', 189-191.

53 Rhodesia Railways Report of the General Manager, for the Year Ended 31st March 1957, 14.

54 Ranger, Bulawayo Burning, 202. 
55 'Bulawayo no.1 Branch Notes', Rhodesian Railway Review, October 1956, 13.

56 RRWU Conference, 1954, 210.

57 BRMA, SD16: Strike, Firemen. 1954. Rhodesia Railways Letters, Press Cuttings, Etc. REPORT, 1.

58 Wright, Tracks Across the Veldt, 47.

59 'Work of Guild of Loyal Women for Salisbury's Needy Families', Rhodesia Herald, 1 May 1954, 3.

60 Rhodesia Railways Report of the General Manger, for the Year Ended 31st March 1957, 11-12.

61 Ibid., A total of 2781 employees had approached the railways in 1957.

62 RRWU Conference, 1954, 25.

63 TNA, LAB 13/204, 1820 Memorial Settlers Association, Requisitions: Southern Rhodesia.

64 BRMA, SD16: Strike, Firemen. 1954. Rhodesia Railways Letters, Press Cuttings, Etc. Letter to Chief Mechanical Engineer, 16th June 1954, no.368/33, 3.

65 Wright, Tracks across the Veldt, 34, 87.

66 Lunn, Capital and Labour, 85.

67 Bear, Lines of the Nation; Butcher, The British in Malaya; Aguiar, Tracking Modernity.

68 Black, 'Over to You', Rhodesia Railways Magazine, March 1954, 40, Bulawayo. See 'Over to You', February 1954, 38; March 1955; October 1955, 48, for more examples of complaints over African presence at railway stations. Or from December 1955, 62, demands from 'Bulawayo' for apartheid to be implemented across all stations.

69 Black, 'Over to You', 50.

70 Lessing, The Grass Is Singing, 180.

71 TNA: DO 35/4831 Deportation of Charles Taylor: SECRET: Inward Telegram from High Commissioner of Federation to Commonwealth Relations Office.

72 TNA, DO 35/4831, Deportation of Charles Taylor: Letter from Keller and Storey, 1. Southern Rhodesia Legislative Assembly Debates, 968-972.

73 TNA, DO 35/4831, Deportation of Charles Taylor: Letter from Keller and Storey, 2.

74 Southern Rhodesia, Southern Rhodesia Legislative Assembly Debates, 919.

75 Ibid., 940.

76 Ibid., 956.

77 Ibid., 942-946.

78 Kennedy, Islands of White, 139. For examples of white trade union militancy and organisation influencing African workers see Phimister, 'An Emerging African Proletariat', 61; Lunn, Capital and Labour, 130; Ranger, Bulawayo Burning, 51-52.

79 RRWU Conference, 1954, 211.

80 'Editorial: Our Canteens', Rhodesian Railway Review, March 1952, 2.

81 Toothpick, 'Payment on Results', Rhodesia Herald, 7 June 1954, 5.

82 Contented Citizen, 'Wages on the Railways', Rhodesia Herald, 2 June 1954, 7.

83 'Todd's Warning on Communism and Federation', Rhodesia Herald, 7 June 1954, 1.

84 TNA, DO 35/4831, Letter from R.J. Scott to Mr. Champion MP; Letter from Keller et al. sent to Winston Churchill, Clement Attlee, General Secretary of the Transport and General Workers Union, and various British newspapers.

85 See Schwarz, White Man's World, 398.

86 Jon Lunn argues that the RRWU bureaucracy were more radical than the rank and file, Capital and Labour.

87 RRWU Conference, 1954, 3.

88 'Salisbury no.1 Branch Notes', Rhodesian Railway Review, June 1954, 6; 'The Union's Case Summed Up', Rhodesian Railway Review, September 1954, 12.

89 'Bulawayo no.1 Branch Notes', Rhodesian Railway Review, September 1954, 15. For more criticisms of leadership and support of firemen's strike see, 'Choma Branch Notes', Rhodesian Railway Review, October 1954, 20; 'Salisbury no. 1 Branch Notes', 23; 'Bulawayo no. 4 Branch Notes', Rhodesian Railway Review, June 1954, 24. 
90 'Que Que Branch Notes', Rhodesian Railway Review, October 1954, 22.

91 'The Union's Case Summed Up', Rhodesian Railway Review, October 1954, 7.

92 'Que Que Branch Notes', Rhodesian Railway Review, July 1955, 22.

93 RRWU Conference, 1954, 11.

94 Ibid., 251-255.

95 Ibid., 244.

96 Ibid., 248-249.

97 Kennedy, Islands of White.

98 Hyslop, 'White Labourism'; Money, 'World of European Labour'. 


\title{
8 The dog that didn't bark \\ The Mufulira strike and white \\ mineworkers at Zambian \\ independence
}

\author{
Duncan Money
}

\section{Introduction}

This chapter is, in some ways, a history of why something did not happen, explained through the history of something which did. This is a way of approaching a historical problem inspired by one of the most memorable scenes in Arthur Conan Doyle's series of short stories about the detective Sherlock Holmes, which occurs in 'The Adventure of Silver Blaze'. The scene features the ever-observant Holmes, who is investigating the disappearance of the prize-winning race-horse Silver Blaze, patiently explaining to a Scotland Yard detective, Inspector Gregory, the significance of a dog not barking:

INSPECTOR GREGORY: Is there any other point to which you would wish to draw my attention?

SHERLOCK HOLMES: To the curious incident of the dog in the night-time. GREGORY: The dog did nothing in the night-time.

HOLMES: That was the curious incident. ${ }^{1}$

Holmes inferred that the absence of an expected reaction was significant, in this case the dog's failure to raise the alarm. ${ }^{2}$ The aim of this chapter is to make inferences from the absence of an anticipated reaction, that is, the failure of whites on the Zambian Copperbelt to seriously and actively resist decolonisation. What does this tell us about white society on the Copperbelt? In many ways, the Copperbelt contained all the ingredients for a bloody, protracted struggle against decolonisation: an armed, racist white minority in a highly privileged social and economic position who, in the early 1960s, suddenly found themselves neighbours to newly independent African nations and close witnesses to chaotic decolonisation in Congo. Yet no such struggle occurred. Unlike what transpired in Angola, Mozambique, Zimbabwe and South Africa, the end of white minority rule in Zambia was relatively peaceful. Despite some bluff and bluster, when it came down to it, whites on the Copperbelt grumbled, but ultimately, and rapidly, surrendered political power and accepted life under an African nationalist government. 
Control over the Copperbelt was central to white political control over the region. In the early 1960s, colonial Zambia (or Northern Rhodesia, as it was then called) was part of the Central African Federation, linking the colony with Southern Rhodesia (Zimbabwe) and Nyasaland (Malawi) to entrench white and British control over the region. The British Government had established this Federation in 1953 as a counterpoise to South African influence in the region, and to appease white settler politicians who sought greater autonomy from London. ${ }^{3}$ For settler politicians, the Federation was a way of becoming an independent white Dominion within the Commonwealth, granting them the same status as Australia, Canada, New Zealand and South Africa, a status which the British Government had vaguely promised in the late 1950s. ${ }^{4}$ The Copperbelt was integral to this plan as the economic powerhouse of the Federation and tax revenues from the copper mines effectively bankrolled the project. $^{5}$ Absent this, the Federation would scarcely have been economically viable. There was no other industry of comparable size or importance or, crucially, which employed so many white workers in such a concentrated manner. The mines supported the only substantial white population in the Federation outside Southern Rhodesia's urban centres: some 33,510 people lived in the Copperbelt towns in 1961, almost half of the resident white population in Northern Rhodesia. ${ }^{6}$ Preserving white minority rule was near-impossible unless the Copperbelt's white population leant their active support. ${ }^{7}$

Exploring why they did not tells us something important about the operation and salience of race in different contexts, and about the roots of racial identity. For the first point, it draws our attention to the set of circumstances which make a race a more salient identity upon which people draw, building on Ann Stoler's insight that seeing racism as "built into" the colonial encounter "accords poorly with the fact that the quality and intensity of racism vary enormously in different colonial contexts and at different historical moments in any particular colonial encounter' ${ }^{8}$ For the second point, it raises the question of what did being white on the Copperbelt mean? How and where was racial identity generated?

It is often assumed that there was no substantive difference between how race operated on the Copperbelt and how it did elsewhere in Southern Africa, and in the wider literature the Copperbelt's white mineworkers have been viewed as simply emulating the organisation and attitudes of white mineworkers in South Africa, who were amongst the staunchest supporters of apartheid. ${ }^{9}$ A major contemporary study of white mineworkers by a team of industrial psychologists concluded that 'the transplantation to the Copperbelt of the essentially conservative and self-centred White attitude pattern prevalent elsewhere in Southern Africa, was historically inevitable'. ${ }^{10}$ It has been regarded as axiomatic that whites across Southern Africa not only actively supported white minority rule and the colonial racial order, but were prepared to offer determined violent resistance to African nationalist movements. 'South African and Rhodesian whites refused to forego their privileged lifestyles' and, following Portugal's lead, 'stood firm against racial equality and majority rule', argued Filipe Ribeiro de 
Meneses and Robert McNamara. ${ }^{11}$ Similarly, Matthew Hughes has argued that the British Government's changing colonial policy in the late 1950s, 'encouraged the whites in the Federation to make common cause with fellow white settler communities in Angola and Mozambique, South Africa, and Katanga, in the hope that, by standing together', they could resist African demands for political reforms and external pressure from newly independent African states. ${ }^{12}$

Many contemporary observers expected such resistance. Plans by the British Government to invade the Federation to suppress anticipated unrest by white settlers worried civil servants that British troops would refuse to fight 'the European mineworkers on the Copperbelt' ${ }^{13}$ Statements of intent about resisting decolonisation are not hard to find. In September 1960, for instance, prominent settler politician Rex L'Ange, who had previously worked as an official on the mines, declared to a public meeting in the mining township of Nkana:

Here, on the Copperbelt, we are right in the front line of racial conflict.... I think we should make it very clear that we look upon this part of the world as our home and birthright, which we have no intention of relinquishing. ${ }^{14}$

Intuitively, then, it might be expected that the longest strike in the history of the Copperbelt mines, initiated in February 1963 by white mineworkers on Mufulira Mine, to be closely connected with decolonisation, an attempt to prevent or wreck a smooth transition to independence under an African nationalist government. Yet this was not the case. The dispute was, in fact, triggered by a demand from the mine management that a group of white workers complete a new form providing information on the work they had undertaken during their shift. That this seemingly trivial issue provoked a major dispute is indicative of the consciousness and priorities of the white workforce, and of the kind of racial identity which developed amongst this workforce.

White workers on the Copperbelt certainly were racist and regarded Africans as more or less permanent subordinates in all areas of life. Racist attitudes appear to have been no less common than elsewhere in the region, indeed the converse would have been odd as large numbers of white mineworkers had spent substantial portions of their working lives in South Africa or Southern Rhodesia. Race operated differently on the Copperbelt, however. Whiteness was not about attachment to geography or to the state. White workers' access to jobs, high wages, housing, health care, education and leisure came via the workplace, not from the state. Maintaining their privileged lifestyle depended less on the maintenance of the colonial political order and more on their capacity to extract high wages and generous fringe benefits from the mining companies through collective action and not, unlike elsewhere in Southern Africa, through legislation.

White employees on the mines thought of themselves as workers, with interests distinct and opposed to their white managers. They perceived that threats to their privileges emanated primarily from white managers, rather than African 
workers, and directed their actions accordingly. These privileges, however, included control over African labour and restricting skilled jobs to people of European descent. Whiteness was therefore a core component of their identity. The aim of this chapter is not - in the manner of the alchemist - an attempt to separate out workers' justifiable class-based demands made on their autocratic bosses from illegitimate racist demands. Instead, it argues that these demands were intertwined and were not regarded as separate by those making them at the time, and that this constitutes a form of "white labourism" that did not rest on explicit pronouncements of racial identity. ${ }^{15}$ The men who initiated and led the dispute at Mufulira did so as conscious members of a racially bound class. It is to this dispute, to the actual struggles occurring in white society during decolonisation in Zambia, to which this chapter now turns.

\section{Labour and industrial strife at Mufulira mine}

Production at Mufulira Mine had begun in 1933 and, thirty years later, it had become the world's largest underground copper mine. The Rhodesian Selection Trust, a company domiciled in the Federation but owned by the New York-based American Metal Company, operated the mine and in the early 1960s employed almost 10,000 people there, around 1,500 whites and 8,000 Africans. ${ }^{16}$ The mine had expanded considerably during the 1950 s as the postwar economic boom and strategic stockpiling of copper by the United States boosted copper prices. A refinery was constructed at the mine in 1952 and a massive expansion of the underground workings, the Mufulira West Extension, began in 1956. Around half of the $£, 14$ million cost of the extension was funded by long-term debt, and the remainder by retained profits. ${ }^{17}$ However, copper prices and profits fell sharply while this expansion was underway and had not recovered by the time the Mufulira West Extension opened in 1962. Controlling costs therefore became crucial.

Production costs had increased steadily during the 1950s at all Copperbelt mines and the single largest component of this increase was wages. The total wage bill for African workers increased from f2.11 million in 1950 to £9.32 million in 1960, while total wages for white mineworkers soared from £4.75 million to $\mathcal{E} 16.12$ million over the same period. ${ }^{18}$ There were, of course, substantially more African mineworkers than white mineworkers, but white mineworkers were paid vastly higher wages, higher both than African wages on the Copperbelt and higher than wages paid to white mineworkers elsewhere in the region. ${ }^{19}$ These higher wages were a particular problem for production costs as the Copperbelt's white workforce was also comparatively larger than white mining workforces elsewhere in the region. In 1963, the 7,776 white employees on the Copperbelt mines constituted 17 per cent of the total workforce, whereas the 2,550 whites on Southern Rhodesian mines represented only 6.2 per cent of the total workforce and the 47,352 whites on the Rand and Orange Free State gold mines formed 11 per cent of the total workforce. ${ }^{20}$ Better paid and proportionately more numerous than their counterparts elsewhere in the 
region, the Copperbelt's white mineworkers were in a position of remarkable privilege but, as will be seen, many also felt the position to be a precarious one.

Labour on all the Copperbelt mines was organised by a rigid racial hierarchy, one that in form was very much like the organisation of work on mines in Southern Rhodesia, South Africa and South West Africa. In these territories though, the industrial colour bar that restricted all jobs perceived as skilled and many semi-skilled jobs to white workers was enforced by legislation. In Northern Rhodesia, the colour bar had no basis in law but was enforced on the mines by agreements made between the mining companies and the two white trade unions: the Northern Rhodesia Mine Workers' Union (NRMWU) and the Mine Officials and Salaried Staff Association (MOSSA). This meant that all work regarded as unskilled was performed by African workers, who undertook most of the manual work underground and in the surface plants: drilling ore in the stopes, removing blasted ore, clearing waste rock, loading skips, etc. Some African workers performed semi-skilled jobs such as driving underground locomotives and operating overhead cranes, while a smaller number held higher-status jobs that involved less manual labour including clerks and "boss boys", who supervised African labour underground. All African mineworkers were supervised by a white mineworker, and the former could not be above the latter in the hierarchy of the mine, regardless of the job they performed.

There was also a clear hierarchy within the white workforce, which was divided into a daily-paid section and a monthly-staff section. Administrative and clerical workers, engineers and other professionals, and supervisors of white labour such as shift bosses, mine captains, and foremen were all graded as staff. The small number of white women who worked on the mines as clerks or nurses in the mine hospitals were also in staff positions. Most staff were members of MOSSA. Daily-paid mineworkers were all men and were all union members, as the NRMWU had run a closed shop on the mines since 1942. Their numbers included artisans such as boilermakers, electricians and fitters, and semi-skilled workers such as operators, and they performed almost all skilled work on the mines: blasting ore, repairing machinery, operating pumps, and driving the winding engines that hauled men and ore up the shafts. Most also had responsibility for directly supervising a "gang" of African workers.

This was, in theory, what daily-paid mineworkers were doing at work. In practice, supervising workers dispersed throughout a vast network of underground tunnels and shafts presents a unique challenge and white mineworkers, backed up by a union that bristled against "interference" from management, had a substantial degree of autonomy underground. From the late 1950s, the mining companies sought closer knowledge of and control over what their expensive white workforce was actually doing at work, as a part of controlling costs. At Mufulira, the mine management began implementing scientific management techniques then prevalent in British industry. Two study teams were deployed to examine jobs performed by white workers looking at "process planning, work simplification, works organisation, layout planning, transport, materials handling, administrations and clerical procedures', insofar as they 
affect the way a job was done. These techniques were an attempt to improve productivity and manage costs by linking pay to performance. ${ }^{21}$ In contrast, the NRMWU had always insisted on standardised basic rates of pay for the same jobs across all mines. With some friction, new bonus schemes were steadily expanded across Mufulira's white workforce until late 1962, when timbermen were incorporated into the scheme.

Timbermen were daily-paid underground workers responsible for constructing and maintaining underground structures of timber and concrete. Most of the manual work was done by groups of between two and six African workers who, in the derogatory language of the time, were employed as "timberboys" and the timberman's role largely consisted of using specialised tools and supervising this group. For this, timbermen were paid 80/3 $\mathrm{f} / \mathrm{s} / \mathrm{d}$ per eight-hour shift, plus a two-shilling bonus if they were required to use a cutting torch, and an annual copper bonus, housing allowance, free electricity and water, subsidised health care and leisure facilities. ${ }^{22}$ All other white employees of the mines received the same, or even better, benefits.

High wages and the provision of a 'miniature Welfare State conceived on lines which made the similar arrangements in the United Kingdom seem parsimonious' by the mining companies enabled white mineworkers to comfortably support families. ${ }^{23}$ Contrary to the conventional image of mining towns as a largely male environment, which was certainly true on the Copperbelt in the 1930 s, by the 1960s there was no pronounced gender imbalance amongst the white population. Most white mineworkers were married and had children, and could be confident that education, health care, welfare and leisure would be provided for their families by the mining companies, provided they kept their jobs on the mine and that these jobs continued to provide such benefits.

Timbermen, like other daily-paid mineworkers, were not actually paid each day and the term refers to the fact that they were employed on a daily basis. They could be fired or resign with 24 hours' notice, which entailed not only losing their job but also the extensive fringe benefits. Refusing to follow the instructions of mine managers was a good way to get fired on the spot, unless groups of white workers stuck together. This is what happened when, on 31 December 1962, Mufulira's mine superintendent informed all timbermen that they would now be required to complete a new form providing details on all tasks undertaken during their shift, how long they had taken to do the task, and what materials had been used in order to receive their bonus. This was a time and motion study which would then be linked to a new categorisation system where all daily-paid workers underground would be rated by officials every six months and ranked as above merit, average merit or below merit. Further bonuses and promotions would be based on merit rating. ${ }^{24}$ Timbermen collectively refused point blank to participate in this.

This was unsurprising. Precarious employment encouraged collective action - while one timberman could be fired easily, sacking all of them would disrupt the operations of the mine - but, beyond this, industrial relations at Mufulira, like all the Copperbelt mines, were poor. It had not even been a year 
since the last strike by white mineworkers had shut down the mine. ${ }^{25}$ While the dispute with white timbermen was developing, mine management had to contend with a strike by some 800 African miners at Mufulira West in protest over the attitude of a white shift boss and a series of wildcat strikes by African smelter workers, in defiance of their union leadership. This is not to say the leadership of the African Mineworkers' Union (AMU) were moderates. On the eve of the shutdown at Mufulira, the AMU declared an unrelated dispute with all mines to try and impose a closed shop on the mining industry. ${ }^{26}$

Most disputes by white mineworkers were generated by contestations over authority and skill with mine management; that is the self-belief of many white mineworkers that they were skilled workers who possessed the necessary skills to do the job with minimal intervention from managers. Carter Goodrich's classic study of conflict in British industry following the First World War, The Frontier of Control, is instructive here. ${ }^{27}$ Goodrich used the idea of the frontier to understand the struggle between unrestrained management prerogative and increasingly assertive trade unions on the shop floor. "Control" was understood implicitly - the Miners' Federation of Great Britain, when asked by a mineowner what they meant by control, replied 'we mean just what you mean when you say we must not have control' - and similarly on the Copperbelt "control" was not clearly defined but involved control over the production process, that is, for white mineworkers, control over time, tools, and African labour. Autonomy, for white mineworkers, was closely entwined with their freedom to control and instruct the African workers they supervised as they saw fit. In the hierarchy of the mine, greater autonomy for some meant increased control and surveillance for others.

\section{The end of empire in Northern Rhodesia}

It is difficult to exaggerate the speed of political developments in Northern Rhodesia during the early 1960s. In 1959, very few people, including African nationalists, white settler politicians or the British Government, could plausibly have expected that Northern Rhodesia would become the independent nation of Zambia within five years, headed by a man, Kenneth Kaunda, then in prison, and governed by a party, the United National Independence Party (UNIP), then illegal.Yet by early 1963, the writing was on the wall for colonial rule. African nationalist movements in all three constituent territories of the Central African Federation had resolutely opposed its formation and consistently agitated against it during the 1950s, with little success until the end of the decade. By 1963, however, both Northern Rhodesia and Nyasaland had been granted a substantial degree of internal self-government - Southern Rhodesia had been granted self-government in 1923 - and African nationalist parties had taken power in territorial elections. The British Government's announcement in March 1963 that governments in individual territories could secede from the Federation therefore sounded the death knell for the Federation, if the decision was not reversed or obstructed. 
Unsuccessful efforts by the United Federal Party (UFP) - the white settler party which governed the Federation - to prevent the disintegration of the Federation had focused on the October 1962 territorial elections in Northern Rhodesia. The Malawi Congress Party had already won a convincing victory in the August 1961 territorial elections in Nyasaland and were pressing to secede from Federation, but the territory's miniscule white population and comparative lack of resources meant the UFP were resigned to losing the territory and focus shifted to retaining control of Northern Rhodesia. In any case, for whites, the real impetus behind Federation had been the possibility of amalgamating Northern and Southern Rhodesia. White control over Southern Rhodesia seemed secure; the African nationalist movement there had not yet recovered from the Federation-wide suppression of nationalist parties in February 1959. ${ }^{28}$ In Northern Rhodesia, complex franchise arrangements held out the slim possibility that the UFP could secure victory, despite the fact that African voters had been included on the electoral roll in substantial numbers for the first time. This was not entirely a forlorn hope. Franchise arrangements did deny UNIP, which won the popular vote by a large margin, an outright majority of seats, but UNIP confounded the UFP's plans by forming an uneasy coalition with a smaller nationalist party, the African National Congress (ANC), and ousted the UFP from power.

Any possibility that white settlers would retain political power relied on the UFP securing the support of nearly all white voters in the territory and attracting a sliver of African votes, the latter thought possible as white politicians were convinced that genuine enthusiasm for Federation by Africans was suppressed by nationalist parties. The UFP therefore ran a campaign aimed at stiffening the resolve of white voters to resist African nationalism through a lurid portrayal of what life would be like for whites under a UNIP government. UFP leaflets distributed on the Copperbelt warned that, after years of prosperity, 'a savage fist is pounding at the door, and the question is whether the benefits we now have, and those yet to come, should be exchanged for the petrol bomb!' and claimed that UNIP supported a mass uprising like Mau Mau, which would see whites murdered in their beds. ${ }^{29}$

Interestingly, white mineworkers and the NRMWU had little discernible involvement in the 1962 territorial election, a noteworthy contrast to their South African counterparts who were a key constituency for those rejecting any reforms to apartheid. The UFP's candidates included eight politicians, six businessmen, five farmers, five mine executives or senior officials, two lawyers, a doctor and a teacher, but no mineworkers though the party's candidate in Roan Antelope, Hendrik Liebenberg, had been an NRMWU branch official at Roan Antelope Mine some years earlier. At Mufulira, the UFP candidate, Pieter Wulff, a South African who was chief underground surveyor on the mine, was opposed by Alec Stevens, a carpenter on the same mine who had been NRMWU president in the early 1950s. Stevens, though, fared poorly and secured less than 7 per cent of the vote.

The UFP's campaign was, in one sense, successful. Dire warnings about African nationalism resonated with white voters and across Northern Rhodesia 
almost all whites voted for the UFP.The enfranchisement of some African voters makes it difficult to calculate the precise proportion of white voters who endorsed the UFP, but it appears that around 90 per cent of white voters in the territory did so on a turnout that exceeded 90 per cent. ${ }^{30}$ These figures, however, disguise the fact that many whites did not vote at all. Many were ineligible to vote as they had not been in the country long enough to fulfil the residency requirements or had not registered to vote. A total of 14,163 (overwhelmingly white) voters on the Copperbelt cast their votes, but the Copperbelt towns collectively had a white population of around 34,000 in 1961. Although a sizable proportion of this population would have been children, substantial numbers clearly did not vote.

A regional comparison is instructive here. One obvious contrast is the failure of white politicians in Northern Rhodesia to prevent the inclusion of steadily larger numbers of Africans on the electoral roll. It is striking that the efforts of the UFP, and whites in the colony more generally, to hold onto political power were so lacklustre. In the early 1960s in South Africa, the National Party was tightening its grip on power and ruthlessly suppressed domestic opposition. Its policy of apartheid was a popular one with the white electorate, coloured voters having been successfully removed from the electoral roll in 1956, and its vote had risen considerably since the 1948 elections in which the party first took power. Similarly, in Southern Rhodesia white voters swung behind the far-Right Rhodesian Front in the 1962 general election, setting the territory's trajectory towards the Unilateral Declaration of Independence in 1965. Divergence between Northern and Southern Rhodesia predated the elections in 1962. The Rhodesian Front's predecessor, the Dominion Party, actually won the highest number of votes in Southern Rhodesia's 1958 General Election, though the complex electoral arrangements handed the UFP a majority of seats. ${ }^{31}$ In contrast, the Dominion Party fared poorly in Northern Rhodesia.

A more proximate and spectacular example of how to prevent decolonisation, or at least attempt to, was provided to whites on the Copperbelt by events in 1960 immediately across the border in Katanga. At Belgian Congo's hastily arranged independence, Katangese politicians hostile to the distant, would-be national government conspired with white settlers and elements in the Belgian Government to form their own, separate state. Using the excuse of an army mutiny that occurred immediately after independence, the province seceded from Congo in July 1960. ${ }^{32}$ Several thousand whites fled Katanga after the army mutiny, streaming across the border into Northern Rhodesia and then into Southern Rhodesia. It might be expected that witnessing the sudden arrival of large numbers of whites fleeing a newly independent African state would have hardened attitudes on the Copperbelt. Roy Welensky, prime minister of the Federation, certainly thought so, identifying 'the evacuation of the Belgian refugees from Katanga' as the 'major cause' pushing white voters in Southern Rhodesia towards the Rhodesian Front. ${ }^{33}$ Yet if anything, the fate of Katanga seems to have discouraged attempts to resist decolonisation across the border. 
Separatist Katanga was bolstered by clandestine military support from white minority regimes to the south, including a steady flow of white mercenaries, and it took three years of fighting with forces from the new national Congolese Government and the United Nations to crush the break-away state. The Federal Government identified the Katangese cause as vital to its own survival, and its involvement in Katanga has been seen as a precursor to the white Rhodesian resistance to black majority rule that continued until $1980 .{ }^{34}$ Elements in the South African Government thought the same. As H.K.T. Taswell, the South African high commissioner to the Federation, explained to his superiors in Pretoria, 'the Federal Government takes the view that Tshombe is fighting their battle for them'. Taswell himself was convinced of this view and urged South African military support for Katanga, because 'ifTshombe fails, the drive to the south will be on. The Rhodesias, already in a shaky position, may collapse and we will be the main target'. ${ }^{35}$ However, as United Nations forces closed in on the Katangese capital Elizabethville in January 1963, a few miles across the border the whites at Mufulira Mine had very different ideas about what their interests were, and how best to protect them.

\section{Shutdown at Mufulira}

Outright rejection of management initiatives, with no negotiation or suggestion of compromise, had been a regular feature of industrial relations on the Copperbelt mines for the previous 25 years. This history of white industrial unrest makes the timbermen's decision and subsequent strike unsurprising, but what is surprising is that many participants in the Mufulira strike would not have been around to experience this history. Figures for 1963 are unavailable, but in both December 1961 and in December 1964, 46 per cent of the white workforce had been on the mines for less than three years. ${ }^{36}$ The average length of white employment was only 5.6 years in $1964 .{ }^{37}$ Frequent disputes meant that newcomers were quickly socialised into confrontational industrial relations, but another factor is also significant: the international experience of this workforce. Almost none of the white workforce were from Northern Rhodesia. They had arrived on the Copperbelt with experience of life and work at mining and industrial centres in Britain, South Africa, and elsewhere around the world. This explains the knowledge of, and hostility to, scientific management techniques, even though these were new on the Copperbelt. Explaining why timbermen had refused to complete any forms, NRMWU President Emrys Williams - a winding engine driver originally from South Wales - explained that the men 'were concerned they were effectively conducting a Time and Motion Study on themselves'. ${ }^{38}$ There was close knowledge of events and trends in industry elsewhere.

It was this knowledge that prompted the timbermen's action. During the final week in January 1963, timbermen refused to go underground or, if they did, refused to complete the bonus form at the end of their shift. Mine management immediately moved to discipline them, and on 4 February notice was 
given individually to timbermen that there was no work available for them until they obeyed instructions. Effectively, they were laid off without pay. In response, artisans across the mine refused to complete their bonus forms and on 9 February took wildcat strike action. An artisan's delegation to the mine manager, Noel Kenny from Southern Rhodesia, explained that they were not unhappy with their own bonus scheme but were supporting the timbermen. ${ }^{39}$

White managers, too, maintained a tough, intransigent stance and refused to broker any compromise. In meetings with the union, Kenny vowed 'he would shut down the mine immediately, lay off the workers and run the mine on a care and maintenance basis for an indefinite period' rather than accede to their demands. ${ }^{40}$ Once the strike was underway, Mufulira's Canadian mine superintendent $\mathrm{Al} \mathrm{O}$ 'Connell explained it 'was correct and quite reasonable' to close the mine. 'Management', he insisted, 'must be allowed to manage', and this meant white employees doing as they were instructed. ${ }^{41}$ Kenny was furious at his authority being flouted by artisans and timbermen. On 8 February, he made an unannounced visit to the change house at Prain Shaft and offered one of the new bonus vouchers to Schoeman, a shop steward who had just returned from holiday. Schoeman reached for the form but Kenny snatched it back, telling him 'it's just as well you were prepared to take that voucher from me, otherwise your feet wouldn't have touched the floor you would have been fired so quickly'. ${ }^{42}$

This, unsurprisingly, resulted in a hardening of attitudes and preparation for a strike began. As usual, legal niceties were ignored, and no secret ballot of union members was taken, as required by law; a law which had been passed in 1958 following wildcat strikes by white mineworkers. Throughout the dispute, decisions were put to a vote by a show of hands at mass meetings. Even the initial decision not to sign the bonus forms was taken on a show of hands. Shop stewards preferred conducting business in the open in this manner, as they knew they could usually rely on the macho culture of the mines and the tough, masculine self-image of their members. As one man who worked underground at Mufulira in the early 1960s later claimed, 'the men who mined were as hard as the rock they fought underground' ${ }^{43}$ Maintaining this self-image meant not backing down to white bosses or shying away from industrial disputes. Consequently, with sections of the white workforce either on strike or ignoring instructions from mine officials, the management shut the mine on 22 February. ${ }^{44}$ All 800 daily-paid mineworkers were immediately laid off without pay, and the African workforce was steadily reduced as available work diminished.

The fact that the mine had to be closed is worth exploring. Contemporary observers were convinced that white mineworkers did little, if any, actual work. Once underground, it was thought, they wiled away the hours and earned fantastic wages by the sweat of the brow of the African workers they supervised, who did the real work. Andrew Sardanis, who operated a transport business in Nchanga in the 1950s, expressed the common cynic's view that, as African "boss boys" supervised African workers, young white miners 'had very little to 
do except snooze, eat their sandwiches and listen to music on their radios' ${ }^{45}$ Cyril Dunn, foreign correspondent for the Observer, explained that while 'miners in other parts of the world do a great deal of hard manual work', on the Copperbelt even the 'humblest white worker . . . is a supervisor of blacks, who do all the shovelling'. ${ }^{46}$ In his 1963 book on the Central African Federation, the Guardian journalist Patrick Keatley offers a snapshot of a typical white mineworker, 'Jacobus van der Merwe': 'Let us say that Jacobus is not, unhappily, one of Mother Nature's most gifted creatures, and that because of his limited intelligence ... he has been assigned the simplest sort of job and has never been promoted'. Keatley contrasts "Jacobus" with an imagined African miner, "Moses Chona", 'sweating it out with a drill in humid, choking conditions underground', for substantially less pay. ${ }^{47}$

The forced shutdown of the mines whenever white mineworkers went on strike suggests that they did fulfil an important role in production, as well as in the supervisory hierarchy. The mines could not function without them and white mineworkers had, for over two decades, used this to their full advantage. ${ }^{48}$ This, however, was changing, as the dispute at Mufulira would reveal. Changes in the organisation of work during the 1950s had steadily reduced the proportion of daily-paid mineworkers, even as the overall size of the white workforce had grown. Increasing numbers of whites were employed as officials.

There were still enough daily-paid workers at Mufulira to cause serious problems though. A Board of Enquiry was hastily arranged by the colonial administration to resolve the dispute. This Board, headed by Sir Charles Hartwell, formerly chief secretary to Uganda's colonial government, was mystified about the dispute. White workers who appeared before the Board expressed a deep-seated conviction that the mine management would use any information supplied in the forms against them. ${ }^{49}$ Another objection was made to the Board as well: filling in forms was not their job. NRMWU representatives explained that a mining official could note down the time it took to complete a job, but timbermen could not, as 'a daily-paid Timberman is not in the same category' ${ }^{50}$ It emerged that a version of these forms had previously been filled by shift bosses, an arrangement which timbermen and other white workers were happy with. This points to their self-identification as workers and an understanding that workers were white men who performed manual tasks. Timbermen, as one explained to the Board, would only do the job they were employed to do and 'they were not employed as clerks' ${ }^{51}$

These arguments made little impression on the Board, who recommended an immediate return to work. ${ }^{52}$ In turn, this made little impression on the strikers, who voted at a mass meeting to reject the report entirely. The Board had no way to enforce their recommendation as, while not exactly maintaining a laissez-faire attitude, the colonial administration and Federal Government had comparatively little involvement in industrial relations on the Copperbelt. African trade unions, for instance, were not illegal, and the kind of industrywide machinery for conciliation and collective bargaining brought in by the Industrial Conciliation Acts in South Africa and Southern Rhodesia was never 
established in Northern Rhodesia. Consequently, trade unions were not incorporated into the state, as white trade unions elsewhere in the region had been. White mineworkers' leaders carefully guarded their autonomy and successfully opposed any attempt to implement a version of the Industrial Conciliation Act in Northern Rhodesia.

The strike was largely a trial of strength between the NRMWU and Mufulira Mine. Despite the seemingly low stakes, disputes between the mining companies and their white workforce were often discussed in existential terms. 'Let there be no doubt in anyone's mind', NRMWU branch chairman Mieczysław "Frank" Rzechorzek, informed his members, 'the Company would like nothing better than to see this Union wiped out. This is a naked, calculated move to further this end' ${ }^{53}$ Rzechorzek was a firebrand. A 38-year-old miner, Rzechorzek had been born in Poland but left at the outbreak of the Second World War and made his way to Britain, via Algiers, where he joined the RAF as a pilot while still a teenager. He left Britain for the Copperbelt after being demobilised and arrived at Mufulira in mid-1953. ${ }^{54}$ By the time of the Mufulira dispute, he had spent ten years working underground and had been involved in innumerable disputes, including two Copperbelt-wide strikes.

Rzechorzek and other union officials were not ignorant of the greatly altered political context in the early 1960s. From early on, they had sought to reach out to the African Mineworkers' Union (AMU) as an acknowledgement that the dispute impacted a much larger number of African mineworkers. While white timbermen thought of themselves primarily as manual workers, much of the manual work was performed by African workers, who were directly supervised by white workers and whose bonuses were calculated using the same form under dispute. Information provided by white timbermen determined a component of African workers' wages. At the outset of the dispute, union officials had been at pains to emphasise that they 'wanted to remove any impression of their provoking conflict with the Africans' ${ }^{55}$ The union branch also attempted to use the connection between white and African timber workers to their advantage by declaring 'we have a common cause with the African employee in this matter' and attempting to enlist the support of the AMU at a joint meeting. ${ }^{56}$ AMU officials were non-committal, presumably because the interests and perspectives of their members had not been taken into consideration when white timbermen refused to fill in a form, resulting in hundreds of African workers being laid off. ${ }^{57}$

White-owned businesses on the Copperbelt were more responsive to appeals for support. As a Methodist minister in nearby Chingola described it, the Copperbelt towns were 'abjectly dependent upon the copper companies to which they owe their existence' ${ }^{58}$ Fifty-five per cent of all white employees in Mufulira worked on the mine and many of those who did not work on the mines were dependent on the incomes of those who did. ${ }^{59}$ From mid-March, the union sent appeals for assistance to around 300 businesses and responses came back with offers of free meals, free petrol, specially reduced prices and extended credit for laid-off white mineworkers. With the mine closed, however, other 
economic activity in the town slowly came to a halt. By the end of March, dozens of local businesses - including general stores, garages, car dealers, furnishers, beauty parlours, jewellers, cycle shops, cafes and the Mufulira Chamber of Commerce - had contacted the Ministry of Labour to urge intervention to end the dispute as business was at a standstill. ${ }^{60}$

The weeks-long stalemate gradually turned against white mineworkers. Their power relied on the capacity to inflict a heavy financial penalty on the mine-owners by disrupting production. When mine managers were prepared to wait out the dispute, there was little they could do. The union leadership could not make good on their threat to expand the strike by pulling workers at other mines out on strike, as they had done in previous disputes. Other threats were equally empty. Emrys Williams declared that he was prepared to go to London to give the British Trade Union Congress a first-hand account of how the company had locked out their members and have Copperbelt copper declared "black", so British dockers would not unload it. ${ }^{61}$ Nothing came of this. Amongst the white workforce, belief that they could win against an intransigent management was diminishing. On 11 April, the Mufulira branch voted 232-136 against returning to work. ${ }^{62}$ The mine management, clearly sensing a wavering of resolve, decided to reopen the mine, and approached daily-paid workers individually asking them to return to work.

Rzechorzek singled out anyone who returned as 'deliberately injuring himself, his community and his Union'. ${ }^{63}$ This did not prevent a trickle of his members returning to work. The first went back on 11 April and two weeks later 53 were at work. ${ }^{64}$ NRMWU members began picketing the shafts and workshops and some were spotted taking down the numbers of cars so that those who were working could be identified. Mine management claimed that people returning to work had received threats that their cars and property would be damaged. ${ }^{65}$ Indeed, seven daily-paid men wrote to the minister of Labour, Reuben Kamanga, claiming that intimidation had kept them away from work and requesting emergency legislation to make the closed shop illegal; appealing to an African politician for the state to take action against fellow white workers. ${ }^{66}$ Wavering resolve was evident in other ways. Many white mineworkers simply resigned from the mine and left. By late April, one colonial official estimated that around 156 daily-paid mineworkers had resigned from the mine since the beginning of the dispute, and most had left the Copperbelt. ${ }^{67}$ One timberman, for instance, hopped on a cargo ship to New Zealand. 'We have decided to give New Zealand a year's trial', his wife explained, and if they didn't like it then they would move to South Africa. ${ }^{68}$

The decision to reopen the mine was a turning point. There were 650 white staff at Mufulira by 1963, almost as many as the 800 daily-paid workers, and the staff returned to work when the mine reopened. Copper production was restarted, though at a lower level. The position for white mineworkers was becoming unsustainable. Many freely admitted that they were only on the Copperbelt to make money, and by 1 May they had been out of work for over 12 weeks. ${ }^{69}$ Moreover, by this time, it was obvious that there would be no 
solidarity strikes at other mines. The NRMWU Mufulira branch capitulated on 1 May and timbermen agreed to complete the required forms, in exchange for a slightly higher bonus..$^{70}$ This was a serious defeat in two ways: the NRMWU were forced to concede the principle and had incurred a crippling financial cost. The dispute cost the union almost $\mathcal{K}_{6} 60,000$, mostly strike pay, and strikers collectively lost around $\mathcal{2} 250,000$ in wages. ${ }^{71}$

Although defeated, most union members didn't seem to think there was anything fundamentally wrong with the approach they had taken. A month after the end of the strike Rzechorzek was returned unopposed as chairman for a third term at the annual branch elections. ${ }^{72}$ Moreover, there were further wildcat strikes by white mineworkers across the Copperbelt in November 1963, including at Mufulira, where there was a walkout after a white miner was disciplined for allegedly contravening blasting regulations. This was the seventh wildcat strike by white mineworkers on the Copperbelt mines that month, and again no ballot was taken. Mine management strongly suspected that the reasons for the strike had been "trumped up" because there had already been a strike at every other mine and so "Mufulira were the "odd men out" on the Copperbelt' if they did not organise one. ${ }^{73}$ Mufulira's NRMWU branch had a militant, combative reputation to maintain.

The AMU's patience with white industrial unrest had finally worn through. While at best noncommittal during the Mufulira's timbermen's dispute, the union denounced the wildcat strikes during November. Matthew Mwendapole, an AMU official, accused white strikers of attempting to blackmail the new government, and pointed to the dual nature of their demands. White mineworkers were seeking guarantees from the mining companies 'in respect of pensions and savings, but also in respect to other preferential and discriminatory practices to which they have been accustomed for a long time' ${ }^{74}$ Although striking white workers 'denied categorically' that their aim was blackmailing the government - it was the companies they sought guarantees from - Mwendapole was entirely correct in identifying the intertwined nature of their demands. ${ }^{75}$ Protecting their financial rewards from their employers was, for white mineworkers, not separate from preserving racist working practices. They were a privileged, racially delineated class and wanted to keep things that way.

\section{Conclusion}

The Copperbelt of the early 1960s occupied an intriguing chronological and geographical position. Quite suddenly, and unexpectedly, its white inhabitants found themselves on the northern edge of white-ruled Southern Africa, with the British Empire unravelling around them. It might reasonably be expected that these racist mineworkers would have fought tooth and nail against an African nationalist movement about to upend white minority rule and take power. They did not and, reflecting on the vignette that opened this chapter, the existence of an absence can be significant. That white workers on the Copperbelt did not actively resist decolonisation tells us something about how they 
saw themselves and how they saw their place in the world. It does not suggest that these whites were a quiescent population, generally happy with their lot. There were serious industrial upheavals on the copper mines prior to Zambian independence.

White mineworkers constituted a transient population tied to an extractive industry and had no real abiding interest in Northern Rhodesia, the territory they happened to be in. This was important. Consequently, the fortunes of these white workers were much less tied to the state and to the land than elsewhere in the region. Whites on the Copperbelt were prepared to go no further than marking "UFP" on a ballot paper to defend white minority rule, and many could not even be bothered to take this step. Yet at the same time, white mineworkers were willing to initiate a lengthy struggle over the seemingly inconsequential issue of who should complete a bonus form. The apparent triviality of this issue, especially in contrast with the magnitude of the political events occurring at this time, should not detract from the seriousness with which participants at the time regarded this struggle, both white mineworkers and Mufulira Mine's management. These were the kinds of issues that white mineworkers on the Copperbelt were prepared to fight over.

This lengthy and bitter dispute locates the origin of the privileged position of these workers as the workplace. It was here that their considerable privileges were obtained and defended. The organisation of the labour process on the mines made white workers a racialised labour aristocracy. This position was based both on the skilled work and supervisory functions they performed on the mines and on their collective willingness to engage in bruising encounters with their employers. Demands by white mineworkers for better pay and conditions were de facto racialised because of their position in the mines, even when they did not make explicit racial appeals and even consciously sought to enlist the support of African mineworkers. Resistance to encroachments from management was an important part of this dispute and, in this sense, it had much in common with disputes in British industry over the application of scientific management techniques. Yet part of the autonomy that they sought to retain was control over the African mineworkers, who almost all white daily-paid mineworkers supervised, and maintenance of the racial hierarchy on the mines.

Despite this, timbermen and other white mineworkers had a strong selfimage that they were working-class because they were male manual workers, something that was resistant to the fact that the African workers they supervised performed most of this manual work. The bonuses that white timbermen received were based, in part, on the work performed by African workers they regarded as their subordinates. Generally, white mineworkers had little interest in the Africans they worked alongside, who, of course, experienced much harsher and more arbitrary treatment from mine managers. The opponents were the mining companies and their local managers whose actions threatened their position as a racialised labour aristocracy whose work was crucial to the operation of the mines. 


\section{Notes}

1 Doyle, Complete Sherlock Holmes, 347.

2 In the story, Holmes infers from the lack of barking that the race-horse was taken by someone whom was familiar to the stable dog.

3 Murphy, 'Government by Blackmail', 54.

4 Cohen, Failed Experiment, 5; Kalinga, 'Independence Negotiations', 238.

5 Hazlewood, 'Economics of Federation', 211-212.

6 Kay, Social Geography of Zambia, 35.

7 Secret - and somewhat hare-brained - schemes by the Federal Government to declare independence relied on the mobilisation of all virtually all white adult males into the police and army, see Welensky Papers, Bodleian Library, University of Oxford [hereafter WP], 234/8, Top Secret (for Prime Minister and Minister of Defence only), 31 January 1961.

8 Stoler,'Rethinking Colonial Categories', 137. Emphasis in the original.

9 Perrings, Black Mineworkers in Central Africa, 130; Butler, Copper Empire, 57.

10 Holleman and Biesheuvel, Attitudes of White Mining Employees. Part I, vi.

11 Meneses and McNamara, The White Redoubt, xxiii.

12 Hughes, 'Fighting for White Rule', 596.

13 Murphy, 'An Intricate and Distasteful Subject', 752.

14 WP 635/11, Speech given by Rex L'Ange to UFP meeting in Nkana, 23 September 1960.

15 The concept was first outlined by Jonathan Hyslop in Hyslop, 'The Imperial Working Class'. He subsequently modified the concept, noting that its initial formulation was 'overly stark': Hyslop, 'Reply to Kenefick', 64.

16 Government of Zambia, Final Report of the September 1961 Census of Non-Africans and Employees (Lusaka: Government Printer, 1965), 25.

17 Cunningham, Copper Industry in Zambia, 106.

18 Phimister, 'Workers in Wonderland?' 198, 212.

19 For a comparison between the wages of white mineworkers on the Copperbelt and their counterparts in South Africa see Zambia Consolidated Copper Mines archive, Ndola [hereafter ZCCM] 17.4.4C, The European Wage Structure on the Copperbelt, 26 February 1958.

20 Northern Rhodesia Chamber of Mines, Mining Industry Year Book 1964 (Kitwe: Chamber of Mines, 1965), 31; Chamber of Mines of Rhodesia, Twenty-Sixth Annual Report for the Year 1964 (Salisbury: Chamber of Mines, 1965), 36; Chamber of Mines of South Africa, Eight-First Annual Report 1970 (Johannesburg: Chamber of Mines, 1971), 72.

21 National Archives of Zambia, Lusaka [hereafter NAZ] MLSS1/25/3, Improvement of Efficiency, Mufulira Copper Mines, 2 November 1959.

22 International Institute of Social History, Amsterdam [hereafter IISH], MIF Box 360, Agreement between the NRMWU and Mufulira Copper Mines Ltd, 24 August 1962.

23 Dunn, Central African Witness, 137.

24 NAZ, MLSS1/25/3, Promotional Policy, Mining Department Mufulira Copper Mines, 21 January 1963. This memo was confidential but was leaked to NRMWU members in February.

25 The National Archives, London, CO 1015/2197, Telegram from Acting Governor to Colonial Secretary, 8 February 1962.

26 NAZ, MLSS1/25/3, Report on a Labour Dispute, Department of Labour, 14 January 1963,12 February 1963 and 21 February 1963.

27 Goodrich, Frontier of Control.

28 Groves, ‘Transnational Networks and Regional Solidarity', 167-169.

29 Mulford, Northern Rhodesia General Election, 32.

30 Ibid., 122.

31 Fraenkel, 'Electoral Engineering in Southern Rhodesia', 1173, 1178.

32 Larmer and Kennes, 'Rethinking the Katangese Secession', 748-752. 
33 'Situation in Rhodesia', The Times, 28 January 1965. I am grateful to Sibanengi Ncube for directing my attention to this quotation.

34 Hughes, 'Fighting for White Rule', 615.

35 Scarnecchia, 'The Congo Crisis', 68-69.

36 Figures calculated from Northern Rhodesia Chamber of Mines, Mining Industry Year Book 1961 (Kitwe: Chamber of Mines, 1962), 31; Copper Industry Service Bureau, Copperbelt of Zambia Mining Industry Year Book 1964, (Kitwe: Copper Industry Service Bureau), 51 . These figures slightly overstate the number of newly arrived white mineworkers as mineworkers who moved to a mine operated by a different company were counted as new employees in terms of length of service. There were, however, only two mining companies in Northern Rhodesia.

37 Northern Rhodesia Chamber of Mines, Mining Industry Year Book 1964, 51.

38 NAZ, MLSS1/25/3, Notes on Board of Enquiry into dispute at Mufulira Copper Mine, 25 February 1963.

39 Ibid., Summary: Main points of disagreement.

40 Ibid., Record of meetings between Mufulira Copper Mines Limited and the NRMWU, 14, 16 and 18 February 1963. Care and maintenance means a mine is closed but maintenance work continues so that production could be restarted in future.

41 Ibid., Notes on Board of Enquiry into dispute at Mufulira Copper Mine, 26 February 1963.

42 Ibid., Record note, 6 May 1963.

43 In this, he was referring exclusively to white miners. Smith, Mad Dog Killer, 18.

44 NAZ, MLSS1/25/3, Record from J.G. Doubleday, 22 February 1963.

45 Sardanis, Another Side of the Coin, 25.

46 Dunn, Central African Witness, 137.

47 Quoted in Phimister, 'Workers in Wonderland', 191.

48 This can be usefully contrasted with the wildcat strikes by white miners in South Africa in 1979 when their union 'tried to demonstrate that the white miner was irreplaceable' but the mines remained open and production continued.Visser, 'Miners' Strike of 1979', 203-204.

49 NAZ, MLS1/25/3, Report of Board of Inquiry into the cause of the trade dispute between certain section of European employees and Mufulira Copper Mines Limited over bonus system of payment, 4 March 1963.

50 Ibid., Notes on Board of Enquiry into dispute at Mufulira Copper Mine, 25 February 1963.

51 Ibid., Notes on Board of Enquiry into dispute at Mufulira Copper Mine, 26 February 1963.

52 Ibid., Report of Board of Inquiry into the cause of the trade dispute between certain section of European employees and Mufulira Copper Mines Limited over bonus system of payment, 4 March 1963.

53 Ibid., Mufulira branch newsletter, 11 April 1963.

54 'Mufulira Roundabout', Mufulira Magazine, September 1953.

55 NAZ, MLS1/25/3, Notes on a meeting held at the Ministry of Labour and Mines, 8 February 1963.

56 Ibid., Notice to all Timbermen, NRMWU Mufulira branch, 2 February 1963.

57 Ibid., Record note, 6 May 1963.

58 Morris, The Hour After Midnight, 10.

59 Government of Zambia, September 1961 Census, 22.

60 NAZ, MLS1/25/3, Letter from J.G. Doubleday to Manager, Naik \& Sons, Mufulira, 30 March 1963.

61 ZCCM, 10.5.8D, Telex from Mining Employers' Committee to Anmercosa and Roselite, Salisbury, 4 April 1963.

62 NAZ, MLS1/25/3, Record from J.G. Doubleday, 11 April 1963. There were a large number of abstentions.

63 Ibid., Mufulira branch newsletter, 11 April 1963.

64 Ibid., Record from E.W. Dunlop, 11 April and 24 April 1963. 


\section{Duncan Money}

65 Ibid., Record note, 6 May 1963.

66 Ibid., Message to Minister of Labour and Mines from Seven Reasonable Minded Union Members, 16 April 1963.

67 Ibid., Record from E.W. Dunlop, 27 April 1963.

68 'Teacher Emigrating to New Zealand', Mufulira Mirror, 24 May 1963.

$6943 \%$ of 468 white employees surveyed in 1958 stated that their reasons for coming to the Copperbelt were purely financial. Holleman and Biesheuvel, Attitudes of White Mining Employees. Part II, ii.

70 NAZ, MLS1/25/3, Record from E.W. Dunlop, 1 May 1963.

71 IISH, MIF, Box 319, Report on the NRMWU's Dispute at Mufulira Copper Mine, 15 May 1963.

72 'Local Union Elections', Mufulira Mirror, 7 June 1963.

73 ZCCM, 10.5.8D, Telegram from Chamber of Mines to Roselite and Anmercosa, Lusaka, 29 November 1963.

74 'Rockbreakers Strike at Mufulira', Northern News, 29 November 1963.

75 'Miners Hit Back at African Union's "Blackmail” Claim'. 


\title{
9 Social engineering and scientific management
}

\author{
Some reflections on the apartheid \\ public service and historical process
}

Neil Roos

\section{The apartheid public service: some historiographic frames}

There is a burgeoning literature on apartheid South Africa. Much of it focuses on black experiences, the struggle and the uneasy and ambiguous transitions to post-apartheid society. The Truth and Reconciliation Commission (19952002) spawned a genre of confessional accounts. And more recently, a range of memoirs written by former white male conscripts into the South African Defence Force, apartheid's army, have begun to appear on the bookshelves of the upscale Exclusive Books. By and large, the history of ordinary whites under apartheid is left homogenous and monolithic in all of these traditions, and it is premised often on the incorrect dichotomy between conservative Afrikaansspeakers and more liberal English speakers. ${ }^{1}$ The historiographic failure to tackle issues of white class and race formation, identity and everyday life leaves unasked other political and ethical questions clustered around complicity, participation (including knowledge and denial by perpetrators), coercion, agency and its limits.

The National Party's 1948 election victory came as something of a surprise, even to many of the Party faithful. Almost as soon as it assumed office in 1948, the new government had to contend with rising tides of resistance to racial segregation. Deploying all branches of the state ruthlessly, if never entirely systematically, in response to these challenges, the National Party (NP) government did little during its early years to legislate and implement the political geography of separate development for which it would later become infamous. Elements within the NP and those close to it did, however, show their will to surveil certain classes of whites. This imperative applied equally to women as to men and it demonstrates something of the historical distrust and disdain extended by Afrikaner elites to the white poor; the advent of apartheid in 1948 was at best only half a generation removed from poor whiteism and the economic, cultural and psychological ravages of land evictions, unemployment, social dislocation and malnutrition. These interlocking traumas affected not only the white poor but also the middle-class custodians of Afrikaner nationalism, who feared both a dilution of the Afrikaner volk (people) as well as a blurring of the lines between black and white. Working-class (or potentially 
working, or ought-to-be-working) whites were important for the development of apartheid society. At one level whites, especially Afrikaners, needed to fit the volk-ish imagination of Afrikaner nationalism. At another, more practical level, there was a demand for these whites to provide the labour for the expanding apartheid state machinery and also for racially stratified industrial capitalism. And in the late-1940s there did not seem to be much confidence amongst Afrikaner nationalists in government, state departments or universities that whites generally were up to the task. By the early 1960s these issues were more or less resolved and the government underVerwoerd was able to turn to matters closer to his heart, elaborating and applying the broad strokes of separate development and its legitimating ideologies.

This chapter forms part of a broader study into the history of whites under apartheid which investigates historical processes of accommodation in a racial state. In the bigger project I ask firstly how and why white elites, for the purposes of this study, NP politicians, state bureaucrats and Afrikaner nationalist intellectuals, sought to engineer and manage ordinary whites. Far-reaching, elaborate and sometimes invasive instances of reform and regulation took place across a wide topography of institutions and locations and were given effect by the law, by school curricula, by religious homilies and, as we shall see in this chapter, institutional procedures for regulation and discipline. Secondly, I investigate how these subaltern whites, all some distance from the centre of official power and authority, responded not only to the material opportunities and ideological blandishments of apartheid society, but also to the ways that they were regulated and subject to various schema for improvements and sanction. ${ }^{2}$ Part of my objective is to assess how the histories of these processes help us understand the everyday world of whites, at least those in the lower social classes of apartheid society, and some of the diverse ways in which they were bound into and participated in the maintenance of apartheid society as well as the nature and impact of transgression, defiance and indocility.

The bulk of this chapter concentrates on the development of the public service (staatsdiens), with an emphasis on the role of the Public Service Commission (PSC), which was a permanent Commission whose major responsibility lay in recommending public service appointments and promotions, but which evolved under apartheid into a kind of supra-bureaucracy. Most scholarship on the apartheid bureaucracy comes from the fields of management and public administration. ${ }^{3}$ Those from the critical social sciences are few in number, but significant for the ways that they locate the public service in the framework of the apartheid state, as well as contemporary class and race relations. Probably the most well-known is Dan O'Meara's magisterial history of the 'forty lost years' represented by the NP's occupation of office. ${ }^{4} \mathrm{He}$ included a substantial section on the apartheid state machinery, and at the time, his work marked a notable departure from state/capital analyses of apartheid society. He did however confine his interest to the upper echelons of the civil service, and the power of senior bureaucrats to "run" their ministers and shape the policy-making process. ${ }^{5}$ In another departure from the then-dominant Marxist historiography of 
South Africa, sociologist Ivan Evans used a case study the Department of Native Affairs to situate that bureaucracy at the very centre of the development of apartheid between 1945 and $1960 .{ }^{6}$ And in an essay that bore the imprint of the Wits History Workshop, Deborah Posel sought signs of class-based consciousness and organisation amongst white public servants. Despite dissatisfaction with their conditions of service, she argues, public servants were not able to "resist" due to the weakness of their representative body, the Public Service Association, and its unwillingness to challenge the government. Consequently, these officials were unable to enjoy fully the 'wages of whiteness', since they were stigmatised within broader white society as incompetent and the beneficiaries of party political favouritism. Like Posel, I concentrate on the experience of white public servants, linking these to the operation of race in apartheid society more broadly. ${ }^{7}$ By the late 1950s, the public service employed around 30 per cent of all working whites, making it the largest single employer of whites in the country; and between 1946 and 1969, the number of Afrikaner civil servants increased by a staggering 98.5 per cent. ${ }^{8}$ Without any doubt, racially reserved access to fairly well-paid work represented the major foundation for accommodation and complicity on the part of white civil servants; in the idiom of sociologist Michael Burawoy, these jobs were the methodology by which consent was manufactured, at least between those white beamptes (officials) and the apartheid state. ${ }^{9}$ But by itself, the idea of co-optation and "manufactured consent" is too simplistic a rendering of the sociologies of work- race- and state-making that took place in the staatsdiens. I shall argue that attention to the ideologies, regulations and forms of discipline and convention to which white public servants were subject in the workplace helps us understand with greater nuance some of the terms of their incorporation into both the staatsdiens and apartheid society.

While developments in the public service labour process do shed light on large-scale structural features of accommodation that were inscribed in law, in the transformation of the public service and the regulations which governed it, they do not account for diverse white working-class formulations of race and racial identity. In short, more top-down institutional histories are unable to connect the racism of a society and that of a class, or to acknowledge the working-class agency in race-making. Drawing on material yielded by the official archives as well as from interviews, I shall tease out several of these historically constituted strands that existed within the broader parameters of the state and the NP's unfolding apartheid project.

These fragments, including both racial violence and flickers of humanity shared across the colour line, are significant historically and historiographically. ${ }^{10}$ They reveal how subaltern iterations of race did not always coincide with the kind represented by the apartheid state, and thus challenge the usefulness of generic assumption of "whiteness", even when these are refined to, say, "apartheid whiteness". This observation is by no means intended as any kind of apologia. To the contrary it reminds us that race was made not only from the top, but also from the bottom, and it invites us to theorize and speculate how state and subaltern racism were connected. 


\section{The NP and the public service}

Apartheid-era Afrikaner nationalism cohered around the notion of volksgebondenheid (unity of the people) and the aim of uplifting and securing the future of the volk. In the romantic logic of volksgebondenheid, the major purpose of the state was to serve the volk. ${ }^{11}$ O'Meara goes on the claim that in light of the principles of volksgebondenheid, the Westminster-derived culture of civil service neutrality, and the 'mythology of the state-as-arbiter' had little appeal in the NP.The Party hierarchy understood the state, including the civil service, as an instrument to serve the volk, itself embodied in the volksfront of the NP. ${ }^{12}$

Despite the NP's preference for large government and an interventionist state, a sensitivity nurtured by the resilience and complex legacies of white poverty, the public service establishment initially expanded slowly. In 1948 the number of whites employed in the public service (excluding the military and the police) grew by 6,652 to 105,051 , compared to a growth of 9,566 in $1947 .{ }^{13}$ And initially at least, the advent of a new administration in the Union Buildings was not matched by wholesale changes to the upper ranks of the bureaucracy: during the NP's first year in office, only three new heads of department were appointed. ${ }^{14}$ Nor was there much sign yet of the new ethos for the public service described by O'Meara. The sidelining of Major-General Evered Poole, next in line to become chief of the general staff and the resignation of W. Marshall Clark as general manager of the South African Railways in 1949 generated a myth amongst non-Nationalist whites, especially English-speakers, that the NP purged its political opponents from the public service, but there is little evidence of a systematic eviction of non-Nationalists from the senior ranks of the public service. ${ }^{15}$

Beyond the installation of a new government in 1948, the key to understanding the apartheid-era modernisation and expansion of the civil service is the role of the five-man Public Service Commission (PSC), an institution that predated the NP government. In the immediate aftermath of the political transition in 1948, there emerged some tension between the executive and the PSC on the role of the bureaucracy. While the former envisaged a public service that would support its political ambitions and its hope to entrench Afrikaner nationalism as the dominant ethos for (white) public life in South Africa, the PSC commissioners, all veterans of the service and schooled in the tradition of public service "neutrality", favoured one that was less susceptible to executive influence.

An important battle in the turf war between the executive and the PSC took place in 1950, when the post of secretary to the PSC, described by the PSC as 'one of the most important key positions in the Public Service' became vacant. ${ }^{16}$ The minister of the interior recommended one D.J.C. Steyn, employed then in the Department of Justice, but the Commission, ever wary of executive intervention, rejected his nomination. The new secretary of the PSC, it insisted, needed to command the kind of knowledge and experience that could only be acquired through years of close contact with all departments 
and administrations', implying presumably that Steyn lacked such gravitas. ${ }^{17}$ Eventually, the minister appealed successfully to the governor general. ${ }^{18}$ While it is difficult to demonstrate convincingly that Steyn's "political" appointment brought the PSC manifestly closer to the executive of government, it did chip away at the Westminster-style tenet that hitherto governed the relationship between the executive and its administration. Steyn's appointment arguably helped to position the PSC as an institution with the political will to surveil the new class of white beamptes who were central to the development of the apartheid state but not entirely trusted by its political and bureaucratic masters.

\section{Afrikanerisation and the re-making of the white working class in the public service}

Recruiting for the staatsdiens as a whole fell to the PSC, and was a major priority. Histories of recruitment during the early apartheid years expose some of the ongoing tensions generated between ideological and political pressures from the government, and the PSC's more bureaucratic obligations to manage staff and stretch staffing budgets by accelerating the drive for "efficiency". They also yield some insight into the gradual Afrikanerisation of the service.

Employment for whites in the civil service was characterised by a distinction between policy-making (populated increasingly by members of the Afrikaner Broederbond, a secret society of influential white Afrikaner men) and policyimplementation jobs. The latter were associated with procedural, routine and red-tape tasks. This structure, which was imperial in origin and had been refined in the Indian Civil Service during the early twentieth century, permitted a high degree of centralisation. ${ }^{19}$ In the staatsdiens it was manifest in four basic divisions of work: administrative, or managerial; specialist or technical; clerical (whose staff performed skilled white-collar work with few decision-making responsibilities); and a large general division where workers were assigned to a range of low-level manual, administrative, technical and sometimes supervisory tasks. ${ }^{20}$

Anticipating that the heaviest labour demands would be in the general bands, the PSC initiated "special measures" to solicit applications for these posts in 1948, sending circulars and brochures to all magistrates and school principals. While the PSC persistently distanced itself from cruder forms of interventions, the focus of recruiting drives for general staff did shift to the platteland, which was the heartland of the NP's support. The PSC report for 1948 did find it worth reporting that, of 2,004 applications for entry positions, 73 per cent were from smaller centres and country districts. ${ }^{21}$

Overall however the results were disappointing, especially with respect to male applicants. ${ }^{22}$ In its attempts to increase the pool of recruits into the general bands, the PSC was forced to tamper with age limits for entry into the service. Under the 1923 Public Service Act, male candidates appointed to the general division had to be between the ages of 16 and 25, while females between 18 and 25 were considered; the PSC and the minister of the Interior agreed to 
a suspension of the regulations to allow temporary eligibility to the general division of any white man under 50 years of age. ${ }^{23}$ These regulations were not altered for women, testament to the gendered ways that both the PSC and the minister imagined the civil service.

During the first years of NP administration the PSC also tried to recruit staff into the more prestigious clerical bands. Reflecting numerous European and colonial legacies, the most common route to entry into the clerical grades of the civil service was via the Public Service Competitive Examination. ${ }^{24}$ In $1949,1,864$ men and women passed the exam, but to the consternation of the Commission, 1,495 candidates failed to respond to letters informing them of their appointment. ${ }^{25}$ Responding in much the same way as the Indian Civil Service did when it was faced with a shortage of prospective candidates for the upper divisions of the service, the PSC decided in 1950 to do away altogether with the exam. ${ }^{26}$ Instead, it would concentrate on recruiting a bigger pool of white school leavers for entry into the general division, and from this group, identifying candidates for future promotion into the clerical bands. It contacted 5,000, emphasising the gross salary they would earn on appointment. ${ }^{27}$ This, too, was met little success. More saliently, the PSC's vacillation about where precisely to target its recruiting efforts might also have reflected the change in the public service from one dependent upon a relatively large layer of self-consciously professional civil servants to a larger entity structured, as I will argue, on centralised authority, hierarchical order and ultimately the work of large numbers of relatively junior staff.

Under apartheid the PSC incorporated women into the staatsdiens more comprehensively than before. Thus in early 1950 the PSC overrode the advice of the Public Service Commission of Enquiry and ruled that women could progress to senior clerical or administrative posts, in other words, enter the management bands. ${ }^{28}$ The proviso, which kept patriarchy in the public service intact, was that 'staff controlled by the [female] incumbent should be predominantly women'. ${ }^{29}$

It is however noteworthy that just as the PSC expanded the permanent employment of women and made provision for their training and advancement, it envisaged that this would occur largely within particularly junior ranks of the service. ${ }^{30}$ Revealing the myth amongst the PSC that women represented short-term and expedient help in the staatsdiens, the number of women on the permanent roster remained consistently lower than those deemed "temporary". Nevertheless, the trend towards the permanent employment of women was a cause of concern to the PSC, as by 1958 it insisted that Departments not only report on the number of women on their respective establishments, but also motivate and explain any increases. ${ }^{31}$

Complaints about the paucity and quality of white applicants was a recurring theme in the PSC's annual reports for much of the decade as it noted repeatedly that the number of applications for employment fell far short of requirements. ${ }^{32}$ In its own analysis, the PSC attributed the critical shortfall of applicants to 'competition for the services of a work seeker'. ${ }^{33}$ The conditions 
of competition noticed by the PSC were rooted in a rapid growth of the national economy after the Second World War. After the war, new goldfields were opened up in the Orange Free State, as well as to the east and west of the original Witwatersrand goldfields. Wartime import substitution had provided a spur to manufacturing, and there was substantial expansion in the metals, engineering, textiles and chemical industries. Net National Income was on an upwards trend. ${ }^{34}$ In an economy with a segregated labour force, this growth spread thin the available pool of white recruits.

In a tight labour market for whites, the public service was poorly positioned to attract as new recruits those able to access more lucrative private sector employment. The class and social stratification of South African society and respective histories of proletarianisation amongst Afrikaans- and Englishspeaking whites meant while English-speakers were generally better-positioned to enter the private sector, the bulk of the new white public servants were Afrikaners. These structural and cultural factors, more than the operation of Tammany Hall-type interventions, contributed to the Afrikanerisation of the civil service. The particular ethnographies of recruitment into the public service, overseen by the PSC, confirm Posel's observation that public servants under apartheid developed into a disrespected stratum of white society. And more important for the purposes of this chapter, expansion during the first decade of apartheid brought into the fold of the public service a large number of people, already exposed at the town hall and the pulpit to certain ideologies about progress, the volk, godsdienstigheid (religious observance) and the races. As discussed later, the structured world of the staatsdiens added layers of regulation and methods of discipline to these ideologies, and sometimes modified them.

In the late 1940s and early 1950s the PSC's recruiting measures were based on posters spelling out the salaries and terms of employment in the civil service, as ineffectual as they were unimaginative. The PSC blamed the failure of successive recruiting campaigns on 'a great deal of ignorance about the Pubic Service at universities and schools as well as among members of the general public', yet it persisted with this approach until 1953, ${ }^{35}$ after which it engaged the services of an advertising agency to produce publicity material. ${ }^{36}$ This material is useful in the ways that it offers a tableau of how the PSC imagined the world of work in the civil service.

In 1955 for instance it published a brochure titled Successful Careers in Service of Your Country. ${ }^{37}$ This began by enunciating the civic and personal dimensions of work in the service. It was a golden age to serve South Africa, and the civil service represented a golden opportunity to serve the country and its people. The service presented young people with the prospect of personal development, and 'gaining insight into all realms of die volkslewe' - the life of the volk. In an appeal that was rather off the mark given the ways the public servants were in fact seen by the white public, it declared that the public service was well-suited to those who cared for their community and were 'willing to accept the status of leadership within the community'. ${ }^{38}$ Hard work could bring quick advancement and would constitute 'service of the nation, work that could not 
possibly be uninteresting' - an observation that demonstrated the author's proximity, ideologically and discursively, to Afrikaner nationalism. Touching on the ideal of stability central to emerging middle-class whiteness, it pointed out to potential candidates that their position and future were protected by law, that they could expect regular salary increments and also assistance with insurance and the purchase of a house. This brochure was distributed to all high schools, and elicited an 'encouraging' number of applications. ${ }^{39}$

The expansion of the public service effectively ended poor whiteism and erased at least the material traces of the Great Depression from white society: in a sense, the state was the creator of a large clerical white working class. But this growth stimulated other contradictions in white society at times of growth and of war: a shortage of white labour. The PSC was thus obliged to rely substantially on "temporary units", usually pensioners or married women. In 1958 for instance, the public service engaged 2,109 men along with 2,567 temporary male employees; 942 women were taken on, as against 916 temporary appointments. ${ }^{40}$ Ironically, just as the PSC's recruiting practices and promotions policies sought to consolidate Afrikaner nationalism's gendered hierarchies, the growth of the public service to meet the needs of the apartheid state obliged it to rely increasingly on the labour of white women.

\section{Scientific management and a "Non-Political" public service}

In addition to recruiting, the PSC's most significant work during the first decade of apartheid was to reform the organisational sociology of the public service. These changes brought centralisation, which positioned the public service well as the bureaucratic counterpart to ideologies of Afrikaner nationalism and corporativism. In the early twentieth century American engineer Frederick Taylor's principles of scientific management, with their siren song of efficiency, were implemented in much of the industrial world, including South Africa. ${ }^{41}$ By the 1940s the novelty of scientific management had worn off, but it received a boost following the success of the quality control movement, pioneered in Japanese industry by W. Edwards Deering. South African industrialists like Albert Wessels, founder of the local affiliate of the Toyota Motor Corporation, were immensely impressed by the possibilities of quality control, and no doubt discussed its merits amongst their peers back home. ${ }^{42}$ It was however something of an innovation for the management of bureaucracies that the PSC applied some of the principles of quality control to the reorganisation of the staatsdiens.

Scientific management was introduced to the public service piecemeal, and in rather unconventional ways, beginning not with the usual organogram and description of posts, but with the introduction of new techniques for reporting on individual staff performance and systems for merit assessment. And it targeted white public servants. This approach might have reflected not only the current popularity of quality control but also contrary demands on the PSC:just as its commissioners and technocrats were developing strategies to implement 
scientific management, they were also expected by government to absorb into the public service workforce large numbers of fairly unskilled whites. Working to an organogram, analysing the posts and measuring the work outputs ascribed to it, would surely have exposed these contradictions, whereas the implementation of individual merit assessment and "quality control" allowed officers to be evaluated and some sort of rank order for advancement be established; as the PSC later explained, to 'eliminate the whispering campaigns so prevalent in the Service today', presumably the belief that those close to the NP received preferential treatment. ${ }^{43}$

For much of the twentieth century white South African elites asserted the European genealogies and connections of white South African society, part of an ongoing project to invoke Europe's intellectual legacy and so lay claim to European versions of modernity. ${ }^{44}$ Thus as the PSC announced a new 'standard staff report form' it was proud to report that this was developed after intensive investigations of promotions practice in Europe and North America. ${ }^{45}$ The aim of the new reporting form was to arrive at a "score" of each public servant's performance. Yet just as the new system sought to silence "whispering campaigns", it created a bureaucratic framework for surveillance, for discipline and other versions of favouritism. For behind the illusion of fairness and objectivity it asked probing and intimate questions about the use of intoxicants and narcotics, dress, personal demeanour, personality, physical appearance and "special" qualities. ${ }^{46}$ In addition to these substantial written reports, each staff member had to be interviewed to 'place before the Committee such facts as may have a bearing on their merit assessment'. ${ }^{47}$ In December 1952 it emerged however that the Department of Inland Revenue refused to implement the new system. Noting that Department's refusal to carry out a 'full scale personal inspection' the secretary of the PSC prepared a report insisting that it carry out 'full scale merit assessment' and warning that further defiance would warrant Cabinet censure with serious consequences for the senior officers of the Department. ${ }^{48}$ Merit assessment sought primarily to standardise procedures for management of individuals in the public service. But it went beyond measuring individuals' work, as it also created an objective criterion to monitor and regulate those departments who resisted the tendencies towards centralised control implicit in merit assessment and scientific management. And quite plausibly, it provided a screen behind which other networks of influence, activated by the Broederbond, operated to advance the careers of favoured mid- and senior-level bureaucrats.

In August 1954 a conference of all heads of department, to discuss merit assessment, was held under the chairmanship of Donges, the minister of the interior who had Cabinet oversight for the PSC. ${ }^{49}$ Although the subject was merit assessment, this gathering represented a significant event in the public service's history of centralisation: heads of department had not previously been successfully summoned together, and the PSC's capacity to convene the meeting also signalled its evolving role as a supra-bureaucracy. By that year, "good progress" had been made in extending and implementing properly merit 
assessment, and in its report to the heads of department, the PSC pointed out that the "difficult periods" in the introduction of the system, which it hinted darkly were inspired by party political allegiance to the old United Party government, had ended. ${ }^{50}$

In 1957 it reported that 8,561 officers were assessed, and that the system had been extended to those who did not normally qualify for merit assessment. ${ }^{51}$ Numbers continued to grow: 9,059 in 1958, 8,904 in 1959 and 10,549 in $1960 .{ }^{52}$ The PSC attributed the steady increase in the number of officials who were assessed to the shortening of the qualifying period of service, and this in turn might have represented a drive by the PSC to promote the upwards social mobility of public servants, which coincided with the broader Afrikaner nationalist imperative to advance the interests of the volk. The merit system did however contain at least one contradiction. As we shall see, the staatsdiens was expected to provide employment for whites who would otherwise struggle to find work in the "open" market, even one circumscribed by a colour bar. They, along with other whites in the lower bands, and of course women retained in "temporary" positions were unlikely or unable to qualify for promotion. This lessened the impact of merit assessment as a tool to regulate these officials.

Merit was the first dimension of the PSC's reform of the operation and management of the public service around principles of scientific management, and it gave early momentum to discourses within the service about efficiency. As the PSC later observed, merit allowed it to identify and then discipline, demote or in some cases, dismiss those who performed poorly. ${ }^{53}$ In its early days, heads of department were reluctant to connect the new assessment system to sanctioning officers for inefficiency and the PSC noted that instead of leaving this task to the discretion of departments, it would have to develop the means to prosecute inefficiency under the 1923 Public Service Act. The existing Act, legislated long before the drive to efficiency, was however cumbersome, and by 1953 the PSC had managed to secure an amendment. In that year, it reported that one female officer had been reduced in rank and her salary reduced by £20 per year, while a male officer was dismissed. ${ }^{54}$ It boasted later that those subject to merit assessment showed a marked improvement in the quality of their work, although there may have been an element of self-justification in this claim, given the energy and resources allocated to developing its procedures and application. ${ }^{55}$

Although it was seldom enunciated explicitly, public servants were expected to know a cultural curriculum primarily made up of knowledge about race but also gender, and sometimes, class. As the racial and gendered struts of apartheid society were bulked up, the racial and gendered knowledge required of its servants receded to the background of the archive, evidence of the taken-forgranted presence of these hierarchies in white South African society. At times, however, the official archive does reveal quite clearly the demand for such knowledge. 'What is your knowledge of coloureds', asked a 1951 memorandum setting out the questions for merit assessment. ${ }^{56}$ 
The demand for bigger government as apartheid's imprint on South African society became larger and more complex, along with a government decision to suspend increases in the public service establishment, pushed the PSC to engage more deeply with scientific management. Moving from monitoring of the individual, it began to pay increasing attention to 'methods and systems of work' ${ }^{57}$ In other words, greater efficiency.

By 1954 the PSC had deployed management experts at the State Sawmills in Pretoria and with great delight, it reported that this experiment, on a very small scale, had yielded remarkable efficiencies: production increased by 14 per cent, productivity of "European" and "native" staff by 218 per cent and 201 per cent respectively, and a saving of $\mathcal{E} 54,741$ effected that year. ${ }^{58}$ In what became a model for the training of public service werkstudie (work-study, or efficiency) officers, eighteen were trained at the Pretoria Sawmill site in the methods of analysing and improving workplace efficiency. ${ }^{59}$

After its early successes, the PSC proposed that Organisation and Methods Study (O\&M) sections be established in every state department. ${ }^{60}$ During that year already it designated 100 staff members as O\&M officers. ${ }^{61}$ By the following year it had in place a curriculum of training courses. These courses covered the fundamentals of scientific management like techniques of work measurement, analysis and improvement of organisation, calculation of staff requirements and office mechanisation. ${ }^{62}$ The PSC's enthusiasm for scientific management was unwavering, and by 1961 it had trained 169 O\&M officers, and had decided to send several O\&M inspectors to Canada and the USA to study the latest innovations. ${ }^{63}$

Reflecting the growing international interest in human resource management the PSC in the late 1950s added this feature to its repertoire of management instruments. Its particular interest was in 'occupational adjustment problems', and between 1959 and 1961, vocational psychologists investigated 442 public servants. The reporting categories used by the PSC were vague: persons misplaced (158); persons who needed psychological therapy and occupational guidance (179); and persons with other problems (105). ${ }^{64}$ Given however the extent to which merit assessment roamed into the reaches of the personal, the overarching ideological framework of the bureaucracy and the extent to which the PSC sought to standardise work and eliminate dissidence, it is not implausible to presume that in addition to more conventional cases of people being in the wrong jobs, or suffering more universal psychological disorders, there were included in this number officials who were "misplaced" or "problematic" in terms of the cultural strictures of apartheid society. In a novel study, Will Jackson draws on some of Frantz Fanon's key claims to demonstrate how conditions of colonialism created certain psychopathologies amongst whites in colonial Kenya. ${ }^{65}$ Quite possibly, similar dynamics were at play within the occupational adjustment scheme. Moreover, it became another tool for discipline, regulation and the production of sameness amongst civil servants.

The drive for efficiency in the staatsdiens was not without its contradictions, and it often clashed with the apartheid policy of "civilized labour" for whites, 
and the Afrikaner national ideal of providing livelihoods for otherwise unemployable whites. Referring to staff outside the administrative sections, in 1951 Minister of Labour Ben Schoeman announced that

we should not create a permanent stratum of unskilled European labour. We should ... take out those unskilled Europeans who are adaptable, who have the necessary aptitude ... [and] give them training. That is how we will get the movement from the unskilled, right up to the skilled. ${ }^{66}$

Effectively his declaration re-located the colour bar to a higher level, and nowhere were the principles of civilised labour applied with greater vigour than in the staatsdiens. Between 1948 and 1959 for instance, whites working in the railways were steadily re-assigned from labouring to supervisory positions during that decade the number of white "railworkers" (labourers) fell from 17,407 or 17.7 per cent of the total number of white employees to 12,131 or 10.7 per cent. ${ }^{67}$ The tasks which the men performed hardly changed, yet their wages were significantly improved. Native Representative in the House of Assembly Margaret Ballinger tartly noted that "non-Europeans" were being engaged from $2 \mathrm{~s} 6 \mathrm{~d}$ to $3 \mathrm{~s} 6 \mathrm{~d}$ a day, while "Europeans", doing the same work, were paid at supervisors' rates and taken on from $8 \mathrm{~s} 6 \mathrm{~d}$ to $14 \mathrm{~s} 6 \mathrm{~d}$ per day. 'This is going to mean a very considerable increase in the burden of the Public Service', she concluded. ${ }^{68}$

Since at least the advent of Union in 1910, whites had found the state a source of sheltered employment. After the NP took office, however, it tried to expand protected employment to cater specifically for disabled and poorly educated whites, with the Ministry of Health and Welfare its greatest champion. Numerically these whites were not a significant source of electoral support for the NP, but culturally, they struck a chord with Afrikaner elites who held a deep dread of whites being reduced to pecuniary, beggary and the socioeconomic status of South Africa's subject races. Plans to provide sheltered work took two forms. Firstly, the Ministry proposed the idea of establishing factories and workshops to employ physically and mentally handicapped whites, especially the blind and 'the type who won't find work easily', and to this end in August 1949 the minister convened a Commission of Enquiry into Protected Work. The PSC's submission to the Committee revealed differences between it and the government on the role of the state in supporting these whites. Presenting as a case study two state-run factories for the disabled, one at Pietersburg and the other at Potchefstroom, the PSC showed that while the Potchefstroom factory cost the fiscus in 1948/9 $£ 9,546$, the provision of pensions for the entire complement in sheltered work at the factory would cost only $\mathcal{E}^{4,000}$ per year. Faced with these wretched statistics, the Commission recommended that it was neither sensible nor economic to implement a system of workshops and factories for the white disabled, and if the government wished to pursue the idea, it should do so in collaboration with private business. ${ }^{69}$ The PSC won this round, as the minister quietly dropped his proposal. 
Secondly the minister prevailed upon his colleagues in other departments to employ another category of whites that 'wouldn't find work easily'. These men and women were not physically disabled but were described in the brutish language which Afrikanerdom's elite sometimes used towards its subalterns as halfgeskooldes - half-educated people. His directive was interpreted by senior departmental functionaries to also incorporate 'idlers, hoboes and similar types', or as they were described in some official directives as blanke tsotsis, a racially loaded term implying that they were not-quite-white thugs. ${ }^{70}$ Those who were employed were incorporated into the public service, and in the sanitised "bureaucratese" of PSC reports, their jobs were listed as 'non-prescribed posts', in other words, jobs that lacked formal job description. This was an anomaly in an increasingly regulated public service, and in 1949 they numbered 1,122, in $1952,1,748,1955,1,510$ and by $1961,1,361 .{ }^{71}$ These workers were used as bag-carriers in the post office, porters in hospitals and railway stations, and as sub-wardens in work colonies and psychiatric facilities. In the work colonies it was halfgeskooldes who marshalled the grinding routines that constituted "rehabilitation" and they were also responsible for punishing detainees. In short, the halfgeskoolde public servants, although few in number, stood at some of the apartheid state's punitive edges, a site where the state was "made real" for South Africans, both black and white.

Scientific management in the public service is important for our argument. It changed substantially the structure of work in the staatsdiens, and it created a framework for the introduction of new and expansive disciplinary interventions. Effectively these measures provided some of the structural conditions to mark out the fields of agency available to public servants in their workplace. Through its efforts to standardise work procedures, the PSC organised the labour process in ways that were not crassly nor explicitly "political", but which brought to it centralisation and an emphasis on hierarchy that served well the interests of a corporativist-type state. And the PSC's reforms made efficiency the language of the staatsdiens. The archival record gives few examples of reference by public servants to, or commentary on, apartheid's projects, grand or little, but it is replete with anxious references to "efficiency". This suggests that public servants - with the obvious exception of those more senior officials responsible for policy-making - were not compelled to enter the difficult political, ideological and moral terrain of apartheid, but needed instead to make regular and consistent choices about "efficiency". In addition, behind their rational and scientific guise, the standards for merit assessment included criteria associated intimately with the type of knowledge required for governance in a racial state.

If the organisation of the labour process, the mechanisms for monitoring and correction offered by scientific management and seldom-specified cultural imperatives were measures designed to manage the dispositions and everyday world of public servants, so too was induction. In 1956 the PSC reported that it was ready to implement an induction training programme that aimed to 'orientate the young public servant for his career and broaden his public service 
background'.$^{72} \mathrm{~A}$ year later it reported that it had laid on 14 part-time induction courses, each lasting three weeks. It gave details of the courses:

i The constitution, organisation and functions of the State;

ii How the State operates;

iii The place and role of the public servant in the scheme of the State's activities;

iv The public servant and his conditions of service;

$\mathrm{v}$ The public servant and his work;

vi The public servant and the citizens of South Africa. ${ }^{73}$

In addition to its explanation of the detail of public service work, the emphasis that induction training placed on the state, and the public servants' duty to the state and "his" role in connecting citizens (white ones) to the state tied in neatly with the concerns of Afrikaner nationalism. By the following year the PSC could report that clerical assistants on probation, as well as the majority of clerical assistants appointed over the previous two years had undergone induction training. ${ }^{74}$ Clearly younger and more junior entrants were targeted for training. The way that the public service induction training was conceived and implemented as well its timing is significant. It suggests that in the face of rising consumerism, as well as growing instances of youth rebellion, manifest most alarmingly amongst white youth in South African by the increasing visibility of "Ducktails", the PSC management was showing signs of anxiety that young white public servants' steadfastness, their sense of purpose and their commitment to the volk needed reinforcement. Through the rest of the decade, and up to the late 1980s - maybe beyond - this anxiety simmered across elite echelons of white society.

During the early apartheid years, the white staff establishment of the public service became increasingly Afrikanerised. The innovations and structural reform of the staatsdiens initiated by the PSC made it centralised, installed sophisticated management tools to advance, or retard, individuals' progress, and discouraged public servants from seeing beyond the range of their immediate jobs, or in the case of more senior officials, those of their subordinates. The public service during the first decade of NP rule developed as a formidable "steel frame", not only for the administration of apartheid society but also for the management of beamptes. ${ }^{75}$

\section{Beamptes' agency and everyday race-making}

As far as its ambitions went, and in the self-assessment of its senior officials, the apartheid state was sturdy, coherent and rational, with an efficient administrative machinery. A turn to the social history of beamptes lower down the public service hierarchy does however indicate tremors and limits in the state's capacity to manage whites. For instance, these excursions reveal beamptes iteratively developing their own understanding not only of racial hierarchies but of social 
ones within the body politic of white society. They show officials acting "compassionately" in a system otherwise premised on the impersonal and immutable banalities of bureaucratic regulations rather than any measure of empathy or humane-ness. They demonstrate unexpected instances of history across the colour line. And they expose an underbelly of popular racist violence that even the apartheid state, itself built on many layers of violence, would repudiate.

Thus, we are witness to an escalating disagreement between two bureaucrats, both white men, which had one of the antagonists issuing something of a monologue on race relations, social class, and the kind of etiquette necessary to mediate interactions between people of different race and social origins. It started with a water dispute between the state entomologist and the medical superintendent of Tower Hospital in Fort Beaufort and boiled over into an angry complaint of how a Mr Yorke, head male nurse at the hospital, addressed the entomologist. In the hospital dining room Yorke 'hectored and brow-beat' the entomologist, in front of junior staff. This 'high-handed action and attitude' to a superior was unacceptable, wrote the entomologist; moreover, Yorke's demeanour and tone were more suitable for 'addressing a non-European labourer'. The entomologist's outrage seemed most piqued at Yorke's disregard for the multiple hierarchies of apartheid society (although he was silent on gender), and it suggests that he had a clear vision of the social order that was beginning to coalesce under apartheid. His understanding was cast in a grain markedly finer than the broad racial categories that had currency amongst apartheid elites in the early 1950s.

Then, the strange case of the "Mauritians". This is a case of greater historiographic significance than political, for it challenges the idea of a state as all-powerful, and it also offers an instance where officials were able to resist and overturn not just the letter of the law but its very intent. One of the foundations of apartheid legislation was the 1950 Population Registration Act which obliged each inhabitant of South Africa to register according to racial characteristics as white, African, coloured or Asian. For state officials the logics of bureaucratic work meant that they could not tamper with these racial categories. There is however evidence that at least some of them acted with what amounted to compassion. In Durban they did so by making use of the sub-category "Mauritian". "Mauritian" was a designation devoid of any particular or unique racial characteristics: no one knew what a "Mauritian" should look like, at least according to the grammar of apartheid bureaucracy, except that "Mauritians" were a sub-category of the white racial group, and there were examples where officials subverted the Act by reclassifying families, usually coloureds or Asians, as "Mauritian". This measure enabled them to become white and so claim access to better wages, education, health care and subsidised housing. Examples like this are few and far between, and they hardly tell against the relentless inhumanity of apartheid. But they do offer a counter against the totalising assumption of the staatsdiens as a wholly effective cypher for apartheid ideologies, an institution that completely stripped from its officials any possibility of agency, defiance or human solidarity. 
Apartheid society was premised not only on white privilege, but also on violence. It was important for the sort of "order" imagined under apartheid that violence was bureaucratic and regulated, sometimes juridical, and always the prerogative of the state. Lynch-type violence, exercised by individuals, was not tolerated. In 1957 one G.O. Opperman, a clerk in the Department of Labour was riding his bicycle inside the corridor of an office, 'when his progress was impeded by [a] native who was walking through the doorway at the time'. It appears that this annoyed Opperman, who 'there-upon assaulted the native'. The archive yielded no pronouncements or regulations on violence although it does show swift punishment for those white public servants who presumed for themselves. Opperman found himself discharged from the public service and charged by the police. ${ }^{76}$ Of the assaulted African, nothing, after his brief and painful vignette as the object of Opperman's unacceptable assault. That this episode attracted such detailed correspondence suggests that violence of the sort demonstrated by Opperman was probably quite uncommon, a tremor that unsettled the style of race and social relations, the form of white supremacy, that underlay apartheid.

\section{Work in the public service and belonging in the apartheid state}

The history of the staatsdiens during the formative years of apartheid supports arguments made by Posel that apartheid state-making was not 'an essentially cumulative process' that developed according to some grand ideological blueprint, but was rather the product of struggles within and beyond the state. ${ }^{77}$ Much the same argument applies for race-making and the idea of what it meant to be white. Given the long history of elite Afrikaner anxiety about the cultural and political reliability of working-class and poor whites, it is hardly surprising that the new government invested so much attention surveilling, policing and where necessary reforming whites in the lower strata of society, including those who occupied "policy implementation" posts in the staatsdiens. As we have seen, these intentions were the subject of contestation from lowerlevel beamptes. It is an irony that the very whites who caused Afrikaner politicians, bureaucrats and intellectuals such distress, and were the subjects of official attention, were sometimes relatively unaffected by the battery of public service regulations because possibilities for upwards mobility offered by the merit system were simply beyond them.

While Posel points out that public servants were not able to enjoy in full the "wages of whiteness", racially privileged work, and a public service that expanded its corps of white employees was the most important means by which the consent of white public servants for the apartheid state was reaffirmed. This consent however was for a general principle of racial supremacy and job reservation for white workers, notably those in the public service, and it left open questions about the particular form of the state or the specifics of white citizenship. This imprecision represented the realpolitik of building an 
electoral base, but it also enabled the articulation of a variety of ideas about what it meant to be white: these differences gave the grounds for many of the instances of "defiance" by whites.

The public service underwent major reform during the early years of NP rule, and in trying to elucidate the terms of this accommodation, I have concentrated on how these reforms contributed to managing the beamptes. I have also argued that to understand the ethnography of work in the public service, we must appreciate the role of the PSC in managing its expansion and reorganisation, and how, incrementally, the apartheid-era staatsdiens broke with earlier traditions of the service.

Although the PSC resisted clumsy political interference in appointments, it did oversee recruiting practices that shifted the public service closer to the demographic and ideological heartland of Afrikaner nationalism. The progressive introduction of scientific management standardised work across departments and reduced the possibility of departments or individuals acting in renegade ways. It provided systems to monitor public servants and measure them on aspects of their work that related to both the technical requirements of the job as well as the new elite's frames of ideological and cultural reference. These matrices furthermore provided the basis for advancement, for the identification of those with 'occupational adjustment problems' and also for punitive action. Collectively, the role of the public service labour process in managing whites suggests that just as the development of the apartheid state was a haphazard and contradictory process, there was in fact evidence of the kernel of a project to re-imagine society in ways beyond the pragmatics of white supremacy. While the full horrors of apartheid state planning and its efforts to manage populations through social engineering would be visited upon blacks from the 1960 s, this kind of state-making vision was manifest earlier in endeavours to manage whites, at least those employed by the state and thus at easy reach.

The expansion of the public service was responsible for the emergence of a new, increasingly Afrikanerised, class of whites employed in clerical jobs. And given the size of the staatsdiens, it was the major institution whereby whites participated in the production of apartheid society, without having to act in specifically racist ways, or demonstrate any explicitly political partisanship. This condition prevailed for much of the apartheid period and arguably, it enabled many whites to assert, after the fact, that they "did not support apartheid". Such claims, however, are built on bad faith as they consciously ignore the privilege and racial supremacy that lay at the heart of apartheid society, and they demonstrate the self-deception and lack of thinking invoked by Hannah Arendt to describe everyday morality in authoritarian societies elsewhere. ${ }^{78}$

As we have seen, white public servants demonstrated significant agency in the ways in which they staked their place in apartheid society, and the kind of identities, behaviour and racial rules they assumed. Even in the workplace, the planes and affective currents of the archive suggests that they were indocile, and as the case studies suggest, they were occasionally defiant. The beamptes' assertion of some autonomy and their transgression is significant - and it isn't. It 
should not for a moment descend to the kind of cynical revisionism that seeks to put a human face on apartheid's beneficiaries or moves these whites into a column headed "opposition", and at every turn these beamptes' history reminds us how they too participated in race-making, that race was made not only from the top, by the state, but also from the bottom. It does however challenge some of the moral and historiographic certainties about apartheid history: about the coherence of the apartheid project, about the stability of racial categories and about the existence of riposte and challenge from within white society, and its limits. And the shards of humanity which they sometimes showed should serve as a pedagogy against essentialised whiteness, a tool in unmaking the history of whites as one exclusively of racial domination, self-interest and deception, accommodation and complicity. Yet the examples represented in these case studies also reminds us that just as these public servants occasionally acted compassionately or crossed the colour line, they did not repudiate apartheid. The Durban officials used the very language and categories of apartheid to help a few families "cross". Testament, perhaps, to the observation that while there were many currents of racial supremacy in apartheid South Africa, and that some of these jarred against each other, few whites were either immune or hostile to racist ideologies.

\section{Notes}

1 I follow Medick, who invokes 'ordinariness' as distinguished from 'high' politics. See Medick, 'Missionaries in the Row Boat?'. I use the term in reference to those described in some historiographic traditions as a working class, whites who broke their way into the 'middle class', and those separated from the mainstream of ordentlike (respectable) white society. It includes both Afrikaans- and English-speaking whites.

2 Following the earlier, more historical tendencies within Subaltern Studies, I use the term 'subaltern' to refer to conditions of domination and subordination within the power structures of a class-divided society.

3 See for instance Grimbeek, 'Vereniging van Staatsamptenare van Suid-Afrika';Visser, 'Die Vereniging van Staatsbeamptes'; Adonis, 'The Public Service Association's Response'.

4 O'Meara, Forty Lost Years.

5 Posel, 'Whiteness and Power in the South African Civil Service', 100. A note on terminology and scope:The staastsdiens incorporated the civil service, referring to individuals in departments directly involved with the daily exercise of administration and governing, while the public service itself was broader and included teachers, scientists, nurses, mechanics, road- and railway-workers, and all those who were employed by the government and rendered a service to the public. Parts of this essay concentrate on those in the administrative divisions and other parts of it take case studies from work in the public service more generally.

6 Evans, Bureaucracy and Race.

7 Posel, 'Whiteness and Power in the South African Civil Service', 99-119.

8 O'Meara, Forty Lost Years, 61-62; Archive for Contemporary Affairs, University of the Free State, Bloemfontein (hereafter ARCA), PV 71: C.D. Taylor collection, 1/11/4/9/1/10/1, Notes on Public Service.

9 Burawoy, Manufacturing Consent.

10 See Painter Southern History Across the Color Line, 2.

11 O’Meara, Forty Lost Years, 41. 
12 Ibid., 61-62.

13 Posel, 'Whiteness and Power in the South African Civil Service', 102; Public Service Commission, Thirty-Seventh Annual Report of the Public Service Commission (Pretoria: Government Printer, 1948), paragraph 69.

14 Public Service Commission, Thirty-Seventh Annual Report of the Public Service Commission, paragraph 46.

15 Giliomee, The Afrikaners, 493. The archival record seems to support Giliomee's assertion.

16 Public Service Commission, Thirty-Ninth Annual Report of the Public Service Commission, paragraph 43.

17 Ibid., paragraph 44.

18 Ibid., paragraphs 44-45.

19 Potter, 'The Last of the Indian Civil Service', 26.

20 With the exception of teachers and nurses, black workers were all confined to the general division where they earned considerably less than whites.

21 Public Service Commission, Thirty-Seventh Annual Report of the Public Service Commission, paragraph 88.

22 Public Service Commission, Thirty-Ninth Annual Report of the Public Service Commission, paragraph 203.

23 Public Service Commission, Thirty-Eighth Annual Report of the Public Service Commission (Pretoria: Government Printer, 1949), paragraph 17.

24 Ibid., paragraph 61.

25 Public Service Commission, Thirty-Ninth Annual Report of the Public Service Commission, paragraphs 190-191.

26 Ewing, 'Administering India', 45.

27 Public Service Commission, Fortieth Annual Report of the Public Service Commission (Pretoria: Government Printer, 1951), paragraphs 137-138.

28 Public Service Commission, Thirty-Ninth Annual Report of the Public Service Commission, paragraphs 143-144.

29 Ibid., paragraph 92. This, incidentally, was a similar condition to one specified in 1961 for 'Bantu Officers', who were expected to take on 'leading roles in the administration of their own communities'. Public Service Commission, Forty-Ninth Annual Report of the Public Service Commission, (Pretoria: Government Printer, 1960), paragraph 23.

30 National Archives of South Africa, Pretoria, (hereafter NA), GG 2148 71/294, vol.1, 'Opleiding van Tiksters', Staatsdienskommissie, 10 Januarie 1956; 71/294B vol. 1, 'Tiksters vir permanente aanstelling', Staatsdienskommissie, 16 Oktober 1956.

31 NASA, PSC 19/22/F/1, GG 2148, vol. 3, 'Statistics required for annual report', 12 December 1958.

32 See for instance Public Service Commission, Forty-Second Annual Report of the Public Service Commission (Pretoria: Government Printer, 1953), paragraph 55. Public Service Commission, Forty-Third Annual Report of the Public Service Commission, paragraph 52.

33 Public Service Commission, Thirty-Ninth Annual Report of the Public Service Commission, paragraphs 297-298.

34 Houghton, 'Economic Development, 1865-1958', 36-48.

35 Public Service Commission, Forty-Fourth Annual Report of the Public Service Commission (Pretoria: Government Printer, 1955), paragraph 26.

36 Ibid., paragraph 63.

37 Ibid., paragraph 64.

38 Posel, 'Whiteness and Power in the South African Civil Service'.

39 Public Service Commission, Forty-Fifth Annual Report of the Public Service Commission (Pretoria: Government Printer, 1956), paragraph 28.

40 Public Service Commission, Forty-Seventh Annual Report of the Public Service Commission (Pretoria: Government Printer, 1958), paragraph 50. 
41 Lewis, Industrialization and Trade Union Organization in South Africa; Webster, Cast in a Racial Mould.

42 Wessels, Farmboy and Industrialist, 154-155.

43 NASA, GG 2148 71/294 vol. 1-1951, Duty Sheets and Procedure Manuals, Forms Z 190 and $\mathrm{Z} 191$.

44 They set out, in a sense, to 'provincialize' and later, to 're-make' Europe. For an elaboration of the cultural arguments and ripostes at play, see Chakrabarty, Provincializing Europe, especially $1-23$.

45 Public Service Commission, Thirty-Ninth Annual Report of the Public Service Commission, paragraph 248.

46 NASA, GG 2148 71/294 vol. 1, Omsendminuut SDK 2/G. Merietebepaling, 13 Januarie 1956. Sekretaris: Staatsdienskommissie.

47 NASA, SDK 2/G/3 vol. 6, L.E.L. Kleuver, Secretary, PSC-The Commissioner for Inland Revenue, 30 December 1952.

48 NASA, SDK 2/g/3 vol.6, Inland Revenue Merit Assessment 1952.

49 Public Service Commission, Forty-Third Annual Report of the Public Service Commission, paragraph 48.

50 Ibid., paragraphs $73-74$.

51 Public Service Commission, Forty-Sixth Annual Report of the Public Service Commission (Pretoria: Government Printer, 1957), paragraph 90.

52 Public Service Commission, Forty-Ninth Annual Report of the Public Service Commission, paragraph 104.

53 Ibid., paragraph 107.

54 Public Service Commission, Forty-Second Annual Report of the Public Service Commission, paragraph 75 .

55 Public Service Commission, Forty-Fourth Annual Report of the Public Service Commission, paragraph 89.

56 NASA, CEN 68 E1/1/1, 13 November 1951.

57 Public Service Commission, Thirty-Eighth Annual Report of the Public Service Commission, paragraph 204.

58 Public Service Commission, Forty-Third Annual Report of the Public Service Commission, paragraph 17.

59 Ibid.

60 Public Service Commission, Forty-Seventh of the Public Service Commission, paragraph 26.

61 Ibid.

62 Public Service Commission, Forty-Eighth Annual Report of the Public Service Commission (Pretoria: Government Printer, 1959), paragraph 70.

63 Public Service Commission, Fiftieth Annual Report of the Public Service Commission (Pretoria: Government Printer, 1961), paragraph 31.

64 Ibid., paragraph 102.

65 Jackson, Madness and Marginality.

66 Davies, Capital, State and White Labour, 341.

67 Ibid., 340-348.

68 Hansard, volume 70, 71, 72 and 73, 1951, col. 5353.

69 ARCA, PV 94: E.G. Jansen collection, 1/47/26/1, Verslag van die Komitee van Ondersoek na Beskutte Arbeid, Sekretaris van Volkswelsyn.

70 See for instance NASA, VWN 119SW 486 vol. 2, Sekretaris van Volkwelsyn - Die Superintendent, Werkkorps vir Blankes, 13 Maart 1951. See also NASA, TES 4915 F28/428 vol. 1, Direkteur van Gevangenisse - Die Sekretaris van die Tesourie, 22 Julie 1953.

71 NASA,VWN 1850. SWA 274, Conference of work colony superintendents, 1957. Work colonies were semi-penal institutions designed to reform and rehabilitate white men who were not-quite-criminal yet deemed miscreant by state-appointed social workers. See Roos, 'Work Colonies for White Men'. 
72 Public Service Commission, Forty-Fifth Annual Report of the Public Service Commission, paragraph 28.

73 Public Service Commission, Forty-Sixth Annual Report of the Public Service Commission, paragraph 81.

74 Public Service Commission, Forty-Seventh Annual Report of the Public Service Commission, paragraph 52.

75 The idea of 'the steel frame' was made famous by former British Prime Minister David Lloyd George who in 1935 described the Indian Civil Service as 'the steel frame on which the whole structure of our government and administration in India rests'.

76 NASA, ARB, 907 1000/21/1/1/10 vol. 6, 25 January 1957-27 May 1957.

77 Posel, The Making of Apartheid, 3.

78 See for instance Arendt, Eichmann in Jerusalem, 112. 


\title{
10 White workers and the unravelling of racial citizenship in late apartheid South Africa
}

\author{
Danelle van Zyl-Hermann
}

\section{Introduction}

Historians of South Africa recognise the 1970s as an important turning point for apartheid. The growth and stability which had characterised the post-war economy was replaced by stagnation and inflation which would last until the regime's demise in 1994. Rising living costs and growing unemployment hit the disenfranchised African population hardest, fermenting enduring discontents about the race-based exploitation and subjugation suffered under white rule. In January 1973, strikes erupted in the factories around Durban as African workers demanded wage increases and industrial representation. Within weeks, strike action had spread across South Africa's industrial centres and by March, 160 work stoppages involving 60,000 workers had taken place. The strikes were typically of short duration as employers scrambled to respond to wage demands and instituted factory-based negotiations structures. Workers returned to the factories - but the collective power and new confidence of the semi-skilled African labour force operating the country's most important industry had been forcefully demonstrated. When from June 1976 violent clashes between schoolchildren and police in Soweto sparked revolt throughout South Africa's black townships, the possibility of African workers throwing their weight behind community-based demands for rights and political freedom threatened political and economic instability the country could ill afford. ${ }^{1}$

These developments provoked a crucial shift in the white regime's rhetoric and strategies of dominance. Even as the government set out to sharpen its repressive tactics - pumping money into defence and counterinsurgency, flooding black townships with military vehicles and young white conscripts, and expanding the powers of the security apparatus - the realisation dawned that stability and economic growth could not be restored through repression alone. ${ }^{2}$ Reform was needed.

The industrial arena was the obvious starting point for forestalling a full-blown crisis. In July 1977, Prime MinisterVorster appointed the Wiehahn Commission of Inquiry into Labour Legislation to investigate and make recommendations regarding all existing labour legislation in South Africa. The Commission was requested to submit interim reports 'in view of the urgency of the matter'. ${ }^{3}$ 
After nation-wide consultation with stakeholders from industry, organised labour, government and civil society, the Commission tabled its first and most important report in Parliament on Labour Day 1979. In a historic move, it recommended the dismantling of the apartheid labour dispensation, starting with the abolition of race-based job reservation and the legal recognition of African trade unions. These proposals envisioned, for the first time in South Africa's history, an integrated system of labour relations in which African workers would be given a seat at the table in labour negotiations and industrial councils. ${ }^{4}$

These recommendations were celebrated - not least of all internationally as major reforms. ${ }^{5}$ But local labour observers, and scholars subsequently, were quick to point out the limitations and underlying political objectives of the new labour dispensation. Centrally, the reforms sought to forestall the radical politicisation of the African labour force. In order to gain legal recognition and admittance to the industrial conciliation system, African unions were required to register with the newly created Department of Manpower, and subject their activities and finances to its scrutiny. In this way, the state sought to gain control over the unions, prohibiting direct association with political movements, donations from foreign anti-apartheid organisations or liberation movements in exile, and restricting labour mobilisation to the workplace so workers would not unite with other groups to challenge white rule. In this way, labour relations would be depoliticised. Moreover, the state initially sought to grant labour rights only to Africans permanently residing in the cities, while continuing to exclude the bulk of the black labour force seen as migrant workers from the black homelands. This new politics of inclusion, it was hoped, would give socalled urban Africans a stake in the system, secure their allegiance to the state granting them industrial citizenship, and consequently see them relinquish any further claims to full citizenship. ${ }^{6}$ In this sense, labour reform foreshadowed later constitutional changes, which sought, in turn, to co-opt South Africa's coloured and Indian minorities by granting them the political power to elect their own representatives and preside over certain circumscribed community affairs. This aimed to imbue the system with some much-needed legitimacy while still leaving overall white political dominance in place. ${ }^{7}$

White capital, too, stood to benefit from labour reform. While the conditions created by racial oppression had long suited capitalist interests, the economic slowdown of the 1970s saw the constraints of racial capitalism shift to outweigh its benefits: the exploitation of the majority black population not only inhibited the development of wider domestic markets but increasingly led to labour unrest. Moreover, racial discrimination obstructed the effective utilisation of labour. While awareness of the political and economic hazards created by racial capitalism came unevenly to South African capital, the business community had become a major advocate of reform by the time Wiehahn was appointed. ${ }^{8}$ From this point of view, the Commission's recommendation to scrap race-based job reservation would finally remove statutory obstructions to the reorganisation of labour, while industrial citizenship would deliver an acquiescent and more productive black labour force - and hence get the economy back on track. 
Scholars have since labelled these reforms "neo-apartheid" attempts to 'remodel thoroughly the foundations of white supremacy'; a "scheme" to 'share power without losing control'; ${ }^{10}$ a new politics of inclusion and exclusion, reformulating the terms on which certain "non-whites" participated in the state in order to bolster the legitimacy of the apartheid regime and gain control over the elements challenging it. ${ }^{11}$ In his analysis of the Wiehahn inquiry, Ashforth argues that reform constituted a redefinition or reimagining of the status of urban Africans, redefining them as not in the first place black, but as workers. This served to neutralise the political nature of their demands by focusing on labour rights. ${ }^{12}$

There is a larger literature outside South Africa on labour struggles and the redefinition of citizenship in the period leading up to decolonisation and majority rule. From the mid-1930s, French and British colonial regimes were confronted with increasingly forceful strike action and political movements amongst African workers. Consequently, colonial bureaucrats were forced to reimagine African labour and implement reforms in order to pre-empt labour crises with the potential to spill over into other spheres. Cooper explains how both 'British and French governments, in quite different ways, were trying to construct some kind of junior citizenship through which colonized people could partake of some, but not all, of the qualities of a metropolitan citizen'. ${ }^{13}$ These reconceptions would provide new legitimacy for colonial governments by incorporating labour into the post-war colonial system, while at the same time serving to regain control over African workers and to separate them from other groups with which they might unite to challenge colonial rule. Ultimately, this project of reimagining labour in such a way as to serve colonial interests failed as African labour organisations seized upon the discourses and redefinitions colonial officials were employing to claim rights and entitlements. ${ }^{14}$

In South Africa, decades later, labour reforms, like later constitutional reforms, served only to highlight Africans' continued political disenfranchisement and exclusion from full citizenship. And like their British and French colonial counterparts earlier in the century, black workers seized upon the new, albeit restricted, opportunities accorded by the legalisation of African labour organisation to mobilise resistance to white domination and claim full political rights. The proliferation of black trade unions from the late 1970s led to the formation of the Congress of South African Trade Unions (COSATU) in December 1985, which united over half a million black workers around the 'inseparability of shop-floor struggles and the broader political struggle'. ${ }^{15}$ COSATU took up a central role in the liberation struggle, thus proving decisively that state efforts 'to prevent trade unions from becoming agents for political transformation in South Africa had failed'. ${ }^{16}$

But absent from such considerations of reform-era South Africa are the experiences of the country's white industrial workforce. By the 1970s, some 400,000 white workers -29 per cent of the economically active white population of 1.4 million - were organised in trade unions. ${ }^{17} \mathrm{~A}$ substantial number of Afrikaners, in particular, remained in blue-collar occupations throughout the 
apartheid period, with 38 per cent working in blue-collar positions in $1970 .^{18}$ Although they certainly formed a minority of the labour force in primary and secondary industry, these white workers represented a crucial and historically powerful part of the workforce: they held the majority of supervisory and skilled jobs, as well as a significant proportion of semi-skilled positions, and effectively controlled the organised labour movement. Within the racial state, they were also the only workers with political rights.

These white workers had long reaped the benefits of race-based citizenship in the workplace and South African society at large. Yet scholarship on the lateapartheid period examining the conflicts and interests of the white state, capital and African workers has not taken account of the implications of reform for white workers in the industrial arena. Focusing on evidence brought before the Wiehahn inquiry, this chapter investigates white workers' response to efforts to placate black political demands and accommodate the shifting needs of capital by reimagining black workers' status. This provides new insights into issues of race, labour and citizenship in the late apartheid racial state.

\section{White workers in South Africa's racial order}

Although racially discriminatory practices had long characterised colonial South Africa, the mineral revolution of the second half of the nineteenth century effected the formation of racial capitalism and the racial state. White workers' material and subjective position was closely bound up with these processes. White miners saw both the Africans, alongside whom they worked, and the mine owners, eager to substitute them for less expensive labour, as threats to their position. ${ }^{19}$ These conditions, argues Krikler, were crucial to the racial formation of white working-class identity. In the presence of a large black labour force, white workers defined themselves in relation to 'that which they were not': rightless, exploited and racially despised blacks. Threats to their position thus raised interconnected fears of being thrust into poverty and of losing their racial identity. ${ }^{20}$

Efforts to replace white with black labour led to violent industrial conflict in the first two decades of the twentieth century, with white workers demanding race-based protection from capital's efforts to undermine the colour bar. ${ }^{21}$ In 1924, the Industrial Conciliation Act established an industrial relations system through which employers' organisations and trade unions could negotiate the peaceful resolution of industrial conflicts. The Act expressly barred Africans from these structures by excluding them from joining trade unions. Thus, unionised workers - whites, but also other minority race groups - were given the power to negotiate for the racial allocation of the most favoured jobs and working conditions. In subsequent years, governments expanded social security and job opportunities reserved for whites, and legislated for the payment of higher "civilised labour" wages to unskilled white workers. ${ }^{22}$ These developments are understood as serving to co-opt white labour into formal, statecontrolled structures of power. Thus emerged the outlines of a moral economy 
in which political elites bestowed protection and privilege on white workers in exchange for their political support. ${ }^{23}$ This served to diffuse class tensions within the white population, binding white workers into a social order which emphasised their racial identity and elevated them on this basis.

This process was given a particular ethnic character when the National Party (NP) came to power in 1948. Described as a "class alliance" between Afrikaner petty bourgeois, working classes and farmers ${ }^{24}$ the NP rose to popularity with its calls for greater racial segregation and "apartheid" in the wake of growing concerns about poor "whiteism" during the Great Depression, and the acceleration of African urbanisation as South Africa's manufacturing industry grew during the Second World War. Once in power, the NP set out to bolster racial privilege in the labour arena. ${ }^{25}$ Its 1956 Industrial Conciliation Act extended existing provisions for race-based job reservation and forbade the registration of new multiracial trade unions. Existing multiracial unions were ordered to split into separate branches for white, coloured and Indian workers, with only whites serving on union executives. These measures secured white leadership of the organised labour movement while weakening the bargaining position of other workers included in the industrial relations system. ${ }^{26}$ Key sections of organised white labour, such as mining production workers, enjoyed ready access to government ministers and party executives ${ }^{27}$ reflecting the moral economy of mutual obligation and reciprocity between white workers and the dominant classes of the apartheid state.

These labour determinations formed part of the NP's broader efforts to statutorily impose a social hierarchy in which racial identity determined every aspect of political, economic and social life and formed the basis of inclusion and exclusion in the racial state. The NP's policy of separate development entrenched the correlation between race and citizenship. ${ }^{28}$ The 1950 Population Registration Act divided the South African population by race, subdivided, in turn, into ostensibly distinct ethnic units, and the 1959 Promotion of Bantu Self-Government Act determined that separate black ethnic "nations" would be led to "full development" and "full authority" in their "own areas". ${ }^{29}$ This scheme sought to split the black majority into a collection of ethnic minorities, depriving those in the rural areas of their South African citizenship through self-government, and thus securing white political dominance in the Republic. It made no provision for Africans residing in South Africa's "white" cities, or for the country's coloured and Indian communities. ${ }^{30}$ This policy, explains Dubow, saw apartheid evolve "from the pronouncement of white domination ... to an elaborate and obfuscatory ideology of "multi-national" development'. ${ }^{31}$

In 1970s, the Bantu Homelands Citizenship Act sought to expedite this process. Africans residing in the cities were now also deemed to belong to a specific ethnic homeland, and hence deprived of their South African citizenship. The Bantu Homelands Constitution Act, passed in 1971, placed all homelands on track to political, executive and judicial self-government. In the course of the next seven years, eight homelands achieved this status. In this way, Pretoria sought to further safeguard white power by engineering an artificial white 
majority. ${ }^{32}$ By 1978, Minister of Plural Relations Connie Mulder could confidently state in Parliament that

[i]f our policy is taken to its logical conclusion as far as black people are concerned, there will be not one black man with South African citizenship. [...] Every black man in South Africa will eventually be accommodated in some independent new state in this honourable way and there will no longer be a moral obligation on this Parliament to accommodate these people. ${ }^{33}$

By the 1970s, therefore, the South African government was more forcefully than ever promoting a politics which 'embedded ideas of differential nationhood and citizenship' based on race. ${ }^{34}$

In the labour arena, racial citizenship translated into established privileges and protection for white workers. This is not to say, however, that all white workers supported this system fully. Factionalism along racial and ideological lines had long characterised the South African labour movement. While the NP's exploitation of white working-class fears, as well as the legislation it implemented once in power, had been quite successful in suppressing socialist tendencies amongst organised labour, different views remained on the desirability of a multiracial labour movement. The 1956 Act's restrictions on multiracial unions consequently saw organised labour fracture into two main camps. The Trade Union Council of South Africa (TUCSA) represented mostly multiracial industrial unions and craft unions in the commercial and manufacturing sectors. Membership was restricted to registered unions, but TUCSA maintained liaison ties with African workers. The South African Confederation of Labour (SACLA), in contrast, represented the racially exclusive industrial unions in older industries such as mining, steelworks and the railways, as well as a number of predominantly Afrikaner craft unions in construction and state employment. The NP-supporting SACLA opposed multiracial industrial unions and any form of African labour organisation. ${ }^{35}$

By the time the Wiehahn Commission was appointed in 1977, SACLA represented some 200,000 white workers, or about 31 per cent of the organised labour force. TUCSA, in turn, represented around 223,000 workers, of whom the majority were coloured, some were Indian, and about 58,000 were white. As per statutory determinations, TUCSA was white-led, even though the complexion of its leaders was representative of only 27 per cent of its members. ${ }^{36}$

This chapter focuses on SACLA and its affiliated unions' response to the prospect of labour reform - not only because SACLA was the most substantial representative body of white workers at the time, but also because a focus on this section of organised labour offers the opportunity to investigate how those white workers historically most invested in South Africa's racial order responded to the prospect of labour reform. Given existing scholarly understandings of how white workers contributed to the making of the racial state, and how their identity formation and material position was intricately bound 
up with the conditions of its making, this chapter seeks to investigate how these workers responded to the possibility of reform as the unmaking of racial privilege in the labour arena. Faced with the crescendo of African resistance and the changing needs of capital in the late 1970s, how did white workers articulate their identities and claims? What does this reveal about the politics between dominant and subaltern white classes at a time when the very basis of white supremacy was being reformulated? And what can this tell us about race, labour and citizenship at this crucial historical juncture?

This chapter addresses these questions by examining SACLA workers' testimony before and participation in the Wiehahn Commission of Inquiry into Labour Legislation. It draws on the Commission's extensive documentary archive, comprising written representations and comments received from various stakeholders, as well as some 10,000 pages of verbatim minutes from the oral testimony and deliberation meetings of the Commission, conducted between 1977 and $1980 .{ }^{37}$ This evidence offers new insights as to the class conflicts produced within white society in the political economic context characterising the late apartheid era, and into the entanglement of race, labour and citizenship in South Africa. This contributes to the intellectual project of rethinking white societies in Southern Africa by probing the shifting fortunes of white subalterns vis-à-vis changes in the structure of capitalism and the nature of the state under white minority rule, moving towards a deeper understanding of the manner in which class position coloured racial standing in the racial state.

\section{Race, labour and citizenship in international perspective}

A body of scholarship on white workers in the United States, emerging from the work of a new generation of labour historians in the 1990s, highlighted white working-class investment in republican citizenship amid black disenfranchisement. David Roediger's landmark 1991 book, The Wages of Whiteness, is representative of these scholars' approach which sees "white" itself as a racialised ideology, socially and historically constructed and hence in need of critical examination. Roediger, examining industrialising America in the period between the Revolution and the Civil War, tracks the ways in which white working-class identities took shape in this context marked by capitalist labour regimes, black enslavement and the revolutionary ideals of independence and freedom. White workers compensated for their anxieties about becoming dependent on wage labour by forming a self-image which brought together race, free labour and citizenship, framing themselves as the antithesis of the disenfranchised black slave. White working-class opposition to abolition, for instance, was therefore not simply a factor of anxieties surrounding potential job competition from emancipated slaves, but reflected a commitment to the equation of whiteness and citizenship. Roediger thus highlights 'the construction of identity through otherness' ${ }^{38}$ and encourages scholars to connect, rather than separate, race and class in considering identity formation and the dynamics 
of race relations. Jeremy Krikler's work on white working-class identity in early industrial South Africa, mentioned earlier, draws closely on Roediger. ${ }^{39}$

David Montgomery's Citizen Worker is also focused on antebellum America and shares the attention to white working-class agency evident in Roediger's work. With universal manhood suffrage preceding industrialisation in the USA, Montgomery investigates what advantages democracy and political rights provided workers in resisting the exploitative and restrictive aspects of emerging free market relations. Of course, political rights were the privilege of white men in this context - and while Montgomery notes that workers' claims to political rights and the equality of men were 'framed a nascent awareness of class conflict in the vocabulary of patriotism, race and rights', ${ }^{40}$ his analysis has little to say about race relations and the racialisation of working-class identity. Rather, its strength lies in examining working-class appeals to citizenship and rights as a response to the conflicts and tensions generated by capitalism, both inside and outside the workplace.

Appeals to citizenship were still a productive recourse a century later during the Great Depression, as Eric Meeks's work demonstrates. Examining the Arizona cotton industry between 1929 and 1945, Meeks shows how unemployment and poverty produced an influx of poor whites into low skill low wage jobs traditionally associated with Mexican labour. Resultant anxieties about these whites' ability to maintain their racial status saw the emergence of appeals to citizenship legitimising anti-immigration campaigns, as well as government support and employment favouritism for poor whites. This conflation of national identity with race was highlighted in cases where Mexican Americans were cast alongside immigrant Mexican workers as foreigners - indicating the importance not just of birthplace or political loyalty, but of race and culture. Arizona's 'white citizen workers' sought to distinguish themselves from Mexicans of similarly low socio-economic status by casting themselves as "good citizens", that is, independent men capable of providing for their families, and imagining Mexicans as lazy, dependent and unreliable. Such distinctions not only sought to mitigate class, race and gender anxieties, but also served to legitimate a broader racialised social order. ${ }^{41}$

Issues of citizenship have also recently attracted close attention in the field of African Studies, both in historical and contemporary perspective. Two edited volumes capture this well. Dorman et al. place the dynamic of 'making nations [and] creating strangers' central to analyses of the politics of nationalism and ethnicity shaping citizenship contestations in post-colonial Africa. In a context marked by economic distress, state failure or reconstruction, contestations over material resources such as land, opportunities or jobs are often 'potent and meaningful for their contestants because they are framed and understood in terms of identity and belonging'. ${ }^{42}$ The construction of citizenship as defining who is included in the body politic, the authors argue, is therefore necessarily entwined with processes of othering and exclusion - the creation of strangers. Most recently, Africanists have raised an argument against a narrow understanding of citizenship which invariably casts African colonial history 
in terms of a minority of citizens and a majority of subjects. This common dichotomy needs to be destabilised, they argue, by looking beyond merely formal legal definitions to everyday experiences and expressions in the engagement between people and the state. ${ }^{43}$ This may reveal how citizenship is more than a legal category, but a 'political condition that is constructed and contested by agential political subjects', ${ }^{44}$ revealing that 'there have always been different sorts of subjects'. ${ }^{45}$

Insights from this broader body of scholarship may be brought to bear productively on this investigation into white workers' response to the prospect of reforms to the race-based labour dispensation of late apartheid South Africa.

\section{Separate development: race and rights converge}

For the first two decades of its existence, the all-white SACLA was the NP's sweetheart labour confederation, supporting and enjoying the benefits of the government's racist labour policies. ${ }^{46}$ But in the course of the 1970s, the Confederation grew increasingly concerned about the threat that escalating economic and political challenges posed to white workers' interests. During his address at the Confederation's annual congress in June 1976, SACLA president Attie Nieuwoudt stated that white workers feared an 'onslaught' on their positions amid efforts to facilitate African advancement. ${ }^{47}$ Minister of Labour Fanie Botha, guest speaker at the congress, responded with the assurance that white workers would not lose their privileged position. Although some labour reforms were being planned, Botha reassured the Confederation's members that job reservation would be retained, and reaffirmed the established relations of mutual obligation binding politicians and white workers: 'Any developments in the future will be something we plan together', ${ }^{48}$ he promised.

The very next year, however, Botha appointed both an Industrial Tribunal, to report on the functionality of all existing job reservation determinations, and the Wiehahn Commission, to investigate the entire labour relations system. The Tribunal reported as the Commission was still finding its feet: 18 of the 25 job reservation determinations in force in 1976 were cancelled, and two suspended. Only five reservations remained in force - apparently where strong whites-only unions had been able to lobby for their retention. In the mining industry, for instance, both the Mineworkers' Union (MWU) and Underground Officials' Association (UOA) had argued against the removal of determination number 27. The UOA represented the 1,600 white workers responsible for the sampling, surveying and ventilation work reserved for whites by this determination, while the MWU's members, in the production side of mining, worked under these officials. ${ }^{49}$

Amid escalating local and international pressure for the abandonment of apartheid, these developments created a climate of expectancy and uncertainty ${ }^{50}$ For the white workers of SACLA, these reformist moves stood in stark contrast to established practices and Minister Botha's promises of continued white protection and partnership. Hence, as the Wiehahn Commission started 
its inquiry, it was perceived as a real moment in which the future shape of South Africa's labour dispensation was at stake.

SACLA's deputation before the Commission was led by its general secretary, Wessel Bornman of the South African Iron, Steel and Allied Industries Union. In addition to Bornman, the deputation included workers from the railways, public service and mining industry. A number of these unions also testified individually. The written submissions and oral testimony presented by SACLA and its affiliate unions were united around the retention of the existing race-based labour legislation. As the Commission's questioning returned time and again to the two most contentious issues characterising the apartheid labour dispensation - race-based job reservation, and the exclusion of African workers from the machinery of industrial conciliation through the denial of trade union rights - SACLA workers consistently based their arguments on the policy of separate development and its objective of creating black states separate from "white South Africa". SACLA workers drew a distinction between themselves, as citizens entitled to state protection and privilege in their own country, and Africans as "gasarbeiders" - guest workers or foreign labour temporarily employed in the Republic without any claim to rights or residence. White workers insisted that even Africans permanently residing in South Africa remained 'connected to their homelands' and hence foreigners who could not exercise rights in the Republic or insist on inclusion within its industrial conciliation machinery. ${ }^{51}$ This did not amount to discrimination, SACLA insisted, but accurately reflected separate development and the government's intended blueprint for the country's future. '[T] his is the ultimate goal in white South Africa, that no Bantu will have any right in South Africa', ${ }^{52}$ explained Arrie Paulus, general secretary of the MWU. Paulus pointed the commissioners to pronouncements in Parliament to support his claim: '[I]t was repeated [in Parliament] the other day that, once separate development has been fully implemented, there won't be a single Bantu that can claim South African citizenship', he stated, paraphrasing the minister of plural relations. The MWU was prepared to accept the full consequences of such a political dispensation:

I will go a step further, should a mine fall within a homeland, [. . .] that independent government makes its own laws, and if there should come a day when it decides to change its legislation so that a certain job becomes reserved for blacks, then I won't go argue that whites are being discriminated against, because it is their privilege to amend those laws. ${ }^{53}$

But in "our country", insisted Paulus, black workers remained outsiders without any claim to citizenship. ${ }^{54}$

This politics of inclusion and exclusion - framing themselves as citizens included in the body politic and blacks as outsiders with no claims to rights formed the foundation of SACLA workers' arguments against reform. When it came to the question of whether African trade unions should be legally recognised in South Africa, these white workers consistently called for the banning of 
African trade unions in the Republic: black workers could exercise their labour rights 'in their own country', and any efforts to organise in South Africa should be criminalised and prosecuted. ${ }^{55}$ One SACLA delegate demanded that African unions should be outlawed in South Africa because the country's political and legal arrangements should not be made subservient to employers' desire to negotiate with black workers. ${ }^{56}$ Similarly, when it came to the question of whether labour legislation should make provision for race-based job reservation, these workers again appealed to racial citizenship. The SACLA deputation stated that it considered job reservation a 'matter of the principle of the protection of interests ${ }^{57}$ and the 'self-preservation of the white worker in his own country'. ${ }^{58}$ The MWU, whose members had long benefitted from the reservation of blasting certificates for white miners, also forcefully defended job reservation, denying that it discriminated against black workers who were immigrants to 'white South Africa' with no claims to rights in the country. ${ }^{59}$ Bornman's metalworkers' union expressed similar convictions. It testified to receiving a mandate from its members to call for the state to give 'absolute preference to the utilisation of all available whites'. Thereafter, the state should prioritise matters of automation, and only then should it attend to the needs of "other" workers. ${ }^{60}$ It is clear that for these workers, neither the interests of capital, nor those of black workers, should take precedence over the interests of whites as citizens of the racial state. Given the reality of separate development, in which race and rights converged, this did not amount to discrimination but fulfilled the function of labour law and obligation of political elites in white South Africa of protecting citizen workers. ${ }^{61}$

Interestingly, white workers' rhetoric of inclusion and exclusion departed from the established racial logic of apartheid. For decades, opponents of trade union rights for black workers argued that Africans were not "ripe" - sufficiently mature, educated or civilised - to "handle" industrial citizenship. ${ }^{62}$ But by the late 1970s, white workers could no longer invoke this racial logic to oppose reform: representing black workers as unfit for labour or political rights would undermine the policy of separate development which sought to grant Africans independence in their own countries. While older ideas of black barbarism did occasionally crop up in some testimonies - the MWU characterised black mineworkers as 'from the bush' ${ }^{63}$ - these were few and far between. Rather, the centrality of separate development to white workers' defence of the racist labour dispensation meant that, for the most part, they were firmly committed to an understanding of blacks as citizens - but only outside "white South Africa". Such claims demonstrate the limits of apartheid's efforts to engineer a white majority in South Africa - white workers were clearly extremely aware of their minority status in the workplace.

\section{Class and racial citizenship}

During their testimony to the Commission, white workers outlined the dangers which removing protective legislation would pose to them as worker 
citizens. The SACLA deputation explained that job reservation offered protection from 'exploitation' ${ }^{64}$ arising from 'the capitalist businessman and his pursuit of maximum profit at minimum cost [which] will always seek out the cheapest labour' in the form of 'some other races' with 'lower living standards' ${ }^{65}$ For the MWU, too, protection was necessitated by the presence of a large cheap black labour force:

Employers have but one goal namely to secure ever greater profits. The easiest way to accomplish this is to make use of cheaper labour. The living standard of the non-white in South Africa is much lower than that of the white, making it easy to employ non-whites for lower remuneration. Should job reservation be removed, this will be to the advantage of the employer. ${ }^{66}$

Asked whether unions would be able to protect minorities, should job reservation be abrogated, SACLA's Bornman answered with a resounding 'no'. ${ }^{67}$ Crucially, therefore, these threats which white workers perceived were not in the first place racial, but capitalist in nature.

A further dimension of this was revealed during the testimony of Bornman's metalworkers' union in its own capacity. This deputation defended job reservation particularly on behalf of lesser-skilled economically vulnerable white workers:

As far as the job reservation determination is concerned [...] it is [protecting] specifically those people who do not have a trade that are rooted in these industries and who, should they leave, would be completely incapable of finding a similar income off [sic] their own accord anywhere else in the job market. ${ }^{68}$

This statement seems reminiscent of the policy of "civilised labour" - offering inflated wages and insulation from competition to white workers with relatively few skills. Indeed, the South African Iron, Steel and Allied Industries Union historically represented unskilled and semi-skilled white workers, many of whom were employed as production workers and operatives in the parastatal steel company Iscor, established in 1928. By 1976, this union represented some 38,000 workers across the industry. ${ }^{69}$ For them, job reservation concretised the state's responsibility to protect its citizens - particularly those who were vulnerable.

As a member of the Wiehahn Commission, SACLA president Attie Nieuwoudt also displayed concern with the economic vulnerability of some of the workers he represented, and their consequent dependence on statutory protection. This was tellingly demonstrated during a deliberation meeting on the Commission's draft Report when Nieuwoudt objected to references to poor whiteism in its historical overview of South Africa's labour legislation:

NIEUWOUDT: Mr Chairman, down here we refer to the poor white question, is it really necessary to mention this?

WIEHAHN: But this poor white question was part of our history, Mr Nieuwoudt. 
NIEUWOUDT: It can become part of [our] history again.

WIEHAHN: Sure, it can always become part of history and then other commissions in a hundred years can refer to it again.

NIEUWOUDT: Mr Chairman, it might be within ten months.

WIEHAHN: It is but history, Mr Nieuwoudt, simply a factual statement in historical interest. $^{70}$

The SACLA president knew that within the fold of his organisation, white poverty featured prominently in the historical consciousness of white workers particularly in older industries which had earlier in the century absorbed large numbers of unskilled and impoverished whites as "civilised labour". Indeed, Nieuwoudt's words show that the spectre of white poverty was perceived as a present reality. For SACLA workers, the prospect of labour reform suggested that the racial order could be reversed. This conjured up not just the prospect of job insecurity, but the very conditions of their class formation, which saw their whiteness and inclusion in the racial state offer them protection from the degradation of white poverty and the exploitation of capitalist employers. In this social order, it was their very citizenship which distinguished them from blacks and warranted their privileged position. Labour reform imperilled this.

In his study of white working-class identity in antebellum America, Roediger argues that racism was not just about economic position, but also about how white workers saw the world and themselves in it. In the case of late apartheid South Africa, white workers' opposition to reform clearly reflected their class interests and investment in the protection they enjoyed from capitalist exploitation. But it also reflected how they perceived the world and their position in it: they were whites, citizens, and therefore entitled to rights, while blacks were foreigners and had no claim to whites' country. This doctrine was not just their own; it was the official mantra of the South African government. For white workers, their class position rendered the rights and privileges of racial citizenship all the more precious, and the conditions of their class formation meant the distinction which racial citizenship drew between whites and blacks was fundamental to their identity and self-image. Recall Krikler's argument that white workers defined themselves in opposition to rightless, exploited and racially despised blacks. ${ }^{71}$ Reforming the county's race-based labour dispensation by granting Africans industrial rights would not only threaten white workers' job security, but their very self-image. Just weeks before the Wiehahn Commission released part one of its Report, MWU president Cor de Jager, speaking at the union's annual congress, expressed the fear that 'we [white workers] will become gasarbeiders in our own country'. ${ }^{72}$ White workers' anxieties around poor whiteism, exposure to capitalist exploitation, and of themselves becoming gasarbeiders all point to instances of their relegation to social positions historically and contemporarily associated with precarious whiteness, or blackness. More than just material and political implications, reform thus went to the heart of white working-class identity. Nic Wiehahn, in his exchange with Attie Nieuwoudt, seemed oblivious to this class dimensions of racial citizenship. He 
dismissed Nieuwoudt's objection as a matter of historical semantics, and did not register the much more fundamental, long-lived anxieties which it revealed.

\section{The politics of reform and the disruption of the moral economy}

In their testimony to the Wiehahn Commission, SACLA workers consistently emphasised that labour reform was not in the first instance an economic matter - it was a political one. The SACLA deputation insisted, for instance, that any issues around the employment conditions of African "guest workers" should be dealt with as matters of "interstate relations" - that is, addressed at a political level, between the government of South Africa and the relevant bantustans and employers involved. ${ }^{73}$ Later, when asked whether job reservation should be abolished, as this arrangement was detrimental to the national economy, the SACLA deputation responded that the economy was 'an entirely different matter ${ }^{74}$ - under discussion were matters of citizenship and political entitlement, rather than economic considerations. Recall, similarly, the metalworkers union's demand that the state make the utilisation of all available whites its first priority, followed by automation, and then 'the needs of others'. When this submission elicited an animated round of questioning regarding the state's responsibilities towards its coloured and Indian population, general secretary Bornman responded by stating that the testimony simply reflects existing government policy and the union's own priorities. 'We are not experts on the economy', he added. ${ }^{75}$ As with the view that African trade union rights were a matter of "interstate relations", this comment demonstrates how white workers regarded labour policy as a political rather than an economic issue. And as far as SACLA workers were concerned, the political arrangements of separate development should be replicated in all spheres of life, including labour arrangements, irrespective of economic imperatives.

By continuously asserting their position as citizens of the racial state, appealing to the policy of separate development, and repudiating efforts to represent labour reform as a primarily economic issue, these white workers were resisting the depoliticising thrust of the reform process. When the MWU deputation was asked to consider alternative measures which might replace statutory protection, Paulus refused to participate in such efforts to depoliticise the matter. Alternative measures would still amount to job reservation and therefore still attract the ire of the international community. It would be much better for South Africa to 'call a spade a spade' and defy the foreign opinion, which has 'no business here' ${ }^{76}$ Paulus and the workers he represented accepted that the maintenance of racial citizenship would have political ramifications, and found these to be preferable to the alternative. Claims to white workers' entitlement and belonging to the white body politic reflected their insistence that the existing practices of obligation and reciprocity between different parties in this body politic be upheld.

The fundamental entanglement of labour and politics meant that these workers' testimonies highlighted the contradiction inherent in attempts at labour 
reforms, namely that African workers could be granted industrial without political citizenship. Indeed, white workers in the SACLA fold were the only group to impress upon the Commission the potential political ramifications of this strategy: granting industrial rights to Africans would be the thin end of the wedge and offer Africans avenues for demanding and seizing full citizenship. This was expressed most clearly by SACLA president Nieuwoudt. As a member of the Wiehahn Commission, Nieuwoudt echoed his confederation's views, similarly stressing that labour matters and potential reforms functioned within a broader political context and had to adhere to official state policy. Already at the outset of the inquiry, he had stated his commitment to this social order, ${ }^{77}$ and throughout the investigation, he was unwilling to debate any measures deviating from it. ${ }^{78}$ In the closed deliberation meetings following the Commission's testimony hearings, we find Nieuwoudt continually defending his commitment to job reservation for 'the white worker in his own country' and the denial of union rights for African workers in the Republic as arrangements which South Africa's policy of separate development demanded:

[M]y Prime Minister [Vorster], who is now retired, had me in his office where I had a long conversation with him and he explained everything very clearly. Mr Chairman, he said that the black man would get his own republic where he would be master and have the vote and where he could govern in the way that the world wishes him to govern, as a sovereign nation. ${ }^{79}$

For Nieuwoudt and the workers he represented, labour went hand in hand with matters of political power and citizenship so that rights and privilege in the industrial sphere could not be divorced from rights and privilege in the political sphere. By pointing to Africans' imminent "mastery" in their own countries, Nieuwoudt's statement suggests his anxiety about the implications for white rule in South Africa, should Africans be granted labour rights. Thus, as the Commission's deliberation meetings continued, Nieuwoudt continually and urgently directed his fellow commissioners' attention to the potential political ramifications of labour reform: on one occasion he implored them to consider 'where are we going with this fatherland of ours', $; 0$ on another, he warned that 'we are busy deciding about the future of South Africa here, because the labour force will determine our direction, and politics will just have to follow suit'. ${ }^{81}$ These same concerns underlay SACLA unions' insistence on the political nature of reform and its consequences. The South African Iron, Steel and Allied Industries Union even concluded its testimony by drawing the Commission's attention to the role of black unions in the liberation struggle of various African countries. ${ }^{82}$ White workers recognised and warned that labour reform would mark the beginning of the end for the racial state. Many years later, Wiehahn commissioners drawn from academic and business circles admitted that white workers had been much more attuned to the possible political ramifications of labour reform than commissioners from other social spheres ${ }^{83}$ 
It is unsurprising that white workers would have been most sensitive to the possible ramifications of reform. Industrial citizenship for Africans called the established convergence between race and rights into question - if blacks could be given rights, whites could have them taken away. This understanding is evident throughout SACLA workers' testimony to the Commission: they did not see potential reforms as awarding black workers rights alongside white workers, but as blacks gaining rights at the expense of white workers. For white workers, the uncoupling of race from rights implied the potential of exclusion from racial citizenship. To be sure, there were no indications that the political system was going to change fundamentally and overall white rule was set to continue in South Africa. For white workers, the prospect of labour reform therefore placed both their position of economic vulnerability as well as their identities as citizen workers at risk in a context in which other whites would retain their privileges within the racial state. Hence it was this citizenship to which they appealed unceasingly. Towards the end of the metalworkers' union's testimony, chairman Wiehahn posed a final question:

WIEHAHN: But suppose there would be overwhelming evidence in a different direction [to that presented by the union, for the retention of a race- based labour dispensation], do you expect your union's views to be decisive, or do you expect the Commission to simply take cognisance of your union's views? [. . . I would just like to know your general view on the matter.

BORNMAN: Mr Chairman, I suppose every person would like to see his views upheld, and this is the case for us also. If we should be in the minority on the issue - PAUSE

WIEHAHN: Not that this would necessarily be the case. BORNMAN: We have always been good citizens. ${ }^{84}$

These statements concluded the session. Confronted with the real prospect that white workers might lose their privileged position, Bornman appealed to the established moral economy. He implored the Commission, as proxy for the state and the political elite, to consider the political loyalty and industrial discipline white workers had shown the National Party, their role in maintaining the key pillars of a racially ordered society and bolstering white power in South Africa - this, in exchange for state support and protection of their position as part of this racial order. White workers had 'always been good citizens', Bornman reminded the Commission, and this relationship had to be honoured.

But the government had other plans. Shortly after the Commission released its first report, the NP accepted recommendations to scrap job reservation and legalise African unions. In a revealing statement which echoed Bornman's appeal, MWU general secretary Paulus lambasted the government for betraying white workers: 'in accepting the Wiehahn report, the government has committed the greatest act of treason against the white workers of South Africa since 1922, when hundreds of miners were shot because they rebelled against the Chamber of Mines' efforts to force them to share their work with blacks' ${ }^{85}$ For 
the MWU, reforms thus recalled earlier struggles for recognition, protection and status as white citizens in the racial state. The state had withdrawn its support for working-class whiteness.

\section{Rethinking reform}

Of course, as indicated earlier, not all sections of the organised labour movement sought the maintenance of the apartheid labour dispensation. The multiracial labour federation TUCSA claimed to welcome moves towards reform - although the Council suffered from a great deal of internal division on the subject. Overall, its leadership took a reformist stance, supporting the removal of discriminatory legislation and the granting of trade union rights to Africans, subject to strict state regulation. TUCSA representatives did not draw the same links between labour rights and citizenship as their SACLA counterparts, and generally echoed the depoliticising rhetoric of reformist politicians. ${ }^{86}$ It has been suggested that TUCSA was hoping to incorporate African workers into its structures, thereby gaining control over African unionism in this way instead of through legislative means, as SACLA wanted. ${ }^{87}$

This different strategy may be ascribed to the different kinds of workers represented by the two federations. Not only did SACLA represent far more whites than TUCSA, but its members also 'owed their privilege - sometimes their very jobs - to direct government intervention. It was strongest either on the railways and in state-owned steel plants, which were created partially to offer whites protected jobs, or on the mines where white workers relied on job bars in the law to bolster their privilege. Its members had no skilled trade to protect them' ${ }^{88}$

SACLA workers' resistance to reform, as articulated in the course of the Wiehahn inquiry, provides new insights which challenge existing understandings of reform-era South Africa. Scholars regard late apartheid reforms as part of a "scheme" to remodel the foundations of white supremacy - yet it clearly did not enjoy the support of all whites. The scheme's new politics of inclusion and exclusion threatened white workers' position and identity as citizens of the racial state. Indeed, if reform constituted a redefinition or reimagining of the status of urban Africans, as Ashforth argues, it follows that this would also entail the redefinition of the status of white workers whose very position relied on the exclusion of Africans from the privileges of industrial citizenship, and whose identity was intimately bound up with the rightlessness of blacks. Reform heralded the start of the withdrawal of state support for working-class whiteness. As a "scheme" to 'share power without losing control', it did not include white workers. Moreover, in the context of economic and political crisis and the shifting priorities of capital and the state, this "scheme" instigated the destruction of the established moral economy.

This alerts us to the class conflicts produced within white society by the political challenges and shifting capitalist imperatives of the late apartheid period. Existing scholarship is mainly focused on the tensions between the white state 
and the black populace. And while scholars recognise that by the 1970s the NP's priorities had drifted away from its original agricultural and working-class support base towards middle-class suburbanites and business interests, ${ }^{89}$ little sustained attention has been paid to the intra-white class conflicts and implications of this historical juncture. Contestations around inclusion and exclusion evident in SACLA workers' testimony to the Wiehahn Commission therefore point us towards previously overlooked dynamics of the politics of reform and the process of state remaking and status renegotiation it entailed. Scholars have suggested that by the 1970 s, whites no longer needed a racially discriminatory framework to maintain their privileged position..$^{90}$ Yet SACLA workers' reactions to the prospect of reform during the Wiehahn process reveal the continued importance of racial privilege and protection to a substantial part of the white working class. By pointing to capitalist exploitation, the economic vulnerability of lesser-skilled whites and the threat of white poverty, white workers demanded continued state protection. Their commitment to separate development and their anxieties about reform reducing them to gasarbeiders expressed very different priorities to those pursued by the white state and business leaders. Historians therefore need to reconsider their understandings of white interests in the late apartheid period to include the continued importance of whiteness to subaltern whites.

In considering the entanglement of race, labour and citizenship in late apartheid South Africa, white workers' response to the prospect of reform reveals how class position impacts citizenship. Hunter, commenting on the misleading notion of a minority of citizens versus a majority of subjects in understandings of African colonial history, points out that 'there have always been different sorts of subjects' ${ }^{91}$ - and, as this chapter shows, different sorts of citizens.

\section{Notes}

1 Lodge, 'Resistance and Reform', 409-491.

2 Lodge, 'Resistance and Reform'; Worden, The Making of Modern South Africa, 128-130, 132-136.

3 Department of Labour and of Mines, Report of the Commission of Inquiry into Labour Legislation Part 1 (Key Issues). Pretoria: Government Printer, RP49/1979, v.

4 Coupe, 'Labour Relations by Authoritarian Regimes Since 1945', 14.

5 Friedman, Building Tomorrow Today, 155.

6 Industrial sociologists and labour historians invoke the idea of 'industrial citizenship' to refer to workers' rights to industrial representation and participation in the structures of industrial conciliation - including forming and joining trade unions, electing representatives to those organisations, and engaging in actions such as negotiations and strikes in pursuit of better employment conditions. On industrial citizenship for Africans in the context of reform-era South Africa, see Barchiesi, Precarious Liberation, 51; Lichtenstein, 'A Measure of Democracy', 113-138.

7 Friedman, Building Tomorrow Today, 156-158; Lodge, 'Resistance and Reform', 425, 437, 443-444; Giliomee, The Last Afrikaner Leaders, 147; Greenberg, Legitimating the Illegitimate.

8 Saul and Bond, South Africa The Present as History, 112.

9 Dubow, Apartheid, 297.

10 Giliomee, The Last Afrikaner Leaders, 139, 147. 
11 Posel, 'Language, Legitimation and Control'.

12 Ashforth, The Politics of Official Discourse.

13 Cooper, Decolonization and African Society, 266.

14 Ibid.

15 Lodge, 'Resistance and Reform', 454.

16 Giliomee, The Last Afrikaner Leaders, 161.

17 South African Institute of Race Relations (SAIRR), A Survey of Race Relations in South Africa 1970, 81, 126.

18 Compared to 41\% in 1946 and 29\% in 1991. Sadie, The Fall and Rise of the Afrikaner, 54.

19 Marks, 'Class, Culture, and Consciousness', 126, 132, 136.

20 Krikler, The Rand Revolt, 149; see also Johnstone, Class, Race and Gold.

21 See for instance Yudelman, The Emergence of Modern South Africa; Hyslop, 'The Imperial Working Class Makes Itself "White"; Krikler, The Rand Revolt; Katz, 'White Workers' Grievances and the Industrial Colour Bar'; Katz, A Trade Union Aristocracy.

22 Horrell, South Africa's Workers, 2-3; Feinstein, An Economic History of South Africa, 86-87.

23 Moral economy describes 'those elements of culture (customs, beliefs, and practices) that normatively regulate and legitimize the [unequal] distribution of resources such as wealth, power and honour or status in society'. It was developed in the work of E.P. Thompson and James Scott respectively as an analytical tool for analysing the relations between dominant and subordinate classes, particularly as revealed in the behaviour of the latter, caught in the transformation of one social order to another - from peasant to industrial, capitalist market economies, from pre-colonial societies to modern colonial states. Its most prominent proponents in the African context have been John Lonsdale and Bruce Berman. Berman, Laliberté and Larin, The Moral Economies of Ethnic and Nationalist Claims, 4; Thompson, The Making of the English Working Class; Scott, The Moral Economy of the Peasant; Berman and Lonsdale, Unhappy Valley; Lonsdale, 'Moral Ethnicity and Political Tribalism'.

24 O'Meara, Volkskapitalisme, 65-68, 103, 108; O'Meara, Forty Lost Years, 42, 54-57, 77-80. See also Adam and Giliomee, Ethnic Power Mobilized; Giliomee, 'Constructing Afrikaner Nationalism'.

25 Witz, 'A Case of Schizophrenia'.

26 Feinstein, An Economic History, 50; Horrell, South Africa's Workers, 16.

27 Visser, 'From MWU to Solidarity', 22.

28 The policy had its roots in the Afrikaner Nationalist belief in the distinctiveness of individual nations and their resultant right to self-determinations, as well as its commitment to Western civilisation and the maintenance of white privilege and exclusivity. See Posel, 'The Apartheid Project'; O'Meara, Forty Lost Years; Dubow, Apartheid.

29 Quoted in Giliomee, The Last Afrikaner Leaders, 76.

30 Ibid., 44, 76, 81.

31 Dubow, Apartheid, 105.

32 Giliomee, The Last Afrikaner Leaders, 89, 90, 100-101; Davenport, South Africa, 301; Dubow, Apartheid, 153.

33 Quoted in Giliomee, The Last Afrikaner Leaders, 90-91.

34 Dorman, Hammett and Nugent, Making Nations, Creating Strangers, 13.

35 Horrell, South Africa's Workers, 19-20, 30, 39; Friedman, Building Tomorrow Today, 73; Greenberg, Race and State in Capitalist Development, 296, 300-301.

36 For SACLA see South African Institute of Race Relations, A Survey of Race Relations in South Africa 1976, 313; South African Institute of Race Relations, A Survey of Race Relations in South Africa 1977, 288. For TUCSA, see South African National Archives of South Africa (hereafter NASA), K364, Volume 33, AK 6/3/1/1/4 Volume II, Documentation accompanying letter from Industrial Registrar to The Secretary, Commission of Inquiry into Labour Legislation, 10 July 1978, 1-3; NASA, K364, Volume 33 AK 6/3/1/1/4 Volume II: 'Memorandum concerning a sound labour relations system, 
submitted by the Trade Union Council of South Africa to the Commission of Inquiry into Labour Legislation, October 1977' (Memorandum Dokument No. 00147), 1.

37 The Wiehahn Commission's collection is held at the National Archives of South Africa in Pretoria. In addition, Naas Steenkamp - the only surviving Wiehahn commissioner at the time of this research - preserves a private archive at his home outside Cape Town. This private collection largely corresponds to that of the National Archives. I consulted both collections for the purpose of this research. They are variously referenced as NASA or SA/WD (Steenkamp Archive/Wiehahn Documentation) here.

38 Roediger, The Wages of Whiteness, 14.

39 Krikler, The Rand Revolt, 149.

40 Montgomery, Citizen Worker, 6.

41 Meeks, 'Protecting the "White Citizen Worker"'. See also Meeks, Border Citizens.

42 Dorman, Hammett and Nugent, Making Nations, Creating Strangers, 6.

43 Hunter, 'Introduction', 1-2, 4; See also Russell, 'Burundi, 1960-67'.

44 Balaton-Chrimes, 'The Nubians of Kenya', 167.

45 Hunter, 'Introduction', 1-2.

46 Friedman, Building Tomorrow Today, 72-73.

47 SAIRR, A Survey of Race Relations in South Africa 1977, 316.

48 Quoted in SAIRR, A Survey of Race Relations in South Africa 1976, 314.

49 SAIRR, A Survey of Race Relations in South Africa 1977, 226-227.

50 Friedman, Building Tomorrow Today, 151.

51 SA/WD, Testimony Meeting 8, Pretoria, 6 December 1977, 913, 914, 919-921; also Testimony Meeting 9, Pretoria, 7 December 1977, 1018; Testimony Meeting 24, Johannesburg, 22 February 1978, 3692-3693, 3699-3700, 3718-3719.

52 SA/WD, Testimony Meeting 24, Johannesburg, 22 February 1978, 3699.

53 Ibid., 3700.

54 Ibid., 3719; also Testimony Meeting 9, Pretoria, 7 December 1977, 1005.

55 SA/WD, Testimony Meeting 24, Johannesburg, 22 February 1978, 3716; also Testimony Meeting 8, Pretoria, 6 December 1977, 93; Testimony Meeting 8, Pretoria, 6 December $1977,924$.

56 SA/WD, Testimony Meeting 8, Pretoria, 6 December 1977, 925.

57 Ibid., 908.

58 Letter from SACLA to the Wiehahn Commission, dated 12 May 1978, quoted in SA/ WD, Deliberation Meeting 43, Pretoria, 5 September 1978, 7240.

59 SA/WD, Testimony Meeting 24, Johannesburg, 22 February 1978, 3699.

60 SA/WD, Testimony Meeting 9, Pretoria, 7 December 1977, 995.

61 SA/WD, Testimony Meeting 8, Pretoria, 6 December 1977, 923.

62 Lichtenstein, 'A Measure of Democracy'.

63 SA/WD, Testimony Meeting 24, Johannesburg, 22 February 1978, 3701.

64 SA/WD, Testimony Meeting 8, Pretoria, 6 December 1977, 909.

65 NASA, K364, Volume 33 AK 6/3/1/1/4 Volume II: SA Confederation of Labour (Memorandum Dokument No. 00164), 1; also SA/WD, Testimony Meeting 8, Pretoria, 6 December 1977, 909.

66 NASA, K364,Volume 33 AK 6/3/1/1/4 Volume II: '[MWU] Memorandum in verband met Arbeidswetgewing' (Memorandum Dokument No. 00182), 2; also SA/WD, Testimony Meeting 24, Johannesburg, 22 February 1978, 3716-3717.

67 SA/WD, Testimony Meeting 8, Pretoria, 6 December 1977, 923.

68 SA/WD, Testimony Meeting 9, Pretoria, 7 December 1977, 1004.

69 Lewis, Industrialization and Trade Union Organization, 78-83.

70 SA/WD, Deliberation Meeting 52, Pretoria, 27 November 1978, 8771-8772.

71 Krikler, The Rand Revolt, 149.

72 'Cor de Jager praat kaalkop oor inflasie en gooi MWU se deure wyd-oop', The Mineworker, 7 February 1979, 3-4. 


\section{Danelle van Zyl-Hermann}

73 SA/WD, Testimony Meeting 8, Pretoria, 6 December 1977, 925; also Testimony Meeting 24, Johannesburg, 22 February 1978, 3693, 3712.

74 SA/WD, Testimony Meeting 8, Pretoria, 6 December 1977, 918.

75 SA/WD, Testimony Meeting 9, Pretoria, 7 December 1977, 995, 1002-1003.

76 SA/WD, Testimony Meeting 24, Johannesburg, 22 February 1978, 3717.

77 Department of Labour and of Mines, Report Part 1, 4.

78 See for example SA/WD, Deliberation Meeting 46, Pretoria, 8 September 1978, 7781; Deliberation Meeting 50, Pretoria, 24 October 1978, 8364, 8485, 8539, 8549; Deliberation Meeting 54, Pretoria, 11 December 1978, 9029.

79 SA/WD, Deliberation Meeting 47, Pretoria, 26 September 1978, 8028.

80 Ibid.

81 SA/WD, Deliberation Meeting 54, Pretoria, 11 December 1978, 8987.

82 SA/WD, Testimony Meeting 9, Pretoria, 7 December 1977, 1020-1021.

83 Piet van der Merwe interviewed by Naas Steenkamp, Pretoria, 7 October 2008. Also see Piet van der Merwe interviewed by Hermann Giliomee, Pretoria, 18 March 2009.

84 SA/WD, Testimony Meeting 9, Pretoria, 7 December 1977, 1019-1020. The emphasis and PAUSE are recorded in the original.

85 Paulus 'Grootste verraad teenoor blanke werkers!', The Mineworker, 16 May 1979, 1.

86 TUCSA's testimony is contained in SA/WD, Testimony Meeting 22, Johannesburg, 20 February 1978, 3215-3287, and NASA, K364, Volume 33 AK 6/3/1/1/4 Volume II: 'Memorandum concerning a sound labour relations system, submitted by the Trade Union Council of South Africa to the Commission of Inquiry into Labour Legislation, October 1977' (Memorandum Dokument No. 00147). For a full analysis of TUCSA's position, see Van Zyl-Hermann, 'White Workers and South Africa's Democratic Transition', 75-83.

87 Friedman, Building Tomorrow Today, 75.

88 Ibid., 76.

89 O'Meara, Forty Lost Years, 78-79, 120, 139-140; Terreblanche, Lost in Transformation? 54.

90 Giliomee, 'Apartheid: A Complex Heritage'; Mariotti, 'Labour Markets During Apartheid in South Africa', 120.

91 Hunter, 'Introduction', 1-2. 


\section{Bibliography}

Adam, H. and Giliomee, H. (1979) Ethnic Power Mobilized: Can South Africa Change? Yale University Press, New Haven and London.

Adhikari, M. (ed) (2009) Burdened by Race: Coloured Identities in Southern Africa. UCT Press, Cape Town.

Adinolfi, G. and Costa Pinto, A. (2014) 'Salazar's "New State": The Paradoxes of Hybridization in the Fascist Era', in A. Costa Pinto and A. Kallis (eds) Rethinking Fascism and Dictatorship in Europe. Palgrave Macmillan, Basingstoke, 154-175.

Adonis, D.Z. (2007) 'The Public Service Association's Response to the Changes Brought About by the Public Service Labour Relations Act (102/1993)', Masters of Business Leadership Research Report, University of South Africa.

Aguiar, M. (2011) Tracking Modernity: India's Railway and the Culture of Mobility. University of Minnesota Press, Minneapolis.

Alexander, K. (2004) 'Orphans of the Empire: An Analysis of Elements of White Identity and Ideology Construction in Zimbabwe', in B. Raftopoulos and T. Savage (eds) Zimbabwe: Injustice and Political Reconciliation. Institute for Justice and Reconciliation, Cape Town, 193-212.

Almeida, A.L. de (1970) 'Colonato do Limpopo: Contribuição da Cooperativa Agrícola no Desenvolvimento Socioeconómico', BA dissertation, Instituto Superior de Ciências Sociais e Política Ultramarina da Universidade Técnica de Lisboa.

Arendt, H. (1977 [1963]) Eichmann in Jerusalem: A Report on the Banality of Evil. Penguin Books, Harmondsworth.

Arnesen, E. (2001) 'Whiteness and the Historian's Imagination', International Labor and Working-Class History, no 60, 3-32.

Ashforth, A. (1990) The Politics of Official Discourse in Twentieth-Century South Africa. Clarendon Press, Oxford.

Balaton-Chrimes, S. (2016) 'The Nubians of Kenya: Citizenship in the Gaps and Margins', in E. Hunter (ed) Citizenship, Belonging, and Political Community in Africa: Dialogues Between Past and Present. Ohio University Press, Athens, 149-178.

Ballantyne, T. (2014) 'Mobility, Empire, Colonisation', History Australia, vol 11, no 2, 7-37.

Barata, J.F.N. (1970) 'O aproveitamento do Cunene e o desenvolvimento do Sul de Angola', Ultramar, no 39, 51-73.

Barchiesi, F. (2011) Precarious Liberation: Workers, the State, and Contested Social Citizenship in Postapartheid South Africa. SUNY Press, Albany.

Barclay, F., Chopin, C.A. and Evans, M. (2018) 'Settler Colonialism and French Algeria', Settler Colonial Studies, vol 8, no 2, 115-282. 


\section{Bibliography}

Barnes, T. (1992) 'The Fight for Control of African Women's Mobility in Colonial Zimbabwe, 1900-1939', Signs, vol 17, no 3, 586-608.

Barrett, J.R. and Roediger, D. (1997) 'Inbetween Peoples: Race, Nationality and the New Immigrant Working Class', in R. Halpern and J. Morris (eds) American Exceptionalism? US Working Class Formation in an International Context. Palgrave Macmillan, Basingstoke, 181-200.

Bear, L. (2007) Lines of the Nation: Indian Railway Workers, Bureaucracy and the Intimate Historical Self. Columbia University Press, New York.

Beavon, K. (2004) Johannesburg: The Making and Shaping of the City. UNISA Press, Pretoria.

Beinart, W. (2001) Twentieth Century South Africa. Oxford University Press, Oxford.

Belich, J. (2005) 'The Rise of the Anglo World: Settlement in North America and Australia, 1893-1939', in P. Buchner and D. Francis (eds) Rediscovering the British World. University of Calgary Press, Calgary, 39-57.

Belich, J. (2011) Replenishing the Earth: The Settler Revolution and the Rise of the Anglo World, 1783-1939. Oxford University Press, Oxford.

Bender, G.J. (1973) 'Planned Rural Settlements in Angola: 1900-1968', in F-W. Heimer (ed) Social Change in Angola. Weltforum Verlag, Munich, 242-273.

Bender, G.J. (1980 [1976]) Angola sob o Domínio Português: o Mito e a Realidade. Sá da Costa, Lisbon.

Bender, G.J. (2004 [1978]) Angola Under the Portuguese: The Myth and the Reality. Africa Research and Publications, London.

Bender, G.J. and Yoder, P.S. (1974) 'Whites in Angola on the Eve of Independence: The Politics of Numbers', Africa Today, vol 24, no 4, 23-37.

Berman, B. and Lonsdale, J. (1992) Unhappy Valley: Conflict in Kenya and Africa. James Currey, Oxford.

Berman, J., Laliberté, A. and Larin, S.J. (eds) (2016) The Moral Economies of Ethnic and Nationalist Claims. UBC Press, Vancouver.

Bhambra, G.K. (2017) 'Brexit, Trump, and "Methodological Whiteness": On the Misrecognition of Race and Class', British Journal of Sociology, vol 68, S1, 214-232.

Bickers, R. (2003) Empire Made Me:An Englishman Adrift in Shanghai. Allen Lane, London.

Birmingham, D. (1999) Portugal and Africa. Palgrave Macmillan, Basingstoke and New York.

Black, A. (ed) (2016) Towards Employment-Intensive Growth in South Africa. Juta, Cape Town.

Bonello, J. (2010) 'The Development of Early Settler Identity in Southern Rhodesia: 18901914', International Journal of African Historical Studies, vol 43, no 2, 341-367.

Bonner, P. (1994) 'New Nation, New History:The History Workshop in South Africa, 19771994', The Journal of American History, vol 81, no 3, 977-985.

Bonner, P., Hyslop, J. and van der Walt, L. (2007) 'Rethinking Worlds of Labour: Southern African Labour History in International Context', African Studies, vol 66, no 2-3, 137-167.

Boonen, S. and Lagae, J. (2015) 'A City Constructed by “des gens d'ailleurs": Urban Development and Migration Policies in Colonial Lubumbashi, 1910-1930', Comparativ: Zeitschrift für Globalgeschichte und Vergleichende Gesellschatsforschung, vol 4, no 25, 51-69.

Bottomley, E. (2012) Poor White. Tafelberg, Cape Town.

Boxer, C. (1963) Race Relations in the Portuguese Colonial Empire, 1415-1825. Clarendon Press, Oxford.

Bozzoli, B. (ed) (1987) Class, Community and Conflict: South African Perspectives. Ravan Press, Johannesburg.

Bozzoli, B. (1990) 'Intellectuals, Audiences and Histories: South African Experiences, 197888', Radical History Review, no 46-47, 237-263.

Brand, C.M. (1971) 'Politics and African Trade Unionism in Rhodesia Since Federation', Rhodesian History, vol 2, 89-108. 
Brás, M.L. (2008) 'The Twists and Turns of Life', in M.V. Pereira (ed) Pathways of Feeling: Stories Told by Portuguese Women in Africa. Portuguese Women's League in South Africa, Durban, 148-160.

Brattain, M. (2001) Politics of Whiteness: Race, Workers, and Culture in the Modern South. Princeton University Press, Princeton.

Brownell, J. (2008) 'The Hole in Rhodesia's Bucket: White Emigration and the End of Settler Rule', Journal of Southern African Studies, vol 34, no 3, 591-610.

Brownell, J. (2011) The Collapse of Rhodesia: Population Demographics and the Politics of Race. I.B. Tauris, London.

Buettner, E. (2016) Europe After Empire: Decolonization, Society, and Culture. Cambridge University Press, Cambridge.

Bundy, C. (2016) Poverty in South Africa: Past and Present. Jacana, Auckland Park.

Burawoy, M. (1979) Manufacturing Consent: Changes in the Labor Process Under Monopoly Capitalism. University of Chicago Press, Chicago.

Bush, B. (2004) 'Gender and Empire: The Twentieth Century', in P. Levine (ed) Gender and Empire. Oxford University Press, Oxford, 77-111.

Butcher, J. (1979) The British in Malaya, 1880-1941: The Social History of a European Community in Colonial Southeast Asia. Oxford University Press, Oxford.

Butler, L.J. (2002) Britain and Empire: Adjusting to a Post-Imperial World. I.B. Tauris, London and New York.

Butler, L.J. (2007) Copper Empire: Mining and the Colonial State in Northern Rhodesia, c. 193064. Palgrave Macmillan, Basingstoke.

Cabaço, J.L. (2009) Moçambique: identidade, colonialismo e libertação. Editora Unesp, São Paulo.

Cabral, J. (1960) 'A Portuguese Letter', Africa South in Exile, vol 5, no 1, 60-62.

Cairnie, J. (2010) Imperialists in Broken Boots: Poor Whites and Philanthropy in Southern African Writing. Cambridge Scholars, Newcastle.

Camacho, B. (1937 [1925]) Questões Nacionais. Guimarães \& Comp. ${ }^{a}$, Lisbon.

Cândido, A. (1952) O problema dos excedentes demográficos. Imprensa Nacional, Lisbon.

Cardão, M. (2012) 'Fado Tropical: Luso-tropicalismo na cultura de massas (1960-1974)', PhD thesis, Instituto Universitário de Lisboa.

Castelo, C. (1998) O modo português de estar no mundo: O luso-tropicalismo e a ideologia colonial portuguesa, 1933-1961. Afrontamento, Porto.

Castelo, C. (2007) Passagens para a África: O povoamento de Angola e Moçambique com Naturais da Metrópole, 1920-1974. Afrontamento, Proto.

Castelo, C. (2010) 'Prefácio à presente edição', in G. Freyre (ed) Um Brasileiro em terras portuguesas. É Realizações, São Paulo, 11-29.

Castelo, C. (2012a) 'Colonial Migration to Angola and Mozambique: Constraints and Illusions', in E. Morier-Genoud and M. Cahen (eds) Imperial Migrations: Colonial Communities and Diaspora in the Portuguese World. Palgrave Macmillan, Basingstoke, 107-128.

Castelo, C. (2012b) “"O ‘branco do mato de Lisboa”: a colonização agrícola dirigida e os seus fantasmas', in C. Castelo et al. (eds) Os outros da colonização: ensaios sobre tardo-colonialismo em Moçambique. Imprensa de Ciências Sociais, Lisbon, 27-50.

Castelo, C. (2012c) 'Scientific Research and Portuguese Colonial Policy: Developments and Articulations, 1936-1974', História, Ciênca, Saúde-Manguinhos, vol 19, no 2, 391-408.

Castelo, C. et al. (2012) 'Introdução: Tardo-colonialismo e a produção de alteridades', in C. Castelo et al. (eds) Os outros da colonização: ensaios sobre tardo-colonialismo em Moçambique. Imprensa de Ciências Sociais, Lisbon, 19-24.

Castelo, C. (2014) 'Developing "Portuguese Africa" in Late Colonialism: Confronting Discourses', in J. Hodge, G. Höld and M. Kopf (eds) Developing Africa: Concepts and Practices in Twentieth-Century Colonialism. Manchester University Press, Manchester, 63-86. 


\section{Bibliography}

Castelo, C. (2016) 'Reproducing Portuguese Villages in Africa:Agricultural Science, Ideology and Empire', Journal of Southern African Studies, vol 42, no 2, 267-281.

Cavell, J. (2006) 'The Imperial Race and the Immigration Sieve: The Canadian Debate on Assisted British Migration and Empire Settlement, 1900-30', The Journal of Imperial and Commonwealth History, vol 34, no 3, 345-367.

Chabal, P. (2002) A History of Postcolonial Lusophone Africa. Hurst, London.

Chakrabarty, D. (2000) Provincializing Europe: Postcolonial Thought and Historical Difference. Princeton University Press, Princeton.

Challis, B. (1992) 'Education and Southern Rhodesia's Poor Whites, 1890-1930', in R. Morrell (ed) White but Poor: Essays on Poor Whites in Southern Africa 1880-1940. University of South Africa Press, Pretoria, 151-170.

Chichava, S.I. (2013) 'Unlike the OtherWhites? The Swiss in Mozambique Under Colonialism', in E. Morier-Genoud and M. Cahen (eds) Imperial Migrations: Migration, Diasporas and Citizenship. Palgrave Macmillan, London, 149-167.

Chisholm, L. (1989) 'Reformatories and Industrial Schools in South Africa: A Study in Class, Colour and Gender, 1882-1939', PhD thesis, University of the Witwatersrand.

Choi, S. (2016) Decolonization and the French of Algeria. Palgrave Macmillan, Basingstoke.

Clarence-Smith, W.G. (1980) 'Class Structure and Class Struggles in Angola in the 1970s', Journal of Southern African Studies, vol 7, no 1,109-126.

Clarence-Smith, W.G. (1985) The Third Portuguese Empire, 1825-1975: A Study in Economic Imperialism. Manchester University Press, Manchester.

Clements, F. (1969) Rhodesia: The Course to Collision. Pall Mall Press, London.

Cleminson, R. (2014) Catholicism, Race and Empire: Eugenics in Portugal, 1900-1950. CEU University Press, Budapest.

Coelho, C. (1973) 'Elementos Estatísticos: Moçambique', Finisterra, vol 8, no 15, 145-161.

Cohen, A. (2017) The Politics and Economics and Decolonization in Africa: The Failed Experiment of the Central African Federation. I.B. Tauris, London.

Colley, L. (1992) 'Britishness and Otherness: An Argument', Journal of British Studies, vol 31, no 4, 309-329.

Coltart, D. (2016) The Struggle Continues: 50 Years of Tyranny in Zimbabwe. Jacana, Auckland Park.

Constantine, S. (2003) 'British Emigration to the Empire-Commonwealth Since 1880: From Overseas Settlement to Diaspora?' in C. Bridge and K. Fedorowich (eds) The British World: Diaspora, Culture and Identity. Frank Cass, London, 16-35.

Cooper, F. (1996) Decolonization and African Society: The Labor Question in French and British Africa. Cambridge University Press, Cambridge.

Cooper, F. (2005) Colonialism in Question: Theory, Knowledge, History. University of California Press, Berkeley.

Cooper, F. and Packard, R. (ed) (1997) International Development and the Social Sciences: Essays on the History and Politics of Knowledge. University of California Press, Berkeley.

Cooper, F. and Stoler, A. (1989) 'Introduction: Tensions of Empire: Colonial Control and Visions of Rule', American Ethnologist, vol 16, no 4, 609-621.

Costa,A. (1911) Estudos de Economia Nacional - I: O Problema da Emigração. Imprensa Nacional, Lisbon.

Coupe, S. (1994) 'Labour Relations by Authoritarian Regimes Since 1945: South Africa in International Perspective', paper presented at Wits History Workshop, Johannesburg, 13-15 July, http://wiredspace.wits.ac.za/bitstream/handle/10539/7760/HWS-72. pdf?sequence $=1$ 
Coupe, S. (1995) 'Divisions of Labour: Racist Trade Unionism in the Iron, Steel, Engineering and Metallurgical Industries of Post-War South Africa', Journal of Southern African Studies, vol 21, no 3, 451-471.

Covane, L.A. (2001) O Trabalho Migratório e a Agricultura no Sul de Moçambique (1920-1992). Promédia, Maputo.

Crankshaw, O. (1997) Race, Class and the Changing Division of Labour Under Apartheid. Routledge, London.

Crompton, R. (1994) 'The South African Commodity Plastics Filiere: History and Future Strategy Options', PhD thesis, University of Natal.

Cunningham, S. (1981) The Copper Industry in Zambia: Foreign Mining Companies in a Developing Country. Praeger, New York.

Daveau, S. (2002) 'A obra geográfica de Mariano Feio', Finisterra, vol XXXVII, no 73, 101-107.

Davenport, T.R.H. (1977) South Africa: A Modern History. Palgrave Macmillan, Johannesburg.

Davidson, A., Filatova, I., Gorodnov, V. and Johns, S. (2014) South Africa and the Communist International: A Documentary History. Volume I. Routledge, London.

Davies, R.H. (1973) 'The White Working-Class in South Africa', New Left Review, vol 82, $40-59$.

Davies, R.H. (1980) Capital, State and White Labour in South Africa 1900-60. Harvester, Brighton.

Davies, R.H., Kaplan, D., Morris, M. and O'Meara, D. (1976) 'Class Struggles and the Periodization of the South African State', Review of African Political Economy, vol 3, no 7, 3-40.

Dias, J. (1961) Relatório da Campanha de 1960 (Angola e Moçambique). Centro de Estudos Políticos e Sociais, Lisbon.

Dixon, A.J. (1973) 'The Multiracial Myth', Zambezia, vol 3, no 1, 61-65.

Dorman, S., Hammett, D. and Nugent, P. (eds) (2007) Making Nations, Creating Strangers: States and Citizenship in Africa. Brill, Leiden.

Dousemetzis, H. and Gerry, L. (2018) The Man Who Killed Apartheid: The Life of Dimitri Tsafendas. Jacana Media, Johannesburg.

Doyle, A.C. (1981) The Penguin Complete Sherlock Holmes. Penguin, Harmondsworth.

Drew, A. (2000) Discordant Comrades: Identities and Loyalties on the South Africa Left. Ashgate, Aldershot.

Dubow, S. (1986) 'Race, Civilisation and Culture: The Elaboration of Segregation Discourse in the Inter-War Years', African Studies Seminar Paper, University of the Witwatersrand.

Dubow, S. (1995) Scientific Racism in Modern South Africa. Cambridge University Press, Cambridge.

Dubow, S. (2014) Apartheid, 1948-1994. Oxford University Press, Oxford.

Dunn, C. (1959) Central African Witness.Victor Gollancz, London.

Elkins, C. and Pederson, S. (eds) (2005) Settler Colonialism in the Twentieth Century: Projects, Practices and Legacies. Routledge, New York.

Epprecht, M. (2005) 'Black Skin, "Cowboy" Masculinity: A Genealogy of Homophobia in the African Nationalist Movement in Zimbabwe to 1983', Culture, Health and Sexuality, vol 7, no 3, 253-266.

Errante, A. (2003) 'White Skins, Many Masks: Colonial Schooling, Race and National Consciousness Among White Settler Children in Mozambique, 1934-1974', International Journal of African Historical Studies, vol 36, no 1, 7-33.

Evans, I. (1997) Bureaucracy and Race: Native Administration in South Africa. University of California Press, Berkeley. 
Ewing, A. (1982) 'Administering India: The Indian Civil Service', History Today, vol 32, no 6, 43-48.

Feinstein, C.F. (2005) An Economic History of South Africa: Conquest, Discrimination and Development. Cambridge University Press, Cambridge.

Feio, M. (1998) As Causas do Fracasso da Colonização Agrícola de Angola. Instituto de Investigação Científica Tropical, Lisbon.

Fetter, B. (1976) The Creation of Elisabethville. Hoover Institution Press, Stanford.

Fisher, J.L. (2010) Pioneers, Settlers, Aliens, Exiles: The Decolonisation of White Identity in Zimbabwe.ANU E Press, Canberra.

Fourie, J. (2006) 'The South African Poor White Problem in the Early 20th Century: Lessons for Poverty Today', Stellenbosch Economic Working Papers, 14 June.

Fraenkel, J. (2015) “"Equality of Rights for Every Civilised Man South of the Zambezi”: Electoral Engineering in Southern Rhodesia, 1957-65', Journal of Southern African Studies, vol 41, no 6,1167-1180.

Freund, B. (1992) 'Introduction: The Poor Whites: A Social Force and a Social Problem in South African History', in R. Morrell (ed) White but Poor: Essays on the History of Poor Whites in Southern Africa 1880-1940. UNISA Press, Pretoria, xiii-xxiii.

Freund, B. (2013a) 'A Ghost from the Past: The South African Developmental State of the 1940s', Transformations, no 81-82, 86-114.

Freund, B. (2013b) 'Labour Studies and Labour History in South Africa: Perspectives from the Apartheid Era and After', International Review of Social History, vol 58, no 3, 493-519.

Freund, B. (2019) Twentieth Century South Africa: A Developmental History. Cambridge University Press, Cambridge.

Freyre, G. (1933) Casa grande E Senzala: Formação da Família Brasileira sob o Regime de Economia Patriarcal. Maria e Schmidt, Rio de Janeiro.

Freyre, G. (1961) O Luso e o Trópico. Comissão Executiva das Comemorações do V Centenário da Morte do Infante D. Henrique, Lisbon.

Friedman, S. (1987) Building Tomorrow Today: African Workers in Trade Unions 1970-1984. Ravan Press, Johannesburg.

Galvanese, M.S. (2014) 'Os discursos sobre a emigração portuguesa no Pós-Segunda Guerra Mundial: a Junta da Emigração entre o proibicionismo e o avanço liberal (1947-1961)', Revista Portuguesa de História, vol 45, 393-413.

Gann, L.H. and Gelfand, M. (1964) Huggins of Rhodesia: The Man and His Country. George Allen and Unwin, London.

Ghosh, D. and Kennedy, D. (2006) Decentering Empire: Britain, India, and the Transcolonial World. Orient Longman, Hyderabad.

Giliomee, H.B. (1983) 'Constructing Afrikaner Nationalism', in H. Adam (ed) South Africa: The Limits of Reform Politics. Brill, Leiden, 83-98.

Giliomee, H.B. (2009) The Afrikaners: Biography of a People. University of Virginia Press, Charlottesville.

Giliomee, H.B. (2012) The Last Afrikaner Leaders: A Supreme Test of Power. Tafelberg, Cape Town.

Giliomee, H.B. (2013) 'Apartheid: A Complex Heritage', paper presented to the Workshop on the Economics of Apartheid, Cape Town, 20 March.

Glaser, C. (2010) 'Portuguese Immigrant History in Twentieth Century South Africa: A Preliminary Overview', African Historical Review, vol 42, no 2, 61-83.

Glaser, C. (2012) 'The Making of a Portuguese Community in South Africa, 1900-1994', in E. Morier-Genoud and M. Cahen (eds) Imperial Migrations: Colonial Communities and Diaspora in the Portuguese World. Palgrave Macmillan, Basingstoke, 213-288. 
Glaser, C. (2013) 'White but Illegal: Undocumented Madeiran Immigration to South Africa, 1920s-1970s', Immigrants \& Minorities, vol 31, no 1, 74-98.

Gonçalves, M. (2018) 'Of Peasants and Settlers: Ideas of Portugueseness, Imperial Nationalism and European Settlement in Africa, c. 1930-c.1945', European Review of History: Revue Européenne d'histoire, vol 25, no 1,166-186.

Good, K. (1974) 'Settler Colonialism in Rhodesia', African Affairs, vol 73, no 290, 10-36.

Goodrich, C. (1920) The Frontier of Control: A Study of British Workshop Politics. G. Bell \& Son, New York.

Greenberg, S. (1980) Race and State in Capitalist Development: South Africa in Comparative Perspective. Ravan Press, Johannesburg.

Greenberg, S. (1987) Legitimating the Illegitimate: State, Markets, and Resistance in South Africa. University of California Press, Berkeley.

Grimbeek, M.H. (1988) 'Vereniging van Staatsamptenare van Suid-Afrika: n Ontleding van die Doelwitte en Aktiwiteite gemik op die Daarstelling van Diens-en Ledevoordele', Unpublished MA thesis, University of South Africa.

Groves, Z. (2013) 'Transnational Networks and Regional Solidarity:The Case of the Central African Federation, 1953-1963', African Studies, vol 72, no 2, 155-175.

Grundlingh, A. (2008) “"Are We Afrikaners Getting too Rich?” Cornucopia and Change in Afrikanerdom in the 1960s', Journal of Historical Sociology, vol 21, no 2-3, 143-165.

Guglielmo, T.A. (2003) White on Arrival: Italians, Race, Color, and Power in Chicago, 1890-1945. Oxford University Press, Oxford.

Guillaume, P. and Teppo, A. (2002) 'La Privatisation du Destin: Afrikaner, pauvre et urbain dans l'Afrique du Sud post-apartheid', Politique Africaine, no 85, 123-132.

Hammond, R.J. (1967) 'Race Attitudes and Policies in Portuguese Africa in the Nineteenth and Twentieth Centuries', Race \& Class, vol 9, no 2, 205-216.

Hancock, I. and Godwin, P. (1993) Rhodesians Never Die: The Impact of War and Political Change on White Rhodesia, c.1970-1980. Oxford University Press, Oxford.

Hansen, P. and Jonsson, S. (2011) 'Demographic Colonialism: EU-African Migration Management and the Legacy of Eurafrica', Globalizations, vol 8, no 3, 261-276.

Hansen, P. and Jonsson, S. (2014) Eurafrica: The Untold History of European Integration and Colonialism. Bloomsbury, New York.

Harris, M. (1958) 'Portugal's African Wards: A First-Hand Report on Labour and Education in Moçambique', Africa Today, vol 5, no 6, 3-36.

Harrison, P. and Zack, T. (2010) 'The Wrong Side of the Mining Belt? Spatial Transformation and Identities in Johannesburg's Southern Suburbs', in Philip Harrison et al. (eds) Changing Space, Changing City; Johannesburg After Apartheid. Wits University Press, Johannesburg, 269-292.

Hartnack, A. (2015) 'Whiteness and Shades of Grey: Erasure, Amnesia and the Ethnography of Zimbabwe's Whites', Journal of Contemporary African Studies, vol 33, no 2, 285-299.

Harvey, A.D. (2006) 'Counter-Coup in Lourenco Marques: September 1974', International Journal of African Historical Studies, vol 39, no 3, 487-498.

Hazlewood, A. (1967) 'The Economics of Federation and Dissolution in Central Africa', in A. Hazlewood (ed) African Integration and Disintegration: Case Studies in Economic and Political Union. Oxford University Press, London, 185-210.

Henderson, I. (1972) 'White Populism in Southern Rhodesia in Comparative Perspective', Comparative Studies in Society and History, vol 14, no 4, 387-399.

Hepple, A. (1967) Verwoerd. Penguin, Harmondsworth.

Hermele, K. (1998) Land Struggles and Social Differentiation in Southern Mozambique: A Case Study of Chokwe, Limpopo, 1950-198. Scandinavian Institute of African Studies, Uppsala. 
Higginson, J. (2007) 'Privileging the Machines: American Engineers, Indentured Chinese and White Workers in South Africa's Deep-Level Gold Mines, 1902-1907', International Review of Social History, vol 52, no 1,1-34.

Hodder-Williams, R. (2009) 'Afrikaners in Rhodesia: A Partial Portrait', African Social Research, vol 18, 611-641.

Hodge, J.M. and Hödl, G. (2014) 'Introduction', in J.M. Hodge, G. Hödl and M. Kopf (eds) Developing Africa: Concepts and Practices in Twentieth-Century Colonialism. Manchester University Press, Manchester, 1-34.

Holleman, J.F. and Biesheuvel, S. (1960) The Attitudes of White Mining Employees Towards Life and Work on the Copperbelt. National Institute for Personnel Research, Johannesburg.

Horrell, M. (1969) South Africa's Workers: Their Organizations and the Patterns of Employment. South African Institute of Race Relations, Johannesburg.

Houghton, D.H. (1975) 'Economic Development, 1865-1958', in M.Wilson and L. Thompson (eds) The Oxford History of South Africa, Volume II: South Africa, 1870-1966. Oxford University Press, Oxford, 1-48.

Hughes, D.M. (2003) 'Fighting for White Rule in Africa: The Central African Federation, Katanga, and the Congo Crisis, 1958-1965', The International History Review, vol 25, no 3, 592-615.

Hughes, D.M. (2010) Whiteness in Zimbabwe: Race, Landscape and the Problem of Belonging. Palgrave Macmillan, New York.

Hunter, E. (2016) 'Introduction', in E. Hunter (ed) Citizenship, Belonging, and Political Community in Africa: Dialogues Between Past and Present. Ohio University Press, Athens, 1-16.

Hyam, R. and Henshaw, P. (2003) The Lion and the Springbok: Britain and South Africa Since the Boer War. Cambridge University Press, Cambridge.

Hyslop, J. (1999) 'The Imperial Working Class Makes Itself "White": White Labourism in Britain, Australia, and South Africa Before the First World War', Journal of Historical Sociology, vol 12, no 4, 398-421.

Hyslop, J. (2003) 'The White Poor at the End of Apartheid: The Collapse of the Myth of Afrikaner Community', Itinerario, vol 27, no 2-3, 226-248.

Hyslop, J. (2004) The Notorious Syndicalist. J.T. Bain: A Scottish Rebel in Colonial South Africa. Jacana, Johannesburg.

Hyslop, J. (2006) 'The World Voyage of James Keir Hardie: Indian Nationalism, Zulu Insurgency an the British Labour Diaspora, 1907-1908', Journal of Global History, vol 1,343-362.

Hyslop, J. (2010) 'Scottish Labour, Race, and Southern African Empire c.1880-1922:A Reply to Kenefick', International Review of Social History, vol 55, no 1, 63-81.

Hyslop, J. (2014) “"Undesirable Inhabitant of the Union . . Supplying Liquor to Natives": D.F. Malan and the Deportation of South Africa's British and Irish Lumpen Proletarians, 1924-1933', Kronos, vol 40, 178-197.

Hyslop, J. (2018) 'The Politics of Disembarkation: Empire, Shipping and Labor in the Port of Durban, 1897-1947', International Labor and Working Class History, vol 93, 176-200.

Jackson, W. (2011) 'Bad Blood: Poverty, Psychopathy and the Politics of Transgression in Kenya Colony, 1939-59', Journal of Imperial and Commonwealth History, vol 39, no 1, 73-94.

Jackson, W. (2013) Madness and Marginality: The Lives of Kenya's White Insane. Manchester University Press, Manchester.

Jackson, W. (2018) 'The Shame of Not Belonging: Navigating Failure in the Colonial Petition, South Africa 1910-1961', Itinerario, vol 42, no 1, 85-101.

Jerónimo, M.B. and Monteiro, J.P. (eds) (2017) Internationalism, Imperialism and the Formation of the Contemporary World. Palgrave Macmillan, Basingstoke. 
Jerónimo, M.B. and Pinto, A.C. (2015) 'A Modernizing Empire? Politics, Culture and Economy in Portuguese Late Colonialism', in M.B. Jerónimo and A.C. Pinto (eds) The Ends of European Colonial Empires: Cases and Comparisons. Palgrave Macmillan, New York and Hampshire, 51-80.

Johnstone, F.A. (1970) 'White Prosperity and White Supremacy in South Africa Today', African Affairs, vol 69, no 275, 125-140.

Johnstone, F.A. (1976) Class, Race and Gold:A Study of Class Relations and Racial Discrimination in South Africa. Routledge and Kegan Paul, London.

Joubert, D. (1972) Toe Witmense Arm Was: uit die Carnegie-verslag 1932. Tafelberg, Cape Town.

Kalaora, L. (2011) 'Madness, Corruption and Exile: On Zimbabwe's Remaining White Commercial Farms', Journal of Southern African Studies, vol 37, no 4, 747-762.

Kalinga, O. (2005) 'Independence Negotiations in Nyasaland and Northern Rhodesia', International Negotiation, no 10, 235-262.

Kapuścińki, R. (1987) Another Day of Life. Pinter, London.

Katz, E. (1974) 'White Workers' Grievances and the Industrial Colour Bar, 1902-1913', South African Journal of Economics, vol 42, no 2,127-156.

Katz, E. (1976) A Trade Union Aristocracy: A History of White Workers in the Transvaal and the General Strike of 1913. African Studies Institute, Johannesburg.

Katz, E. (1994) The White Death: Silicosis on the Witwatersrand Gold Mines, 1886-1910. Witwatersrand University Press, Johannesburg.

Kay, G. (1967) A Social Geography of Zambia: A Survey of Population Patterns in a Developing Country. University of London Press, London.

Kennedy, D. (1987) Islands of White: Settler Society and Culture in Kenya and Southern Rhodesia, 1890-1939. Duke University Press, Durham, NC.

Kenny, B. (2008) 'Servicing Modernity: White Women Shop Workers on the Rand and Changing Gendered Respectabilities, 1940s-1970s', African Studies, vol 67, no 2, 365-396.

Kirchhofer, M. (1958) 'Sasolburg OFS: Report on the New Town', South African Architectural Record, no 43, 18-35.

Koorts, L. (2013) ““The Black Peril Would Not Exist If It Were Not for a White Peril That Is a Hundred Times Greater": D.F. Malan's Fluidity on Poor Whiteism and Race in the PreApartheid Era, 1912-1939', South African Historical Journal, vol 65, no 4, 2013, 555-576.

Koorts, L. (2014) D.F. Malan en die opkoms van Afrikanernasionalisme. Tafelberg, Cape Town.

Krikler, J. (2005a) The Rand Revolt: The 1922 Insurrection and Racial Killing in South Africa. Jonathan Ball, Johannesburg and Cape Town.

Krikler, J. (2005b) White Rising: The 1922 Insurrection and Racial Killing in South Africa. Manchester University Press, Manchester.

Krikler, J. (2017) 'The Micro-History of a South African Murder', Journal of Southern African Studies, vol 46, no 6, 1255-1272.

Krikwood, D. (1984) 'Settler Wives in Southern Rhodesia: A Case Study', in H. Callan and S. Ardener (eds) The Incorporated Wife. Croom Helm, London, 143-164.

Kruger, C. (2016) '(Dis)empowered Whiteness: Un-whitely Spaces and the Production of the Good White Home', Anthropology Southern Africa, vol 39, no 1, 46-57.

Kufakurinani, U. (2015a) 'Empire and Sexual Deviance: Debating White Women's Prostitution in Early 20th Century Salisbury, Southern Rhodesia', in W. Jackson and E.J. Manktelow (eds) Subverting Empire. Palgrave Macmillan, London, 205-225.

Kufakurinani, U. (2015b) 'White Women and Domesticity in Colonial Zimbabwe, 18901980', PhD thesis, University of Zimbabwe.

Kufakurinani, U. (2019) Elasticity in Domesticity: White Women in Rhodesian Zimbabwe, 18901979. Brill, Leiden. 


\section{Bibliography}

Lake, M. and Reynolds, H. (2008) Drawing the Global Colour Line:White Men's Countries and the International Challenge of Racial Equality. Cambridge University Press, Cambridge.

Lambert, J. (2009a) 'Maintaining a British Way of Life: English-speaking South Africa's Patriotic, Cultural and Charitable Associations', Historia, vol 54, no 2, 55-76.

Lambert, J. (2009b) 'Unknown People: Reconstructing British South African Identity', Journal of Imperial and Commonwealth History, vol 37, no 4, 599-617.

Lange, L. (2003) White, Poor and Angry: White Working Class Families in Johannesburg. Ashgate, Aldershot.

Larmer, M. and Kennes, E. (2014) 'Rethinking the Katangese Secession', The Journal of Imperial and Commonwealth History, vol 42, no 4, 741-761.

Law, K. (2016a) Gendering the Settler State:White Women, Race, Liberalism and Empire in Colonial Rhodesia, 1950-1980. Routledge, New York.

Law, K. (2016b) “"Mostly We Are White and Alone": Identity, Anxiety and the Past in Some White Zimbabwean Memoirs', Journal of Historical Sociology, vol 29, no 3, 297-318.

Leal, J. (2000) Etnografias Portuguesas (1870-1970): Cultura Popular e Identidade Nacional. Publicações Dom Quixote, Lisbon.

Léonard, Y. (1994) 'Salazarisme et lusotropicalisme, histoire d'une appropriation', Lusotopie, 211-226.

Lessing, D. (1957) Going Home. Michael Joseph, London.

Lessing, D. (1968) Going Home. Panther Books, London.

Lessing, D. (2013) The Grass is Singing. Fourth Estate, London.

Lewis, J. (1984) Industrialization and Trade Union Organization in South Africa, 1924-1955: The Rise and Fall of the South African Trade and Labour Council. Cambridge University Press, Cambridge.

Leys, C. (1959) European Politics in Southern Rhodesia. Oxford University Press, Oxford.

Lichtenstein, A. (2015) “"A Measure of Democracy”: Works Committees, Black Workers, and Industrial Citizenship in South Africa, 1973-1979', South African Historical Journal, vol 67, no 2,113-138.

Lipton, M. (1986) Capitalism and Apartheid: South Africa, 1910-1986. Wildwood House, Aldershot.

Lodge, T. (2011) 'Resistance and Reform, 1973-1994', in R. Ross et al. (eds) The Cambridge History of South Africa. Cambridge University Press, Cambridge, 409-491.

Lonsdale, J. (1994) 'Moral Ethnicity and Political Tribalism', in P. Kaarsholm and J. Hultin (eds) Inventions and Boundaries: Historical and Anthropological Approaches to the Study of Ethnicity and Nationalism. International Development Studies, Roskilde, 131-150.

Lopes, M. dos S. (1968) 'Colonato do Limpopo:Aspectos sociais do povoamento', $\mathrm{PhD}$ thesis, Universdade Técnica de Lisboa, Lisbon.

Low, D. and Lonsdale, J. (1976) 'Introduction: Towards the New Order 1945-1963', in D. Low and A. Smith (eds) The Oxford History of East Africa. Oxford University Press, Oxford, $1-64$.

Lowry, D. (2007) 'The Impact of Anti-Communism on White Rhodesian Political Culture ca. 1920s-1980s', Cold War History, vol 7, no 2, 169-194.

Lowry, D. (2010) 'Rhodesia 1890-1980: The Lost Dominion', in R. Bickers (ed) Settlers and Expatriates: Britons Over the Sea. Oxford University Press, Oxford, 112-149.

Lubkemann, S.K. (2005) 'Unsettling the Metropole: Race and Reincorporation in Postcolonial Portugal', in C. Elkins and S. Pedersen (eds) Settler Colonialism in the Twentieth Century: Projects Practices and Legacies. Routledge, Abingdon, 257-270.

Lucas Phillips, C.E. (1960) The Vision Splendid: The Future of the Central African Republic. Heinemann, London. 
Lunn, J. (1997) Capital and Labour on the Rhodesian Railway System, 1888-1947. Palgrave Macmillan, London.

Lynn, M. (ed) (2006) The British Empire in the 1950s: Retreat or Revival. Palgrave Macmillan, Basin.

Mabin, A. (1986) 'Labour, Capital, Class Struggle and the Origins of Residential Segregation in Kimberley 1880-1920', Journal of Historical Geography, vol 12, no 1, 4-26.

Mabin, A. (2000) 'Varied Legacies of Modernism in Urban Planning', in G. Bridge and S. Watson (eds) A Companion to the City. Blackwell, Oxford, 555-568.

Machingaidze, V.E.M. (1980) 'The Development of Settler Capitalist Agriculture in Southern Rhodesia with Reference to the Role of the State, 1908-1939', PhD Thesis, University of London.

Manghezi,A. (2003) Trabalho forçado e cultura obrigatória do algodão: o colonato do Limpopo e o reassentamento pós-independência: c. 1895-1981. Arquivo Histórico de Moçambique, Maputo.

Mariotti, M. (2012) 'Labour Markets During Apartheid in South Africa', The Economic History Review, vol 65, no 3, 1100-1122.

Marks, S. (2011) 'Class, Culture, and Consciousness in South Africa, 1880-1899', in R. Ross et al. (eds) The Cambridge History of South Africa. Cambridge University Press, Cambridge, 102-156.

Martins, A.C. and Albina, T. (eds) (2010) Viagens e Missões Científicas nos Trópicos, 1883-2010. Instituto de Investigação Científica Tropical, Lisbon.

Mateus, D.C. and Mateus, Á. (2011) Angola 61 Guerra Colonial: Causas e Consequências. Texto, Lisbon.

Matos, N. (1926) A Província de Angola. Maranus, Porto.

Matos, P.F. (2013) The Colours of the Empire: Racialized Representations During Portuguese Colonialism. Berghahn Books, Oxford and New York.

McCulloch, J. (2000) Black Peril, White Virtue: Sexual Crime in Southern Rhodesia, 1902-1935. Indiana University Press, Bloomington, IN.

McDermott Hughes, D. (2010) Whiteness in Zimbabwe: Race, Landscape, and the Problem of Belonging. Palgrave Macmillan, New York.

Medick, H. (1987) “"Missionaries in the Row Boat?” Ethnological Ways of Knowing as a Challenge to Social History', Comparative Studies in Society and History, vol 29, no 1, 76-98.

Meeks, E.V. (2006) 'Protecting the "White Citizen Worker": Race, Labor, and Citizenship in South-Central Arizona, 1929-1945', Journal of the Southwest, vol 48, no 1, 91-113.

Meeks, E.V. (2007) Border Citizens: The Making of Indians, Mexicans, and Anglos in Arizona. University of Texas Press, Austin.

Mendes Correia, A.A. (1952) Aumento da População, Colonização, Emigração: Discurso em sessão da Assembleia Nacional em 12 de Março de 1952. Tip. Luís Marques, Lisbon.

Meneses, F.R. and McNamara, R. (2017) The White Redoubt, the Great Powers and the Struggle for Southern Africa, 1960-1980. Palgrave Macmillan, Basingstoke.

Meneses, M.P. and Gomes, C. (2013) 'Regressos? Os retornados na (des)colonização Portuguesa', in M.P. Meneses and B.S. Martins (eds) As Guerras de Libertação e os Sonhos Coloniais: Alianças Secretas, Mapas Imaginados. Almedina, Coimbra, 59-107.

Mhike, I. (2018) 'Intersections of Sexual Delinquency and Sub-normality: White Female Juvenile Delinquency in Southern Rhodesia, 1930s-c.1950', Settler Colonial Studies, vol 8, no 4, 575-593.

Middlemas, R.K. (1979) 'Twentieth Century White Society in Mozambique', Tarikh, vol 6, no 2, 30-45.

Mlambo, A.S. (1998) 'Building a White Man's Country: Aspects of White Immigration into Rhodesia Up to World War II', Zambezia, vol XXV, no ii, 124-146. 
Mlambo, A.S. (2000) 'Some Are More White Than Others": Racial Chauvinism as a Factor in Rhodesian Immigration Policy, 1890 to 1963', Zambezia, vol XXVII, no ii, 139-160.

Mlambo,A.S. (2002) White Immigration into Rhodesia: From Occupation to Federation. University of Zimbabwe Publications, Harare.

Mlambo, A.S. (2009) 'From the Second World War to UDI, 1940-1965', in B. Raftopoulos and A. Mlambo (eds) Becoming Zimbabwe: A History from the Pre-Colonial Period to 2008. Weaver Press, Harare, 65-114.

Mlambo, A.S. (2014) A History of Zimbabwe. Cambridge University Press, Cambridge.

Money, D. (2015a) “"There Are Worse Places Than Dalmuir!” Glaswegian Riveters on the Clyde and the Copperbelt', Labour History Review, vol 80, no 3, 273-292.

Money, D. (2015b) 'The World of European Labour on the Northern Rhodesian Copperbelt, 1940-1945', International Review of Social History, vol 60, no 2, 225-255.

Money, D. (2016) “"No Matter How Much or How Little They've Got, They Can't Settle Down": A Social History of Europeans on the Zambian Copperbelt, 1926-1974', PhD thesis, University of Oxford.

Monteiro, A. (n.d.) Para uma Política Imperial: Alguns discursos do Ministro das Colónias Doutor Armindo Monteiro. Agência Geral das Colónias, Lisbon.

Monteiro,A. (1933a) Directrizes duma Política Ultramarina. Agência Geral das Colónias, Lisbon.

Monteiro, A. (1933b) Os portugueses na colonização contemporânea. Agência Geral das Colónias, Lisbon.

Montgomery, D. (1993) Citizen Worker: The Experience of Workers in the United States with Democracy and the Free Market During the Nineteenth Century. Cambridge University Press, Cambridge.

Mooney, K. (1998) “"Ducktails, Flick-knives and Pugnacity”: Subcultural and Hegemonic Masculinities in South Africa 1948-1960', Journal of Southern African Studies, vol 24, no 4, 753-774.

Moreira, I. (1961) 'Aspectos económicos e sociais da obra de povoamento do vale do Limpopo', BA thesis, Instituto Superior de Agronomia, Lisbon.

Morrell, R. (ed) (1992) White but Poor: Essays on Poor Whites in Southern Africa 1880-1940. University of South Africa Press, Pretoria.

Morris, C. (1961) The Hour After Midnight: A Missionary's Experiences of Racial and Political Struggle in Northern Rhodesia. Longmans, London.

Morris, M. and Kaplan, D. (1976) 'Labour Policy in a State Corporation; A Case Study of the South African Iron and Steel Industry', South African Labour Bulletin, vol 2, no 6-7, 2-21.

Mulford, D. (1964) The Northern Rhodesia General Election 1962. Oxford University Press, Nairobi.

Munnik, A.V. (2012) 'Discursive Power and Environmental Justice in the New South Africa 1996-2005', PhD thesis, University of the Witwatersrand.

Murphy, P. (2006a) “"Government by Blackmail”: The Origins of the Central African Federation Reconsidered', in M. Lynn (ed) The British Empire in the 1950s: Retreat or Revival? Palgrave Macmillan, Basingstoke, 53-76.

Murphy, P. (2006b) “'An Intricate and Distasteful Subject”: British Planning for the Use of Force Against the European Settlers of Central Africa, 1952-65', English Historical Review, vol CXXI, no 492, 746-777.

Nascimento, J.P. (1912) A colonização do Planalto de Benguella. J. Rodrigues \& C $C^{a}$, Lisbon.

Neto, M.C. (1997) 'Ideologias, Contradições e Mistificações da Colonização de Angola no Século XX', Lusotopie, 327-359.

Nyamnjoh, F.B. (2012) 'Blinded by Sight: Divining the Future of Anthropology in Africa', Africa Spectrum, vol 47, no 2-3, 63-92. 
Olsen, S. (2009) 'Towards the Modern Man: Edwardian Boyhood in the Juvenile Periodical Press', in A.E. Gavin and A.F. Humphries (eds) Childhood in Edwardian Fiction: Worlds Enough and Time. Palgrave Macmillan, London, 159-176.

Olsen, S. (2014) 'Adolescent Empire: Moral Dangers for Boys in Britain and India, c.18001914', in H. Ellis (ed) Juvenile Delinquency and the Limits of Western Influence, 1850-2000. Palgrave Macmillan, Hampshire, 19-41.

O'Meara, D. (1983) Volkskapitalisme: Class, Capital and Ideology in the Development of Afrikaner Nationalism 1934-1983. Cambridge University Press, Cambridge.

O'Meara, D. (1993) Forty Lost Years: The Apartheid State and the Politics of the National Party, 1948-1994. Ohio University Press, Johannesburg and Athens.

Painter, N. (2002) Southern History Across the Color Line. University of North Carolina Press, Chapel Hill.

Paisley, F. (2004) 'Childhood and Race: Growing Up in Empire', in P. Levine (ed) Race and Empire. Oxford University Press, Oxford, 240-259.

Parker, J. (1972) Rhodesia: Little White Island. Pitman Publishing, London.

Parnell, S. (1992) 'Slums, Segregation and Poor Whites in Johannesburg 1920-34', in R. Morrell (ed) White but Poor: Essays on the History of Poor Whites in Southern Africa 18801940. UNISA Press, Pretoria, 115-129.

Penvenne, J.M. (1982) 'A history of African labor in Lourenco Marques, Mozambique, 1877 to 1950 ', $\mathrm{PhD}$ thesis, University of Boston.

Penvenne, J.M. (1984) 'Labor Struggles at the Port of Lourenco Marques, 1900-1933', Review (Fernand Braudel Center), vol 8, no 2, 249-285.

Penvenne, J.M. (1995) African Workers and Colonial Racism: Mozambican Strategies and Struggles in Lourenço Marques, 1877-1962. Heinemann, Portsmouth.

Penvenne, J.M. (2005) 'Settling Against the Tide: The Layered Contradictions of Twentieth Century Portuguese Settlement in Mozambique', in C. Elkins and S. Pederson (eds) Settler Colonialism in the Twentieth Century: Projects, Practices and Legacies. Routledge, NewYork, 79-91.

Pereira, R.M. (2005) 'Conhecer para Dominar: o Desenvolvimento do Conhecimento Antropolígico na Política Colonial Portuguesa em Moçambique, 1926-1959’, PhD thesis, New University of Lisbon.

Pereira, V. (2014) 'La Dictature Salazariste et le "Problème Démographique", Annales de démographie historique, vol 2, no 128, 159-186.

Perrings, C. (1979) Black Mineworkers in Central Africa: Industrial Strategies and the Evolution of an African Proletariat in the Copperbelt 1911-41. Heinemann Educational, London.

Phimister, I. (1971) 'An Emerging African Proletariat: The Shamva Mine Strike of 1927', Rhodesian History, vol 2, 65-88.

Phimister, I. (1977) 'White Miners in Historical Perspective: Southern Rhodesia 1890-1953', Journal of Southern African Studies, vol 3, no 2, 187-206.

Phimister, I. (1988) An Economic and Social History of Zimbabwe, 1890-1948: Capital Accumulation and Class Struggle. Longman, London.

Phimister, I. (1994) 'Lashers and Leviathan:The 1954 Coalminers' Strike in Colonial Zimbabwe', International Review of Social History, vol 39, no 2, 165-196.

Phimister, I. (2011) 'Workers in Wonderland? White Miners and the Northern Rhodesian Copperbelt, 1946-1962', South African Historical Journal, vol 63, no 2, 183-233.

Phimister, I. and Tembo, A. (2015) 'A Zambian Town in Colonial Zimbabwe: The 1964 "Wangi Kolia” Strike', International Review of Social History, vol 60, SI 1, 41-62.

Phimister, I. and van Onselen, C. (1997) 'The Labour Movement in Zimbabwe, 1900-1945', in B. Raftopoulos and I. Phimister (eds) Keep on Knocking: A History of the Labour Movement in Zimbabwe, 1900-1997. Baobab Books, Harare, 11-54. 
Pilossof, R. (2012) The Unbearable Whiteness of Being: Farmers' Voices from Zimbabwe. Weaver Press, Harare.

Pilossof, R. (2014) 'Reinventing Significance: Reflections on Recent Whiteness Studies in Zimbabwe', Africa Spectrum, vol 49, no 3, 135-148.

Pilossof, R. and Boersema, J. (2017) 'Not All Whites Are Farmers: Privilege, the Politics of Representation, and the Urban - Rural Divide in Zimbabwe', Africa, vol 87, no 4, 702-719.

Pimenta, FT. (2005a) 'Angola's Whites: Political Behaviour and National Identity', Portuguese Journal of Social Science, vol 4, no 3, 169-193.

Pimenta, F.T. (2005b) Brancos de Angola: Autonomismo e nacionalismo, 1900-1961. Minerva História, Coimbra.

Pimenta, F.T. (2010a) Angola: Os Brancos e a Independência. Afrontamento, Porto.

Pimenta, F.T. (2010b) 'Perspectivas da historiografia Colonial Portuguesa (Século XX)', in M.M.T. Ribeiro (ed) Outros Combates Pela História. Imprensa da Universidade de Coimbra, Coimbra, 143-158.

Pimenta, F.T. (2012) ‘Angola's Euro-African Nationalism: The United Angolan Front', in E. Morier-Genoud (ed) Sure Road? Nationalisms in Angola, Guinea-Bissau and Mozambique. Brill, Leiden and Boston, 177-197.

Pimenta, F.T. (2017) 'Colonialismo Demográfico Português em Angola: Historiografia, Identidade e Memória', Revista de Teoria da História, vol 17, no 1, 219-246.

Pirie, G. (1992) 'White Railway Labour in South Africa, 1873-1924', in R. Morrell (ed) White but Poor: Essays on the History of Poor Whites in Southern Africa 1880-1940. UNISA Press, Pretoria, 101-114.

Politakis, G. (2018) The Post-war Reconstruction of Greece: A History of Economic Stabilisation and Development, 1944-1952. Palgrave Macmillan, Athens.

Posel, D. (1984) 'Language, Legitimation and Control: The South African State After 1978', Social Dynamics: A Journal of African Studies, vol 10, no 1,1-16.

Posel, D. (1991) The Making of Apartheid: Conflict and Compromise. Oxford Clarendon Press, Oxford.

Posel, D. (1999) 'Whiteness and Power in the South African Civil Service: Paradoxes of the Apartheid State', Journal of Southern African Studies, vol 25, no 1, 99-119.

Posel, D. (2001) 'Race as Common Sense: Racial Classification in Twentieth-Century South Africa', African Studies Review, vol 44, no 2, 87-114.

Posel, D. (2011) 'The Apartheid Project, 1948-1970', in R. Ross et al. (eds) The Cambridge History of South Africa. Cambridge University Press, Cambridge, 319-368.

Potter, D.C. (1979) 'The Last of the Indian Civil Service', South Asia: Journal of South Asian Studies, vol 2, no 1-2, 19-29.

Raftopoulos, B. (1995) 'Nationalism and Labour in Salisbury, 1953-1965', Journal of Southern African Studies, vol 21, no 1, 79-93.

Ranger, T. (2010) Bulawayo Burning: The Social History of a Southern African City 1893-1960. James Currey, Woodbridge.

Rebelo, H. de S.V. (1961) Angola na África Deste Tempo: Pensamento e ação no governo da província. Self-published, Lisbon.

Ribeiro, M.F. (1890) Regras e preceitos de higiene colonial ou conselhos práticos aos colonos e emigrantes que se destinam às nossas colónias do Ultramar, 2nd edition. Ministério da Marinha e Ultramar, Lisbon.

Ribeiro, M.F. (1901) Guia higiénico do colono nas terras mais insalubres da África central. Tip. Estevão Nunes, Lisbon. 
Ribeiro, O. (1981) A colonização de Angola e o seu fracasso. Imprensa Nacional Casa da Moeda, Lisbon.

Ribeiro de Menzes, F. (2016) Salazar: A Political Biography. Enigma, New York.

Ricardo, R.P. (2014) Depoimento de Rui Pinto Ricardo. Instituto de Investigação Científica Tropical, Lisbon. Available at: https://actd.iict.pt/eserv/actd:MORPR/ACTD_Depoimento_RPR.pdf

Rodrigues, S. (1953) 'Plano de Fomento do Ultramar', Boletim Geral do Ultramar, vol XXIX, no 336-337, 55-81.

Rodrigues, S. (1956) Unidade da Nação portuguesa, Vol. 1. Agência Geral do Ultramar, Lisbon.

Roediger, D. (1991) The Wages of Whiteness: Race and the Making of the American Working Class. Verso, London.

Roediger, D. (2017) 'Who's Afraid of the White Working Class? On Joan C. Williams's "White Working Class: Overcoming Class Cluelessness in America", Los Angeles Review of Books, 17 May.

Roos, N. (2005) Ordinary Springboks, White Servicemen and Social Justice in South Africa 19391961. Ashgate, Abingdon.

Roos, N. (2011) 'Work Colonies for White Men and the Historiography of Apartheid', Social History, vol 36, no 1, 54-76.

Roos, N. (2016) 'South African History and Subaltern Historiography: Ideas for a Radical History of White Folk', International Review of Social History, vol 61, no 1,117-150.

Roque, R. (2014) 'Race and the Mobility of Humans as Things', Science, Technology, E Human Values, vol 39, no 4, 607-617.

Rosas, F. (2001) 'O salazarismo e o homem novo: ensaio sobre o Estado Novo e a questão do toralitarismo', Análise Social, vol XXXV, no 157, 1031-1054.

Rupiah, M. (1995) 'The History of the Establishment of Internment Camps and Refugee Settlements in Southern Rhodesia, 1938-1952', Zambezia, vol XXII, no ii, 137-152.

Russell, A. (2016) 'Burundi, 1960-67: Loyal Subjects and Obedient Citizens', in E. Hunter (ed) Citizenship, Belonging, and Political Community in Africa: Dialogues Between Past and Present. Ohio University Press, Athens, 101-124.

Russell, M. and Russell, M. (1979) Afrikaners of the Kalahari:White Minority in a Black State. Cambridge University Press, Cambridge.

Sadie, J.L. (2002) The Fall and Rise of the Afrikaner in the South African Economy. University of Stellenbosch Annale, Stellenbosch.

Salazar, A.O. (1945) Discursos e Notas Políticas, Vol. 2. Coimbra Editora, Coimbra.

Santa Comba (1970) 'Santa Comba, capital do povoamento, é elevada a cidade', Reordenamento, no 17, July-September.

Santos, A.A. (1945) Breves Conceitos para um Ideário de Colonização Portuguesa. Sociedade de Geografia de Lisboa, Lisbon.

Santos, J.N. (1945) Como o Colono Se Deve Preparar para a sua Viagem. Sociedade de Geografia de Lisboa, Lisbon.

Santos, P. (1954) 'Aproveitamento do Vale do Limpopo', Boletim Geral do Ultramar, vol XXX, no 352, 189-190.

Saraiva, T. (2006) 'Paisagens Tecnológicas: o domínio das águas e a colonização de Portugal e do Ultramar', presentation at the 5th Iberian Water Conference, Faro, Universidade do Algarve. Available at: https://fnca.eu/biblioteca-del-agua/directorio/file/2332-paisagenstecnologicas-o-dominio-das-aguas-e-a-colonizacao-de-portugal-e-do-ultramar.

Sardanis, A. (2003) Africa: Another Side of the Coin: Northern Rhodesia's Final Years and Zambia's Nationhood. I.B. Tauris, London. 
Saul, J.S. and Bond, P. (2014) South Africa The Present as History: From Mrs Ples to Mandela and Marikana. Jacana, Auckland Park.

Scarnecchia, T. (2011) 'The Congo Crisis, the United Nations, and Zimbabwean Nationalism, 1960-1963', African Journal on Conflict Resolution, vol 11, no 1, 63-86.

Schuermans, N. andVisser, G. (2000) 'On Poor Whites in Post-Apartheid Cities:The Case of Bloemfontein', Urban Forum, vol 16, no 4, 259-294.

Schutz, B.M. (1973) 'European Patterns, Cultural Persistence, and Political Change in Rhodesia', Canadian Journal of African Studies, vol 7, no 1, 3-26.

Schwarz, B. (2011) Memories of Empire Volume I: The White Man's World. Oxford University Press, Oxford.

Scott, J.C. (1977) The Moral Economy of the Peasant: Rebellion and Subsistence in Southeast Asia. Yale University Press, Yale.

Seekings, J. (2007) “"Not a Single White Person Should Be Allowed to Go Under”: Swartgevaar and the Origins of South Africa's Welfare State, 1924-1929', Journal of African History, vol 48, no 3, 375-394.

Seekings, J. (2008) 'The Carnegie Commission and the Backlash Against Welfare-State Building in South Africa 1931-47', Journal of South African Studies, vol 34, no 3, $515-537$.

Sharp, J. and Van Wyk, S. (2015) 'Beyond the Market: White Workers in Pretoria', in K. Hart (ed) Economy for and Against Democracy. Berghahn Books, New York, 120-136.

Shutt, A. (2015) Manners Make a Nation: Racial Etiquette in Southern Rhodesia, 1910-1963. University of Rochester Press, New York.

Shutt, A. and King, T. (2005) 'Imperial Rhodesians:The 1953 Rhodes Centenary Exhibition in Southern Rhodesia', Journal of Southern African Studies, vol 31, no 2, 357-379.

Sibanda, O. (2012) 'Social Pain and Social Death': Poor White Stigma in Post-apartheid South Africa, a Case of West Bank in East London', Anthropology Southern Africa, vol 35, no 3-4, 81-90.

Sibanda, O. (2018) 'Wounded Citizenship:The Post-colonial City and Poor Whites', Anthropology Southern Africa, vol 41, no 1, 15-24.

Silva, E. (2011) 'A propriedade e os seus sujeitos: colonização interna e colónias agrícolas durante o Estado Novo', MA thesis, Universidade Nova de Lisboa.

Smith, I. (2012) Mad Dog Killer: The Story of a Congo Mercenary. Helion \& Company, Solihull.

Soske, J. (2015) 'The Impossible Concept: Settler Liberalism, Pan-Africanism, and the Language of Non-racialism', African Historical Review, vol 47, no 2, 1-36.

South African Institute of Race Relations (1971) A Survey of Race Relations in South Africa 1970. SAIRR, Johannesburg.

South African Institute of Race Relations (1977) A Survey of Race Relations in South Africa 1976. SAIRR, Johannesburg.

South African Institute of Race Relations (1978) A Survey of Race Relations in South Africa 1977. SAIRR, Johannesburg.

Southern Rhodesia (1928) Southern Rhodesia Legislative Assembly Debates. Volume 7. Parliamentary Printers, Salisbury.

Sparks, S. (2012) 'Apartheid Modern: South Africa's Oil from Coal Project and the History of a South African Company Town', $\mathrm{PhD}$ thesis, University of Michigan.

Stassen, N. (2009) Afrikaners in Angola: 1928-1975. Protea Boekhuis, Pretoria.

Stedman Jones, G. (1971) Outcast London: A Study in the Relationship Between Classes in Victorian Society. Clarendon, Oxford.

Steele, M.C. (1970) 'White Working-class Disunity:The Southern Rhodesian Labour Party', Rhodesian History, vol 1, 59-81. 
Steyn, M. (2004) 'Rehabilitating a Whiteness Disgraced: Afrikaner White Talk in Post-apartheid South Africa', Communication Quarterly, vol 52, no 2, 143-169.

Steyn, M. (2007) 'As the Postcolonial Moment Deepens: A Response to Green, Sonn, and Matsebula', South African Journal of Psychology, vol 37, no 3, 420-424.

Stigger, P. (1992) 'Minute Substance Versus Substantial Fear:White Destitution and the Shaping of Policy in Rhodesia in the 1890s', in R. Morrell (ed) White but Poor: Essays on Poor Whites in Southern Africa 1880-1940. University of South Africa Press, Pretoria, 130-150.

St. John Wood, A. (1961) Northern Rhodesia: The Human Background. Pall Mall Press, London.

Stoler, A. (1989) 'Rethinking Colonial Categories: European Communities and the Boundaries of Rule', Comparative Studies in Society and History, vol 31, no 1, 134-161.

Stoler,A. (1995) Race and the Education of Desire: Foucault's History of Sexuality and the Colonial Order of Things. Duke University Press, Durham, NC.

Stoler, A. (1997) 'Racial Histories and Their Regimes of Truth', Political Power and Social Theory, vol 11, 182-206.

Stoler, A. (2001) 'Tense and Tender Ties: The Politics of Comparison in North American History and (Post) Colonial Studies', The Journal of American History, vol 88, no 3, 829-865.

Stoler, A. and Cooper, F. (1997) 'Between Metropole and Colony: Rethinking a Research Agenda', in A. Stoler and F. Cooper (eds) Tensions of Empire: Colonial Culture in a Bourgeois World. University of California Press, Berkeley, 1-58.

Stone, J. (1973) Colonist or Uitlander: A Study of the British Immigrant in South Africa. Oxford University Press, Oxford.

Summers, C. (2011) 'Boys, Brats and Education: Reproducing White Maturing in Colonial Zimbabwe, 1915-1935', Settler Colonial Studies, vol 1, no 1, 132-153.

Tavuyanago, B., Muguti,T. and Hlongwana, J. (2012) 'Victims of the Rhodesian Immigration Policy: Polish Refugees from the Second World War', Journal of Southern African Studies, vol 38, no 4, 951-965.

Tawse-Jollie, E. (1971) The Real Rhodesia. Books of Rhodesia, Bulawayo.

Teppo, A. (2004) 'The Making of a Good White: The Historical Ethnography of the Rehabilitation of Poor Whites in a Suburb of Cape Town', PhD thesis, University of Helsinki.

Terreblanche, S. (2012) Lost in Transformation? South Africa's Search for a New Future Since 1986. KMM Review Publishing Company, Johannesburg.

Thomaz, O.R. (2001) “"O Bom Povo Português”: Usos e Costumes d'Aquém e d'AlémMar', Maná, vol 7, no 1, 55-87.

Thomaz, O.R. (2002a) Ecos do Atlântico Sul: Representações sobre o Terceiro Império Português. Editora UFRJ, Rio de Janeiro.

Thomaz, O.R. (2002b) 'Tigres de Papel: Gilberto Freyre, Portugal e os países africanos de língua oficial portuguesa', in C. Bastos, M.V. de Almeida and B. Feldman-Bianco (eds) Trânsitos Coloniais: Diálogos Críticos Luso-Brasileiros. Imprensa de Ciências Sociais, Lisbon, 39-63.

Thompson, E.P. (2013 [1969]) The Making of the English Working Class. Penguin Books, London.

Tischler, J. (2013) Light and Power for a Multiracial Nation:The Kariba Dam Scheme in the Central African Federation. Palgrave Macmillan, Basingstoke.

Vale de Almeida, M. (2002) “Longing for Oneself”: Hybridism and Miscegenation in Colonial and Postcolonial Portugal', Etnográfica, vol 1, 181-200.

Vale de Almeida, M. (2008) 'Anthropology and Ethnology of the Portuguese-speaking Empire', in P. Poddar (ed) A Historical Companion to Postcolonial Literatures: Continental Europe and Its Empires. Edinburgh University Press, Edinburgh, 435-438.

Van der Linden, M. (2007) 'Labour History:The Old, the New and the Global', African Studies, vol 66, no 2-3, 169-180. 


\section{Bibliography}

Van der Walt, L. (2007a) 'Anarchism and Syndicalism in South Africa, 1904-1921: Rethinking the History of Labour and the Left', PhD thesis, University of the Witwatersrand.

Van der Walt, L. (2007b) 'The First Globalisation and Transnational Labour Activism in Southern Africa: White Labourism, the IWW and the ICU, 1904-1934', African Studies, vol 26, no 2-3, 223-251.

Van der Westhuizen, C. (2007) White Power and the Rise and Fall of the National Party. Zebra Press, Cape Town.

Van Onselen, C. (2001) New Babylon, New Nineveh: Everyday Life on the Witwatersrand 18861914. Jonathan Ball, Johannesburg.

Van Zyl-Hermann, D. (2014a) 'Baas or Klaas? Afrikaner Working-Class Responses to Transformation in South Africa, ca. 1977-2002', International Labor and Working-Class History, vol 86, 142-158.

Van Zyl-Hermann, D. (2014b) 'White Workers and South Africa's Democratic Transition, 1977-2011', PhD thesis, University of Cambridge.

Van Zyl-Hermann, D. and Boersema, J. (2017) 'Introduction: The Politics of Whiteness in Africa', Africa, vol 87, no 4, 651-661.

Veracini, L. (2010) Settler Colonialism: A Theoretical Overview. Palgrave Macmillan, New York.

Veracini, L. (2011) 'On Settlerness', Borderlands e-journal, vol 10, no 1, 1-17.

Veracini, L. (2013) '“Settler Colonialism”: Career of a Concept', Journal of Imperial and Commonwealth History, vol 41, no 2, 313-333.

Vincent, L. (2000) 'Bread and Honour: White Working Class Women and Afrikaner Nationalism in the 1930s', Journal of Southern African Studies, vol 26, no 1, 61-78.

Visser, C.B. (1997) 'Die Vereniging van Staatsbeamptes en die Totstandkoming van die Wet op Arbeidsverhoudinge vir die Staatsdiens, 1993 (102/1993)', Unpublished MA thesis, Potchefstroom University for Christian Higher Education.

Visser,W. (2006) 'From MWU to Solidarity: A Trade Union Reinventing Itself', South African Journal of Labour Relations, vol 30, no 2, 19-41.

Visser, W. (2013) 'A Last Desperate, but Futile, Attempt to Shore Up the Industrial Pillars of Apartheid:The Miners' Strike of 1979 and the Impact of the Wiehahn Reforms on South African Labour', Workers of the World, vol 1, no 2, 195-214.

Walker, I.L. and Weinbren, B. (1961) 2000 Casualties: A History of the South African Labour Movement. South African Trades Union Council, Johannesburg.

Watts, C. (2005) 'Killing Kith and Kin:TheViability of British Military Intervention in Rhodesia, 1964-1965', Twentieth Century British History, vol 16, no 4, 382-415.

Webster, E. (1985) Cast in a Racial Mould: Labour Process and Trade Unionism in the Foundries. Ravan Press, Johannesburg.

Welensky, R. (1964) Welensky's 4000 Days. Collins, London.

Wessels, A. (1987) Farmboy and Industrialist. Perskor, Johannesburg.

Winch, J. (2016) 'Rhodesia, Rugby and the Afrikaner: "Working Together to Send This Country Abroad"', International Journal of the History of Sport, no 33, vol 15, 1808-1825.

Witz, L. (1987) 'A Case of Schizophrenia: The Rise and Fall of the Independent Labour Party', in B. Bozzoli (ed) Class, Community and Conflict: South African Perspectives. Ravan Press, Johannesburg, 261-291.

Wolpe, H. (1976) 'The "White Working Class" in South Africa', Economy and Society, vol 5, no 2,197-240.

Worden, N. (2012) The Making of Modern South Africa: Conquest, Apartheid, Democracy. John Wiley and Sons, Chichester.

Wright, A. (2005) Tracks Across the Veldt: Memoirs of a Rhodesia Railwayman, 1950-1976. Woodfield Publishing, Bognor Regis. 
Yudelman, D. (1984) The Emergence of Modern South Africa: State, Capital, and the Incorporation of Organized Labour on the South African Gold Fields, 1902-1939. Greenwood, Westport, CT.

Zamparoni, V. (1995) 'Entre Narros \& Mulungos: Colonialismo e Paisagem Social em Lourenço Marques, c. 1890-1940', PhD thesis, University of São Paulo.

Zipp, S. (2012) Manhattan Projects: The Rise and Fall of Urban Renewal in Cold War New York. Oxford University Press, Oxford. 


\section{Index}

accidents, occupational 85

African Mineworkers' Union (AMU) 160, 166, 168

African National Congress (ANC) 92, 161

African nationalism 74

Africans see blacks

African Studies 201-202

Afrikaans 85

Afrikaner Broederbond 177, 181

Afrikaner nationalism 26, 37-38, 63, 173-174, 176, 180, 186, 189

Afrikaners: Britishness and 28, 61; citizenship in apartheid South Africa 196-198; cultural dominance 37-38; firemen's strike of 1954 140; mobility of 7; political power 31-32, 39; see also parastatal cities of the Vaal; white working class in Southern Africa, public service of apartheid South Africa

age limits, in public service $177-178$ agricultural colonisation by Portugal: in Cela, Angola 115-117, 119-122, 128-129; in Cunene, Angola 115-117, 119, 122-124, 129; historical records of 10; history of 116-118; in Limpopo, Mozambique 115-116, 119, 122-129; major enterprises of 118-128; paradoxes of 19,128-129; settlers for 9, 16-17, 38 agriculture: in South Africa 78-79, 90, 198; in Southern Rhodesia 17, 31, 46, 50-55, 62, 134-135; in Zimbabwe 7; see also settler imaginations in late colonial Mozambique

Alien Immigrants Selection Board 69 Aliens Act (1946) 67, 69

America see United States (USA) American Metal Company 157 AMU see African Mineworkers' Union (AMU)
ANC see African National Congress (ANC) Anderson, Daphne 31

Anglo American 81

Anglo-Boer War (South African War) 47, 78

Anglo-Rhodesia steel project 70

Angola: class 28; cultural dominance 38; immigrants from 74; political power 30 , 33-34; settlers from Portugal in 9, 16-17, 19, 97, 100-101, 107, 115-117, 119-124, 128-129; strikes in 6; white population in 7,36

anti-communism 34-35, 141-142

apartheid: business community 39 ; class 28 ; mineworkers 155 ; poor white problem 26; resistance to $4,162,194,202-203$; separate development 12,198-199, 202-204, 207-208, 211; see also parastatal cities of the Vaal; white workers and racial citizenship in apartheid South Africa; white working class in Southern Africa, public service of apartheid South Africa apprenticeships 37,82

Arendt, Hannah 189

artisans 30, 36-37, 51, 69, 70-73, 164

assimilation $61-67,71$

Attlee, Clement 146

Australia 32, 34, 43, 60

autonomy 158-160, 169

bailiwick concept 145

Balfour, John Aylmer 124

Ballinger, Margaret 184

Bantu Homelands Citizenship Act 198

Bantu Homelands Constitution Act 198

Barbosa, Ilídio 120

BBC 146

Beadle, Hugh 66-67, 70

Belgian Congo 6, 24, 27, 30, 35, 74, 154, 162-163 
Belgium 74, 162-163; labour from 30

Belich, James 100-101

belonging 188-190

Birmingham, David 121

birth rate 45,47

blacks: labour 146, 158-160, 166, 169, 205; in parastatal employment 85-86, 88, 90; poverty 11, 92; settlers in Mozambique 123, 124-125, 126-127; suffrage 162

black trade unions 4, 195, 196, 203-204, 208-209; see also labour legislation reforms

Boaventura, Francisco António Teixeira 120

Boer War see Anglo-Boer War (South African War)

Boléo, Oliveira 104-105

Boletim Geral das Colónias 118

bonus schemes 159

Bornman, Wessel 203, 204, 205, 207, 209

Botha, Fanie 202

Brief Concepts for an Ideal Program of Portuguese Colonisation (booklet) 118

Britain 32, 47, 155-156, 160, 196; immigrants from $33-34,36,37,59$, 62,136

Britishness 60-61, 63-64, 66-67, 69, 75, 81,147

British South Africa Company (BSAC) 44 Broederbond see Afrikaner Broederbond

Brown, E.J. 24, 25, 26

BSAC see British South Africa Company (BSAC)

Burawoy, Michael 175

business community 39, 69, 166-167, 195

Cabral, João 109

Canada 43, 60, 183

Cândido, Armando 101

capitalism 117-118, 174, 205-206, 211

Carnegie Commission 79, 81

car ownership 38

Catholic morality 103

Cela, Angola 115-117, 119-122, 128-129

censorship 128

Central African Federation: Britain and 32, 34, 63-64; growth in 137; identity 135; immigration to $18,67-69$; Northern Rhodesia 155-156, 160-161; race relations 12; Southern Rhodesia 63-64, 67-69, 135, 137, 149; strikes in 149 centralisation, in apartheid public service $177,180,181,185$

chauvinism, ethnic 60 children see state paternalism in Southern

Rhodesia; youth

"Children In Need of Care" 49-50

Children's Act (1937) 80

Children's Protection and Adoption Act

(1929) 42-43, 44, 49-50

churches 79, 88-89

Churchill, Winston 146

Church of England 51

CID see Criminal Investigation Department (CID)

cities see parastatal cities of the Vaal; urban areas

citizenship see white workers and racial citizenship in apartheid South Africa

“civilised labour" 79, 81, 183-184, 205-206

“civilising" mission 16-17, 88, 117, 128

civil service see public service

Clark, W. Marshall 176

class: "poor whites" 25-26, 28-30; settlers from Portugal 108; social mobility 29, 144; in South Africa 86-89, 173-175, 187, 189, 198, 201, 204-207, 210-211; in Southern Rhodesia 59-60, 62, 64, 73, 74-75, 144-145, 147; in white societies 1-4, 8-9, 11-14, 19-20; “white working class" 25-26, 28-30

Cold War 142

colonialism 28, 50, 99-100, 115, 118-119, 196

coloured population in South Africa 37, 79-80, 84, 90-91, 140, 144, 162, 207

Coltart, David 74

Commission of Enquiry into Protected Work 184

commodity prices 46,119

communism 34-35, 65-66, 70, 138, 140-142, 144, 149

Communist Party of Great Britain (CPGB) $65,140,141$

complicity 173, 189-190

Compulsory Education Act (1929) 46

Congo see Belgian Congo

Congress of South African Trade Unions

(COSATU) 196

consumerism 38, 186

Copperbelt, Zambia 154-155, 157-158, 168-169

copper mining 157

corporal punishment 85

COSATU see Congress of South African Trade Unions (COSATU)

Costa, Botelho da 124 
coup in Mozambique, attempted 30

CPGB see Communist Party of Great Britain (CPGB)

crime 48-49, 60, 71-72, 75, 90

Criminal Investigation Department (CID) $48,71,138,145-146$

Cripps, Lionel 47

"cultural contamination" 44, 46-49, 55-56

cultural differences $59,67,68$

cultural dominance 37-39

cultural organisations $38-39$

Cunene, Angola 115-117, 119, 122-124, 129

curfew for Africans 88

daily-paid mineworkers 158-159, 165, 169

Daily Worker 140

dams 68, 123, 124

decolonisation 99, 101, 109, 118-119, 154, 156, 168-169

Defence Act (1926) 55

defiance by whites 189-190

"degeneracy" 46, 47

De Jager, Cor 206

De Klerk, Jan 34

Delgado, Humberto 34

Delgado, Maria de Lurdes 25, 26

Department of Inland Revenue 181

Department of Labour 144

Department of Manpower 195

deportation of settlers 16, 18, 24, 59-60, 71-74, 117, 149-150; see also Taylor,

Charles Robert

Development Plans for the Overseas Provinces (Planos de Fomento para o Ultramar) 119

Dias, Jorge 105, 108-109

Diederichs, Nico 87

disabilities, white people with 184

discipline: agricultural settlers 125, 129; apartheid public service 175,181 , 183, 185, 189; firemen's strike of 1954 136-137, 145-147; state interventions 14-17; white people 3

diversity of white society $1-2,5,17-20,28$, 59-60, 115-116, 135

domesticity 45

domestic workers 89,90

Dominion Party 162

Donges, Eben 181

Doyle, Arthur Conan 154

Ducktails 38, 186

Dunn, Cyril 165

Dutch Reformed Church 79 economic crises $42,46-48,50-52,54,78$,

180, 194-195, 198, 201

economic growth 119, 137, 179, 207-209

economic integration of Southern Africa

2, 23-24

education: agricultural settlers from

Portugal 118, 127-128; in apartheid

public service 185 ; state intervention

in South Africa 80, 82-83, 92; state

paternalism in Southern Rhodesia

$42-43,46-47,50-51,55$

efficiency 182-184, 185

ELAO see European Labour Afforestation

Operations (ELAO)

elections 79, 161-162, 173

elites $11,117,173,184$

employment by parastatals $80-86,92$; see also unemployment

English 64, 70

English-speaking South Africans 28, 60, 173

entrepreneurship 67, 68, 118

Estado Novo (New State) 30, 37-38, 39,

$115,117-118,119,128-129$

ethnic chauvinism 60

etiquette 12

eugenics 48-49

Eurafrica 101

European Labour Afforestation Operations (ELAO) 52-53

exploitation, capitalist 205, 206, 211

families 42-43, 45-46, 69, 144, 159

Fanakalo language 85

Fanon, Frantz 183

farming see agriculture

Feio, Mariano 123

Ferreira,Vicente 117

Figueiredo, António de 109

firemen's strike of 1954, Southern

Rhodesia: control 147-150; discipline

13-14, 18, 136, 145-147; explanations

of strike 139-145; overview of strike 65 ,

137-139; poverty 19; racialised practices

134-136; Rhodesia Railway Workers

Union 136-137, 150; skilled workers

from Europe 8; sources for 10

"first class whites" 28

First Development Plan (Plano de Fomento) 98-99, 125

First World War 47, 138, 160

Fonseca, Moreira da 124

France 196

free marketism 39-40 
Freyre, Gilberto 28, 100, 103

Frontier of Control, The 160

gasarbeiders 203, 206, 211

gens du couleur (people of colour) 27

gold mining industry 82

Goodrich, Carter 160

government see public service; state

Grass is Singing, The 134, 145

Great Depression 42, 46, 52, 54, 78, 180 , 198, 201

Greece 67-68

Greek workers 28, 59, 67-74, 84

Group Areas Act 190

halfgeskooldes 185

Harris, Marvin 109

Hartwell, Sir Charles 165

health care $31,45,47,85$

Herstigte Nasionale Party 85

Hertzog, J.B.M. 79

hierarchy within white workforce 158, 185

Hillside Experimental Station 54

homelands 85, 198-199

home ownership 92

homosexuality 71

hostels $50,85,88$

housing 31, 80-81, 86, 92, 120, 127, 144

Huggins, Godfrey 31, 35

hypervisibility (of whites) 3

ICEM see Inter-Governmental Committee for European Migration (ICEM)

identity 8, 70, 135, 197, 200-201, 206, 209-210

illegal activities 90-91; see also crime

illegitimate white children 49

illiteracy of settlers $115,127,128$

immigration see migration

Immigration Act (1954) 63-64

immigration officials 59-60, 62-75

imperialism 135

India, independence of 63

Indian Civil Service 177, 178

Indian population: in Rhodesia 135; in

South Africa 84, 90-91, 190, 207

indocility 11-14, 90-92, 189-190

induction training programme 185-186

Industrial Conciliation Act (1924) (South Africa) 5-6, 165-166, 197

Industrial Conciliation Act (1934)

(Southern Rhodesia) 6, 136, 137, 147, 165-166
Industrial Conciliation Act (1956) (South Africa) 198, 199

industrialisation 125, 129

industrial relations 149, 157-160, 163-164, 197; see also labour legislation reforms

Industrial Schools 48, 50, 51

Industrial Tribunal 202

inequality $70,85-86$

infrastructure 99, 102, 119, 120, 122

Inter-Governmental Committee for

European Migration (ICEM) 69, 73

international experience of mineworkers 163

international politics $23-24,32-35$

interracial sex 11, 49, 71-72, 127-128, 141, 149-150

Iron and Steel Corporation of South Africa (ISCOR) 80, 81-86, 88-89, 92, 205

irrigation 122-124

ISCOR see Iron and Steel Corporation of South Africa (ISCOR)

Italy 69 ; immigrants from $59,62,67-74,84$

Jardim, Jorge 106

Jewish refugees 62

job reservation, race-based 9-10, 32, 158, 195, 198, 202-205, 207-210

juvenile delinquency $46,48-53,55$; see also youth

Kamanga, Reuben 167

Kantorowich, Roy 87

Kariba Dam 68

Katanga province, Belgian Congo 6, 24, 162-163

Kaunda, Kenneth 160

Keatley, Patrick 165

Keller, Jack 33, 65, 142, 145-146

Kenny, Noel 164

Kenya 16

Kerkorrel, Johannes 90

Keynesianism 39-40

Kirchhofer, Max 87-89

labour legislation reforms 8, 31, 194-197, 199-200, 202-211

Labour Party (Britain) 34

labour shortages 52, 83, 92, 138, 180

labour turnover 83, 136

Land Bank 54, 55

land ownership 7, 102, 129, 135

land settlement schemes 53-55, 62; see also agricultural colonisation by Portugal; 
settler imaginations in late colonial Mozambique

L'Ange, Rex 156

Lessing, Doris 68, 134, 141, 149-150

liberal views 63,74

Limpopo, Mozambique 102-106, 115-116, 119, 122-129

Lloyd, Alan D. Hutchison 64

"Luso-tropicalism" 28, 98-102, 128

Maasdorp, Gladys 34

McPherson, Jessie 34

Malan, D.F. 26, 31

Malawi Congress Party 161

Mallows, Edwin 88

manual work 54,158

marriage 45, 127-128, 144, 159

married women 45,180

masculinity 53, 71, 136-137, 141, 164

Matopos Farm School 54

Matos, Norton de 117

Mauritians 187

Maybank, Frank 34

Melo, Guilherme de 102-103

merit assessments 180-182, 188

Mesquitela, Gonçalo de 106

Mexico, labour from 201

middle class 29, 173

migration see mobility

Mine Officials and Salaried Staff Association (MOSSA) 158

Miners' Federation of Great Britain 160 mineworkers, white 7-8, 197, 202-207, 209-210; see also daily-paid mineworkers

Mineworkers' Union (MWU) 202-207, 209-210

mining industry $80,82,124,197,202$; see also white mineworkers at Zambian independence

missionaries 66

Mittal 81

mobility: of settlers $7-8,17-20,36$; in

Southern Rhodesia 60, 134, 136,

143-144, 149; three vignettes 24-26; of white mineworkers 163,169

modernisation 93, 99, 102, 103

modernity $81,86,181$

Mondlane, Eduardo 109

Monteiro, Armindo 117-118

moral conduct 50, 55, 62, 70, 74-75, 103, 117,141

moral economy 197-198, 207-210

Morrell, Robert 5, 7

MOSSA see Mine Officials and Salaried Staff Association (MOSSA)
Mozambique: class in 29; consumerism in 38 ; immigrants from $7-8,36-37,63$, 70-71, 74; Limpopo 102-106, 115-116, 119, 122-129; politics in 30,34; strikes in 6; white population in 7,36; see also settler imaginations in late colonial Mozambique

Mufulira strike of 1963 156, 157-160, 163-169

Mulder, Connie 199

multiracialism 101, 102-110

multiracial trade unions 198, 199

Mwendapole, Matthew 168

MWU see Mineworkers' Union (MWU)

Nascimento, José Pereira do 116

National Party (NP): labour relations 31, 39, 80, 198-199, 202, 209, 211; migration and 63 ; opposition to 162 ; poor white problem 5, 78; public service and 173, 176-177

National Union of Mineworkers 65, 66, 140

"neutrality", of public service 176

Newcastle, South Africa 82, 83, 84

newcomers, socialisation of 18, 135-136, 142-144, 147, 148-149, 163

New Kleinfontein strike (1913) 24

New Zealand 60

Ngwenga, Abner 126

Nieuwoudt, Attie 202, 205-207, 208

non-English-speaking whites 61, 62

non-prescribed posts 185

Northern Rhodesia 7-8, 31-34, 36-37, 39; see also white mineworkers at Zambian independence

Northern Rhodesia Mine Workers' Union (NRMWU) 158-159, 161, 163, 165-168

NP see National Party (NP)

NRMWU see Northern Rhodesia Mine Workers' Union (NRMWU)

O\&M sections see Organisation and

Methods Study (O\&M) sections

occupational adjustment scheme 183

O'Connell, Al 164

Opperman, G.O. 188

Organisation and Methods Study (O\&M) sections 183

orphanages 50, 117

otherness 200-201

Pact government, South Africa 5, 6, 31, 79 parastatal cities of the Vaal: employment by parastatals $8,80-86,92$; indocility 13 , 
90-92; planning for $81,86-89,92$; poor

white problem 9-10, 78-80, 92-93

parental control 47, 48

paternalism 85, 93; see also state paternalism

in Southern Rhodesia

patriarchy 50, 178

Paulus, Arrie 203, 207, 209

Peace Preservation Act 65, 146

pension schemes $31,79-80$

peri-urban area 91

Plano de Fomento (First Development Plan) 98-99, 125

Planos de Fomento para o Ultramar

(Development Plans for the Overseas

Provinces) 119

Polish refugees 62

politics: labour legislation reforms 203-204, 207-211; poor white problem 78-79;

"undesirable" whites 59, 65, 70, 74-75;

"white working class" 23-24, 32-35

pollution 83

poor whites in Southern Africa: approaches to 23-24; class 25-26, 28-30; cultural dominance 37-39; free marketism 39-40; global politics 2, 11, 23-24, 32-35; immigration 17, 20, 24-26, 35-37; political power 24, 30-32; racial boundaries 15, 27-28; Racial Keynesianism 39-40; see also poverty

Population Registration Act (1950) 3, 187, 198

Portugal 12, 28, 30, 39; immigrants from 7, 12, 28-29, 30, 35-39, 59, 67-74 (see also agricultural colonisation by Portugal; settler imaginations in late colonial Mozambique)

Portuguese Communist Party 34 poverty: politics and 1; poor settlers 97-98, 102-110, 115, 116, 120, 123, 126; "poor white problem" 5, 78-80, 83-84, 92-93, 173, 180, 188, 198, 205-206, 211; state paternalism and 9, 44, 46-50; "undesirable" whites 59, 61-67, 68; white workers $v s$. white poor 9-11; see also poor whites in Southern Africa

press coverage 128-129, 140

Prinsloo, Anna 24-26

privilege $3,56,70,168,169,210$

Promotion of Bantu Self-Government Act (1959) 198

propaganda $128-129$

prostitutes 71

Província de Angola, A 128

PSC see Public Service Commission (PSC) publicity material $179-180$ public service (South Africa):

Afrikanerisation 177-180; agency of officials 14, 15, 186-188; belonging 188-190; clerical jobs 178, 189; everyday race-making 186-188; general bands 177-178; historiographic frames 173-175; lower bands 182, 188; National Party and 176-177; scientific management 9, 180-186, 189; white women 10; white working class 177-180 public service (Southern Rhodesia) 45, 47, 61

Public Service Act (1923) 177-178, 182

Public Service Association 175

Public Service Commission (PSC) 174, 176-186, 189

Public Service Competitive Examination 178

quality control movement 180-181

race: citizenship and 200-202; class and 1-4, 20; employment at Iscor by 82

racial boundaries $11,15-16,27-28,63-66$, 70-71, 134-136, 142-144

racial capitalism 15, 195, 197

racial categories $11,27-28,182$, 186-188, 190

racial citizenship see white workers and racial citizenship in apartheid South Africa

racial "contamination" 44, 46-49, 55-56

racial "degeneracy" 46,47

racial hierarchies $56,78-79,104-110$, 125-128, 145, 158, 186-188, 197-200

racial identity $135,155-156$

Racial Keynesianism 39-40

racism 12-13, 86, 99, 105-109, 155-156, $168,175,187$

Railway Administration (Southern Rhodesia) 137, 138, 144

Railway African Workers Union (RAWU) 143

railways $7-8,23,33,65,69-71,80,210$; see also firemen's strike of 1954, Southern Rhodesia

Rand Revolt of 1922 5-6, 23, 32, 80, 141, 150

RAU see Rhodesia Agricultural Union (RAU)

RAWU see Railway African Workers Union (RAWU)

refugees $62,162-163$

Rego, Silva 127

rehabilitation 14-17

relief works 52-53 
removals, forced 83, 121, 126

repatriation of settlers see deportation of settlers

respectability $147-149$

Rhodes, Cecil John 44, 61, 135

Rhodesia see Northern Rhodesia; Southern Rhodesia

Rhodesia Agricultural Union (RAU) 52

Rhodesian Front 34, 60, 74, 162

Rhodesian Labour Party 31, 33-34, 37

Rhodesian Railway Review 137, 145, 146-147, 148

Rhodesian Selection Trust 157

Rhodesia Railway Workers Union (RRWU): disciplining of white workers 145-150; explanations of firemen's strike 139-145; historical records of 10 ; history of 136-137; overview of firemen's strike 138-139

Ribeiro, Manuel Ferreira 116

Ribeiro, Orlando 122, 128

right-wing conservatism 1, 34-35, 74

Rodrigues, Sarmento 98-100, 119, 123

Roediger, David 3, 200-201, 206

Rousseau, Etienne 85

RRWU see Rhodesia Railway Workers Union (RRWU)

rural areas 17, 51, 79, 90, 134-135, 177; see also agricultural colonisation by Portugal; settler imaginations in late colonial Mozambique

"rural-mindedness" 43, 50, 51, 54

Ryckmans, Pierre 35

Rzechorzek, Mieczysław “Frank” 166, 167-168

sabotage 139

SACLA see South African Confederation of Labour (SACLA)

safety, occupational 85

St Pancras home for delinquent boys 43, $50-53$

Salazar, Antonio 16, 19, 30, 99, 103, 119 , 124

SALP see South African Labour Party (SALP)

Sasol 81-82, 84-85, 92

Sasolburg 81, 85, 87-91

Schoeman, Ben 184

schools: clinics at 45 ; location of $87-88$; see also education

scientific management 158-159, 163, 169, 180-186, 189 "second-class whites" 28

Second World War 31, 55, 61-62, 118-119, $137,142,198$

segregation $28,81,88,145,173$

Selection Immigration Board 62-63, 68, 69

self-image 164, 200, 206

separate development 12, 198-199, 202-204, 207-208, 211

Settlement Boards (Juntas de Povoamento) 107

settlement schemes see land settlement schemes

Settler colonialism 97-102, 109

"settler", use of term 126

settler imaginations in late colonial

Mozambique: colonial settlerism 19,

97-102, 109; "Luso-tropicalism" 98-102;

multiracialism 101, 102-110; poor

whites 9, 16-17, 35, 97-98, 102-110;

transgression 12-13

settler-led violence 97

sheltered employment 184-185

Silva Carvalho, Agapito da 119-120

skilled workers 8, 80, 83-84, 100, 118

Slums Act (1934) 31, 80

smallholdings 90,92

Smith, Ian 34, 39

Smuts, Jan Christian 31, 36, 39, 85

social class see class

social Darwinism 48

social history 4-10

social mobility 19-20, 29, 85, 144

social problems 42-43, 91-92

social workers $79-80$

Sociedade de Geografia de Lisboa (Lisbon Geographic Society) 118

Sons of England 66

South Africa: Britain and 32-33; class

2, 12, 28-29, 39-40; communism 34; cultural dominance 37 ; mobility 36-37; Mozambique and 30, 97-98, 106, 108-110, 124; political power 30-31; racial boundaries 3, 28; Rand Revolt of 1922 5-6, 23, 32, 141, 150; social history 4-10; Southern Rhodesia and 51, 61, 63; Zambia and 155-156, 162, 163; see also apartheid; parastatal cities of the Vaal; white workers and racial citizenship in apartheid South Africa; white working class in Southern Africa, public service of apartheid South Africa

South African Communist Party 6, 24

South African Confederation of Labour (SACLA) 199-200, 202-211 
South African Consul 104

South African exceptionalism 23

South African Iron, Steel and Allied Industries Union 203, 205, 208

South African Labour Party (SALP) 31, 32-34

South African War (Anglo-Boer War) 47, 78

Southern Rhodesia: class 29; cultural dominance 37 ; labour legislation 6 ; mobility 19, 35-36; political power 31-34, 39, 161, 162-163; racial boundaries 28 ; white population in 7-8, 36; see also firemen's strike of 1954, Southern Rhodesia; state paternalism in Southern Rhodesia; "undesirable" whites in Southern Rhodesia

Soweto uprising 194

Spanish influenza 47

Springbok Legion 34

squatting 89

standards of living 42, 59-60, 137-138, 147,149

state interventions 3, 5-6, 14-17, 31, 210; see also parastatal cities of the Vaal; white working class in Southern Africa, public service of apartheid South Africa; state paternalism in Southern Rhodesia

state paternalism in Southern Rhodesia: agricultural training 50-53; child guardianship 9, 42-43, 49-50, 55-56; discipline 15; historical records of 10; history of Rhodesian white society 44-46; juvenile delinquency 46, 48-53, 55 ; racial and cultural contamination 44, 46-49, 55-56; St Pancras home for delinquent boys $43,50-53$; transgression 11-12; unemployment 46-49; youth land settlement scheme 53-55

steel industry 8,81

stereotypes 59, 104

Stevens, Alec 161

Steyn, D.J.C. 176-177

strikes: in Belgian Congo 24; in colonial regimes 196; in South Africa 5-6, 23-24, 32, 80, 141, 150, 194; in Southern Rhodesia 33; see also firemen's strike of 1954, Southern Rhodesia; white mineworkers at Zambian independence Successful Careers in Service of Your Country (brochure) 179

suffrage 162, 201

surveillance 181

syndicalism 33
Taswell, H.K.T. 163

Tawse-Jollie, Ethel 42

Taylor, Charles Robert 13-14, 19, 65-66, 138-141, 145-148, 149-150

Taylor, Frederick 180

Teixeira, Pinto 104

Thatcher, Margaret 34

theft 48-49, 72

timbermen 159-160, 163-169

Todd, Garfield 34, 65, 139, 140, 146

tourist trade 109

town planning $81,86-89,92$

townships 88,91

Trade Union Council of South Africa

(TUCSA) 199, 210

trade unions 33-35, 195-198, 203-204, 208-209; see also labour legislation reforms

training 82-83, 85, 92; see also education

transgression 11-14, 90, 106-108, 110, 173, 189-190

Trigo de Morais, António 104, 119, 123-124, 126, 128

TUCSA see Trade Union Council of South Africa (TUCSA)

turnover of labour 83, 136

UDI see Unilateral Declaration of Independence (UDI)

UFP see United Federal Party (UFP)

Umvuma School 53

Underground Officials' Association (UOA) 202

"undesirable" whites in Southern Rhodesia: assimilation 61-67, 71; Britishness 60-61, 63-64, 69, 75; class 59-60, 62, 64, 73, 74-75; as contested concept 59, 75; Greek 12, 59, 67-74; Italian 12, 59, 67-74; Portuguese 12, 59, 67-74; post-war 61-67; state interventions $9,16,18,135$

unemployment 46-49, 52-53, 55, 92, 106, 107, 194

Unilateral Declaration of Independence (UDI) 60, 74, 162

Union Minière du Haut Katanga 6

unions see trade unions

UNIP see United National Independence Party (UNIP)

United Federal Party (UFP) 161-162, 169

United National Independence Party (UNIP) 160-161

United Nations 163

United Party 85, 182 
United States (USA) 34, 37-38, 79, 105 , 157, 183, 200-201, 206

unskilled workers 116, 158, 205-206

UOA see Underground Officials'

Association (UOA)

urban Africans 195-196

urban areas $51,79,102,198$

urban planning $81,86-89,92$

USA see United States (USA)

Vaal, South Africa see parastatal cities of the Vaal

Van der Bijl, H.J. 85, 86-87

Vanderbijlpark 81, 82-88, 90-91

Vanderbijl Park Estate Company 87

Van Eck, H.J. 85

Ventura, Raul 123, 125-126

Verwoerd, Hendrik 79-80, 83, 174

VESCO 88

Victorian domesticity 45

violence 187-188, 197

volksgebondenheid (unity of the people) 176

Vorster, John 194, 208

wages $8,29,38,40,52-53,82,148-149$, 156-158, 184

Wages of Whiteness, The 200-201

Wankie Colliery 6, 141, 145

Watch Tower Society 66

Welensky, Roy 19, 31-32, 34, 144, 146, 162

welfare services $31,43-45,79-80,144$

Westminster system 176, 177

White but Poor 5, 7

white labourism 32-33, 157

white mineworkers 7-8, 197, 202-207, 209-210

white mineworkers at Zambian independence: historical records of 10 ; independence of Zambia 154-156, 160-163, 168-169; industrial strife at Mufulira mine 157-160; Mufulira strike of 1963 14, 17-18, 156, 163-169; whiteness $8,156-157$

whiteness 3, 8, 60-61, 156-157, 175, 200-201

white population in colonies $7-8,36,60$, 155

white poverty see poor whites in Southern Africa; poverty

white supremacy $43,55-56$

white terrorism 97

white women 10,31, 44, 84, 141, 158, 180 white workers and racial citizenship in apartheid South Africa: class 10, 19-20, 198, 201, 204-207, 210-211; international perspective 200-202; labour legislation reforms 8, 194-197, 199-200, 202-211; moral economy 197-198, 207-210; politics of labour legislation reforms 207-211; racial order 197-200; separate development 198-199, 202-204, 207-208, 211

white working class in Southern Africa: approaches to 23-24; citizenship in apartheid South Africa 197-198, 201, 210-211; class 25-26, 28-30; cultural dominance 37-39; free marketism 39-40; global politics 1-2, 11, 23-24, 32-35; immigration 17 , 20, 24-26, 35-37; political power 24, 30-32; public service of apartheid South Africa 173-174, 177-180, 188; racial boundaries 15, 27-28; Racial Keynesianism 39-40; white mineworkers at Zambian independence 169

Wiehahn, Nic 206-207, 209

Wiehahn Commission of Inquiry into Labour Legislation 194-197, 200, 202-211

Williams, Emrys 163, 167

women: married 45, 180; in South Africa $10,30,31,177-178,180,182$; in

Southern Rhodesia 45, 145; white 10, $31,44,84,141,158,180$

Women's Guild 144

working classes see white working class in Southern Africa

working conditions 85

World War I 47, 138, 160

World War II 31, 55, 61-62, 118-119, 137, 142, 198

youth: Ducktails 38, 186; juvenile delinquency 46, 48-53, 55; land settlement scheme 53-55; in public service 186; see also state paternalism in Southern Rhodesia

Zambia: Copperbelt 154-155, 157-158, 168-169; independence of 154, 160-163; see also Northern Rhodesia; white mineworkers at Zambian independence

Zamdela township 91

Zimbabwe 5, 7; see also Southern Rhodesia 